

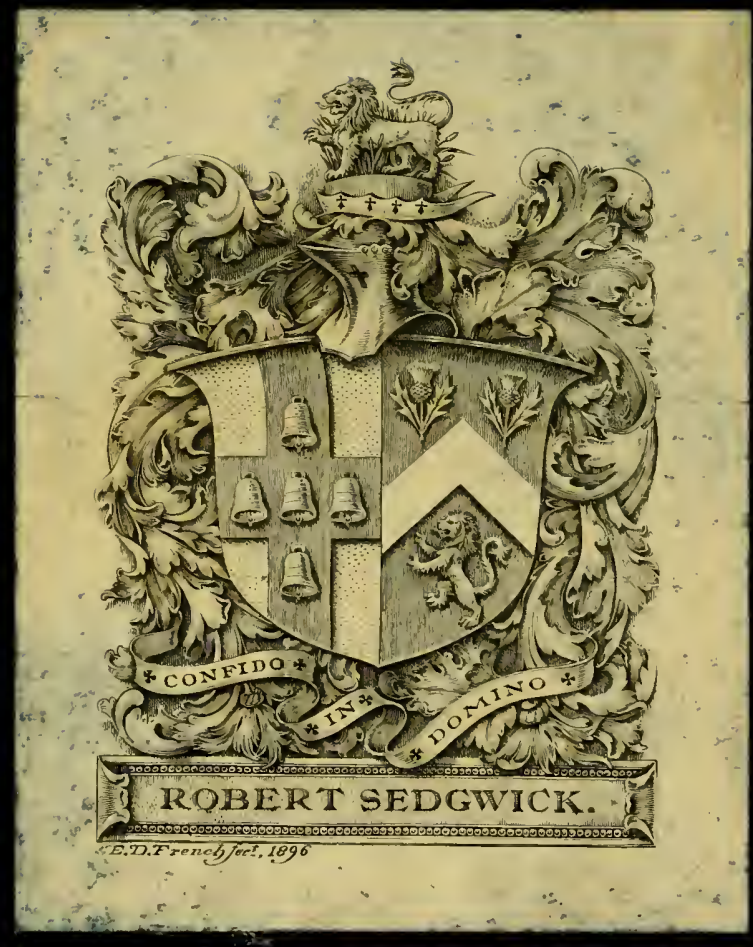




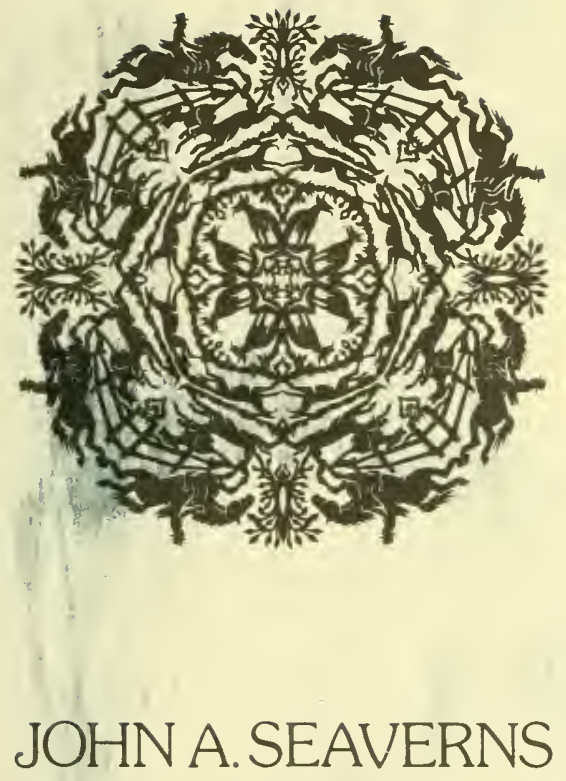





\section{HODSON OF HODSON'S HORSE}

Webster Family Lingry ne Verinany Medicine

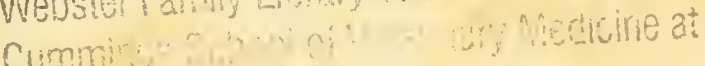

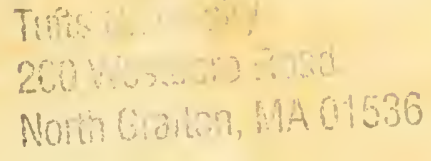


"Lightly they'll talk of the spirit that's gene, And o'er his cold ashes upbraid him;

But nothing he'll reck, if they let him sleep on In the grave where a Briton has laid him." 



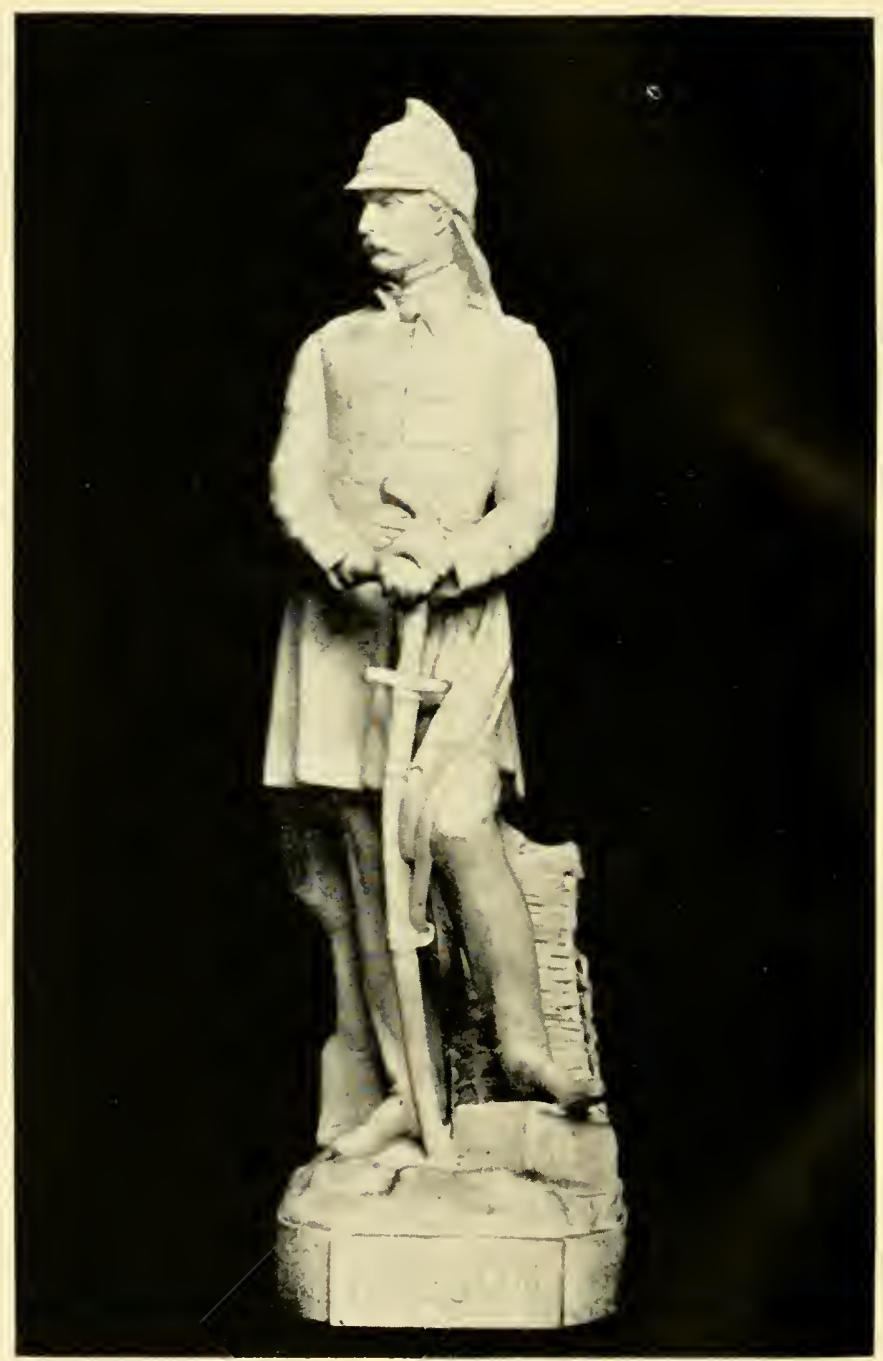

MAJOR HODSON. 


\title{
A Leader of Light Horse
}

\author{
L I F E
}

$\mathrm{OF}$

\section{HODSON OF HODSON'S HORSE}

\author{
BY \\ CAPTAIN LIONEL J. TROTTER \\ AUTHOR OF 'LIFE OF JOHN NI'HULSON, SOLDIER AND ADMIISTRATOR
}

WITH A PORTRAIT

\author{
WILLIAM BLACKWOOD AND SONS \\ EDINBURGH AND LONDON \\ M C M I
}





\section{P R E F C E.}

Among the men who fought and bled in their country's service during the flood-tide of the Indian Mutiny, few names shone with a steadier and more inspiring lustre than that of William S. R. Hodson, the prince of scouting, officers, the bold and skilful leader of Hodson's Horse. From the middle of May to the close of September 1857 the fame of his achievements rang daily louder in the field force which Barnard led from Karnâl to the siege of Delhi. During the next six months he contrived to add some new and noteworthy services to a record already blazing with heroic deeds.

Dying as a brevet-major in the prime of his strenuous manhood, he had already won for himself a proud place on the honour-lists of our long island story. Hodson's claim to be remembered as a great soldier has never been questioned even by the boldest assailants of his moral rectitude or 
of his fitness for civil rule. It was perhaps inevitable that a man of his mark and character should repel at least as many as he attracted. Few men, indeed, have had warmer friends or more persistent enemies. But the latter included none of his own household, and very few who could claim much personal knowledge of the man they misjudged.

In writing about Hodson, I have tried to steer an even course between the Scylla of unqualified praise and the Charybdis of undeserved censure. A careful study of Reynell Taylor's report, - the full text of which will be found in the Appendix, -compared with the evidence contained in some of Hodson's own letters, and in the statements volunteered by important witnesses, has convinced me that nine-tenths of the stories current to his discredit owe their prevalence and long vitality to a widespread misconception of the causes which led to his removal from the Guides. Of the remaining tenth it is enough, I think, to say that they are either absurd distortions of the truth or conclusions drawn from facts about which opinions will always differ.

In this volume I have quoted liberally from the letters published by the Rev. Prebendary George H. Hodson in his excellent biography of his illustrious brother. These letters are at once so char- 
acteristic of the writer, so full of life and movement and many-sided interests, so rich in terse and lively details of noteworthy scenes, incidents, adventures, that I think no adequate record of his romantic career could do without them. In these letters one sees the man himself in all his varied aspects and relations, from the frank, genial, sympathetic son, brother, friend, and husband, to the cool, clearheaded, resourceful soldier, always ready to do, dare, or suffer greatly in the cause of manifest duty; quick to take up with a light heart any task that good fortune or the public need might offer to his hands, and successful in winning the unbounded confidence and the loving homage of his Indian troops. Happily for my purpose, the Rev. G. H. Hodson himself invited me to make free use of his brother's published correspondence. I venture to think that no intelligent reader will grumble at my acceptance of an offer so generous, made by a master in his own field of literary art.

For much of the new matter contained in this volume my heartiest thanks are due to Miss Hodson, who supplied me with a mass of papers bearing upon her brother's career. To Hodson's old schoolfellow and lifelong friend, the Rev. F. A. Foster, I am indebted for some pleasant reminiscences of his boyhood and for several of the letters, now published for the first time. Another of his 
earliest friends, Major-General Charles Thomason, R.E., has favoured me with some happy instances of Hodson's bright, buoyant, engaging personality. To Hodson's stepson, Major-General Reveley Mitford, to Mr W. S. Seton-Karr, and Mr J. W. Sherer, C.S.I., my thanks are also due for some valuable additions to the new matter contained in this volume. The usual references to printed documents will be found in their proper places throughout the book.

L. J. T.

EAstbourne, May 1901. 


\section{O N T E N T S.}

CHAP.

PAGE

I. BJRTH AND PARENTAGE-EARLY TRAINING-SCHOOL LIFE AT RUGBY • . . . . . 1

II. FROM CAMBRIDGE TO GUERNSEY AND TORQUAY * ${ }^{*}$ -

III. THE FIRST SIKH WAR . . . . . . 20

IV. FROM SABÂTHU TO KASHMIR . . . . . 35

V. "FRESH WOODS AND PASTURES NEW" . . . 50

VI. THE OUTBREAK AT MULTÂN, AND AFTER * $\quad 61$

VII. THE SECOND SIKH WAR.$\quad$ * $\quad . \quad$. 77

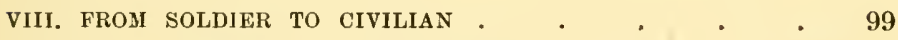

IX. FROM KASHMIR TO KUSSOWLIE * * * . 113

X. MARRIAGE AND PROMOTION TO THE COMMAND OF THE GUIDES . . . . . . . 128

XI, UNDER A CLOUD . . . . . . . . 151

XII. WAITING FOR BETTER TIMES . . . . . 171

XII. THE GREAT MUTINY-FIRST WEEKS OF THE SIEGE

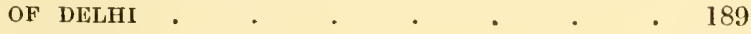

XIV. THE SIEGE OF DELHI . $\quad . \quad$. $\quad . \quad 215$

XV. BEFORE DELHI . . . . . . . 236

XVI. THE STORMING OF DELII . . . . . . . 254

XVII. FROM DELHI TO UMBÂLA . $\quad$ - . $\quad$. $\quad 276$ 
xii

CONTENTS.

XVIII. FROM UMBÂLA TO FATHIGARH . . . $\quad$. 291

XIX. FROM FATHIGARH TO CAWNPORE . . . . 308

XX. LAST SCENE OF ALL . . . . . . . . 323

XXI. CONCLUSION

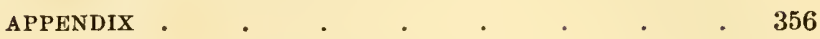

INDEX $\quad . \quad$. $\quad . \quad$. $\quad . \quad 391$ 


\section{MAJOR W. HODSON.}

CHAPTER I.

\section{BIRTH AND PARENTAGE-EARLY TRAINING-} SCHOOL LIFE AT RUGBY. 1821-1840.

William Stephen Ratkes Hodson, the subject of this memoir, was born on the 19th of March 1821 at Maisemore Court, in a village near the Severn, about two miles to the north of Gloucester. In a family of eight children, he was the third son of the Rev. George Hodson, afterwards Archdeacon of Stafford and Canon of Lichfield, who was then residing at Maisemore Court in order to be near the Bishop of Gloucester, to whom he was chaplain, and taking private pupils. The Rev. George Hodson's mother, Miss Hewitt, was sister-in-law to Archdeacon Paley, the well-known author of 'Evidences of Christianity.'

William Hodson's father came of a family which had long been settled in the north of England. The father himself had entered Trinity College, Cambridge, where he took his degree in 1810 as seventh Wrangler and second Chancellor's Medallist. 
He was shortly afterwards elected as Fellow and Tutor of Magdalen College. He married Mary Stephen, niece of James Stephen, the eminent Master in Chancery, the friend of Wilberforce and Macaulay, and the head of a family conspicuous throughout the century at the Bar, on the Bench, in Council, and in various fields of literary achievement.

Young Master Willie was blessed with a bright and joyous nature and an affectionate disposition, which endeared him not only to his own family but to all around him of whatever degree. "That which characterised him most," writes his elder brother, the Rev. George H. Hodson, "was his quickness of observation and his interest in everything going on about him. By living with his eyes and ears open, and never suffering anything to escape his notice, he acquired a stock of practical knowledge which he turned to good account in his after-life." 1 With his frank blue eyes, shapely features, his yellow hair and slim wellknit figure, he must have been a beautiful as well as a charming boy. No wonder that, in the words of Miss Sibella Hodson, "his father was wrapped up in him, and we all thought him fascinating." If his manner as a boy towards other boys was sometimes rough and masterful, he had ever a soft place in his heart for girls and women. His mother, at any rate, was not afraid to entrust him at need with the sole companionship of her youngest daughter, a trust which he never failed tenderly and loyally to fulfil.

1 Hodson of Hodson's Horse. By the Rev. George H. Hodson, M.A., \&c. Revised edition. 1889. 
"He was always," writes Miss Hodson, "very neat and tidy in his dress and appearance, and he was very handy. His handwriting, too, was always clear and beautiful; never a blot or erasure, even in the stress of active service. . . . Owing to the severe headaches from which he suffered, and which made study often hard work for him, and kept him at times from school, I used to be his playfellow," an arrangement which she never found cause to regret, even when her playmate insisted on teaching her the broadsword exercise.

During William's early boyhood his studies, on account of the headaches aforesaid, were pursued at home under the direction of his excellent father, except for the short period when the Rev. E. Harland acted as his private tutor. "Home life, however," says Mr George H. Hodson, "had not prevented him from growing up an active high-spirited boy, full of life and energy." Nor had his peculiar ailments prevented his nimble intellect from imbibing a fair amount of such knowledge as boys of his age are expected to acquire. Whatever else the boy of fourteen may have failed to learn, he had at least received the spiritual training of a nature nutritr faustis sub penetralibus - a nature fed upon the best traditions of a pure English home.

In the early part of 1837 young Hodson was sent to school at Rugby, then famous for the reforming rule of its headmaster, the wise and learned Dr Arnold, whose name has long been a household word with all readers of 'Tom Brown's School-days,' and the Life by Dean Stanley. And here I cannot do better than quote the following pertinent memoranda which have been kindly furnished me by 
Hodson's schoolfellow, Mr W. S. Seton-Karr, sometime judge in the High Court of Calcutta, and afterwards Foreign Secretary to the Government of India in 1868-69:-

"Hodson, when he came to Rugby, was older than any of his contemporaries of that year; most of them were of the age of twelve to fourteen. $\mathrm{He}$ was placed in the Middle Fifth, and thus escaped fagging altogether, and passing through the Fifth Form and the 'Twenty,' as it was then termed, reached the Sixth Form under Arnold during 1839 and 1840. Hodson was not a deep or brilliant scholar, and he was no proficient in Latin verse, on which Arnold, after some hesitation, had by that time begun to set a high value, as may be seen in Dean Stanley's Biography. But he had read the best Greek and Latin authors, and his construing was correct and even elegant; while in general knowledge of the world he always struck us as superior to the average of clever scholars of the same age. He had a store of anecdotes about public men, the universities, and their Dons; and we used to look to him more than to other contemporaries for information and enlightenment on matters beyond the reach and range of average schoolboy life.

"Hodson was no cricketer, and never eren in the Twenty-two; but he was an excellent runner, and led the others at hare-and-hounds, or paper chases, which came off at least once a-week in the winter and spring, when the claims of football were not paramount. His wind and endurance in the Crick and the Barby Hill runs were often the admiration and envy of the school. 
"Although athletics - with the exception of cricket, football, and 'Bigside-leaping' - were not so extensively practised, nor held in the same esteem, as they are at the present day, Hodson was one of the committee for converting the island into a sort of gymnasium, with swings, parallel bars, and other mechanical contrivances; and he won great renown by winning a single wager which depended on three distinct events :-

1. He was to run eight miles in the hour.

2. To run a mile in five minutes.

3. To pick up 100 stones, placed one yard apart, within the hour.

If he failed in any one of these feats he was to forfeit his stake. He accomplished them on the Tuesday, Thursday, and Saturday, half-holidays, in one week.

"I witnessed the performance on two occasions. The eight miles were run on the Barby Road, and part of the way against a cold head wind. He had some minutes to spare, and did the eight miles with hardly a pause.

"I was not present when he ran the mile, but I understood that he was ten or fifteen seconds within time. On the third occasion the stones were laid in the Close, along the path which leads from the head-master's garden to what was then the Rev. C. A. Anstey's. The event came off after 3 P.M. 'calling over,' before a crowd of boys, and I distinctly remember our tutor, Bonamy Price, looking on with wonder and approval. Hodson began by picking up all the distant stones first; and occasionally took a few between twenty and thirty yards from the starting-point. He kept 
the half-dozen nearest to the starting-point for the last, and picked them up rapidly, winning his wager with several minutes to spare.

"Doubtless, in the present day, the above record has been beaten, and the same number of stones has been picked up in three-quarters of an hour, and even less, by those whom $\mathrm{Dr}$ Arnold might have designated as fortemque Gyan, fortemque Cloconthum. But Hodson's feat, in the 'Thirties, was thought a great achievement.

"Hodson was a good disciplinarian, and could keep the fags in order. At the end of 1839 it happened that the captain, or head of Cotton's house, was unequal to the task of ruling some rather overgrown fellows who were in the Lower Forms. So, after due consultation, Arnold resolved on transferring Hodson from Price's to Cotton's house with this master's approval. The 'Doctor' always set a value on physical strength and determination as useful adjuncts to scholarship, and he was well aware of the importance of 'muscular' Christianity' in its proper place, in support of brains. Hodson's friends and colleagues at Price's were sorry to lose him; but there was no more trouble or turbulence at Cotton's when Hodson had cleared the way. I left Rugby at Midsummer 1840, while Hodson stayed till 'Lawrence Sheriff,' or Founder's day, in October."

The under-master with whom young Hodson first resided was the Rev. Bonamy Price, who had been one of Mr Hodson's pupils at Maisemore Court. Among William Hodson's younger schoolfellows was another boy, who afterwards became a distinguished member of the Indian Civil Service, Mr 
John Walter Sherer, C.S.I., who has favoured me with some pleasant reminiscences of his former schoolfellow, which illustrates the subject of them from another point of view :-

"I was at Rugby with William, but did not at first know him; he was two or three years older than myself, for one thing. . . The prepositor in my house (Powlett's, afterwards Cotton's) was F. Gell (afterwards Bishop of Madras), and when he went to Cambridge, Hodson was induced to migrate to us. I being in a Form not above fagging, became principal fag to Hodson, and had to clean his study, make his coffee, and boil his eggs. Of course he was in the Sixth, where it became an honour to have studied under Arnold. Willie Hodson used to refer to his pupilage with pride. But he was never really an Arnold man-I mean as was Stanley (Dean of Westminster), Tom Hughes, or Seton-Karr. He was rather an isolated boy; for though a great athlete, he did not play much at cricket or football, and was rather given to hare-and-hounds, long runs in the country, jumps over hedges, and so on. Occasionally he gave an exhibition in the Close (our 'playing-field') of picking up stones at distances within a certain time. He went in for dumb-bells and other contrivances for strengthening the figure, and he was a very powerful well-shaped youth. Tall rather than otherwise, with a fresh though rather pale face and yellow hair, and large dark-grey or dark-blue eyes, which were a little stern and unforgiving in expression.

"He was always rather bothered with heat, and required water for his head; and quite early would be at the pump half stripped and sousing his yellow 
locks. He was not popular, perhaps-because, being fond of long runs, he followed in a measure his own fancies. He was known to be clever and fond of reading, but took no prizes. As a fag's master he was strict, but took his fag's part, and was not unreasonable.

"We stayed on at Rugby till I ceased to be a fag and came to know him as a friend; and after I left, and he had gone to college, we met at times at Leamington."

Another schoolfellow, Mr Thomas Arnold, has also written of William Hodson in his 'Passages from a Wandering Life': “Hodson of Hodson's Horse, who boarded at Price's house, was in the Sixth Form at the same time with me. He had a remarkable face, his complexion being smooth and brilliant as that of a girl, while his hair was of a bright golden yellow. He was tall and well made, and a first-rate runner: if I remember right he was regarded as the best runner in the school. His expansive and impulsive nature won him many friends, and for my own part I always liked him greatly. His fanlts were arrogance, rashness, and a domineering temper; and if one bears this in mind, it is easy to understand the errors into which he fell in India."

How far Hodson's health interfered at times with his regular school work may be gathered from a letter written to his father by Dr Arnold in December 1839: "My report of your son's progress has been completely deranged by the state of his health, which not only hindered him from doing anything at all at his examination, but prevented him from doing his regular compositions during a great part of the 
half year, and affected, I have no doubt, his work generally. There was a peculiar inconvenience in this, because as exercise was recommended to him strongly, he took an active part in all the school amusements, so that his health seemed to interfere with nothing but his work; and though I have not the slightest doubt that the case was really so,that he could not read or compose, and that it did him good to play at football,-yet the example to the school was very apt to be misunderstood, and I think that you will agree with me that it would be better for him not to return to Rugby till his health is fully re-established. I say this, hoping most sincerely that he may be well enough to return immediately after the holidays; for what I saw of his conduct last half year in one or two important instances pleased me much, and I think that his character and influence would act more and more beneficially on the school with every half year of added age."

On the strength of this letter young Hodson's Christmas holidays were extended into the spring of 1840. On his return to Rugby he took up the post which Arnold had already designed for him, in the house of a new master, the Rev. G. E. Cotton, afterwards Bishop of Calcutta. How loyally he discharged the duties of his new and somewhat trying office the following letter from Bishop Cotton will show :-

“May 18, 1858.

"You are aware that your brother was my pupil at Rugby for a very short time. He was originally at Price's house, but at the beginning of 1840 I succeeded to a house in which there were no pre- 
positors. To remedy this want Dr Arnold arranged, with Price's consent, that your brother should be transferred to my house, partly because from my intimacy with you at Cambridge I had naturally made his acquaintance, and partly because from his energetic character and practical ability he was likely to give efficient help to a new master beginning the management of a house.

"Unfortunately at the time that he ought to have joined me he was taken ill, and did not return to Rugby till a large portion of the half year was past, and as he left it for Cambridge in the following October my immediate connection with him was brief. But it was long enough to give abundant proof that Arnold's choice had been a wise one. I remember quite well that soon after he came he made several sensible suggestions as to the arrangements of the house, which after two months or more of freedom from the authority of the Sixth had probably become somewhat anarchical. But the great point to be noticed was, that though he immediately re-established the shattered prestige of prepositorial power, he contrived to make himself very popular with various classes of boys. The younger boys found in him an efficient protector against bullying. Those of a more literary turn (amongst others one of the present Professors at Oxford) found in him an agreeable and intelligent companion, and were proud of being admitted to sit in his study and talk on matters of intellectual interest. Those who were anxious that their house should take a good position in the school were glad to see a leading member of the Sixth Form at its head, and helping it to rise to greater importance. The Democrats got their 
master, and submitted with a good grace to power which they could not resist, and which was judiciously and moderately exercised. The régime was wise, firm, and kind, and the house was happy and prosperous. In my private relations with him I always found him very pleasant, and quite able to reconcile with real tact his position as a private friend with his relation as the highest pupil and head of the house to a young master entering on his work. From all that I knew of him, both at Rugby and afterwards, I was not surprised at the courage and coolness which the 'Times' compared to 'the spirit of a paladin of old.' I cannot say how much I regret that I shall not be welcomed in India by the first head of my dear old home at Rugby."

In June 1840 Dr Arnold writes again to Hodson's father to express his entire satisfaction with the good results which had followed Hodson's return to Rugby. "I sincerely hope," he adds, "that he will be able to return to us again after the holidays."

" "Who does not remember,' says a writer in the 'Book of Rugby School,' 'the fair-haired, light-complexioned, active man, whose running feats, whether in the open fields or on the gravel walks of the Close, created such marvel among his contemporaries? He has carried his hare-and-hounds into his country's service, and as commandant of the gallant corps of Guides has displayed an activity and courage on the wild frontier of the Punjab, the natural development of his early prowess at Crick and Brownsover.' One of Hodson's schoolfellows, the future author of 'Tom Brown's School-days,' tells us how at the first calling over he used to come in splashed and hot, with his cheery, 'Old 
fellow! I've been to Brinklow since dinner.' From the same writer we learn 'that as a boy he was not remarkable for physical strength or courage, and none of us would have foretold that he would become one of the most daring and successful swordsmen in the Indian army." " 1

The sort of courage for which William Hodson was not remarkable may be inferred from the following passage in a letter addressed to me by another old Rugbeian, who afterwards won his laurels in the Indian Civil Service. "I recollect," says my informant, "that some years ago, when Tom Hughes, the author of 'Tom Brown's School-days,' was staying with me here for a few days, we had a good deal of talk about William Hodson, among other of our contemporaries at Rugby. I then found that Tom Hughes, like myself, had been a good deal surprised at the reputation which Hodson had achieved as a gallant and dashing soldier. The impression which both of us had formed of him as a schoolboy had not at all prepared us for the feats which he accomplished in after-life. We could neither of us call to mind having ever seen him in the thick of a scrimmage at football. He was generally hovering outside on these occasions, looking out probably for the chance of running with the ball."

It seems clear that Hodson's courage was naturally cool and circumspect-the courage, let us say, of Ulysses rather than the headlong fury of Ajax or Achilles. Having no great love of fighting for fighting's sake, he never threw himself into the rough-and-tumble of a football scrimmage; nor did 1 'Eraser's Magazine,' February 1859. 
his soul yearn for the joy of shedding or losing blood in hard disfiguring duels with the clenched fist.

From other accounts it appears that "larky Prichard," ${ }^{1}$ as he was called, would lead the way in a game of hare-and-hounds, "with his nice easy stride, for he never had any great pace, ${ }^{2}$ though he could last for ever, and would get back coolly and comfortably to 'Bons' when the rear hounds were toiling a mile behind." It will be seen that on the question of pace opinions appear to differ, but it is certain at least that Hodson was endowed with marvellous staying power.

In some of his holiday rambles about the pretty Staffordshire village of Colwich, where his father was then vicar, Hodson was accompanied by his friend and schoolfellow Fred. Foster, afterwards the Rev. F. A. Foster, with whom Hodson was to keep up an intimate correspondence during his Indian career. On one of these occasions the two young athletes set out on a three days' walk in Staffordshire and Derbyshire.

"So far as my memory serves me," writes Mr Foster, "we went to Matlock Bath, as we certainly did to Ashbourne and Dovedale. I well remember at the latter place, as we came down a steep slope to our quarters for the night, at the little inn, the Isaac Walton, we laughed together at our many tumbles! Certainly God took care of us, for on visiting the spot in the morning we agreed that 1 "He was called by us Prichard," writes Mr Seton-Karr, "because he came to Price's after a boy named Prichard had just left, who resembled Hodson only in the colour of his red hair."

2 "He could run at any rate one mile in five minutes," says Mr Seton-Karr. 
we should scarcely like to come down it in broad daylight.

"One morning we missed our way, and found that we had walked just twenty miles before breakfast. We asked the waiter at the hotel what he could give us for our breakfast. He mentioned a long list of various eatables, and I was amused by Hodson quietly saying, "Very well, bring them all in.'

"Our longest walk, of quite fifty miles, was on a Saturday, and about 11 P.M. I said to Hodson, 'I very much fear your father,' the Archdeacon of Stafford, with whom I was staying, 'will sit up in his study till he sees us, and we are within an hour of Sunday morning.' So we agreed to run, and did so at full speed for the last six miles, being in capital condition, and found when we reached Colwich Vicarage that the good old archdeacon was in his study awaiting our arrival."

With this feat of youthful endurance the present chapter may come to a fitting close. The evidence here collected will serve at least to show what sort of character W. Hodson left behind him when he quitted Rugby for Cambridge in the autumn of 1840. 


\section{CHAPTER II.}

FROM CAMBRIDGE TO GUERNSEY AYD TORQUAY.

$1840-1845$.

Is October 1840 William Hodson entered on his first term of residence at Trinity College, Cambridge, where his second brother, afterwards the Rev. George H. Hodson, Fellow of Trinity and Vicar of Enfield, had taken his degree a few months earlier. "Here," says the Rev. G. H. Hodson, "as might have been expected from his previous habits, he took an active interest in boating and other athletic amusements, while at the same time he by no means neglected the more serious and intellectual pursuits of the university. $\mathrm{He}$ had a very considerable acquaintance with, and taste for, both classical and general literature; but a constitutional tendency to headache very much stood in the way of any close application to books, and after he had taken his degree in 1844, was one strong reason for his deciding on an active rather than a studious life."

The new undergraduate had for his tutor the Rev. J. W. Blakesley, a Fellow of Trinity and afterwards Dean of Lincoln, who was soon to

${ }^{1}$ Hodson of Hodson's Horse. 
make his mark among scholarly English exponents of Greek and Latin classics. IVriting on March 31, 1841, to Hodson's father, Mr Blakesley takes occasion to express "the pleasure which I received from hearing that, although not successful in his late contest for the Bull Scholarship, he was among the very first of the candidates, and produced a very stroug impression in his favour.

"From the opportunities I have had of forming a judgment as to his attainments, I feel that his friends will be quite justified in expecting from him, should his health (as I trust it will) hold, a distinguished university career ; and I have, moreover, no fear that in his case, as sometimes unfortunately happens, intellectual attainments will be unaccompanied by moral habits."

One of Hodson's college friends was $\mathrm{Mr}$ G. Chance, afterwards a police magistrate in London, who has kindly favoured me with a few reminiscences of Hodson's life at Cambridge.

"It seems only a few years," he writes, "since we were at Cambridge together. He was a genial and excellent companion, and beloved by his friends. He was a member of the 2nd Trinity Boat Club, and pulled, I think, No. 3 in the first boat, of which I was stroke. He and I on one occasion rowed a pair-oar match against his cousin William Atkinson and the late Sir M. Thompson, chairman of the Midland Railway Company, in which we won. He was remarkable for his activity: some of us used to scour the country, leaping gates and ditches, and in these feats of agility he and F. Strickland, another Rugbeian, were pre-eminent. I in common with every one else followed his splendid achievements 
in India with admiration, and I would have gladly welcomed him home had he been spared."

It was about this time that William Hodson became acquainted with two boys, the sons of his father's old pupil James Thomason, who was already coming to the front in the Civil Service of the East India Company. The boys were spending their holidays under the archdeacon's hospitable roof at Colwich.

"And happy holidays they were," writes General Charles Thomason, the younger of the two sons. "It was there in the early 'Forties that I made the acquaintance of William Hodson, who speedily raised himself to the rank of hero in my boyish imagination. He was always so cheery that no boy could have resisted him.

"He enjoyed above all things coaching me up in gleanings from 'Pickwick,' which at his call I occasionally recited to an admiring audience. 'Away with melancholy, as the little boy said when his schoolmistress died,' was a favourite one, and knowing him as well in after-years as I did, I often thought of 'away with melancholy' as his natural motto. It was in the Mutiny days that we were destined to meet again." 1

It appears that during his residence at Cambridge Hodson had at one time thought of studying for the Bar. But the state of his health conspired with his earlier predilections to turn his thoughts into less pacific channels. A cadetship in the East India Company's service offered many attractions to young men of soldierly instincts and moderate wealth. It meant, for one thing, a sure provision 1 MIS. Reminiscences by General C. Thomason. 
for life, with the prospect of liberal rewards for tried capacity in various fields. There was, of course, a fixed age-limit to all such appointments, and that limit Hodson had nearly overstepped when he took his B.A. degree in the spring of 1844. He might still, however, attain his heart's desire by passing through the doorway of a militia regiment.

Through the timely intervention of Lord de Saumarez his friends obtained for him a commission in the Guernsey Militia from General Sir William Napier, then Lieutenant-Governor of Guernsey. "From the first," writes Mr G. H. Hodson, "he felt that the profession of a soldier was one that required to be studied, and took every opportunity of mastering its principles." To that end, indeed, he could hardly have studied under a worthier teacher than the great historian of the Peninsular War.

On leaving Guernsey in the winter of 1844 Hodson took with him the following testimonial from Sir William Napier: "I not only consider you fit to hold a commission in any service, but I think you will be an acquisition to any service. Your education, your ability, your zeal to make yourself acquainted with military matters, gave me the greatest satisfaction during your service in the militia, and I heartily wish you success in your present application." General Napier also gave the young soldier a commendatory letter to his brother Sir Charles, who was now strenuously governing the province which his arms had lately wrested from the Amirs of Sind. ${ }^{1}$ How little

1 The victories of Miâni and Haidarabad in 1843 had settled the 
use Hodson made of this letter we shall see byand-by.

On his return to England Hodson duly presented himself at the old India House in Leadenhall Street to take the oath of allegiance to his new masters, and see himself enrolled as a cadet of infantry on the Bengal establishment. This cadetship he had just obtained through the good offices of his father's friend, Sir Robert Inglis, who gave young Hodson the preference over a younger candidate nearly related to himself. "The fact," he wrote, "that my cousin was sixteen, and that your son was twenty-three, decided me; the one could wait, the other could not; and now that we have had the great gratification of seeing your son, I am more than ever satisfied. Lady Inglis and myself concur in thinking most favourably of his appearance and manner, and augur all things good in reference to his future life."

He then hastened to join his family at Torquay, whither they had gone for a time on account of his mother's failing health. After some happy weeks spent among his own people, amidst the wooded hills and green pastures that border the white beaches and blue seas of South Devon, he proceeded in company with his brother George to Southampton, where he embarked on board the Seringapatam, the ship that was to bear him round the Cape, to the scene of his future achievements and early death.

fate of Sind, and Sir Charles Napier became governor of the province which he had virtually conquered. 


\section{CHAPTER III.}

THE FIRST SIKH WAR. 1845-1846.

AfTER a somewhat stormy voyage of about three months, remarkable chiefly for the death of his favourite little $\operatorname{dog},{ }^{1}$ and utilised by himself in the reading of many books and gaining some little knowledge of Hindustani, William Hodson landed at Calcutta on August 20, 1845. At Madras a few weeks earlier he had been kindly received by the Governor and his family, with whom he spent some pleasant days, in spite of the weather and a touch of illness. "It is hot enough, certainly," he writes home; "but this house is delightful, and the people very kind. Their house being full, I sleep in a large tent pitched on the lawn or compound outside, which is both pleasant and cool." He was "much disappointed with the natives. I fancied them a much finer race. At a distance they are picturesque enough, but they are not contrived for a near view."

The climate of Calcutta he found "very trying: hot rains and close stifling weather, which reduces one's strength terribly." Sir Lawrence Peel, Arch-

1 The poor little creature had been shut up during a gale, and afterwards fell into convulsions from excess of joy at seeing its master again. 



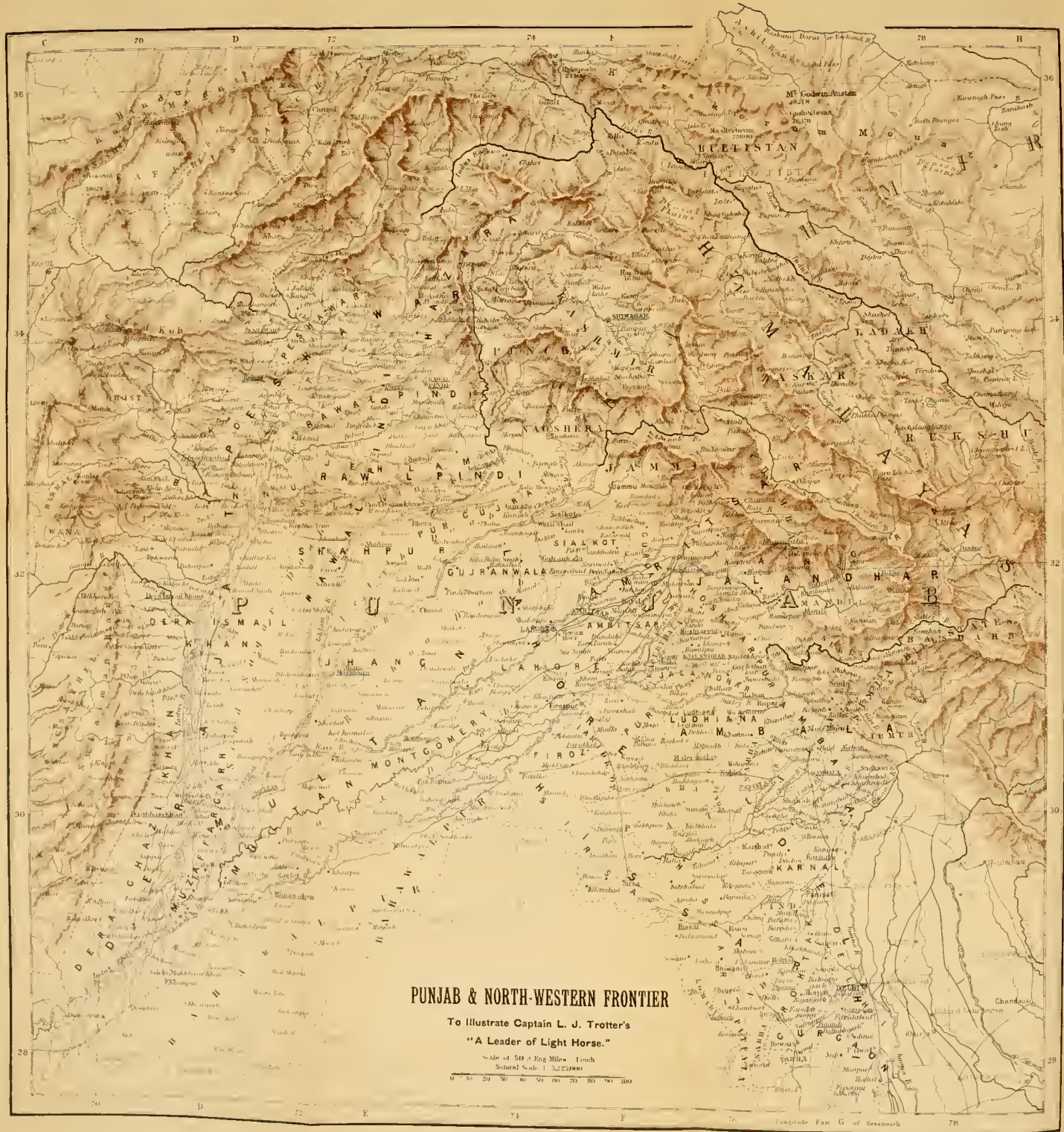


deacon Dealtry, John Peter Grant, Frederick Currie, and Sir Herbert Maddock were among the acquaintances whom he then made. Two happy days of September were spent by him at Garden Reach, in the house of his new friend Sir Lawrence Peel, then Chief Justice of Bengal. Hodson justly speaks of him as " a thoroughly nice agreeable man," and feels "quite a different animal after two days spent in comfort and comparative freedom from heat."

After three weeks spent in the city of palaces Hodson began his voyage by steamer up the country towards Agra, then the capital of the North-West Provinces. Here on October 18 he became the guest of the Lieutenant-Governor, James Thomason, an old family friend and connection, "who from that time to his death," says Mr George H. Hodson, "treated him with as much affection, and took as deep an interest in his career, as if he had been his own son."

At this time Sir Henry Hardinge was GovernorGeneral of India, and Sir Hugh Gough, the conqueror of the Gwalior Marâthas, was his commander-in-chief. The clouds were even then lowering along the Satlaj, and troops were preparing to march from various stations towards the point of possible danger. Before leaving Calcutta Ensign Hodson had been appointed to do duty with the 2nd Bengal Grenadiers, a native regiment which was presently to form part of the Governor-General's escort from Agra to Ferozepore. "Nothing," he writes, "was ever so kind as Mr Thomason has been. . . . He is certainly a most delightful man, and his affectionate manner to me is quite touching. He has just given me a 
horse for the march, and seems bent on making me comfortable." On November 2 he left Thomason's hospitable roof, to become ere long an actor in one of the bloodiest wars recorded in Indian history.

In spite of the delay caused by a sudden attack of fever and dysentery, he gained the headquarters' camp near Delhi on the morning of the $7 \mathrm{th}$. His first experiences of a cold-weather march with troops in Northern India are described so vividly in one of his own letters that no excuse is needed for reproducing the description here :-

"Soon after 4 A.M. a bugle sounds the réveillé, and the whole mass is astir at once. The smoke of the evening fires has by this time blown away, and everything stands out clear and defined in the bright moonlight. The sepoys, too, bring the straw from their tents, and make fires to warm their black faces on all sides; and the groups of swarthy redcoats stooping over the blaze, with a white background of canvas, and the dark clear sky behind all, produce a most picturesque effect as one turns out into the cold. Then the multitudes of camels, horses, and elephants, in all imaginable groups and positions, the groans and cries of the former as they stoop and kneel for their burdens, the neighing of hundreds of horses mingling with the shouts of the innumerable servants and their masters' calls, the bleating of sheep and goats, and, louder than all, the shrill screams of the Hindoo women, almost bewilder one's senses as one treads one's way through the canvas streets and squares to the place where the regiment assembles outside the camp.

"A second bugle sounds 'the assembly.' There is a blaze of torches from the Governor's tents; his 
palanquin carriage, drawn by four mules and escorted by jingling troopers, trots to the front. The artillery thunder forth the morning gun as a signal that the great man is gone, the guns rattle by, the cavalry push on after them, and then at length our band strikes up. 'Forward' is the word, and the red (and black) column moves along, by this time as completely obscured by the dense clouds of dust as though they were in London during a November fog. We are not expected to remain with our men, but mount at once and ride in a cluster before the band, or ride on a quarter of a mile or so in twos and threes, complaining of the laziness of the great man's people and of the dust and cold, as if we were the most ill-used of her Majesty's subjects. As soon as we're off the ground, and the road pretty clear, I dismount and walk the first eight miles or so, this being the time to recover one's powers of locomotion. The cold is really very great, especially in the hour before sunrise-generally about one and a half or two hours after we start. It soon gets warm enough to make one glad to ride again, and by the time the march is over, and the white city is in sight, the heat is very great, though now diminishing daily. It is a sudden change of temperature, truly, from near freezing at starting to $90^{\circ}$ or $100^{\circ}$ at arriving; and it is this, I think, which makes us feel the heat so much in this climate. In the daytime we get on very well, the heat seldom exceeding $86^{\circ}$, and often not more than $84^{\circ}$ and $82^{\circ}$ in tents. It sounds hot, but a house or tent at $84^{\circ}$ is tolerably endurable, especially if there is a breeze. My tent is twelve feet square inside, and contains a low pallet-bed, a table, chair, two camel- 
trunks, and brass basin for washing. I will get a sketch of the camp to send you.

"Nov. 18. - This nomad life is agreeable in many respects, and very healthy, and one sees a great deal of the country; but it destroys time rather, as the march is not over generally till half-past nine or ten, and then breakfast, a most eagerly desired composition, and dressing afterwards, do not leave much of the day before the cool evening comes for exercise, or sight-seeing and dining, and by nine most of us are in bed or near it."

By December 2 the Governor-General had pitched his camp near Umbâla, where a large portion of Gough's army was already mustering for its march towards the frontier: Hodson got leave to ride on and see the troops assemble to greet the GovernorGeneral. "I never saw," he wrote, "so splendid a sight: 12,000 of the finest troops were drawn up in one line, and as I rode slowly along the whole front, I had an excellent opportunity of examining the varied materials of an Indian army. First were the English Horse Artillery, then the dashing dragoons of the 3rd Queen's, most splendidly mounted and appointed; then came the stern determined-looking British footmen side by side with their tall and swarthy brethren from the Ganges and Jumna-the Hindoo, the Mussulman, and the white man, all obeying the same word and acknowledging the same common tie; next to these a large brigade of guns, with a mixture of all colours and creeds; then more regiments of foot, the whole closed up by the regiments of native cavalry; the quiet-looking and Englishdressed Hindoo troopers strangely contrasted with 
the wild irregulars in all the fanciful un-uniformity of their native costume: yet these last are the men $I$ fancy for service. Altogether, it was a most interesting sight, either to the historian or soldier, especially as one remembered that these were no men of parade, but assembled here to be poured across the Satlaj at a word."

After the death of Ranjit Singh, the Lion of the Punjab, in 1839, the kingdom he had founded by force or fraud between the Sulaiman Hills and the Satlaj speedily became a prey to all the evils that spring from incapable rulers and a disciplined soldiery conscious of its own strength, and bound together by the heritage of a common creed. The Sikh army of the Khalsa, or "Chosen," combined the religious fervour of Cromwell's Ironsides with the military pride and restlessness of Roman prætorians or Turkish janissaries. This army had become a terror to their nominal masters at Lahore, who made a show of governing the Punjâb on behalf of its child sovereign, Dhulip Singh.

Thousands of these soldiers were encamped round Lahore, clamouring for the pay which a needy and thriftless Government was quite unable to grant them. If the whole Sikh army would only march across the Satlaj, they might count on getting all they wanted from the plundered cities of Hindustan.

Such was the bait held out to these sturdy rioters by some of the leading spirits in the Lahore Darbâr, or Council of State, who hoped thus to rid themselves of a formidable nuisance, and at the same time to maintain a secret understanding with the Government of India. In due 
time the bait took. On December 11 a great Sikh army, well equipped with guns, began crossing the Satlaj not far from Ferozepore.

On December 15 the 2nd Grenadiers joined the main army which Gough was leading from Umbâla, by forced marches towards the Satlaj. "On the 17th," writes Hodson to his father, "we had a march of thirty miles, in the daytime too, with scanty food. On the 18th, after a fasting march of twenty-five miles, we were summoned, at halfpast four in the afternoon, to battle, which lasted till long after dark." This was the battle of Mudki, the first of those fights which taught us to respect the prowess of our Sikh foes, and to admire the stubborn courage with which they fought their guns. Hodson's regiment formed part of Gilbert's division. "Almost the first shot which greeted our regiment" (continues Hodson), "lkilled the man standing by my side, and instantly afterwards I was staggered by a ball from a frightened sepoy behind me grazing my cheek and blackening my face with the powder, so close was it to my head! We were within twenty, and at times ten, yards of three guns blazing grape into us; and, worse than all, the bushes with which the whole ground was covered were filled with marksmen, who, unseen by us, could pick us off at pleasure. No efforts could bring the sepoys forward, or half the loss might have been spared had they rushed on with the bayonet. We had three officers wounded out of our small party, and lost many of the men. We were birouacked on the cold ground that night, and remained under arms the whole of the following day." 
Three days later began at Firozshah the long, fierce, and changeful struggle on which for nearly two days the fate of India may be said to have hung. Around the village of Firozshah the Sikhs had for some days been intrenching themselves in a kind of oblong square a mile long by half a mile deep. More than a hundred guns, light and heary, defended a position held by about 35,000 men, of whom 10,000 were horse. Gough's army, strengthened betimes by General Littler's contingent from Ferozepore, numbered about 17,500 men supported by sixty-nine light field-guns. It was against the longest face of the Sikh camp that our troops were led on the afternoon of December 21 over flat and open ground dotted here and there by patches of low jungle.

"On the evening of the 21st, as we rushed towards the guns," writes Hodson to his father, "in the most dense dust and smoke, and under an unprecedented fire of grape, our sepoys again gave way and broke. It was a fearful crisis, but the bravery of the English regiments saved us. The colonel (Hamilton), the greater part of my brother officers, and myself were left with the colours and about thirty men immediately in front of the batteries! Our escape is most providential, and is, I trust, thankfully acknowledged by us. A ball-from a shell, I fancy - struck my leg below the knee, but happily spared the bone, and only inflicted a flesh wound. I was also knocked down twice-once by a shell bursting so close to me as to kill the men behind me, and once by the explosion of a magazine or mine. I am most thankful, indeed, for my escape from death or maiming." 
How the night of the 21st was spent by our tired and famishing soldiers Hodson himself shall tell us. His own regiment was bivouacking beside the Queen's 80th Foot, an old Staffordshire regiment, whose ranks still contain many men from that county. "It is a splendid corps," says Hodson, "well-behaved in cantonments, and first-rate in action. I lay between them and the 1st European Bengal Fusiliers [his future regiment] on the night of the 21st of December, when Lord Hardinge called out, " 80 th! that gun must be silenced.'" It was a heavy Sikh gun, which was playing havoc with the troops of Gilbert's division, and the 1st Europeans were ordered to support their comrades of the 80th. "They jumped up, formed into line, and advanced through the black darkness silently and firmly: gradually we lost the sound of their tread, and anxiously listened for the slightest intimation of their progress. All was still for five minutes, while they gradually gained the front of the battery whose fire had caused us so much loss. Suddenly we heard a dropping fire, a blaze of the Sikh cannon followed, then a thrilling cheer from the 80th, accompanied by a rattling and murderous volley, as they sprang upon the battery and spiked the monster gun. In a few more minutes they moved back quietly, and lay down as before in the cold sand; but they had left forty-five of their number, and two captains, to mark the scene of their exploit by their graves."

Soon after daybreak of the 22nd Gough and Hardinge-for the latter had waived his right as Governor-General to the chief command, and contented himself with leading the left wing of the 
army of the Satlaj-formed up their shattered troops for the work that still lay before them. In the teeth of a brisk cannonade they drove the enemy out of the village of Firozshah, and before noon were masters of the whole intrenched camp. But their trials were not yet over, for presently Tej Singh was seen in the distance leading an army, reckoned at 20,000 men and sixty guns. Our fainting troops nerved themselves for one supreme effort, and the cavalry were sent forward from both flanks. Our guns were useless for want of ammunition. But the Sikh leader, for reasons best known to himself, declined the challenge, and speedily withdrew towards the Satlaj. The victory was ours at last, but dearly purchased with the loss of more than 2400 men, of whom nearly 700 died on the field.

On the night of the 24th our weary troops marched on to Sultanpur, about five miles from the scene of that terrible carnage. Here, says Hodson, "we got some food, and into our beds, after four days and nights on the ground, alternately tried with heat and cold, now most severe at night, and nothing but an occasional mouthful of black native bread. I think, during the four days, all I had to eat would not compose half a home breakfast-loaf, and for a day and night we had not even water: when we did get water, after driving the enemy from their camp, it was found to have been spoilt with gunpowder! It was like eating Leamington water, but our thirst was too great to stick at trifles." 1

I In one of his letters to Mr Thomason he says : "I have unfortunately been ill ever since we moved from the scene of the action of 
From the same place he writes on December 26: "We are resting here comfortably again in our tents, and had a turkey for our Christmas dinner last night. The rest is most grateful. We had only nine hours in bed out of five nights, and then the next four were on the ground. So you see I have come in for the realities of a soldier's life pretty early in my career; and since I am spared, it is doubtless a great thing for me in every way. There never has been anything like it in India, and it is not often that an action anywhere has lasted thirty-six hours as ours did. It is called a succession of three engagements, but the firing never ceased for a quarter of an hour. Infantry attacking guns was the order of the day, and the loss occasioned by such a desperate resort was fearful.

"How different," he continues, "your Christmas week will have been from mine! This time last year I was quietly staying at Bisham, and now sleeping on the banks of the Satlaj, with a sea of tents around me for miles and miles! The last few days seem a year, and I can scarcely believe that I have only been four months in India, and only two with my regiment."

About this time Hodson's anxiety with regard to his mother was greatly relieved by the accounts that reached him of her improving health. "The

the 21st and 22nd of December. All of us have been complaining more or less, in consequence, it is supposed, of the horrible water we found at Firozshah. If not actually poisoned it was at least saturated with gunpowder, and there were animals found in the wells. ... I have been, however, confined to my tent and bed for eight or nine days with violent dysentery and general cold, whicl has settled down into an obstinate cough. I am terribly pulled down at present, but I trust before we again commence work I may be fit to take my place." 
two last mails have brought me letters from herself, which is the best possible sign of increasing strength." But the seeming improvement was only a passing rally. About half a year later, while Hodson was staying with his new friend and future benefactor, Colonel Henry Lawrence, his heart was saddened by news of his mother's death. It was a terrible blow to the son, who, in his own words, "had up till the last moment never allowed himself to doubt that he should see her again." No one, he wrote to his sister, "can understand the intenseness of hope until they have been separated, as I have, from every one dear to them. . . Even my father's last letters, which I now wonder did not alarm me at the time, had failed to convey conviction to my mind." The blow seemed all the harder to bear, as it fell upon him while he was staying at Simla "in a house full of people," from whom he had to conceal his grief.

During the first weeks of 1846, while Gough was awaiting fresh reinforcements with the heavy guns from Delhi, the Sikhs lay idle on their own side of the Satlaj. At length, towards the end of January, a strong Sikh force, under Ranjor Singh, recrossed the river and threatened Ludiâna. On January 28 the victory of Aliwâl, skilfully won by Sir Harry Smith, sent the enemy flying back across the Satlaj with the loss of fifty-six guns, and relieved our frontier posts from all present danger. Meanwhile a great Sikh army was busily intrenching itself on both sides of the Satlaj about Sobraon and Harîki, and in the very face of the line held by Gough. 
When the 2nd Grenadiers were ordered off to a post some miles in the rear of Gough's army, its place in the front was taken by another sepoy regiment, the 16th Grenadiers, who had formed part of Nott's "spiendid infantry" at Kandahar during the first Afghan war. Into this regiment Ensign Hodson was allowed to exchange, "not liking the notion of returning to the rear while an enemy was in front." He joined his new regiment on the evening of February 9 . He was just in time to share in the hard fighting and the decisive victory of Sobraon, which on February 10 closed the first Sikh war. "About three in the morning," writes Hodson to his father, "we advanced towards the Sikh intrenchments along the river's bank. Our guns and ammunition had all come up a day or two before, and during the night were placed in position to shell their camp. At daybreak seventeen heavy mortars and howitzers, rockets, and heavy guns commenced a magnificent fire on their position."

For the first time in his Indian warfare the fiery old commander-in-chief had allowed his splendid artillery to try their worst upon the foe. At half-past eight he let his infantry go. "Sir R. Dick's division on the right, and ours (Gilbert's) in front, covered by our fire from the batteries. On we went as usual in the teeth of a dreadful fire of guns and musketry, and after a desperate struggle we got within their triple and quadruple intrenchments, and then their day of reckoning came indeed. Driven from trench to trench, and surrounded on all sides, they retired, fighting most bravely, to the river, into which they were driven 
pell-mell, a tremendous fire of musketry pouring on them from our bank, and the Horse Artillery finishing their destruction with grape. "The river is literally choked with corpses, and their camp full of dead and dying."

Hodson himself "had the pleasure of spiking two guns which were turned on us. Once more I have escaped, I am thankful to say, unhurt, except that a bullet took a fancy to my little finger and cut the skin off the top of it-a mere pinscratch, though it spoilt a buckskin glove. I am perfectly well: we cross in a day or two, but I fancy have done with fighting."

The fighting was over for that present. The Sikh army was utterly broken: all their guns, sixty-seven in number, a great many standards, and a camp full of warlike stores, had fallen into our hands. A few days later the fortress of Philôr, on the right bank of the Satlaj, opposite Ludiâna, surrendered without a shot to the troops of Brigadier Wheeler. On February 13 Gough himself was writing his despatches from Kassûr, and two days later, at the same place, the Sikh leaders were listening to the terms on which alone they might secure the maintenance of the Sikh rule at Lahore. On February 27 Hodson writes to his sister from Lahore: "On the 17th we crossed the Satlaj, and are now encamped close to old Ranjit Singh's capital, without a shot having been fired on this side the river! The war is over; sixty days have seen the overthrow of the Sikh army, which, when that period commenced, marched from the spot on which the 
victors are now encamped, with no ferwer than 100,000 fighting men, now

' A broken and a routed host,

Their standards gone, their leaders lost.'

So ends the tale of the mightiest army, and the best organised, which India has seen. ... A campaign is a wonderful dispeller of false notions and young imaginations, and seems too stern a hint to be soon forgotten." 1

I The Sikh loss at Sobraon was reckoned at not less than 8000 killed and wounded, while Gough's army, about 17,000 strong, lost 320 officer's and men killed and 2063 wounded. Gilbert's division suffered heavily, losing 6 officers, 5 sergeants, and 109 men slain; 50 officers, 46 sergeants, 2 trumpeters, 685 privates wounded. 


\section{CHAPTER IV.}

FROM SABÂTHU TO KASHMIR. 1846.

A MILLion and a half sterling was the fine which Sir Henry, now soon to become Lord Hardinge, inflicted on the Sikh Government for waging an unprovoked war with its peaceful neighbour. But the Lahore Treasury could not scrape together more than half a million. Gulâb Singh, Rajah of Jammu and a leading member of the Lahore Darbâr, offered to pay over the remaining million if Lord Hardinge would recognise him as sovereign ruler of Kashmir. His offer was accepted as the easiest way of replenishing the East India Company's exchequer, and of solving a rather knotty political problem. Out of the rest of Ranjit Singh's kingdom the GovernorGeneral reserved for his master's own keeping the Jalandhar Doab, the strip of country lying between the Satlaj and the Biyas.

The intriguing mother of little Dhulip Singh retained her place at the head of the Lahore Darbâr with Lâl Singh for her Wazir. The old Khalsa army was to be cut down to a third of its former strength, and a strong British garrison under General Littler ensured for a time the 
peace of the Sikh capital. Colonel Henry Lawrence, who had been summoned from Nipâl on the death of the gallant Major Broadfoot, was selected for the post of British Resident and general adviser at the Lahore Court. Such were the measures by which Lord Hardinge hoped to stave off for many years 'the final day of reckoning between the Indian Government and the recognised rulers of the Punjâb.

When the Governor-General put his seal to the treaty of March 9 the hot weather was fast setting in, and most of the troops composing the army of the Satlaj were already hurrying back to their respective cantonments. Hodson himself had once more exchanged into the 26th Sepoys, with whom he marched towards Umbâla. By March 26 the last of the homeward - bound regiments had recrossed the Satlaj by the noble bridge of boats which our engineers had got ready. The sight of the regiments, mostly European, filing across the bridge, struck Hodson with keen admiration of the dusty, travel-stained, war-worn remnants of the troops who had fought so doggedly at Firozshah and Sobraon. "With that cool firm air of determination which is the most marked characteristic of English soldiers, regiment after regiment passed on, cavalry, artillery, and infantry in succession, their bands playing quick steps and national tunes as each stepped upon the bridge. . . As each regiment moved up on this side the river, our fine old chief addressed a few words of congratulation and praise to each; they pushed on to their tents, and a genuine English cheer, caught up and repeated from corps to corps 
and a thundering salute from the artillery, proclaimed the final dispersion, and bade an appropriate farewell to the army of the Satlaj."

Writing to his dear friend, Mr F. A. Foster, on March 30, Hodson describes his own experiences of the long, hot, dusty march towards Umbâla : "Be it known to all stayers at home that writing a letter is a very serious business, indeed, to dwellers in tents; for besides the usual interruptions caused by duty and marching, and the more public sort of existence one leads in camp, one is exposed to every vicissitude of heat and cold and wind, as if one were sitting under an umbrella almost. I don't speak of the magnificent houses of commanders-in-chief and governor-generals, but of such small tents as befit subalterns, captains, and Sir Charles Napier! He is content with the same accommodation as I am, but then he really is a great man as well as a great soldier, not a little one made big by fortune. . . . But the dust! No one who has not been in the sandy plains of Upper India can conceive what a windy day brings with it. I am wrong in calling it sand; it is fine alluvial soil pulverised by the heat so finely that it is impalpable to the touch, lying ankle-deep for miles and miles of country. You may guess how this rises with the tramp of so many thousands of men and horses, and fills the air so densely that one can hardly breathe, and one's eyes become blinded with accumulated filth, and the eyelashes thickened and clotted with our mother earth. On a windy day this rushes into one's tent and covers everything with a blanket of earth as effectually as snow does the 
country at home. When the said wind becomes a hot one, as it is rapidly doing by this time of year, the nuisance is terribly aggravated, and tents become almost unbearable-I might say quite, but that they must be borne. However, we have had great luck in the weather ever since I became a nomad and a denizen of tents; and it has so many attractions that I like it very well, especially when anything is going on: now, however, when merely marching home, and at this season of the year, it is getting disagreeable. We march at 3 in the morning to get to our new ground before the heat of the day begins; but I imagine the thermometer is about $98^{\circ}$ or from that to $105^{\circ}$ in tents even now, and it is cool for the time of year!"

In the same letter Hodson treats his friend to some outspoken criticisms on the course of the late campaign :-

"England, I see, is ringing with the deeds of the 'army of the Satlaj.' How would it not be roused from one end to the other were the whole truth known! Were the tissue of mismanagement, blunders, errors, ignorance, and arrogance displayed during the short but 'glorious' campaign exposed, the indignation excited by it would, I trust, be the beginning of a new era for India. The despatches are most disgraceful. The most unblushing falsehoods are put forth, both as to facts, figures, and individuals, with a coolness worthy of Napoleon. I have little hopes, however, of any improvement. Success - ultimate success - throws its cloak of charity over unnumbered errors, and in a few months it will be 
forgotten that 100 English gentlemen, some thousands of brave soldiers, have died to retrieve their generals' errors. The one great fact should be known from end to end of the land, that on the 21st of December 1845 an Anglo-Indian army was repulsed, if not beaten, by an inferior force in point of numbers and skill, and undoubtedly inferior to English soldiers in courage, though immensely superior in artillery, and in knowledge of the ground, and in generalship!! Will it be believed that a large proportion, if not the greater part, of our loss was eaused by our own regiments being so badly handled that they fired upon one another incessantly! My own regiment reeeived a volley from behind as we advanced; the 1st Europeans fell before our eyes in numbers by a volley from our own 45th Sepoys!! Is not all this disgraceful and eruel to an umparalleled degree!

"It was near being a sad day for the Indian empire: nothing but the cool determination of the soldiers not to be beaten saved the day, and enabled them to resist, unsupported by artillery, the two vigorous attacks made upon us on the 22nd, after we had driven them from their position at daybreak, by Tej Singh's fresh troops and admirably served artillery. I grant that the battle of Sobraon on the 10th of February was a splendid affair, and well managed on the whole, though here again our magnificent guns and mortars were comparatively useless from want of ammunition! The despatehes are pretty truthful on this last affair, except in minor points. My division, General Gilbert's, had the pleasure and honour of attacking the whole front of the formidable intrenchment 
lined by thirty - three regular regiments, and a desperate struggle we had for it, and the loss in that part of the affair was awful. But I must draw up short, and try hereafter to give you some idea of 'my first campaign.' I have been most mercifully preserved through the whole of it. As you may have seen in the papers, I was wounded at Firozshah by a shot in the leg, but it was of but little consequence. In each of the other actions I was touched, and yet I am alive and well, and in better health and spirits than I have been for months, and I trust in some things a better man. It is an excellent thing for one, you may depend upon it, to be exposed to the fire of an enemy, and a field of battle is a stern but truthful and valuable monitor: may its lessons not be forgotten!"

By the 13th of April the 26th Native Infantry had reached Umbâla, on their way to Bareilly in Rohilkhand. By this time Hodson had fondly hoped to see himself transferred to the 1st European regiment, who had just been styled Fusiliers for their distinguished services in the late campaign. "It is the finest regiment in India," he writes, "with white faces, too, and a very nice set of officers. I have been brigaded with them all along."

He had evidently had enough of soldiering with men who could not be trusted to follow their white officers in the hour of need. But the answer to his latest application was so long in coming that the 26th Sepoys were quietly cantoned among the groves of Bareilly before he found himself posted to the regiment of his choice. 
How poor an estimate William Hodson had in these few months learned to form of the regular native army of Bengal may be seen from the letter he wrote about this time to his kind friend, James Thomason, at Agra: "In discipline and subordination they seem to be lamentably deficient, especially towards the native commissioned and non-commissioned officers. On the march I have found these last give me more trouble than the men even. My brother officers say that I see an unfavourable specimen in the $2 \mathrm{nd}$, as regards discipline, owing to their frequent service of late and the number of recruits; but I fear the evil is very widespread. It may, no doubt, be traced mainly to the want of European officers. This, however, is an evil not likely to be removed on any large scale. Meantime, unless some vigorous and radical improvements take place, I think our position will be very uncertain, and even alarming, in the event of extended hostilities. You must really forgive my speaking so plainly, and writing my own opinions so freely. You encouraged me to do so when I was at Agra, if you remember, and I value the privilege too highly as connected with the greater one of receiving advice and counsel from you, not to exercise it, even at the risk of your thinking me presumptuous and hasty in my opinions." 1

It was about this time that Thomason himself, writing to Hodson's father, expressed his pleasure at William's evident success in winning the esteem and goodwill of his brother officers. "I had some little fear," he adds, "that his great superiority

$$
1 \text { 'Fraser's Magazine' for February } 1859 .
$$


in age and attainments to those of his own standing in the army might make him the object of envy and disparagement. I felt that he had no easy task before him, and that it would be difficult to conduct himself with discretion and becoming humility in such a position. He was quite aware, of the difficulty when we talked the matter over at Agra, and I am much pleased to see the success which has attended his prudent exertions."

In May of this year, 1846, while the hot winds were blowing their fiercest over the scorched plains below, the 1st Bengal Fusiliers were resting from war's hardships in the cool hill-station of Sabâthu, lying nearly half-way on the old road from Kalka up to the lofty wood-crowned heights of Simla. Hodson resolved to reach Sabâthu by making his way across the long range of mountains that stretch north-westwards from Naini-Tal. A friendly civilian offered to take him from Bareilly up to Naini-Tal, whence he continued his journey on foot, trusting " that my old powers of walking and endurance will revive in the mountain air."

But the rainy season, which that year set in early in June, compelled Hodson to change his plans by the time he reached Mussooric. After a halt of two days at that station, he rode down to Dera Dun, and travelled thence by post through Saharanpur and Umbâla to the foot of the Simla hills. At Kalka he mounted his own horse and rode on straight to Sabâthu. "Here I am at last," he writes on June 16, "with my own regiment, and with the prospect of being quiet for four months. I am eighth second lieutenant; a distinguished position, is it not? at the age of five-and-twenty. 
The campaign, I am sorry to say, did me no good in the way of promotion, owing to my not having been 'posted' permanently before it commenced."

On July 3 Hodson begs his father to congratulate him on being posted to so splendid a corps as the 1st Fusiliers, "now, alas! a mere shadow of what it was six months ago. We could only muster 256 men under arms when we were inspected by Sir Walter Gilbert on the 1st; but then there was a most picturesque body of convalescents present with their empty sleeves, pale faces, and crutches, but looking proudly conscious of their good conduct, and ready 'to do it again.' We are under much stricter discipline in this corps, both officers and men, and obliged to be orderly and submissive. No bad thing for us either. I hold there is more real liberty in being under a decent restraint than in absolute freedom from any check. I have been much more reconciled to India since I joined this regiment. It is pleasant to have white faces about one, and hear one's own tongue spoken; and then, besides, there is a homeloving feeling in this corps which I have never met with in India." 1

On August 31 Hodson went up to Simla to spend a week with his new friend, Colonel Henry Lawrence, to whom Thomason had introduced him by letter in the previous March. This was to prove the beginning of a friendship which lasted throughout both their lives. The week grew into a month, "thanks to Colonel Lawrence's pressing, and Colonel Orchard's, my colonel's, kindness."

At Lawrence's own desire the two lived, worked,

${ }^{1}$ Hodson of Hodson's Horse. 
and slept together in the same rooms, Hodson making himself generally useful by writing out abstracts of his friend's letters and copying his confidential papers. "He is amazingly kind," wrote Hodson, "and tells me all that is going on, initiating me into the mysteries of 'political' business, and thus giving me more knowledge of things and persons Indian than I should learn in a year of ordinary life-ay, or in three years either. This is a great advantage to my ultimate prospects. . . . He makes me work at Hindustani, and has given me a lesson or two in the use of the theodolite and other surveying instruments, to the end that I may get employed in the Surveying Department, after two years of which, he says, 'I shall be fit for a Political."

The kindly old captain of artillery, who had in his time played many parts in his country's service, was delighted with the many proofs of his young friend's zeal and capacity. Writing home in September to his wife, Henry Lawrence says: "I brought up with me from Sabâthu a fine young fellow, by name Hodson, son of the Archdeacon of Stafford. $\mathrm{He}$ is now (10 P.M.) sleeping in my little office-room, where I am writing. Thomason recommended him to me, and I have seldom met so promising a young fellow. He left the native branch of the army at the expense of some steps, because he did not like the conduct of the sepoys. He was for four years with $\mathrm{Dr}$ Arnold, and two in the Sixth Form under his eye. He speaks most affectionately of him. I will try to get leave for him for a month, to accompany me to Lahore and Jammu in October. ... I get a good deal of help from Hodson, who 
works willingly and sensibly. Perhaps you may meet the family at Lichfield."

"If I were only nearer you all," writes Hodson, "and had any old friends about me, I should have nothing to regret or wish for. It is there that the shoe pinches. All minor annoyances are easily got rid of, but one does find a wonderful lack of one's old friends and old associations. Society is very different here from ours at home, and different as it is, I have seen very little of it. Nor an I, with my previous habits, age, and education, the person to feel this an indifferent matter; but, on the contrary, all the drawbacks of Indian existence come with redoubled force from the greatness of the contrast. Still I do not let these things annoy me or weigh down my spirits, but strive, by keeping up English habits, tastes, and feelings, and looking forward to a run home (thus having a motive always in view), to make the best of everything as it occur's, and to act upon the principle that mere outward circumstances don't make a man's happiness."

It is not surprising to find that a young man of Hodson's years, tastes, and training did not take kindly to Anglo-Indian ways and traditions, or that he should feel contempt for a regular Indian, "a man who thinks it fine to adopt a totally different set of habits and morals and fashions, until, in forgetting that he is an Englishman, he usually forgets also that he is a Christian and a gentleman." A Cambridge graduate of twenty-five would naturally have little in common with boys of sixteen and seventeen fresh from school, free from all home restraints, and launched without warning into a strange new world of moral and social complexities. 
Their ways were not his ways, nor would he deign to lay aside one of his English habits for the sake of winning the goodwill of younger or less fastidious comrades.

Things at this time were not going smoothly beyond the frontier. Gulâb Singh's entrance into Kashmir had been followed by his speedy retirement before a body of the insurgents, who drove his troops out of the valley in the name of their late governor, Shaikh Imâm-ud-din. Hodson expects that "October will see an army assembled to frighten them into submission. ... We seem bound to see him established on the throne we carved out for him, and it is our only chance of keeping peace and order; though at the best he is such a villain, and so detested, that I imagine it will be but a sorry state of quietness-

'The torrent's smoothness ere it dash below." "

On October 1, 1846, Hodson left Sabâthu to join Colonel Lawrence at the foot of the hills. At Rupar on the Satlaj they took boat for Ferozepore, "and came across to Lahore during the night in a capital barouche belonging to the Rani, with relays of horses and an escort of cavalry." While two British columns advanced northwards from Lahore and Jalandhar, Lawrence himself marehed towards Kashmir at the head of some 10,000 of those very Sikhs who had fought against us at Firozshah and Sobraon. Hodson was delighted at the thought of seeing Kashmir, and was " gaining great advantage from being with these 'politicals,' in the way of learning the languages and the method of governing the natives. I have been hard at work day and 
night for some time now writing for Colonel Lawrence."

In the last week of October Lawrence was encamped at Thána, at the foot of a pass leading into the peerless valley of Kashmir. Hodson himself was one of the very few English officers who had accompanied him on that memorable march. On the plain below were lying in picturesque confusion and motley garb the combined forces of Jammu and Lahore. "The spare stalwart Sikh, with his grizzled beard and blue turban of the scantiest dimensions, side by side with the huge-limbed Afghan, with voluminous head-gear and many-coloured garments. The proud Brahmin in the same ranks with the fierce 'Children of the Faithful'; the little active hillman; the diminutive, sturdy, platter-faced Gurkha, and the slight-made Hindustani, collected in the same tents, and all alike clothed in a caricature of the British uniform."

Hodson had seen "a great deal of the native sirdars, or chiefs, especially Tej Singh, who commanded the Sikh forces in the war, and of the Maharajah,-the former a small, spare, little man, marked with the smallpox, and with a thin scanty beard, but sharp and intelligent, and by his own account a hero." The Maharajah, Gulâb Singh, was " a fine, tall, portly man, with a splendid expressive face, and most gentlemanly pleasing manner, and fine-toned voice-altogether the most pleasing Asiatic I have seen, to all appearance the gentlest of the gentle, and the most sincere and truthful character in the world. And in his habits he is certainly exemplary; but he is the cleverest hypocrite in the world; as sharp and acute as possible, 
devoured by avarice and ambition, and when roused, horribly cruel. This latter accusation he rebuts by alleging the necessity of the case and the ferocity of those he has to deal with. To us, however, his fondness for flaying men alive, cutting off their noses and ears and hands, \&c., savours of the inexcusable. He was accused of having flayed 12,000 men, which he indignantly asserted was a monstrous calumny, as he only skinned three; afterwards he confessed to three hundred! Yet he is not a bit worse, and in many ways infinitely better, than most native princes. Lawrence doubts whether one could be found with fewer faults, if placed in similar circumstances."

Of the costumes of the Sikh sirdars, "the effect," says Hodson, "is always good, however bright they may be. They never make a mistake in colours." On the 25th Lawrence knew there would be no fighting, for the recusant Imâm-ud-din was already on his way to make full submission. By the end of October he had yielded himself up to the safe keeping of Captain Herbert Edwardes, who on the 1st of November brought him into the camp of Colonel Lawrence.

While Edwards was escorting his penitent captive to Lahore, Hodson himself accompanied his patron into the beautiful valley for the purpose of installing Gulâb Singh in the capital of his new dominions. On November 4 Lawrence's party crossed the Pir Panjal Pass 12,000 feet above the sea, with snow all around them. The road from Thána to the top of the pass was, in Hodson's words, "most lovely the whole way, winding up a glen wooded magnificently, and the rocks towering above us on all sides; the trees 
were all in their varied autumn dress, surmounted by forests of pine: altogether I never saw so grand a scene." On the 5th the three Englishmen, Lawrence, Browne, and Hodson, rode down into the valley "amid the acclamations of an admiring population of beggars!" A few days spent in the valley sufficed to carry out Lawrence's plans for the pacification of Kashmir.

This chapter may fitly close with Hodson's description of the men and women of Kashmir: "They are a poor wretched set, only good for beasts of burden,- -and certainly they can carry a vast load, -their dress, both men and women, being a loose wide-sleered smock-frock of dirty sackcloth-looking woollen. The men wear a dirty skull-cap on their shaven 'nobs,' and the women a crimson machine, like a flower-pot saucer inverted, from which depends a veil or cloth of the same texture as the frock; legs and feet clothed in their native dirt. The women are atrociously ugly, and screech like the witches in 'Macbeth' - so much so, that when the Agent asked me to give them a rupee or two, I felt it my duty to refuse firmly, but respectfully, on the ground that it would be encouraging ugliness!" 


\section{CHAPTER V.}

"FRESH WOODS AND PASTURES NEW." 1846-1848.

BeFore returning to Sabâthu Hodson had to play his part in a certain drama enacted at Lahore by special command of Lord Hardinge. As soon as Lawrence reached Lahore a commission of five British officers, headed by $\mathrm{Mr}$ (afterwards Sir Frederick) Currie, sat in judgment upon Lâl Singh, the treacherous Wazír who had secretly prompted the rebellion of Shaikh Imâm-ud-din. The Wazír's guilt was proved beyond question, and the queenregent's worthless paramour was deposed from his high office and sent off as a state prisoner to the fort of Agra.

Writing to Mr Foster from Sabâthu on the last day of 1846, Hodson speaks of his own modest share in the historic tragi-comedy, which led up to the treaty of Bhairowal,- a treaty under which Henry Lawrence, as president of a remodelled council of regency, became virtual ruler of the Punjâb: "You will see in the papers an account of the new arrangement for the occupation of the Punjâb; but you will not see an account of the share your unfortunate friend had in it, and the rather conspicuous part I played at Lahore during the late 
investigation, which ended in the deposition of the Wazír, Lâl Singh. I was sent both days to bring him and his Court to the tents where the proceedings were being carried on; and when he was deposed, I was commissioned to accompany him to his honourable confinement. I an not a very nervous subject in these matters, but it might have been anything but a joke taking a fallen Sikh ruler to his place of durance unaccompanied by a single man save his own wild fanatic followers. Yet I and two other English officers were allowed to take him away, put him down at his sponginghouse, and ride away without so much as a stone being thrown! and less than a year ago this very man was one of the leaders of the most formidable armies that ever threatened our power in India."

"I have still," he writes, "two second lieutenants above me. However, it would be worth while to exchange at a loss into this corps. I am uncommonly proud of it, or at least of what remains of it, for we are hardly more than a skeleton. Lord Gough, in reviewing us the other day, said he would rather have the 300 men we had left, to go into action with, than any other regiment a thousand strong! This, even when taken cum grano, is very gratifying, and is, moreover, an expression of the opinion of the whole service. . . You know what good spirits I have always had, and that I was not apt to be gloomy, and yet even I find it hard not to be depressed very often. The want of society is very trying to a man who has left England at an age to appreciate its benefits; and our only society here is in our regiment, and though we are very fortunate in our present set, 
you can understand that there is not much to encourage one in the somewhat noisy companionship of a number of fellows nearly all one's juniors by some years. Ladies' society there is none: there are a few who call themselves such, but with very little reason, save that they are not men.

"There is much in India to interest one, mucb worthy of all one's efforts, many most important duties and influences, but nothing to call forth one's affections or any of the softer and more delightful feelings of youth and life. In fact, one's life is a harsh reality; nothing is left to the imagination; no amenities; no poetry; no music; nothing elegant; nothing refined. There is nothing left but to be up and doing, to be active and energetic while you can, and look forward to a happier state either here or hereafter. I certainly have commenced my Indian career under more favourable circumstances than often falls to the lot of a man on his first introduction: both in my own line and in the opportunities I have had of becoming initiated into the 'native mind' and principles of action during my sojourn with Colonel Lawrence."

As early as August 1846 Hodson and two Engineer officers had set out with Lawrence in search of a fitting site for the asylum which Lawrence had long been eager to erect among the Himalayan pines and cedars for the benefit of the children of our European soldiers. "We nearly fixed," wrote Lawrence, "on a spur of the Kussowlie Hill, but eventually selected the hill of Sanâwar as combining most of the requisites for an asylum-viz., isolation, with ample space and plenty of water, at a good height, in a healthy locality not far from 
European troops. The selection was most fortunate, and I doubt not I owe it to my companions." 1

As secretary to the new asylum, which was soon to bear the name of its illustrious founder, William Hodson in the spring of 1847 entered into a strange new world of multifarious labours and responsibilities. "Since the 1st of April," he writes to Mr Foster in August, "I have been deeply engaged in building and superintending the starting of 'an asylum for European soldiers' children in the hills,' the idea of which was started by Colonel Lawrence, and most liberal funds into the bargain. Throughout the summer I have had the sole direction of some 600 workpeople, besides keeping accounts and answering inquiries and letters from all parts of the country, in my capacity of secretary."

No wonder that the constant exposure during a very hot June knocked him up, and brought on an attack of illness from which he suffered more or less during the next two months.

"You would have been amused," he continues, " to see me undertake what might truly be called a magnum opus with so little previous training. It is only a specimen of the way in which India brings a man out, and of how varied and unusual are the calls upon the faculties of mind and body in the course of one's career in the East.

"Building is a totally different affair here from similar employment at home. You begin literally from the mine, the quarry, and the forest. You have actually to teach your workmen as you go on, and in my case to learn yourself at the same time! and to be prepared to explain and point out every,

1 Merivale's Life of Sir H. Lawrence. 
even the most simple, operation of handicraft. I have gone to the forest and selected trees from the wood, and when cut down, shown the carpenters how to eut planks from them, and then to make them into doors and windows. At other times I have made moulds for bricks and pointed out their use; or marked out rocks in the quarry, to be subdued by the chisel and hammer. In addition to this is the duty of drawing plans and designing buildings, of procuring workmen and paying them, and training the whole to a nigger's greatest difficulty- industry.' Of course you must understand that this description, though faithful as to my experience in this frontier country where our rule has been so short, would be exaggerated if applied to the long-established provinces below. Here contact and example and teaching have done their work, and things go on in a more smooth civilised fashion. . . However, I am far from grudging the labour in so good a cause, which will rescue the soldier's child from an infancy of contamination and ignorance, and an early death or life of sickly misery. Nor in a selfish point of view is it to be regretted, since I have got a name for willingness to work which will stand me in stead hereafter."

Colonel Lawrence, for his part, "seems determined," says Hodson in one of his letters home, "I shall have nothing to stop me; for his invariable reply to every question is, 'act on your own judgment'; 'do what you think right'; 'I give you carte blanche to act in my name and draw on my funds,' and so forth." The asylum was opened in due course by Mrs George Lawrence, 
wife of Henry's elder brother, Captain George Lawrence, who had been one of the Kabul prisoners during the first Afghan war.

In a letter to his brother, Hodson refers to his work at Sanâwar: "One is obliged to take to anything that offers to avoid the taedium vitce which the want of employment engenders in this 'lovely country,'-in those, at least, who have not learnt to exist in the philosophical medium of brandy and cheroots. Did I tell you, by the bye, that I abjured tobacco when I left England, and that I have never been tempted by even a night al fresco to resume the delusive habit? Nor have I told you (because I despaired of your believing it) that I have declined from the paths of virtue in respect to beer also, this two years past, seldom or never even tasting that once idolised stimulant! It has not been caused alone by a love of eccentricity, but by the very sensitive state of my inner man, achieved in India, which obliges me to live by rule."

During this year Hodson had certainly, to use his own words, "had a benefit of work, both civil and literary, for the Institution; and since Colonel Lawrence put an advertisement in the papers desiring all anxious persons to apply to me, I have had enough on my hands. It is all very well, but interferes no little with my reading; and I am sure to get more kicks than thanks for my pains from an ungrateful and undiscerning public. However, as long as Colonel Lawrence leaves everything so completely in my hands, and trusts so implicitly to my skill and honesty, it would be a shame not to work' ' unlike a nigger.'

"It is intended that the children should remain 
in the Institution until they are eighteen years of age, if their fathers be alive, and until somehow or other provided for should they be orphans. The majority of the boys will, of course, become soldiers ; but my belief is, that having been brought up in the delightful climate of the Himalaya, they will, aften ten or fifteen years, settle down in the various stations and slightly elevated valleys in these hills as traders and cultivators, and form the nucleus of the first British colony in India. My object is to give them English habits from the first, which they have in most cases to learn, from being brought up by native nurses from infancy. Part of the scheme is to make the Institution support itself, and I am very shortly going to start a farmyard. I have already got a fine large garden in full swing; and here you may see French beans, cabbages, strawberry plants, and fine potatoes free from disease. I steadfastly refuse the slightest dash of colour in admitting children. People may call this illiberal if they please; the answer is obvious. Half-castes stand the climate of the plains too well to need a hill sanitarium, and by mixing them with English children you corrupt those whom you wish to benefit." 1

In October 1847 the 1st Fusiliers-now the 1st Munster Fusiliers-began their march from Sabâthu towards Cawnpore. Hodson naturally did not relish the prospect of returning to mere regimental duty in the plains, and the adjutancy which he had meanwhile been led to hope for did not fall vacant at the time expected. But his kind patron intervened betimes on his young friend's behalf. Not

\section{Hodson of Hodson's Horse.}


the least noteworthy of Henry Lawrence's achievements in the Punjâb was the formation of that splendid corps of Guides, which was afterwards to win renown in many a frontier campaign, to say nothing of its matchless services during the Sepoy Mutiny of 1857. Lawrence, in his steadfast zeal for Hodson's advantage, had strongly adrised him to accept the adjutancy of his regiment as a useful step towards further distinction. "I know of no man," he added, "of double or treble your standing who has so good a prospect before him. Favour and partiality do occasionally give a man a lift, but depend upon it that his is the best chance in the long-run who helps himself. So far you have done this manfully, and you have reason to be proud of being selected at one time for three different appointments by three different men. Don't, however, be too proud. Learn your duties thoroughly. Continue to study two or three hours a-day, not to pass in a hurry, but that you may do so two or three years hence with éclat.... In oriental phrase, pray consider that much is said in this hurried scrawl, and believe that I shall watch your career with warm interest."

The disappointment regarding the adjutancy was more than compensated by the good fortune to which Hodson himself thus refers: "You will, I am sure, rejoice with me at my unprecedented good fortune in being appointed to a responsible and honourable post, almost before, by the rules of the service, I am entitled to take charge of a company of sepoys. I shall even be better off than I thought; instead of merely 'doing duty' with the Guide Corps, I an to be the second in command." 
This corps, as first raised in December 1846, consisted of one troop of horse and two companies of foot, placed under the command of Lieutenant (afterwards Sir Harry) Lumsden. Of the men at first enlisted some were Hindustani soldiers then serving in the Sikh army, while a few Pathâns who had served with us in Afghanistan, and some Mazbi, or low-caste Sikhs, formed the remainder of the infant corps. "The grand object of the corps," in Hodson's words, "is to train a body of men in peace to be efficient in war: to be not only acquainted with localities, roads, rivers, hills, ferries, and passes, but have a good idea of the produce and supplies available in any part of the country; to give accurate information, not running open-mouthed to say that 10,000 horsemen and a thousand guns are coming (in true native style), but to stop to see whether it may not be really only a common cart and a few wild horsemen who are kicking up all the dust; to call twenty-five by its right name, and not say fifty for short, as most natives do. This, of course, wants a great deal of careful instruction and attention. Beyond this, the officers should give a tolerably correct sketch and report of any country through which they may pass, be au fait at routes and means of feeding troops, and above all-and here you come close upon practical duties-keep an eye on the doings 'of the neighbours' and the state of the country, so as to be able to give such information as may lead to any outbreak being nipped in the bud."

Not content with procuring Hodson's appointment to the Guides, Lawrence found some preliminary work for his zealous follower in the country 
between Lahore and the Satlaj. "You must congratulate me," Hodson writes in December 1847 from Kassûr, "on having been appointed to the staff of the Resident at Lahore, a piece of good fortune almost unprecedented in one so young in the service. I owe it to the continued and unwearying kindness of Colonel Lawrence, and to an impression on the part of the powers that be, that I was game to work: one which, I must confess, I have done somewhat to deserre during the past year. I am now, in addition to the duties of the Guide Corps, employed in surveying, and making roads and canals under the chief engineer, so as to open up and improve the country of the Sikhs; while at the same time I have to keep an eye on the doings of the native officials, and protect the oppressed from injustice and tyranny. I have only within the last two days hunted out as pretty a case of murder and robbery as ever graced Newgate, and sent the worthies to Lahore for trial, besides several cases of theft and false imprisonment. . . . Within the last thirty-two days I hare marked out and cleared twenty miles of road through a wide jungle; collected and set to work upwards of 1000 men, and trained them to all kinds of employments which they had never seen before. In short, you may judge I have not been idle when I tell you that upwards of 50,000 Rs. have passed through my hands in the last nine months for public works. Till the last month this has been gratis on my part, but my new appointment comfortably doubles my regimental pay, which in these hard times is not a bad thing."

On November 30 Henry Lawrence quitted Lahore 
on sick-leave for two years to England. A few days earlier Hodson had paid him a farewell visit, and received his last instructions. " $\mathrm{He}$ is a genuinely kind-hearted mortal, and has been a brother to me ever since I knew him. I hope to see him back in two years, invigorated and renewed, to carry out the good work which he has so nobly begun." But events were already working to cut short the hardlyearned holiday of his noble-hearted chief. Henry Lawrence sailed homewards in company with Lord Hardinge on the 18th January 1848. The close of that year was to find Sir Henry Lawrence, K.C.B., back again in the Punjâb with another Sikh war raging around him. 


\section{CHAPTER VI.}

THE OUTBREAK AT MULTÂN, AND AFTER. 1848.

Amovg those who rejoiced in Hodson's appointment to the Guides was Captain (afterwards Sir Herbert) Edwardes, himself a subaltern in the 1st Bengal Fusiliers, who had lately been transferred to Lawrence's political staff. Writing home to his mother in the autumn of 1847, Edwardes thus speaks of his brother officer: "Young Hodson has been appointed to do duty with our Punjâb Guide Corps, commanded by Lieutenant Lumsden. The duties of a commandant or adjutant of Guides are at once important and delightful. . . . In short, it is a roving commission, and to a man of spirit and ability one of the finest appointments imaginable. I think Hodson will do it justice. $\mathrm{He}$ is one of the finest young fellows I know, and a thorough soldier in his heart."

Some busy weeks, however, of 1848 were yet to elapse before Hodson actually joined the Guides. By the middle of January he was off again from Kassûr "like a steam-engine, calling at a series of stations, puffing and panting, hither and thither, never resting, ever starting; now in a cutting, now in a tunnel; first in a field, next on a hill. . . . At 
present I am moving rapidly along the banks of a small canal which traverses the Doâb, between the Ravi and Biyas rivers, for purposes of irrigation; accompanying Major Napier [afterwards Lord Napier of Magdala], to whom the prosecution of all public improvements throughout the Land of the Five Rivers belongs."

On the 15th he is resting for the day at Dinanagar, "in a little garden-house of Ranjit Singh's in the midst of a lovely grove of great extent, through whose dark-green boughs we have a splendid panorama of the snowy range to back our horizon. We have great projects of extending the canal by various branches to feed and fertilise the whole extent of the Doâb, which wants nothing but water to make it a garden, so fertile is the soil. . . The weather is perfect, so I am as happy as mere externals can make one."

A few days later he was staying at "a fine picturesque old castle or fort built by the Emperor Shah Jahân. Its lofty walls, with their turrets and battlements, enclose a quadrangle of the size of the great court of Trinity, while from the centre rises a dark mass of buildings three storeys high, forming the keep; presenting externally four blank walls pierced with loopholes, but within, arches and pillars and galleries with an open space in the centre, in which they all face. The summit rises sixty-four feet, which, in addition to the great elevation of the mound on which the castle stands, gives a noble view of mountain, river, and plain, covered with the finest timber and green with young corn; the whole backed by range on range, peak after peak, of dazzling snow." 
Two more of these ruined castles, all monuments of the taste and grandeur of the Mogul emperors, were visited in the course of Hodson's tour. "That Goth, Ranjit Singh," he writes, "and his followers have as much to answer for in their way as Cromwell and his erop-eared scoundrels in England and Ireland. They seem only to have conquered to destroy: every public work, every castle, road, serai, or avenue, has been destroyed; the finest mosques turned into powder-magazines and stables, the gardens into cantonments, and the fields into deserts."

Hodson one day came across an amusing instance of the way in which the Sikhs managed their fiscal affairs. He had been ordered to report on the accounts of revenue formerly collected in 180 villages along the Shah-Nahr, or Royal Canal. "By a convenient mixture of coaxing and threats, compliment and invective, a return was at last effected, by which it appeared that in ordinary cases about one-half the revenue reached the treasury, in some one-third, and in one district nothing! To my great amusement, when I came to this point, the gallant collector, a long-bearded old Sikh, quietly remarked, 'Yes, Sahib, this was indeed a great place for us entirely.' I said, 'Yes, you villain, you gentry grew fat on robbing your master.' 'Don't call it robbing,' he said; 'I assure you I wouldn't be dishonest for the world. I never took more than my predecessors did before me.' About the most naïve definition of honesty I have had the luck to meet with. I fancy our visit to these nooks and corners of the Punjâb has added some $£ 50,000$ a-year to the revenue." 
About this time he was surveying a part of the country lying along the left bank of the Ravi and below the hills. On March 14 he writes again from Dinanagar, whither he had returned after encountering one of those sudden storms of rain which transform a peaceful landscape into a wilderness of mud, stones, and water. The powerful breakwater which Napier's workmen had just built across a branch of the Chakar river was battered by the conquering flood until in two hours it became, said Hodson, "a thing of history."

In consequence of Hodson's report as to the amount of plundering that went on in his neighbourhood, a large party of horse was sent out under one of the principal chiefs to act upon the information thus supplied. "We have accordingly had a robberhunt on a large and tolerably successful scale. Numbers have been caught. One shot, pour encourager les autres, and we have traces of others, so that my quiet practice, originally for my own amusement and information, has been very useful to the State." He had discovered the greatest part of it by sending out clever fellows, disguised as fakeers, or religious beggars, to the different villages to talk to the people and learn their doings. "Some of the stories of Sikh violence, cruelty, and treachery which I have picked up are almost beyond belief. The indifference of these people to human life is something appalling. I could hardly get them to give a thought or attempt an inquiry as to the identity of a man whom I found dead, evidently by violence, by the roadside yesterday morning; and they were horrified at the thought of tying up or confining a sacred ox who had gored his thirteenth 
man the evening before last! They told me plainly that no one had the right to complain of being hurt by so venerable a beast."

Before the end of March Hodson received a letter from Sir Frederick Currie, then acting as Resident at Lahore, who invited him to "knock off his present work" and come into Lahore as quickly as he could. "I want to send you," he added, "with Mr Agnew to Multân. Mr Agnew starts immediately with your acquaintance, Sirdar Shamsher Singh, to assume the government of that province, Mulrâj having sent in his resignation of the Nizâmat. Lieutenant Becher is to be Agnew's permanent assistant, but he cannot join just now, and I wish you to go with Agnew. It is an important mission, and one that, I think, you will like to be employed in. When relieved by Becher, you will join the Guides at Lahore, and be employed also as assistant to the Resident. The sooner you come the better."

Hodson did knock off work at once, and hastened by forced marches towards Lahore. He was "much interested in the thought of going to so new a place as Multân,-new, that is to say, to Europeans, yet so important from position and commerce. The only drawback is the heat, which is notorious throughout Western India. I am not aware, however, that it is otherwise unhealthy. As you may suppose, I am much gratified by the appointment, both for its own sake and also as evincing so very favourable and kindly a disposition toward myself on the part of the new potentate."

A merciful Providence, however, saved Hodson from the cruel fate which presently overtook Mr 
Vans Agnew and his military colleague, Lieutenant Anderson, at Multân. By the beginning of April he had reached Lahore, where he met with a friendly greeting from Sir Frederick and Lady Currie, and once more tasted the delights of "loafbread, arm-chairs, hats, and ladies." There he found that the arrangement proposed by Currie "had already become matter of history, not of fact. The new one is still better for me. I am to remain at Lahore, and be an assistant to the Resident, liaving my Guide duties to discharge also when Lumsden arrives from Peshâwar with the corps."

The new Political "won't say anything of the regularity or consistency of making a man of two and a half years' service, and who has passed no examination, a political officer, nor will we be ungrateful enough to say that he is unfit for the appointment, but that he should do his utmost to show that the rule is more honoured in the breach than in the observance."

Pending the arrival of the Guides at Lahore, Hodson threw himself with his usual energy into the duties of his new employment. For six hours a-day he had to sit in court, "hearing petitions and appeals in all manner of cases, civil and criminal, and in matters of revenue. . . O One must be content with substantial justice as distinguished from technical law. In any point of difficulty one has always an older head to refer to, and meantime one has the satisfaction of knowing that one is independent and untrammelled save by a very simple code. Some things, such as sentencing a man to imprisonment for several years for killing a cow, are rather startling to one's ideas of right 
and wrong; but then to kill a cow is to break a law, and to disturb the public peace-perhaps cause bloodshed: so the law is vindicated, and one's conscience saved."

What spare time remained to him he employed in finishing a map which he had begun at Dinanagar, in translating official documents, and attending the darbârs. "When the Guides arrive on the 20th I shall have," he writes, "to assist in drilling and instructing them, to say nothing of seeing that their quarters are prepared, and everything ready for them. I am not, therefore, idle, and only wish I had time to read."

Meanwhile a storm was bursting which no one in India appears to have foreseen. On April $26 \mathrm{Hod}-$ son writes to his father from Lahore: "I mentioned to you that Sir F. Currie's plan of sending me to assist Agnew at Multân had been altered, and that Anderson had gone with him in my stead. At the time I was disposed to be disappointed; but we never know what is for our good. In this case I should doubtless have incurred the horrible fate of poor Anderson and Agnew. Both these poor fellows have been barbarously murdered by the Multân troops."

After giving a detailed account of their tragic fate and of the treacherous part played by Mulrâj himself, he adds: "The Sikh Darbâr profess their inability to coerce their rebel subject, who is rapidly collecting a large army, and strengthening himself in the proverbially strong fort of Multân. One cannot say how it will end. The necessary delay of five months, till after the rains, will give time for all the disaffected to gather together, and no 
one can say how far the infection may extend. The Sikhs were right in saying, "We shall have one more fight for it yet.'

The two Englishmen had been murdered on the 20 th of April 1848, and a few days later the brave Herbert Edwardes, from his frontier post beyond the Indus, began to collect the levies whom he was presently leading towards the scene of an outbreak which erelong became the centre of a widespread revolt against British tutelage over the Punjâb. On May 7 Hodson was writing thus from Lahore: "I expect to be busy in catching a party of rascals who have been trying to pervert our sepoys by bribes and promises. We have a clue to them, and hope to take them in the act. We are surrounded here with treachery. No man can say who is implicated, or how far the treason has spread. The life of no British officer away from Lahore is worth a week's purchase. It is a pleasant sort of government to prop up, when their headmen conspire against you, and their troops desert you on the slightest temptation."

In the same letter he asks his brother to procure for Lumsden and himself " a brace of good helmets" that would serve to protect them equally against "sun and blows"; something like the leathern helmet, "light, serviceable, and neat," then worn by the Prussian army. "We don't want ornament; in fact the plainer the better, as we should always wear a turban over them, but strong, and light as a hat."

This was the first of many commissions intrusted to the Rev. George H. Hodson in connection with the clothing and arming of the new Guide Corps. 
Lumsden had left such matters almost entirely in his subaltern's hands. The two men agreed in the choice of khaki, or dust colour, for the uniform of the Guides. With regard to the choice of weapons, Mr Hodson was requested to send out 300 carbines of a pattern to be selected by himself, which to his thinking "seemed scarcely a clerical business."

When the Guides arrived at Lahore very few of the men had firearms of any sort. The only weapons that any of them could boast of were old flint-muskets which had been in use for more than a quarter of a century. They had nerer been clothed in uniform, but wore their native dresses of various hues and shapes.

The result of these commissions proved so satisfactory that Sir Charles Napier, who in 1849 succeeded Lord Gough as commander-in-chief, pronounced the Guicles to be the only properly dressed light troops he had seen in India.

The conspirators whom Hodson had gone in search of were duly captured, and he "had the satisfaction of seeing them hung three days later." He then, in his own words, "tried a slight fever as a variety for two days." On May 14 he "started to bag the Rani, or queen-mother, in her abode beyond the Ravi, she having been convicted of complicity in the designs of the conspirators. Lumsden and myself were deputed by the Resident to call on her and intimate that her presence was urgently required. A detachment was ordered out to support us, in case any resistance should be offered. Fortunately it was not required, as the Rani complied at once with 
our polite request to come along with us. Instead of being taken to Lahore, as she expected, we carried her off to Kana Kutch, on the Ferozepore road, where a party of Wheeler's Irregulars had been sent to receive her. It was very hard work -a long night march to the fort (Shaikhopura), and a fourteen hours' ride across to Kana Kutch, whence I had two hour's' gallop into Lahore to report progress, making sixteen hours in the saddle, in May, when the nights are hot."

A few days later he was off again, at the head of some cavalry, to try and seize or disperse a body of horse and foot collected by a Sikh guru, or holy man, named Maharâj Singh. "I made," he writes on June 5, "a tremendous round by Amritsar, Bhairowal Ghat on the Biyas, and up that river's bank to Mukerian, in the Jalandhar Doâb, whence I was prepared to cross during the night with a party of cavalry and attack the rascals unawares." Everything promised well until Hodson found that the insurgent leader had been warned off by "a rogue of a native magistrate." Thereupon he "fairly bolted across the Ravi, and is now infesting the Doâb between that river and the Chinâb. I have scoured this part of the country, which my late surveys enabled me to traverse with perfect ease, got possession of every boat on the Ravi from Lahore to the hills, placed horsemen at every ferry, and have been bullying the people who supplied the saint with provisions and arms. I have a regiment of Irregular Horse (Skinner's) with me, and full powers to summon more, if necessary, from the Jalandhar Doâb. Meantime a party from Lahore are sweeping 
round to intercept the fellow, who is getting strong by degrees; and I am going to dash across at midnight with a handful of cavalry and see if I cannot beat up the country between this and Wazirabad."

"I am very well," he adds, "hard at work, and enjoying the thing very much. I imagine this will be the sort of life we shall lead about once a-week till the Punjâb is annexed. Every native official has fraternised with the rebels he was ordered to catch."

About this time Hodson received a long and characteristic letter from Herbert Edwardes, with whom he had lately been corresponding. The letter was dated May 24, from a small place on the right bank of the Indus, about three marches from Dera Ghâzi Khân. Edwardes begins by expressing his conviction that Sir F. Currie has "made a mistake beyond all present calculation in yielding to the commander-in-chief's wish to postpone hostilities for five months. Postpone a rebellion! Was ever such a thing heard of in any government? Postpone avenging the blood of two British officers! Should such a thing be ever heard of in British Asia? I read in the papers of enormous military preparations. Editors puff the advancing columns. You tell me of a future 25,000, men, fifty siege-guns, \&c., \&c., and all for what? Forsooth, to do nothing for five months!

"It is a burlesque upon politics, war, and government. Give me two of all these prophesied brigades, and Bahâwal Khân and I will fight the campaign for you while you are perspiring behind tatties 
in Lahore, and bottling up your British 'indignation ' at the slaughter of our countrymen. Action, action, action! Promptitude! these are the watchwords which constitute $i k b a l$ [prestige], and not the pusillanimous prudence and calculating indignation which are content to endure public insult for half a year. I quite blush for our position in the native eye, and am striving within my own humble sphere to throw a veil of little victories over it. What is so extraordinary, I can get no answer from Sir F. C. to any of my public letters or demi-officials representing the state of this frontier and the imperative necessity of securing Bahâwal Khân, if Mulrâj is to be kept from overrunning the whole country."

"I have just now," he continues, "galled Mulrâj to the quick by defeating his lieutenant, Longa Mal, at Ghâzi Khân, taking him prisoner with a gun, killing Chaitan Mal (Longa Mal's uncle) and forty others, including a Sikh subadâr of a regular infantry company. This has given us the fort of Dera Ghâzi Khân and a country of eight lakhs $(£ 80,000)$. The success should be followed up by Bahâwal Khân crossing the Satlaj, my crossing the Indus, and driving all Mulrâj's troops into the fort, after which you might wait as many months as you chose with both safety and dignity until you were ready for a siege. Every post I urge this to the Resident, and am quite sick of every post bringing no reply! Some extraordinary infatuation rests upon you all in Lahore. You talk quite coolly and at ease: 'Send away the queen' and 'breathe again'; 'trust I am now getting over the worst,'-and argue yourselves into the belief that 
'Mulrâj is in a bad way,' 'at a standstill,' and, in fact, on the eve of submission! Clearly you are under the thumb of some awful traitor whose interest it is to keep you in the dark. Mulrâj is daily adding to his means of resistance; digging up and mounting long-buried guns; enlisting on an average 100 men per diem; storming the fort ; clearing away houses round its base; collecting revenue, \&c., \&c. Is this the sort of 'standstill' you all contemplate for five months? ...

"While I write this the rebels are firing a salvo on the opposite side of the river, and have already fired nearly 100 rounds! Magazine is more plentiful with them than it is with me. You express a hope in your letter that the British Government will act for itself, and not prop up a fallen dynasty. In other words, you hope we shall seize the opportunity to annex the Punjâb. In this I cannot agree with you, for I think, for all that has yet happened, it would be both unjust and inexpedient. The treaty we made with the Sikh Government and people camnot be forfeited by the treachery of a Gurkha regiment in Multân, the rebellion of a discharged kardar, or the treasonable intrigues of the queen-mother, who has no connection with the Sikh Govermment of her son."

Events, however, were clearly tending to justify the policy which Hodson already deemed inevitable, and which Lord Dalhousie, the new GovernorGeneral, resolved a few months later to carry out. It is true that the treaty of Bhairowal had deprived the queen-mother of all direct authority in public affairs. But her power for mischief had not been lessened either by her seclusion at Shailhopura 
or her subsequent removal across the Satlaj. Her restless ambition made her the rallying centre for all the discontented spirits in the Punjâb. The outbreak at Multân was, in fact, the signal for a general Sikh uprising against the Power represented by Sir Frederick Currie at Lahore, and by a few British officers scattered throughout the country, from Major George Lawrence at Peshâwar to Lieutenant Edwardes in the south-west. In justice also to Currie himself it must be said that Edwardes's strictures fell wide of their mark. Before the end of April he had arranged for the prompt despatch of Sikh troops under their own sirdars to the scene of danger, rightly holding, as he wrote to Lord Dalhousie, that "a successful rebellion in Multân . . . would kindle a flame through the land which it would be very difficult to extinguish."

On the 10th of May he wrote to the GovernorGeneral expressing his entire concurrence with Lieutenant Edwardes "in what he says of the importance of an immediate move of troops on Multân, and regret as deeply as he or any one can do, that an expedition against Multân at this season is declared impossible." 1

When Lord Dalhousie in July granted the Resident a free hand, Sir F. Currie lost no time in despatching a British column to the support of Edwardes and the Nawâb of Bahâwalpur.

Meanwhile Hodson tells us in his letter of July 5 that he had been "fairly successful in obtaining information of the extent of the conspiracy, which has been keeping the whole country in a ferment these two months past. All that has occurred is

${ }^{1}$ Punjâb Blue-Book, 1847-1849. 
clearly traceable to the Rani, now happily deported, and her friends, and has been carried out with a fearful amount of the blackest treachery and baseness. There have been stirring events since I wrote last. Twice within a fortnight has Herbert Edwardes fought and defeated the Multân rebels in pitched battles, ${ }^{1}$ and has succeeded, despite of treacherous foes and doubtful friends, in driving them into the fort of Multân. His success has been only less splendid than the energy and courage which he has shown throughout, especially that high moral courage which defies responsibility, risks, selfinterest, and all else, for the good of the State, and which, if well directed, seems to command fortune and ensure success."

Hodson had then been summoned back to Lahore to take over the command of the Guides from Lumsden, who had been ordered down the river towards Bahâwalpur. He himself had made the journey of a hundred miles from Dinanagar, "with bag and baggage, in sixty hours, which, considering that one can't travel at all by day and not more than four miles by night, required a great amount of exertion and perseverance. It is strange," he adds, "that the natives always knock up sooner" than we do on a march like this. The cavalry were nine days on the road and grumbled then! I know few things more fatiguing than, when exhausted by the heat of the day, to have to mount at nightfall and ride slowly throughout the night, and for the two most disagreeable hours of a tropical day-viz., those after sunrise."

${ }^{1}$ On June 18 at Kinairi, on the left bank of the Chinâb, and on July 1 at Sadusain, a few miles from MIultîn. 
The heat at that time was terrible. One night, while he was making a longer march than usual, a British regiment on its way to Ferozepore suffered cruelly from the same hot night-wind which had completely prostrated himself. "It fell upon the men as they halted at a well to drink; they were fairly beaten, and lay down for a few minutes to pant. When they arose to continue their march, a captain and nine or ten men were left dead on the ground! It was the simoom of Africa in miniature." 1

1 Hodson of Hodson's Horse. 


\section{CHAPTER VII.}

THE SECOND SIKH WAR. 1848-1849.

ALL through July and August 1848 the blaze of an organised revolt spread wider and wider throughout the Land of the Five Rivers. Here and there in the outlying districts a few English officers still held their ground amidst a swarm of enemies concealed or open. While Edwardes and Lake were anxiously watching the movements of doubtful Sikh allies encamped beside them, and were clearing the ground for the force of all arms with which General Whish was about to open the regular siege of Multân, George Lawrence at Peshâwar, James Abbott in the Hazâra highlands, and John Nicholson in the country between Attock and Hasan Abdâl, were striving their hardest to keep back the flowing tide of Sikh rebellion. In Lahore alone a strong British garrison overawed the secret plotters and maintained the peace of the surrounding districts.

It was from the Sikh capital that Hodson wrote on September 3: "We have had stirring times lately, though I personally have had little share in them. Multân is at last invested, and we expect daily to hear of its fall. Meanwhile a new outbreak 
has occurred in Hazâra, a wild hilly region on the left bank of the Indus, above Attock, where one of the powerful sirdars ${ }^{1}$ has raised the standard of revolt."

In the same letter Hodson confided to his friends at home the fact that his countrymen had narrowly escaped "the effects of a general and well-organised conspiracy against British supremacy in Upper India. Our 'ally' Gulâb Singh, the creature of the treaty of 1846, the hill tribes, the whole Punjâb, the chiefs of Rajputana, and the states round Ambâla and Karnâl, and even the King of Kabul, I believe, have been for months and months securely plotting, without our having more than the merest hints of local disturbances, against the supremacy of the British Government. They were to unite for one vast effort and drive us back upon the Jumna. This was to be again the boundary of British India. The rising in Multân was to be the signal. All was prepared, when a quarrel between Mulrâj and the treacherous khan, Singh Mân, who was sent to commence the war, spoilt their whole scheme. The proud Rajput, Gulâb Singh, refused to follow in the wake of a Multân merchant, and the merchant would not yield to the soldier. We have seen the mere ebullitions of the storm, the bubbles which float at the surface. I believe that now we are safe from a general rising, and that the fall of Multân will put a stop to mischief. . . . Absolute supremacy has been, I think, long demonstrated to be our only safety among wild and treacherous

${ }^{1}$ Chatar Singh, father of Rajah Sher Singh, who had been sent with a strong Sikh force to co-operate with Edwardes against Mulrâj. 
races. Moderation, in the modern sense, is the greatest of all weakness."

Early in September our guns fired their first salvo against the walls of Multân. By the middle of the month, however, Sher Singh, whose loyalty had long been suspected, had marched off at the head of 5000 Sikh troops, and six guns, to make common cause with Mulrâj, and proclaim a kind of holy war against the cow-killing infidels who had imprisoned his queen, and sat in the high places once filled by the barons and councillors of Ranjit Singh. Owing to his defection General Whish found himself compelled to raise for that present the siege of Multân and await the arrival of further reinforcements.

In this state of affairs it was deemed advisable at Lahore to get secure possession of the strong fort of Govindgarh, overlooking the populous city of Amritsar. "I have just despatched every available Guide to try and get quietly into the far-famed fort of Govindgarh, and hope in a few hours to hear of their success. They have forty friends inside and only a few score wavering enemies."

A few days later he writes: "My Guides have covered themselves with glory (and dust) by the way in which they got into, and got possession of, the famed fort of Govindgarh. A hundred of my men, under a native officer,- - a fine lad of about twenty, whom I have petted a good deal,-went up quietly to the gates on pretence of escorting four State prisoners whom I had put in irons for the occasion, were allowed to get in, and then threw up their caps and took possession of the gateway, despite the scowls, and threats, and all 
but open resistance of the Sikh garrison. A day afterwards a regiment marched from Lahore and went into garrison there, and so Ranjit Singh's treasure-fort is fairly in our hands." The effect of this timely movement was declared by Lord Dalhousie, who had been, indeed, the first to suggest it, "to have placed us in a commanding position in the most disaffected district in the Punjâb." ${ }^{1}$

Before the close of September Hodson with a party of his Guides was encamped at Râmnagar on the left bank of the Chinâb, where he hoped to meet the wife and children of Major George Lawrence and escort them safely to Lahore. On learning the nerws of Sher Singh's treachery Major George Lawrence had sent off from Peshâwar Mrs Lawrence and her two little children under the charge of Sultân Muhammad Khan, an Afghan chief, who had sworn upon the Korân to carry them unharmed to the British Residency.

This man, however, proved to be a traitor of the darkest Afghan dye. He showed his gratitude to his old benefactor, Henry Lawrence, by detaining the brother's family under strict guard in his own castle at Kohât, whence some weeks later they were transferred as hostages to the camp of his fellowtraitor, the wily old sirdar, Chatar Singh. Hodson therefore, after six days' waiting about Râmnagar, found that he had gone, like John Nicholson and Reynell Taylor, on a bootless errand. He was suddenly recalled to Lahore by an order which reached him on the evening of the 5 th. "I started," he says, "at sunset, and pushing my way on various borrowed steeds across that dreary region during the

${ }^{1}$ Punjâb Blue-Book, 1847-1849. 
night, accompanied by a single camel-rider, I reached Lahore, a distance of seventy miles, by nine the following morning."

On the 8th he was "off again at daybreak on a longer journey still, having to cross the country to Brigadier Wheeler's camp in the Jalandhar Doâb, to convey orders to him relative to the reduction of two rebellious forts in the Doâb between the Ravi and Biyas. A 'grind' of some twenty-six hours on camel-back, with the necessary stoppages, took me to the camp, whence (because I had not had enough) I recrossed the Biyas the same night, after examining and reporting on the state of the ferries by which the troops were to follow me. This time I was escorted by a troop of Irregular Horse, being thereby, according to my estimation of Sikh prowess, rendered tolerably independent."

Next morning he marched to the fort of Rangar Nagal, some fourteen miles from the right bank of the Biyas. His approach was greeted by a fire of matchlocks and wall-pieces, which enabled him to mark the exact range of the enemy's guns. $\mathrm{He}$ "lost no time in getting the horsemen into a secure position (which means, one equally good for fighting or running away), and advanced under shelter of the trees and sugar-canes to within easy distance of the fort. Hence I despatched a message to the rebels, to say that if they did not come to reason within an hour they should have no choice but that between cold steel or the gallows. The hour elapsed without result, so mentally consigning the garrison to annihilation, I set to work to reconnoitre the ground round the fort. This accomplished, with no further interruption than a shower of unpleasant bullets 
when I veṇtured too near, I sat down and drew a little pencil plan of the ground and fort, despatched a trooper with it to the brigadier, and then retired to a little village about a mile off for the night. Another day and night passed in this precarious fashion without (as is my usual fate) servants, clothes, or traps, until at length my own men (Guides) arrived from Lahore with my baggage and horses. I could now muster 100 rifles and 80 horsemen, so we set to work to invest the place, being the only way to render the escape of the rebels difficult or impossible. The fort, though very small, was immensely strong, and well garrisoned with desperadoes, and we had sharp work of it during the two mights and day which elapsed before the brigadier appeared with his troops. By keeping my men scattered about in parties, under cover, the superiority of their weapons enabled them to gall the defenders of the fort whenever they showed their heads, day or night, and whenever they made a sally they got driven back with the loss of one or two of their companions. At last the brigadier appeared, pounded the place with his guns during the day, and let the garrison escape at night."

The following week was spent in the work of destroying the empty fort, by means of forty-one mines loaded in all with $8000 \mathrm{lb}$. of powder. Hodson's services on this occasion were gratefully acknowledged by Brigadier Wheeler in his despatch of October 15 : "Lieutenant W. S. Hodson, with his detachment of the corps of Guides, has done most excellent service, and by his daring boldness, and that of his men, gained the admiration of all."

Wheeler's next morement was directed against 
the fort of Morâri, on the left bank of the Ravi, a few miles north-west of Dinanagar. He had hoped that Major Fisher, acting in concert with Hodson, would be in time to prevent the escape of the enemy; but Fisher was too late for such a purpose. On the night of the 24th the rebels, says Hodson, "bolted before he [the brigadier] fired a shot. . . . I have had loads of work," he adds, " what with soldiering, providing supplies for the force, and all the multifarious duties which come on the shoulders of a 'political' out here. I am quite well, and the weather is lovely, so work is easy comparatively, and an active life like this is, as you know, my particular weakness."

In the last days of October the leading brigades of Gough's army of the Punjâb had marched past Lahore across the Ravi to the camping-ground at Shahdara, where, on November 3, 7000 good troops were assembled, eager to move forward under the best of Gough's cavalry leaders, Brigadier-General Cureton. By the 21st Lord Gough himself was encamped ten miles from Ramnagar, at the head of some 16,000 troops of all arms, preparing to drive the enemy across the Chinâb. Hodson had hoped to cross the Ravi and join the commanderin-chief. "We want Sir Charles Napier sadly," he wrote. "What with the incapacity shown at Multân, and the dilatory proceedings at headquarters, our reputation is suffering cruelly, and every one knows that that is a stain only to be dyed out in blood. Every week's delay adds thousands to our present foes and future rictims." But his energies were still "confined to a space bounded by the Chinâb and the Biyas, and a line 
drawn east and west through Amritsar and Lahore. Nearly the whole of this vast tract of country has been under my sole charge. I have had also to feed an army daily of 3000 odd fighting men, 2000 odd horses, and 14,000 to $15,000 \mathrm{camp}$ followers. Also to take care of and work my Guides; to point out the haunts and obtain information of the strength of 'the enemy,' and give him over to the tender mercies of fire and sword."

On the 8th of November he marched from Dinanagar to overtake Wheeler's column and accompany it across the Ravi. On reaching that river he tried in vain to persuade the brigadier to march against a party of insurgents who were only fourteen miles off. Wheeler was intent on pushing on to join the main army. About half way on the march towards Ramnagar Hodson "rode over to Lahore and talked to Sir F. Currie, who was just despatching an express to me about these very people we had left unattacked two days before. He sent me off there and then to see the commanderin-chief, who was very polite; asked my opinion (and acted on it too!); told me all his plans for carrying on the war; and on my telling him the facts of the case, sent an order to the brigadier to retrace his steps and attack the party he had passed by at once, with something very like a rap orer the knuckles."

After a delay of several days, caused by a counterorder to reinforce General Colin Campbell, Wheeler was allowed to march towards the fort of Kalallwâla, in the Rechna Doâb, ${ }^{1}$ not far from Pathankôt.

1 The Doâb between the Ravi and the Chinâb. 
By the 20th Wheeler's force had got within two marches of the place aforesaid. In spite of Hodson's urgent entreaties the brigadier was for moving forward so slowly that Hodson felt himself " compelled to out-manœuvre him by a bold stroke." On the following morning he pushed on ahead with his Guides about ten miles to a fort held by a doubtful Sikh sirdar. He had with him only 100 men, while the enemy "was only eight miles off with 4000-rabble, to be sure, and fellows who have no heart for fighting."

In a moment Hodson's mind was made up, and here he must tell his own story: "I therefore 'boned' the chief's two confidential servants, who were in his dwelling-house outside the fort, and taking one on each side of me, walked up to the gateway and demanded admission; they hesitated and made excuses. I significantly hinted that my two companions should be responsible if a shot was fired; the stout Sikh heart failed, and I was admitted. My proceeding was justified, and rendered most opportune, by the discovery that the garrison were preparing munitions of war, mounting guns, and looking saucy. I turned them out by the same means as I had gained admittance-viz., by hinting that if any resistance was made the headmen by my side were doomed. Putting in sixteen of my Guides to hold it until further orders, I took up my quarters outside for the night, and prepared to attack another small mud fort near at hand in the morning.

"However, my friends ran away in the night in a fright, and thus I had opened the road to Kalallwâla without firing a shot." 
On the morning of the 22nd Hodson resumed his march, sending a messenger back to the brigadier begging him to come on with all possible speed to his help. The brigadier, he writes, "was dreadfully angry, but came on like a good boy! When within a mile or so of the fort I halted my party to allow his column to get up nearer, and as soon as I could see it, moved on quietly. The ruse told to perfection: thinking they had only 100 men and myself to deal with, the Sikhs advanced in strength, thirty to one, to meet me, with colours flying and drums beating. Just then a breeze sprang up, the dust blew aside, and the long line of horsemen coming on rapidly behind my party burst upon their senses. They turned instantly and made for the fort, so leaving my men to advance quietly after them, I galloped up to the brigadier, pointed out the flying Sikhs, explained their position, and begged him to charge them."

The brigadier "melted from his wrath and told two regiments of Irregulars to follow my guidance. On we went at the gallop, cut in amongst the fugitives, and punished them fearfully. The unfortunate wretches had cause to rue the day they turned rebels, for we left them thickly on the ground as we swept along. I have never charged with cavalry before, or come so directly into handto-hand conflict with the Sikh, save of course in the trenches at Sobraon. About 300 to 400 escaped into the fort, while the remainder threw down their arms and dispersed over the country."

The remnant of the garrison fled in the night, their loss in slain alone during the attack and the subsequent pursuit amounting to 300 . From the 
village adjacent to the fort a large body of the enemy had been dislodged, wrote the brigadier, "by the detachment of the corps of Guides in good style, killing several." " "Since then," writes Hodson, "we have been pursuing other parties, but only came into collision with them to a very trifling extent once. They had learnt how to run away beautifully. The brigadier has grown quite active, and very fond of me since that day at Kalallwâla, though he had the wit to see how very 'brown I had done him' by making him march two marches in one."

Hodson himself received the special thanks of Brigadier-General Hugh Wheeler, "not only for his services in the field, but for the information with which he furnished him."

In the letter from which we have already quoted Hodson draws a lively picture of the duties devolved upon him as a political officer in command of a body of the Guides: "Item, fighting personally; item, to destroy six forts, and sell by auction the property therein found ; item, to be civil to all comers; item, to report all the said doings daily to Government; item, to march ten to twenty miles a-day at a slow pace; item, to eat, drink, dress, and sleep, to rest oneself from all these labour's. In the above compendious epitome of the work of that much-abused and ill-used class called 'politicals' in India, you will, I trust, observe no vacant places or hiati in which you would expect to see inscribed, 'Item, to write to one's friends." "

Meanwhile several bands of insurgents continued ravaging the country between the Ravi and Chinâb.

${ }^{1}$ Punjâb Blue-Book, 1847-1849. 
Hodson dashed at these marauders whenever he got the chance. Before the middle of December, as soon as he had established some kind of order about Dinanagar, he was once more across the Ravi on the track of a rebel party headed by two petty Sikh sirdars, who had been busily plundering the country at the foot of the hills near Sialkôt. On the evening of the 15th he learned that some 500 of the insurgents were within his reach at Gamrola, near Zafarwâl, some twenty-five miles off. There were so many spies in his camp that he allowed his men to turn in as usual for the night. Soon after midnight, however, he aroused his little party and "got them under arms and off before any one was aware of our move. I had with me 100 of my Guides and 15 sowars."

Marching all night, he came upon the insurgents at daybreak. Halting the Guides under cover of a small wooded village, he himself went forward to recomnoitre, and "found the eneny drawn up to the number of from 150 to 200 horse and foot on the north side of Gamrola, between the village and a large tank." Just then, however, they were joined by a party from Baddi-Pind, and the whole fell back to the bank of a wide nullah which ran along their rear. Besides his fifteen sowars he was now accompanied by a party of Sikh horsemen, of whose fidelity he was more than doubtful. In order at once to get rid of these and mislead the enemy as to the strength of his own party, Hodson instructed them to prevent the enemy from getting into the villages or hiding among the sugar-canes on his flanks.

$\mathrm{He}$ was still awaiting the arrival of his Guide infantry, who were now close at hand. Within 
five minutes, however, the insurgents "moved off sulkily like a herd of frightened deer, half alarmed, half in doubt. I saw at once that there was but one chance left, and determined to go at them as I was, though 15 to 150 is an imprudent attempt." Crossing the nullah-bed at a trot, Hodson's horsemen fired one volley. Then throwing their matchlocks aside, they dashed at the retiring enemy. "The greater part instantly fled precipitately, but a number of Akalies [or fanatics], seeing that they had no chance of escape on foot, turned and fought with desperation. One man in particular succeeded in keeping four sowars at bay for some minutes, and was only mastered after a severe struggle." ${ }^{1}$

Such is the story told by Hodson in his official letter to his political chief, Sir F. Currie. "The affair at Baddi-Pind," wrote Sir F. Currie to the Governor-General, "was a most gallant one, far more so than Lieutenant Hodson's modest statement in his letter would lead one to suppose. I have had accounts of it from parties who were eyewitnesses to the personal gallantry and energy of Lieutenant Hodson, by whose hand, in single conflict, the Akali fell, after he had beaten off four of the sowars of the 15th Irregulars; and to whose bold activity, indefatigable exertions, and the admirable arrangements made by him, with the small means at his disposal, the successful issue of this excursion is to be attributed." 2

1 Punjâb Blue-Book.

2 Ibid. With regard to this affair Sir H. Lawrence had written to Sir F. Currie: "Mr Hodson's affair seems to be a most gallant one, very modestly told. Pray make an official report of it, that he may get the kudos which is due to him ; his name has been often before me, and always honourably." 
The following passage in one of Hodson's private letters will serve to fill up the outline thus sketched by the Resident himself: "The mounted men got off, but a party of Akalies on foot stopped and fought us, in some instances very fiercely. One fine bold 'Nihung' beat off four sowars one after another, and kept them all at bay. I then went at him myself, fearing that he would kill one of them. He instantly rushed to meet me like a tiger, closed with me, yelling, 'Wah Guru-ke jai!' and accompanying each shout with a terrific blow of his tulwar. I guarded the three or four first, but he pressed so closely to my horse's rein that I could not get a fair cut in return. At length I pressed in my turn upon him so sharply that he missed his blow, and I caught his tulwar backhanded with my bridle-hand, wrenched it from him, and cut him down with the right, having received no further injury than a severe cut across the fingers. I never beheld such desperation and fury in my life. It was not human scarcely."

By that time the rest of the insurgents had got so far away that Hodson did not deem it prudent to chase them any farther "in the face of a hostile population, who came out of the villages, with arms in their hands, which, though nominally brought against the insurgents, might at any moment have been turned against us. My sepoys, too, had followed me at a run for more than a mile, which in addition to their long march had exhausted them greatly." He was therefore obliged to halt, "not without a growl at General Wheeler for having left me without any men. We had killed one more than our own number, however, and five more 
were so severely wounded that they were removed on charpoys."

The fort of Baddi-Pind was levelled to the ground. Next morning at daybreak Hodson continued the pursuit. Shortly after noon he sighted a body of insurgents near Cherauk, but they had gained so long a start of him that after a gallop of three miles he was fain to give up the chase. "I regret extremely," he wrote to the Resident, "that I had not had a larger party of cavalry with me. Had I been accompanied by even a single troop, I think it is not too much to say that the whole of the leaders of these bands of marauders would have been either killed or taken prisoners."

The enemy, however, had no heart for further fighting. In the same letter of December 23 from which I have just quoted, Hodson was able to report to Sir Frederick Currie that after his last encounter they "only halted for a few hours at a time to collect their scattered followers and cook their food, and hurried to the upper ferries of the Chinâb, which the last of the party crossed early on the 20th. I have ascertained satisfactorily that there are no insurgents in arms on this side the Chinâb, and I have made some progress in reducing these districts to order." 1

Nor was Lord Dalhousie slow on his part to indorse Currie's eulogies of his dashing subaltern. Addressing the Resident through his own secretary, Sir Henry Elliot, on January 14, 1849, the Governor-General conveyed to Lieutenant Hodson "the strong expression of his satisfaction with his conduct, and with the mode in which he discharges

1 Punjâb Blue-Book. 
whatever duty is intrusted to him. The GovernorGeneral has had frequent occasions of noticing the activity, energy, and intelligence of his proceedings, and he has added to the exercise of the same qualities on this occasion an exhibition of personal gallantry which the Governor-General has much pleasure in recording and applauding, although Lieutenant Hodson has modestly refrained from bringing it to notice himself. The GovernorGeneral offers to Lieutenant Hodson his best thanks, for these services." 1

Meanwhile events in the Punjâb were steadily advancing towards the issue which Hodson had been among the first to foresee. By the middle of December the bulk of Gough's army was halted some miles beyond the Chinâb about Hela, awaiting Dalhousie's permission to attack Sher Singh, who had fallen back from the line of the Chinâb to a strongly intrenched position near the Jhilam, behind the jungles of Chilianwâla. Peshâwar was already occupied by Dost Muhammad's Afghans. James Abbott still held his own in the wilds of Hazâra. But thousands of good Sikh troops were marching from the Indus to the Jhilam under the standard of Sher Singh's father, Chatar Singh. Nicholson's efforts to hinder his advance had proved utterly futile for want of timely aid from Gough's troops.

In the last days of December General Whish found himself strong enough to press forward the siege of Multân with so much vigour that by January 2,1849 , the whole of the city outside the citadel had fallen into his hands. On the 3rd of

1 Hodson of Hodson's Horse. 
the same month the strong fortress of Attock opened its gates to the Amir of Afghanistan, and its brave defender, Lieutenant Herbert, subsequently became, like George Lawrence, a prisoner in the hands of Chatar Singh.

The good news from Multân induced Lord Dalhousie, then staying at Ferozepore, to loosen somewhat the curb he had placed upon his impetuous commander-in-chief. What use the brave old soldier made of his chief's concession may be seen from the following passage in Hodson's letter of January 18: "We have just received intelligence of another great fight between the army under Lord Gough and the Sikhs, in which the latter, though beaten, seem to have had every advantage given away to them. Our loss has been severe, and the mismanagement very disgraceful, yet it will be called a victory and lauded accordingly. Oh, for one month of Sir Charles Napier!"

The bloody battle of Chilianwâla, which resulted in a doubtful victory purchased at a terrible cost, was fought on January 13. About a fortnight earlier Lumsden and Hodson had marched off with a strong party of the Guides, horse and foot, in pursuit of an insurgent force moving along the foot of the hills that border the districts of Nurpur and Pathankôt. So swift and secret were the movements of the Guides that parties of Sikhs were caught in the act of cooking their dinners under a clump of trees. At sight of Hodson's advancing infantry they turned and fled. But Lumsden's horsemen were close upon their heels. In spite of the broken and marshy ground, the runaways were cut up almost to a man. "So bad," says Hodson 
in his report of the affair, "was the nature of the country over which he [Lumsden] followed them, that at one time more than half the horses of his troops were down, pursuers and pursued rolling together in desperate strife in the middle of the deep marshes. From thirty to forty of the enemy were killed or mortally wounded, among whom we were able to identify beyond doubt the insurgent leaders, Ganda Singh, and his major, Sukha Singh." 1 The loss of the victors in this dashing affair was confined to one horse killed and one wounded. As a matter of course they received the thanks of the Indian Government.

A few days later Hodson was again in the field, employed on behalf of General Wheeler in hunting after Ram Singh, who was again trying to raise the hill country north of Jalandhar against its new masters. "I have been day and night at work," he writes, "examining the hills and rivers, trying fords, leading columns, and doing all the multifarious duties thrust on that unhappy combination of hard work, a 'Guide' and 'Political' in one." The rebel leader was found to be strongly posted on the Dalla mountain. On the 15th Hodson, acting on Wheeler's instructions, led his Guides and a wing of the 3rd Native Infantry up the right bank of the Ravi with a view to recross the river and move up to a high peak of the mountain, while two other columns advanced from opposite quarters to the attack. "We had to march," writes Hodson, "by a circuitous route across the hills; darkness came on, accompanied by dreadful rain, the rivers rose and were impassable, and after twenty-four hours of

1 Punjâb Blue-Book. 
the most trying work I ever experienced, in which cold, hunger, and wet were our enemies, we succeeded in reaching our ground just in time to be too late." On the morning of the 16th the remaining columns succeeded in storming the position with no great loss. Ram Singh once more fled across the Ravi, with only two followers; and Lieutenant Hodson, in the words of Wheeler's despatch, "has entitled himself to the sincere thanks of the brigadier-general for his endeavours to lead a column to turn the enemy's position, which failed only from causes which rendered success impracticable."

On January 31 Hodson's amazing energy saved him from an untimely end. He had gone into Lahore for a few days to see Sir Henry Lawrence, who had just resumed his post as Resident. He left Lahore on the morning of the 31st, on his way back to Dinanagar. Halting for breakfast at Amritsar, he reached his camp by nightfall, having covered the hundred miles in ten hours and a half. "A party of Sikhs," he writes, "had collected at a village by the roadside to attack me and polish me off." They had not expected him, however, till the next morning. "I am sorry to say," he adds, "that they surrounded my horses, which were coming on quietly in the morning, asked for me, and finding I had escaped, stole my best horse, a valuable Arab, who had carried me in three fights, and bolted, not, however, without resistance, for two horsemen (Guides) of mine who were with the horse tried to save it. One got four wounds and the other escaped unhurt. Had I ridden like any other Christian instead of like a spectre horseman, and been the usual time on the 
road, I should have been a "body." "As soon as the tidings reached us," he says in a letter to $\mathrm{Mr}$ Lewin Bowring, "the troop was off like a flash of lightning, old Fathi Khan going at the gallop the whole distance and sending a man to us-we were at breakfast at the time in camp-to say that he was off! We followed like a steeplechase, got up to the scene of the scrimmage, some five kôs hence, and did our best to trace the rascals. We got on their track and followed it to Kanowan, but there lost all trace of them, and as a matter of course not a soul would own to having seen them. . . . I have had enough of riding-100 miles on the 31 st, and eleven hour's steady in the saddle on the 1st! I only feel it in the waist, which is somewhat sore from the constant pressure of a sword-belt for so many hours."

$$
\begin{aligned}
& \text { " "But my horse it is another's, } \\
& \text { And it never can be mine,", }
\end{aligned}
$$

were the words in which Hodson, writing to his father, gave a humorous turn to the feeling of "intense disgust" expressed in his letter to $\mathrm{Mr}$ Bowring at the abduction of his favourite Arab, who had done him "yeoman service" during the campaign.

On January 22 the citadel of Multân surrendered to General Whish, and to Herbert Edwardes was intrusted the duty of escorting Mulrâj as prisoner to Lahore. Three of Whish's brigades were at once sent northwards to reinforce Gough, who had meanwhile halted at Chilianwâla, watching Sher Singh's army intrenched about Rasûl. By the middle of February the combined forces of Sher and Chatar Singh marched quietly round Gough's flank towards the 
Chinâb near Wazirabad in hopes of intercepting Gough's reinforcements, and even, it was said, of making a dash at Lahore. By this time Hodson found himself acting in close companionship with the army of the Punjâb. "I am at present with my men," he writes on February 19 from Wazirabad, "attached to a brigade encamped on this (the left) bank of the Chinâb to prevent the enemy crossing until Lord Gough is ready to attack them on the right bank, where he is now encamped with his whole force minus our brigarle."

Baffled by swollen fords and British vigilance in their attempts to cross the Chinâb, the Sikh leaders prepared to make their last stand round the walled city of Gujarât, on the right bank of the Chinâb, some miles north of Wazirabad. In front of this place some 50,000 horse and foot, including 1500 Afghans, with an armament of 60 guns, awaited Lord Gough's advance at the head of 23,000 men and 90 guns.

On February 21, 1849, the British general fought and won "his last battle and his best," as he himself put it in his letter to the chairman of the India Board. At 8.30 of that morning the battle of the guns began, and raged more or less fiercely for about three hours. By that time the two villages on our right front had been stormed, and about noon the long British line moved forward to certain victory. The retreat of the enemy was soon turned by our guns and cavalry into a murderous rout. That day the whole of their standing camp, their baggage, ordnance stores, and fifty-three of their guns fell into the victor's hands. Gough's whole loss in killed and wounded amounted only to 806 men. 
At this crowning victory of Gujarât Hodson himself was present as an active member of Lord Gough's personal staff. Of his letter describing the battle no trace can be found, nor did his name at first appear in Lord Gough's despatch to the Governor-General. This oversight, however, was duly remedied in Lord Gough's postscript of March 15: "On the reperusal of my despatch relative to the operations of February 21 at Gujarât, I regret to find that $I$ omitted to mention the names of Lieutenants Lumsden and Hodson of the corps of Guides, and Lieutenant Lake of the Engineers, attached to the Political Department. These officers were most active in conveying orders throughout the action, and I now beg to bring their names to the favourable notice of your lordship." 


\section{CHAP'IER VIII.}

FROM SOLDIER TO CIVILIAN. 1849-1850.

ON the morning of February 22 a strong flying column of all arms, led by the dashing Sir Walter Gilbert, set out from the field of Gujarât on that long hot chase of the routed enemy which led to the final surrender of the Sikhs at Rawal Pindi, and encled a week later in the flight of Dost Muhammad's horsemen through the Khaibar hills, only a few hours before Gilbert's cavalry reached Peshâwar. On March 30, 1849, the Marquis of Dalhousie issued the proclamation which dethroned the child-sovereign of Ranjit's lingdom, and turned the Punjâb into a province of British India.

"I had anticipated and wished for this measure," wrote Hodson on April 17. "I did not, however, expeet that it would be carried out so suddenly and so sweepingly as it has been. I have been annexed as well as the Punjâb. My 'occupation's gone." "

In other words, under the new scheme of government provided by Lord Dalhousie for the Punjâb, Lieutenant W. Hodson was relieved for the monent of his civil duties by some one whose official rank entitled him to displace a mere subaltern of less 
than five years' standing. Conscious of his own worth, as attested by the records, public and private, of his recent services, he fell back, with a passing grumble, upon the post he still held as second in command of the Guides under the high-souled Harry Lumsden. After instructing the new Commissioner in the details of the province, which he himself had won from the rebels during the past six months, he rejoined the Guides at Peshâwar to arrange with Lumsden the proposed additions to the strength of that corps.

"Now daily, morning and evening," he writes in June, "I may be seen standing on one leg to convince their Afghan mind of the plausibility and elegance of the goose-step. I am quite a sergeantmajor just now, and you will well believe that your wandering brother is sufficiently cosmopolised to drop with a certain aplomb into any line of life which may turn up in the course of his career. I was always fond of 'soldiering;' and there is a species of absurdity in dropping from the minister of a province into a drill-sergeant, which is enlivening."

Meanwhile Hodson, as he tells his brother, had "made some progress in the knowledge of men," but found himself behindhand in that of books. "We are sadly off," he writes, "for military works in English, and few sciences require more study than the art of war. You might get me a list of good works from the United Service Institution at Charing Cross. I want the best edition of Crasar procurable; also Xenophon and Arrian. I fancy the last has been very well edited." In the matter of reading he was certainly better off than most of the many officers then quartered about the 
frontier; but he had read the few books he always earried about with him until he was tired of them all excepting Shakespeare. "Then, of course, there are no ladies here, and consequently no society, or réunions (as they are called when people live together), and people are pitched headlong on to their own resources, and find them very hard falling indeed!"

He was just then recovering from a sharp attack of fever- " a regular blazing Eastern fever, the sort of thing which burns so fast that if it don't stop quickly, it burns you well down into the socket, and leaves you there without strength to splutter or flicker, and you go out without the satisfaction of a last flare-up at expiring." By this time the order had come for increasing the Guide corps to 1000 men, so that Hodson would have plenty of work before him, especially as Lumsden left " almost everything" in his lieutenant's hands. By this time also his good friend, Sir Henry Lawrence, had obtained for him the post of Assistant Commissioner under the new Board of Administration, at the head of which was Sir Henry himself.

On this occasion one of his heartiest well-wishers was his late comrade and commander, Harry Lumsden. "I congratulate you," he wrote in July, "on being made an Assistant Commissioner in the Punjâb, though I am myself truly sorry to lose you as a Guide: however, it is for your advantage, no doubt."

Some months earlier the new President of the Punjâb Board had not been in the best of humours either with Hodson or Hodson's commandant. To the former he had written on February 28: "I 
am seriously displeased at the way you and Lumsden have behaved after all my injunctions. Battles are not fought every day, and yet to this moment I have not one line from either of you, the two officers of the Guides, on the subject of a general action fought on the 21st." And on the following day, after giving Hodson some directions as to the treatment of some prisoners, Sir Henry wrote: "I know you are zealous, and I am ready as ever to appreciate your merits, but it seems to me that a year has not lessened the great defect in your character and drawback to your usefulness -viz., impetuosity and excess of self-reliance."

Sir Henry, indeed, was just then out of humour with things in general, especially with Dalhousie's plans for annexing and governing the Punjâb. His broken health and his strained relations with a Governor-General who had a will of his own did not tend to improve a temper naturally quick to take offence, and now yet more embittered by the fact of his holding only the first place in a board of three, one of whom was his brother, John Lawrence. In Hodson's ease, however, this splenetic humour does not seem to have rankled long. In due time Sir Henry frankly owned that he had misjudged his young friend, and Hodson's soreness at the seeming injustice ere long gave place to kindlier feelings and a juster sense of his patron's unfailing efforts on his behalf. Sir Henry's letters of this period show how warm an interest he took in Hodson's fortunes. Writing from Lahore on July 21 to congratulate Hodson on his pucka appointment, he says: "Regarding your appointment, I had to speak or write at least six times since I went to 
Simla. You can come down with Lumsden or otherwise as you and he think best... . If you come down, the sooner the better, for I have a special bit of service in this direction for the Guides which must come off soon. . . . You never sent me the memorandum of services during the war." 1

About the middle of August Hodson had reached Lahore and entered on the duties of Assistant to the Commissioner, Charles B. Saunders. He had hardly set to work when he came in for another sharp attack of fever. "I am about again," he writes on September 3, "but not able to work. Sir H. Lawrence is very unwell: I fear that his constitution is utterly broken down, and that he will either have to go away from India for two years or more, or that another hot season will kill him. He is ten years older in every respect than he was during our Kashmir trip in 1846."

With regard to the nature and extent of his duties the new Assistant Commissioner had not much to learn. They combined, in his own words, "judicial, police, magisterial, and revenue work. A goodly number of new ideas, is it not? Happily I have tried all under the old régime, and have only to learn the new system and official slang. It will be a good line eventually. At present I get less pay than with the Guides since their augmentation."

It was not entirely of his own choice that Hodson had entered upon his new career. "To tell the truth," he wrote on September 24, "I had much rather have remained with the Guides,-a more independent and very far pleasanter life, and I ${ }^{1}$ Letters supplied by Miss Hodson. 
think one that will in the end be more distinguished. However, I was guided by Mr Thomason's and Sir H. Lawrence's advice, and must take the consequences."

There were other matters, also, on which for the moment he was specially employed. "The army has fallen to my share, and I have to examine into the claims of innumerable fine old hangers-on of the Lahore State to grants or pensions, to record their rights, and report on them for the decision of Government. Then there are upwards of 2000 old women, wives and mothers of soldiers killed in war, whom I have to see and pay the pittance decreed by their masters. Lord Dalhousie and his secretaries and officials are stern and hard taskmasters, and are not unworthily represented by the new Board, the only merciful member of which (Sir H. Lawrence) is left in a minority, and is, moreover, too ill to do much."

In October Hodson was again disabled for a time from active work. For several weeks he was, in his orwn words, "continuously bedridden, thanks to a rampageous horse. Gentlemen at home ride trained and broken horses; we ride fresh young brutes innocent of bit or saddle till the day one mounts them, and it's not one wild trick but a thousand they have. But my leg is doing well, only sprained; but three weeks on one's back is hard lines when, as now, it means solitary confinement. "Tis true an acquaintance now and then drops in, and the doctor's visits mark the lapse of days, but at the best it is weary work."

During those weeks of enforced idleness he amused himself with reading the Life of Sir T. 
Fowell Buxton, whose energy, he wrote, "is admirably shown in everything, from porter and beefsteaks to bullying West Indian planters. We want men of that kind out here, who will stand climate and snubbing to any amount. The apathy and laissez-faire system which the climate of India seems to engender is quite astounding; but one gets used to it soon, and in time, I suppose, as apathetic as the rest of them. Sir Henry Lawrence is still absent on his tour. . . He seemed to me utterly broken up, body and mind, when he was here."

On the 22nd he writes to his father: "How I envy you your mountain and lake wanderings [in Switzerland], and how much I wish I could be with you and the dear sisters amid such a beautiful country. What a relief it would be after the sea-like plain of Upper India, to say nothing of the delight of seeing you all again! ... I an not yet able to walk or ride, but I make my friends drive me in their carriages." He had "quite a host of guests" staying with him during a great race meeting at Lahore, in which Sir Walter Gilbert might be seen, at the age of sixty-five, "riding races against all comers, professional and gentlemen riders, and beating them all."

In December 1849 Lord Dalhousie paid his first visit to the capital of his new province. "Great have been the doings," writes Hodson on the 7 th"two balls, two darbârs, two levees, a féte chamipêtre, and an investiture of the Bath, all in one week. . . . I had only just strength enough to stand up during the proceedings. We civil employés gave a ball last night to Lady Dalhousie and the Governor-General. 
... But the event to me was my introduction to Sir Charles Napier, and a 'big talk' I had with him. I have been long looking forward to this, and was much pleased.... I am writing against time, as I am going to dine with Sir C. Napier en famille." 1

In the first days of 1850 Hodson was staying with the Lawrences for change of air at Lahore. "I go into camp to-morrow," he writes on the 5th, "for the same object, and hope at length to shake off the effects of my long ailings. It is three months since I mounted a horse, and that in India, and in this beautiful climate, where one ought to be in the saddle half the day. I am thoroughly weary of contemplating four white walls and a white roof. The bare barn-like rooms, without curtains, colour, or ornaments, do so weary one's eyes after a few weeks' constant confinement. Commend me to a camp life, even though you could not leave your tent without being shot at! Sir C. Napier is coming out very strong, and routing people up amazingly.... He is frightened, as he well may be, at the fearful want of discipline in the native army. . . Sir Henry talks of our making a tour together among the wilds of the Punjâb."

It was at this time that Hodson made or renewed the acquaintance with William Arnold, the youngest and not least gifted son of Rugby's famous headmaster. In the young ensign of a native infantry regiment, the future author of 'Oakfield,' Hodson found a companion suited to his own scholarly tastes, and responsive to his more thoughtful moods.

1 The hero of Miâni had just succeeled Lord Gough as commander-in-chief. 
"He is quite fresh and very Arnold-like, and does me a world of good. One feels at home again with some one to speak to about former days, and of sense sufficient for conversation. $\mathrm{He}$ is a shrewd clever lad, I think." 1

By the 21st of January Hodson had reached Pathankôt in company with Sir Henry Lawrence. He hoped to see

\section{" our coursers graze at ease}

Beyond the blue Borysthenes,"

the name by which he had dubbed the Indus before his return to civilised life. He was now able to ride again, "though not quite with the same firmness in the saddle as of yore. I have no doubt, howerer, that ere we do see the 'Borysthenes' I shall be as 'game' for a gallop of one hundred miles on end as I was last year at this season."

Some weeks later Hodson became assistant to the Deputy-Commissioner of Amritsar, Charles B. Saunders, - "a very nice sort of fellow, with an exceeding pretty and nice wife." For the Commissioner himself, Mr (afterwards Sir Robert) Montgomery, he soon conceived a strong liking. "He is a very able man, and at the head of his service in many respects." His letters of this period seem to attest the depressing influence of three months' illness, crowned by an attack of jaundice, from which he was only just recovering.

1 William Delafield Arnold soon exchanged the life of a soldier for the duties of a public teacher. He became a Director of Public Instruction in the Punjâb, and died at Gibraltar on his way home in April 1859. Readers of Matthew Arnold may remember the touching verses in which he mourned his brother's untimely death. See 'Matthew Arnold's Poetical Works,'p. 294. Macmillan, 1890. 
He looked back regretfully to the stirring life he had led on service with the Guides; and he brooded, not without cause, over the fact of his exclusion from the honours bestowed on deserving officers after the late campaign. "It is now two years," he writes on March 4, "since I was made an assistant to the Resident, and within a few months of that time I took absolute charge of a tract of country (in a state of war, too) comprising three modern districts, in one of which I am now playing third fiddle. Surely annexation was a 'heavy blow and a great discouragement' to me at least. In the military line, too, I have been equally unlucky, from the fact of my services having been with detachments instead of with the main army. I held my ground (and cleared it of the enemy, too) for weeks with only 120 men at my back, and when every officer, from General Wheeler downwards, entreated me to withdraw and give it up; I fed 5000 men and horses for six months by personal and unremitting exertion; collected the revenues of the disturbed districts, and paid $£ 15,000$ over and above into the treasury, from the proceeds of property taken from the rebels. Besides this, I worked for General Wheeler so satisfactorily that he has declared publicly that he could have done nothing without me. So much were the Sikhs enraged at my proceedings that party after party were sent to polish me off, and at one time I couldn't stir about the cointry without having bullets sent at my head from every bush and wall. However, I need not go on with the catalogue ; I have been egotistical enough as it is."

A fortnight later he inveighs with equal force and justice against the seniority system which then pre- 
vailed in India: "At the age at which officers become colonels and majors not one in fifty is able to stand the wear and tear of Indian service. They become still more worn in mind than in body. All elasticity is gone; all energy and enterprise worn out; they become, after a fortnight's campaign, a burden to themselres, an annoyance to those under them, and a terror to every one but the enemy! The officer who commanded the cavalry brigade which so disgraced the service at Chilianwâla was not able to mount a horse without the assistance of two men. A brigadier of infantry, under whom I served during the three most critical days of the late war, could not see his regiment when I led his horse by the bridle until its nose touched the bayonets; and even then he said faintly, 'Pray, which way are the men facing, Mr Hodson?' This is no exaggeration, I assure you. Can you wonder that our troops have to recover by desperate fighting, and with heary loss, the advantages thrown away by the want of heads and eyes to lead them?"

"A seniority service," he adds, "like that of the Company, is all very well for poor men; better still for fools, for they must rise equally with wise men; but for maintaining the discipline and efficiency of the army in time of peace, and hurling it on the enemy in war, there never was a system which carried so many evils on its front and face.

"I speak strongly, you will say, for I feel acutely: though I am so young a soldier, yet the whole of my brief career has been spent in camps, and a year such as the last, spent in almost constant strife, and a great part of it on detached and independent command, teaches one lessons which 
thirty years of peaceful life, of parades and cantonments, would never impart.

"There are men of iron, like Napier and Radetzky, aged men, whom nothing affects; but they are just in sufficient numbers to prove the rule by establishing exceptions. Depend upon it, that for the rough work of war, especially in India, your leaders must be young to be effective."

In a letter of April 5, Hodson tells how he had just spent three days on civil duty in Sir Charles Napier's camp. Sir Charles "was most kind and cordial; vastly amusing and interesting, and gave me eren a higher opinion of him than before. To be sure, his language and mode of expressing himself savour more of the last than of this century-of the camp than of the court; but, barring these eccentricities, he is a wonderful man; his heart is as thoroughly in his work, and he takes as high a tone in all that concerns it, as Arnold did in his-that is to say, the highest the subject is capable of. I only trust he will remain with us as long as his health lasts, and endeavour to rouse the army from the state of slack discipline into which it has fallen. On my parting with him he said, 'Now, remember, Hodson, if there is any way in which I can be of use to you, pray don't scruple to write to me.' I didn't show him his brother's (Sir W. Napier's) letter, that he might judge for himself first, and know me per se, or rather per me: I will, however, if ever I see him again."

In the same letter he refers to the death of Dr Amold as "a national misfortune. . . . As it is, the influence which he did produce has been most 
lasting and striking in its effects. It is felt even in India; I cannot say more than that.

"You should come and live in India for five years," he adds, "if you wished to feel the benefit of our 'established' forms of Christianity. Even the outward signs and tokens of its professioncathedrals, churches, colleges, tombs, hospitals, almshouses-have, I am now more than ever convinced, an influence on men's minds and principles and actions which none but those who have been removed from their influence for years can feel or appreciate thoroughly. . . A few cathedrals and venerable-looking edifices would do wonders in our colonies. Here we have nothing physical to remind us of any creed but Islamism and Hinduism. The comparative purity of the Moslem's ereed is shown admirably in the superiority in taste and form of their places of prayer. Christianity alone is thrust out of sight! A barrack-room, a ball-room, a dining-room, perhaps a court of justice, serve the purpose for which the "wisdom and piety of our ancestors' constructed such noble and stately temples; feeling, justly, that the human mind in its weakness required to be called to the exercise of devotion by the senses as well as by reason and will; that separation from the ordinary scenes of everyday life, its cares, its toils, its amusements, is necessary to train the feelings and thoughts to that state in which religious impressions are conveyed. I have not seen a church for three ycars and more, nor heard the service of the Church read, save at intervals in a room in which, perhaps, the night before, I had been crushed by a great dimner- 
party or worn out by the bustle and turmoil of suitors. The building in which one toils becomes intimately associated with the toil itself. That in which one prays should at least have some attribute to remind one of prayer. Human nature shrinks for long from the thought of being buried in any but consecrated ground; the certainty of lying dead some day or other on a field of battle, or by a roadside, has, I have remarked, the most strange effect on the soldier's mind. Depend upon it, the same feeling holds good with regard to consecrated places of worship. You may think this fanciful, but I am sure you would feel it more strongly than I do were you to live for a time in a country where everything but religion has its living and existent memorials and evidences."

Hodson had just made himself comfortable in Amritsar, in a pretty garden-house fitted up with doors and windows, when he found himself driven by the state of his health to go on four months' leave to the hills. Going away was, he felt, "a great bore in some respects, as it may be a hindrance in the way of promotion, and, moreover, I am reduced to the state of half-pay for the time I am on leave. On the other hand, neither promotion nor pay are any good so long as life is a burden to one by reason of weakness and sickness." 


\section{CHAPTER IX.}

FROM KASHMIR TO KUSSOWLIE. 1850-1851.

Early in June Hodson quitted Amritsar to join Sir Henry Lawrence on the road to Kashmir. By the 10th they had reached the summit of the first high ridge southward of the snowy range, and were only about sixty miles from the valley itself. "To me," he writes, "travelling is life, and in a country where one has no home, no local attractions, and no special sympathies, it is the greatest eomfort in the world. I get terribly ennuyé if I am in one place for three months at a time; yet I think I should be just as tame as ever in England, quite domestic again."

The travellers were resting in the Kashmir valley, the beanty of which enraptured Hodson, who had only seen it before in its winter dress. "Nothing ean exceed the luxuriant beauty of the vegetation, the plane-trees and walnuts especially, except the squalor, dirt, and poverty of the wretehed Kashmirians. The king is avaricious, and is old. The disease grows on him, and he won't look beyond his money-bags. There is a capitation tax on every individual practising any labour, trade, profession, or employment, collected daily. Faucy the 
Londoners having to go and pay a fourpenny- and a sixpenny-bit each per diem for the pleasure of living in the town. Then the tax on all shawls, goods, and fabries is about seventy-five per cent, including eustom duty, and this the one solitary staple of the valley. . . . What a garden it might be made! Not an acre to which the finest water might not be conveyed without expense worth naming, and a climate where all produce eomes to perfection, from wheat and barley to grapes and silk."

On the 20th they went northwards towards Ladâkh, whence they passed on through Iskardo, across the Indus, to Gilgit- "a terra incognita to which, I believe, only one European now living has penetrated." "Sir Henry Lawrence," he adds, "is not well, and certainly not up to this trip, but he has made up his mind to go. I do not gain strength as fast as I could wish, but I fancy, when once thoroughly unstrung, it takes a long time to recover the wonted tone."

By the end of July our traveller's were encamped at Kargil, only a few marches from Leh, the chief town in the Tibetan province of Ladâkh. "As far as the pass," he writes to Mr F. A. Foster, "dividing Kashmir from Tibet, all was lovely, rich woods and green sloping lawns, covered with a profusion of our English garden - flowers, interspersed with mighty peaks and savage rocks. You cross the ridge and all is changed-glaciers and vast masses of mountain alone meet the eye, and as you descend the valley of the Drâp river, day after day you have but a wall of mountains on your right hand and on your left, and a torrent rushing along by your side to join the Indus. . . . We are among the Bhôts here, 
Buddhists by creed, and the ugliest mortals I ever beheld. Their features are an immortal smash, scarce cognisable one from another, with low villainous-looking forehead and bad eyes. No wonder, since they live half buried in snow during six months of the year! and have to grind hard for a livelihood the remainder of it. I need hardly say that their language is unfit for ears polite, and undistinguishable from that of a calf or wild beast. Neither gods nor men could undertake such a task as deciphering it, one would think, yet I believe a romantic Pole or Russian really did make a vocabulary thereof, and I doubt not the Boden professor would lecture off-hand on the subject."

On August 4 Lawrence's camp was pitched at Kalsi in Ladâkh. "The kitchen," writes Hodson, "is under a neighbouring tree; and round a fire are squatting our gallant guards, a party of Maharaja Gulâb Singh's household brigade. Some of his people accompany us, and what with followers, a munshi or two for business and their followers, I daresay we are a party of two or three hundred souls of all colours and creeds-Christians, Mussulmans, Hindus, Buddhists, Sikhs, and varieties of each. The creeds of the party are as varied as their colours; and that's saying a good deal, when you contrast my white face and yellow hair with Sir Henry's nut-brown, the pale white parehmentycolour of the Kashmiri, the honest biunette tinge of the tall Sikh, the clear olive-brown of the Rajput, down through all shades of dinginess to the deep black of the low-caste Hindu. I am one of the whitest men in India, I fancy, as instead of burning in the sun, I get blenched like endive or celery. 
How you would stare at my long beard, moustache, and whiskers. . . The Indus is brawling along 500 feet below us, as if in a hurry to get 'out of that'; and above, one's neck aches with trying to see to the top of the vast craggy mountains which confine the stream in its rocky channel. So wild, so heavenforsaken a scene I never beheld; living nature there is none. In a week's journey I have seen three marmots, two wagtails, and three jackdaws, and we have averaged twenty miles a-day."

After some more marches of the same average length, the party arrived at Leh or Ladâkh, which Hodson describes as "a small town of not more than 400 houses, on a projecting promontory of rock stretching out into the valley formed by one of the small feeders of the Indus. For the people, they are Bhôts, and wear tails, and have flat features like the Chinese, and black garments. The women, unlike other Asiatics whom I have seen, go about the streets openly, as in civilised countries; but they are an ugly race, and withal dirty to an absolutely unparalleled extent. They wear no headdress, but plait their masses of black hair into sundry tails half-way down their backs. Covering the division of the hair from the forehead, back, and down the shoulders, is a narrow leathern strap, universally adorned with rough turquoises and bits of gold or silver:" One old Rani on whom Lawrence and Hodson called had her head adorned with a broader strap, on which were sewn 156 large turquoises reckoned to be worth several hundred pounds.

"The climate is delightful; it never rains; the sky is blue to a fault, and snow only falls sparingly 
in winter, though the climate is cold, being 10,000 feet (they say) above the sea. In boiling water the thermometer was only $188^{\circ}$. I never felt a more exhilarating air. That one week quite set me up, and I have been better ever since. The Llamas or monks, with their red cardinals' hats and crimson robes, look very imposing and monastic, quite a travesty of the regular clergy, and they blow just such trumpets as Fame does on monuments in country churches. Jolly friars they are, and fat to a man."

After a week spent at Leh they crossed the mountain ridge which separates the two branches of the Indus. Descending the northern or right stream, they reached Iskardo, the capital of Baltistan, or Little Tibet. This place Hodson characterised as "a genuine humbug. In the middle of a fine valley some 6000 feet above the sea, surrounded by sudden-rising perpendicular mountains 6000 feet higher, stands an isolated rock washed by the Indus, some two miles by three-quarters - a little Gibraltar. The valley may be ten miles by three, partially cultivated, and inhabited by some two hundred scattered houses. There's Iskardo. There was a fort on the rock, but that is gone, and all, as usual in the East, bespeaks havoc: only Nature is grand here. The people are Mussulmans and not Bhôts, and are more human-looking, but not so well clad."

Hodson was surprised to find Iskardo so much hotter than he had expected. On August 25 the

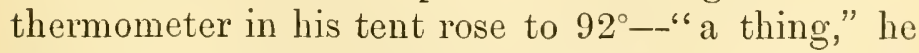
says, "for which I cannot possibly account, as there is snow now on all sides of us." 
About the middle of September Hodson parted company with Sir Henry Lawrence in Kashmir, and made his way across the Punjâb to Simla, where he purposed spending a few days with his old friend Mr James Thomason. Sir Henry and he had parted the best of friends; and Sir Henry urged him to use all the influence he could command at Simla, in order to obtain the promise of a brevet majority, whenever he might gain the rank of regimental captain, as well as the immediate reward of a local majority for his services in the late war.

What Sir Henry himself thought of his young companion appears in his letter of August 29 to his brother George: "I have had a nice tour with Hodson, who makes a good travelling companionenergetic, clever, and well-informed. I don't know why you did not take to him at Peshawar. He has his faults,-positiveness and self-will among them, -but it is useful to us to have companions who contradict and keep us mindful that we are not Solomons. I believe that if Sir Charles Napier stood on his head and cut capers with his heels, à la Boileau, he would consider it quite right that all commanders-in-chief should do so. . . . Toryism and Absolutism are right, Liberty only another name for Red Republicanism. So you see we have enough to differ upon." 1

Among other motives for Sir Henry's visit to

1 Merivale's 'Life of Sir Henry Lawrence.' The story goes that Boileau of the Bengal Engineers, while awaiting an audience of the Governor-General, amused himself by standing upon his head. In this posture he was still to be seen, dangling his legs in the air, when the great man suddenly entered the room. 
Kashmir had been the purchase of shawls and other noteworthy products of Kashmiri handlooms, which would take their place in the Indian department of the Great Exhibition, to be held in the following year in the great glass palace designed by Sir Joseph Paxton. Hodson, of course, threw himself gladly into the congenial business of selecting the daintiest samples of native workmanship. Nor could he resist the temptation to order a pair of shawls on his own account. As the making of these elaborate works of art would take many months, he trusted that he would have the means of paying for them when the bills were sent in.

In due time the precious goods were delivered, but the means of payment were not at once forthcoming. Hodson therefore sent the shawls to England for sale, and the money obtained for them enabled him at last to meet the claims of the Kashmiri merchants. Owing to some miscarriage there had been unforeseen delays in the settlement of this affair; and the merchants complained to Sir Henry Lawrence, who was naturally much annoyed, and no doubt spoke his mind freely to the seeming delinquent. It is quite a mistake, however, to suppose that Sir Henry's wrath on this occasion went beyond a passing outburst over an act of venial indiscretion due to his young friend's sanguine temperament alone. Sir Henry's whole conduct at this period belies the assertion put forward by Hodson's enemies, that he had lost all faith in Hodson's personal integrity. Sir Henry's two most intimate friends, Lord Napier of Magdala and Sir Robert Montgomery, both assured the Rev. 
George H. Hodson "that they never heard any intimation of the sort, nor did his brother-in-law, the Rev. J. Knox Marshall, with whom to the last he most constantly corresponded in England." Mr Knox Marshall well remembers "the way in which Sir Henry used to write respecting your noble and distinguished brother. Among the many whose character for honour, bravery, and courage those trying times developed, no one stood higher, few so high." 1

That Hodson's " unscrupulous character came out at every step" of the Kashmir tour must be regarded as a flight of pure fancy on the part of a writer who goes out of his way to asperse the character of a man whose worst failings sprang from no sordid or ignoble source.

In this connection I may refer again to the testimony of his old schoolfellow, Mr Thomas Arnold: "I firmly believe that the charges and imputations which have been heaped upon his memory are for the most part false. When he is accused of peculation, falsification of accounts, misappropriation of funds, \&c., I should oppose, unless evidence much more damaging than has yet been brought forward can be produced, an unhesitating negative. I do not believe that Hodson was capable of base or ignoble acts. He had an honest and upright nature." 2 That Hodson was the "soul of honour" has always been the settled conviction of that other schoolfellow, Mr F. A. Foster, with whom he corresponded nearly to the last. Such evidence to early character counts for much when

${ }^{1}$ Hodson of Hodson's Horse.

2 Passages from a Wandering Life. By Thomas Arnold. 
it is borne out by the concurrent testimony of those who knew the same man best in after-years.

"Servetur ad imum

Qualis ab incepto processerit, et sibi constet,"

is a sound working principle in life as well as art.

To return to Hodson and his Simla experiences in October 1850. In a letter of the 21st, written under Thomason's hospitable roof, he says: "The ehange to the utter comfort and civilisation of this house was something 'stunning'; and I have not yet become quite reconciled to dressing three times a-day, black hat, and patent-leather boots. I need hardly say, however, that I have very much enjoyed nry visit and my 'big talks' with Mr Thomason. $\mathrm{He}$ is very grey, and looks older than when I saw him in 1847, but otherwise he is just the same, working magnificently, and doing wonders for his province. Already the North-West Provinces are a century in advance of the Bengal Proper ones. As a governor he has not his equal ; and in honesty, high-mindedness, and indefatigable devotion to the public goor, he is facile princeps of the whole Indian service. Nor is there a household in India to match his; indeed it is about the only 'big-wig' house to which people go with pleasure rather than as a duty. I saw Sir Charles Napier, too, and dined with him last week. He is very kind and pleasant, and I an very sorry on public grounds that he is going away."

On November 4 he writes from Kussowlie: "Mr' Thomason will have told you of the power of civility I met with at Simla from the 'big-wigs,' and that even Lord Dalhousie waxed complimentary, 
and said that 'Lumsden and Hodson were about the best men he had' (that I write it that shouldn't!), and that he promised to do his best to get me a brevet majority as soon as I became in the course of time a regimental captain. And Sir Charles Napier (the best-abused man of his day) was anxious to get for me the staff appointment of brigade-major to the Punjâb Irregular Foree-i.e., of the six newly raised eavalry and infantry regiments for the frontier service. He did not suceed, for the berth had been previously filled up unknown to him; but he tried to do so, and that's a compliment from such a man. I hope I need not say that this good deed of his was as spontaneous as a mushroom's birth. . . . Sir Henry and Lady Lawrence have both repeatedly charged me with kindly greetings to you all and to the Archdeacon. I am on a more comfortable footing with Sir Henry now than ever almost, and he is, as you know, most kind when his temper is good."

About this time he was appointed to act as personal assistant to Mr G. Edmonstone, then Commissioner for the Cis-Satlaj States. In spite of this new promotion Hodson "hankered after the Guides as much as ever, and would eateh at a good opportunity of returning to them with honour." He had only turned eivilian against his own feelings, at the advice of Sir Henry and Mr Thomason. He had refused six months ago to apply for a vacaney in the corps of Guides, because he knew that Lumsden would disapprove of his passing over the heads of senior offieers. "Now," he writes, "both Sir Henry Lawrenee and Mr Thomason are very sorry that I ever left the corps, and that they advised the step. 
Things have taken a different turn since then, and it is confessedly the best thing a young soldier.can aspire to. I know that my present line is one which leads to more pecuniary advantages; but the other is the finer field, and is far more independent. I shall work away, however, cheerfully in the civil line until I see a good opening in the other, and then I fear you will hardly persuade me that sitting at a desk with the thermometer at $98^{\circ}$ is better than soldiering - i.e., than communding soldiers made and taught by yourself!"

Returning to Amritsar in the middle of November, Hodșon was "up to the neck in work" for about three weeks before joining his new chief at Lahore. Here he found his work both pleasanter and freer from routine than that which he had left behind. At Lahore he employed his leisure "in cramming Hindi for a useless examination in a tongue unknown on this side the Ganges." He was getting "tired of zeal-it is unprofitable. For the future I mean to take mine ease. I see that men who do so get on better than I do, and enjoy themselves much more! So good-bye to enthusiasm and zeal and all that sort of thing. I have hitherto worked hard, it does not pay, and I shall try what taking it coolly will do. Seven fevers, a broken constitution, a bald head, and a character for hard work are all that I have gained, and it is time to try another line." 1

His temper at this time seems to have been ruffled by the snubbings he had incurred from the authorities-" no one knows why or wherefore."

February 21, 1851, the anniversary of Gujarît,

1 Letters supplied by Miss Hodson. 
was "curiously marked," he writes, "by the announcement that the net balance of receipts over expenditure for the past year for the newly acquired provinces has reached upwards of a million sterling. Lord Dalhousie's star is in the ascendant. His financial measures are apparently all good when tried by the only standard admissible in the nineteenth century - their success."

His arrival at Kussowlie towards the end of March wonderfully refreshed him both in body and mind. "Talk of Indian luxuries! there are but two-cold water and cool air! I get on very comfortably with my new 'chief.' He is a first-rate man, and has a most uncommon appetite for work, of which there is plenty for both of us. We cover a good stretch of country-comprising five British districts and nine sovereign states; and as the whole has been in grievous disorder for many years, and a peculiarly difficult population to deal with, you may imagine that the work is not slight. . . . I was at work a whole day lately orer one case, which, after all, involved only a claim to about a quarter of an acre of land! You will give me credit for ingenuity in discovering that the result of some half-dozen quires of written evidence was to prove that neither of the contending parties had any right at all!"

Hodson had been staying for a time with Captain Douglas of the 60th Rifles. "There is not a better man or more genuine soldier going. This may appear faint praise, but rightly understood, and conscientiously and boldly worked out, I doubt whether any other profession calls forth the higher qualities of our nature more strongly than does that 
of a soldier in times of war and tumults. Certain it is that it requires the highest order of man to be a good general, and in the lower ranks (in this country especially), even with all the frightful drawbacks and evils, I doubt whether the Saxon race is ever so pre-eminent, or its good points so strongly developed, as in the 'European' soldier serving in India, or on service anywhere."

His word-picture of the view which his own house commanded from the top of a ridge some 8000 feet above sea-level deserves quoting here: "In the immediate foreground rises a round-backed ridge, on which stands the former work of my hands, the 'Lawrence Asylum'; while to the westward, and down, down far off in the interminable south, the wide glistening plains of the Punjî̀b, streaked with the faint ribbon-like lines of the Satlaj and its tributaries, and the wider sea-like expanse of Hindustan, stretch away in unbroken evenness beyond the limits of vision, and almost beyond those of faith and imagination. On the other side you look over a mass of mountains up to the topmost peak of Himalaya. So narrow is the ridge that it seems as though you could toss a pebble from one window into the Satlaj, and from the other into the valley below Simla."

After seven or eight hours' work he spent the rest of his day in the society of the 60th Rifles"the very nicest and most gentlemanly regiment I ever met with."

In May Hodson's spirits were greatly raised not only by the receipt of letters from home, but also by his advancement to the higher grade of assistants to Commissioners in the Punjâb. Of the letters 
from home he writes: "It is very pleasant to receive these warm greetings, and it refreshes me when bothered or overworked, or feverish, or disgusted. I look forward to a visit to England and home with a pleasure which nothing but six years of exile can give."

With regard to his new official rank, it appears that Lord Dalhousie had yielded at last to the friendly pressure exerted by Hodson's superiors, especially by Mr Edmonstone, who had "commenced attacking him in my favour before I had been under him four months."

To the Rev. E. Harland he writes on June 11 : "The old visions of boyhood have given place to the vehement aspirations of a military eareer and the interests of a larger ambition. I thirst now not for the calm pleasures of a country life, the charms of society, or a career of ease and comfort, but for the maddening excitement of war, the keen contest of wits involved in dealing with wilder men, and the exercise of power over the many by force of the will of the individual. Nor am I, I hope, insensible to the rast field for good and for usefulness which these vast provinces offer to our energies, and to the high importance of the trust committed to our charge."

In October of the same year he writes to his father: "By the end of next summer I hope to be as strong as I ever hope to be again. That I shall ever again be able to row from Cambridge to Ely in two hours and ten minutes, to run a mile in five minutes, or to walk from Skye (or Kyle Hatren Ferry) to Inverness in thirty hours, is not to be expected, or perhaps desired. But I have every 
hope that in the event of another war I may be able to endure fatigue and exposure as freely as in 1848. . . . I have no doubt that matrimony will do me a power of good, and that I shall be not only better, but happier, and more careless than hitherto."

Hodson had just been deeply grieved by the death of Colonel Bradshaw, who had commanded the 60th Rifles in the second Sikh war. "He was the beau idéal of an English soldier and gentleman, and would have earned himself a name as a general had he been spared. A finer and nobler spirit there was not in the army. I feel it as a deep personal loss, for he won my esteem and regard in no common degree." 


\section{CHAPTER X.}

MARRIAGE AND PROMOTION TO THE COMMAND OF THE GUIDES. 1852-1854.

Towards the close of 1851 Hodson went down to Calcutta eager to meet and welcome his future wife. During his stay in the city of palaces he made the acquaintance and won the friendship of the late Mr Frederick Lushington, then holding a prominent post in the Civil Service of Lower Bengal. A subsequent letter to Miss Hodson gires Mr Lushington's impressions of his new friend's character and appearance :-

"His height struck me as about 5 feet 11 inches, remarkably well made, lithe, and agile; his hair had slightly receded from a high and most intellectual forehead, and was light brown and curly; his eyes were blue, but, far from being soft and gentle, were animated by a peculiarly determined and sometimes even fieree look, which might occasionally change to one of mischievous merriment, for he was keenly susceptible of 'the ridiculous' in whatever shape it manifested itself, but usually his look impressed one at once with that idea of his determination and firmness which have ever characterised his actions; his nose was inclining to the aquiline, and the 
curved thin nostrils added a look of defiance in no ways counteracted by the compressed lips, which seemed to denote many an inward struggle between duty and inclination.

"These are my impressions of your brother as I last saw him, and if you add to this an open frank manner that, bon gré mal grée, impressed you favourably at first sight with the owner, you will have the charming ensemble that presides over my recollections of three as happy weeks as I ever passed." ${ }^{1}$

On the 5th of January 1852 Lieutenant William Hodson was married at the cathedral in Calcutta to Susan, daughter of Captain C. Henry, R.N., and widow of John Mitford, Esq. of Exbury, Hants. They had met for the first time in Guernsey. "She is wonderfully little altered," writes Hodson, "since I saw her in 1844, and being in better health, she looks younger. Sir Lawrence Peel has placed a house at our disposal here, and we are very comfortable indeed and supremely happy."

"In the cold weather of 1851-52," writes Mr Seton-Karr, "I was surprised one morning to receive a letter from Hodson saying that he was on his way to Calcutta to receive Mrs Mitford, the lady whom he was engaged to marry. I was then Under Secretary in Lord Dalhousie's Government, and received Hodson in my house in Camac Street. He brought with him as attendant a faithful Afghan, who, he assured me, had been with Eldred Pottinger and had seen thousands of Persians and, as he averred, Russians to boot, hurled back from the walls of Herat in 1838.

"Hodson's marriage was quite private. No one 1 MS. letter to Miss Hodsor. 
was present except myself, the late Sir Frederick Currie, then a member of the Supreme Council, and Sir Lawrence Peel, the Chief-Justice of the Supreme Court of Calcutta. Hodson then returned to his duty in the Punjâb, and we never met again."

Hodson himself was glad to get away as soon as possible from the capital of Bengal. "I hate Calcutta with no common dislike, and hope this will be my last visit to the city of palaces and uncovered crains."

After a short but pleasant visit to Mr Thomason at Agra-"we have nothing which kindness could suggest left undone for us "- the newly-wedded pair reached Umballa in the first week of March 1852. Here the call of duty compelled Hodson to separate from his wife, whom he left for the time in the charge of Colonel and Mrs Trevor Wheler. He himself had to make the best of his way to Ludhiâna in order to "try a lot of gentlemen who have devoted their youthful energies to strangling their neighbours by the simple art of Thuggi."

Early in April he appears to have joined the camp of Sir William Gomm, the new commander-in-chief at Patiâla. On the 13 th he writes to his wife that he had been nearly worked off his feet. The commander-in-chief was to start at 10 A.M. for the hills, while he himself intended to ride on and breakfast with $\mathrm{Mr}$ Lewin Bowring at Umballa on his way back to Kussowlie.

On the breaking ont of war with Burmah he prepared to rejoin his regiment, the 1st Bengal Fusiliers, which had been despatched down the Ganges to Calcutta in order to take part in the war. But the 1 Letters supplied by Miss Hodson. 
Governor-General saw no reason for allowing officers on civil employ to rejoin their regiments in the usual manner, and Hodson was "thus spared what would have been a very fatiguing and expensive trip, with very little hope of seeing any fighting." It was not long, however, before his soldierly instincts and aspirations were to be gratified by his appointment to the post he coveted beyond all others. On September 23 he writes from Kussowlie:-

"Lumsden, my old commandant in the Guides, goes to England next month, and the GovernorGeneral has given me the command which I have coreted so long. It is immense good fortune in every way, both as regards income and distinction. It is accounted the most honourable and arduous command on the frontier, and fills the public eye, as the papers say, more than any other,

"This at the end of seven years' service is a great thing, especially on such a frontier as Peshâwar, at the mouth of the Khaiber Pass. You will agree with me in rejoicing at the opportunities for distinction thus offered to me."

Mr Thomason congratulated Hodson most sincerely on the new career thus opened before him. "I have never ceased to reproach myself for advising you to leave the corps, but now that you have the command, you will be all the better for the dose of civilianism that has been intermediately administered to you."

Neanwhile he had taken his wife up to Simla for change of air and medical advice. "She is now quite well," he writes, "and rejoices in the prospect of Peshâwar almost as much as I do. . . There is a beautiful hill station near Rawal Pindi, where she 
can go and take refuge whenever the weather is hot at Peshâwar. On October 7 he writes from K.ussowlie to congratulate his old friend the Rev. F. A, Foster on his promotion to the living of Saxby.

"I know the neighbourhood, my father's brother, who lives at Goole on the Humber, having introduced me in 1833 to the banks of that muddiest of rivers and its Danish associations. Curiously enough, your letter reached me just as I also had attained the great object of my ambition in India, the command of the corps of Guides. The Governor-General gave me this distinguished command in the most flattering manner, in acknowledgment of services during the last war in the Punjâb, although I am unprecedentedly young (in the service!!) for such a command. I obtain the command of 900 men (a battalion of infantry and a squadron and a half of cavalry) with four European officers. To make it a more decided compliment, one of the officers is my senior in the army! and men twice and three times my standing were desirous of the post.

"My good wife," he adds, "and I have been separated for some time, with only an occasional 'lucid interval' for a day or two. I am tied to this hill by my official duties, but it disagreed so much with her that I was obliged to send her to Simlathirty-five miles off. She is now quite well-thank God for her - and rides her fifteen miles before breakfast without fatigue! We hope to set out for Peshâwar (500 miles off, and neither roads nor railroads!!) in a few days."

The military secretary to the Punjâb Board had just been offering to exchange appointments with 
him; but "though I should gain, and he would lose $£ 200$ a-year, by the 'swop,' I would not listen to him. I prefer the saddle to the desk, the frontier to a respectable, wheel-going, dinnergiving, dressy life at the capital; and ambition to money!'

On the eve of his departure for Peshâwar he received a farewell note from $\mathrm{Mr}$ Edmonstone, who would not have him go away without thanking him heartily for the support and assistance he had always given him "in all matters, whether big or little, since you joined me, now twenty months and more ago. I have in my civil and criminal reports for the past year recorded my sense of your services and your official merits; but our connection has been peculiar, and your position has been one which few would have filled either so efficiently or so agreeably to all parties. You have afforded me the greatest aid in the most irksome part of my duty, and have always with the utmost readiness undertaken anything, no matter what, that I asked you to dispose of, and I owe you more on this account than a mere official acknowledgment can repay adequately."

Writing from Peshâwar on October 31 to the wife whom he had left at Simla, he describes the station there as " a beautiful place, and when more houses are built it will be the best station in India."

"My good friend Lumsden," he writes a week later, "has exceeded all I expected in the way he. has left affairs, and I have no slight work in organising and arranging the economical details of the regiment: fortunately Turner is a good 
hand at business and accounts, and we shall get all things straight, no doubt, in time." On November 8, the day on which Mrs Hodson was to begin her journey from Simla to Jalandhar, her husband was encamped at Haripur, among the mountains of Hazâra, in company with his friend Colonel Mackeson, then Commissioner of Peshâwar. From Pakli on November 14 he writes, "We are lying peacefully here, and not a shot will be fired in this direction."

He had marched off, in fact, at the head of his Guides to establish peace and order among the wild tribes of Hazâra, who only three years before had yielded to the kindly rule of Major James Abbott. The country through which he was marching extends north-eastward of Attock along the left bank of the Indus. "We are now (December 16) in an elevated valley, surrounded by snowy mountains, and mighty cold it is, too, at night. We have come about 125 miles from Peshâwar, and having marched up the hill, are patiently expecting the order to march down again." In his opinion "the storm Colonel Mackeson brewed seems most absurd, and I hope it will soon be over."

In a previous letter from Pakli he had written: "It is utterly useless for us to be here now. I left camp before daylight yesterday, and did not get back to breakfast till 5 p.M. There had been a fight between the natives, and I was sent to see what had happened." In his account of what had happened he spoke of the natives stringing the ears of their victims to show how many they had killed. On the 14th he had written to Mrs Hodson: "You will be at Lahore to-day, and I shall hear of your 
impressions of my good friend indeed, Sir $\mathrm{H}$. Lawrence, and his Irish lady. I am charmed by the arrival in camp of my good friend Colonel Napier, whom you would like, I am sure. He is to me a most lovable person." Three days later he writes to her again from Pakli, "At last the force has moved off this hateful spot, and moved on towards the enemy, and I have remained behind to assist Colonel Napier in surveying the country."

On the 24th he begs his wife to assure Sir Henry that he is "deeply grateful to him for all he has done for me. I hear he thinks I am not so. I am glad you like Neville Chamberlain; he is an admirable man in all ways. I often wish I was more like him."

The campaign, however, was not to end quite so peacefully as Hodson had expected. On January 3, 1853 , he tells his wife that "the last few days have been an incessant exertion and fatigue, and nothing but unwearying toil and great care and skill saved us from great loss, and we have rejoined the camp after this most successful expedition, as it has proved." Next day he writes again: "I may say you have no reason to be ashamed of your soldier husband. It was the most difficult and arduous affair I was ever engaged in, and Colonel Napier's ready attention to any suggestion of mine was very gratifying to me."

The enemy, in fact, had not given way without some hard fighting. One engagement, which lasted from sunrise to sunset, gave Hodson a fine opportunity of showing with what skill and coolness he could handle his Guides in mountain warfare under 
the most trying conditions. In speaking afterwards of this campaign, Lord Napier declared to the Rev. G. H. Hodson, "Your brother's unfailing fun and spirits, which seemed only raised by what we had to go through, kept us all alive and merry, so that we looked back upon it afterwards as a party of pleasure, and thought we had never enjoyed anything more."

"It was a good thing," writes Hodson on March 13 from Peshâwar, "that I had the opportunity of leading the regiment into action so soon after getting the command, and that the brunt of the whole should have fallen upon us, as it placed the older men and myself once more on our old footing of confidence in one another, and introduced me to the younger hands as their leader when they needed one. . . . I need therefore only add that it was the hardest piece of service, while it lasted, I have seen with the Guides, both as regards the actual fighting, the difficulties of the ground (a rugged mountain 7000 feet high and densely wooded), and the exposure."

In the previous November Hodson and Lumsden had exchanged warm farewell greetings at Peshâwar. Late in the following January Lumsden began his voyage homeward from that eity of palaces, which he loved as little as did his former subaltern. On January 23 Lumsden writes to Hodson from aboard the ship Monarch: "Yesterday I had two whole hours with the Governor-General, who is delighted with the work you have been doing in Hazâra, and I congratulate you most sincerely in your commencement as a commandant of Guides. There is no doubt in my mind, from what the Lord said, 
but that you will very soon have a considerable increase to the dear old regiment, which I am sure will delight you all. Don't say a word about this till the order is out, as it would rile the little Lord considerably to hear that the report had got abroad. I write to you, as you may like to think over what lads to promote and in what particular description of men you would make the additions. You will probably get your cavalry made up to 400 sabres and the infantry to 600 or 800 rifles. This, of course, is my own speculation, but the increase you may look on as puckct.

Hodson's regiment during the campaign consisted of five English officers, including the surgeon, Dr Lyell: "Then I have 300 horse, including native officers, and 550 foot, or 850 men in all, divided into three troops and six companies, the latter armed as riflemen." In order to prevent the danger of secret combinations no two troops or companies contained men of the same race. One company, for instance, was composed of Sikhs, another of Afridis. Pathans, Gurkhas, and Punjâbi Mussulmans, each formed a separate troop or company; in each case, also, the native officers were of a different race from the men.

About this time Horlson had been asked to take civil charge of the wild district of Yuzafzai, on the northern frontier of the Peshâwar valley, which would form the usual headquarters of the Guides. This charge he refused to undertake unless he could have the entire control in all departments of civil work. This he presently obtained, as appears from his letter of June 4: "We are encamped [near Peshâwar] on a lovely spot, on the banks of the 
swift and bright river, at the foot of the hills, on the watch for incursions or forays, and to guard the richly cultivated plain of the Peshâwar valley from depredations from the hills. We are ready, of course, to boot and saddle at all hours; our rifles and carbines are loaded, and our swords keen and bright; and woe to the luckless chief who, trusting to his horses, descends upon the plain too near our pickets! Meanwhile I am civil as well as military chief, and the natural taste of the Yuzafzai Pathans for broken heads, murder, and violence, as well as their litigiousness about their lands, keeps me very hard at work from day to day."

It occurs to him that such a life might be better suited to a careless bachelor than to "a husband with such a wife as mine," Mrs Hodson having been ordered to the hills at the beginning of May, and it might be six months before they met again.

In the same letter he describes his manner of life : "A daybreak parade or inspection, a gallop across the plain to some outpost, a plunge in the river, and then an early breakfast, occupy your time until 9 A.M. Then come a couple of corpses, whose owners (late) had their heads broken overnight, and consequent investigations and examinations; next a batch of villagers to say their crops are destroyed by a storm, and no rents forthcoming. Then a scream of woe from a plundered farm on the frontier, and next a grain-clealer to say his camels have been carried off to the hills. Is not this a dainty dish to set before-your brother? Then each of my 900 men considers me bound to listen to any amount of stories he may please to invent or remember of his own private griefs and troubles; 
and last, not least, there are four young gentlemen who have each his fancy, and who often give more trouble in transacting business than assistance in doing it. However, I have no right to complain, for I am about-yes, quite-the most fortunate man in the service; and have I not the right to call myself the happiest also, with such a wife and such a home?"

In February of this year, 1853, Sir Henry Lawrence quitted the Punjâb for ever, to the grief of all who had served under him. The time had come, in Dalhousie's opinion, for remodelling the government of his new provinces and placing a single man at its head. Sir Henry, therefore, took up the duties of agent to the Goveruor-General in Rajputâna, while his younger brother John became Chief Commissioner for the Punjâb. Sir Henry, however, amidst his own personal grievances, did not forget the friends he had left behind him. On the 13th of July he wrote :-

"I hope Mrs Hodson and yourself are alive. Pray inform me of the fact and of your whereabouts, \&c., \&c.

"By last mail I wrote to Lord Hardinge" and asked him to get you brevet rank. You had better write to Sir C. Napier (but don't use my

${ }^{1}$ In the letter to Lord Hardinge Sir Henry said: "The Guide Corps you raised at my request has held its ground as the best irregular corps in India. The present commander is a young fellow, Hodson by name, whom you gave me at Lahore in 1847. He is a first-rate soldier, and as your lordship likes young officers in command, I beg to bring him to your notice for a brevet majority. Sir C. Napier thinks highly of him, and, I believe, held out to him hopes of the rank. Hodson is a most ambitious and most gallant fellow, and very able in all departments."-Merivale's 'Life of Sir Henry Lawrence.' 
name, or it might do you harm) and say that if he moves in your favour, you think Lord Hardinge will agree. If you could get local rank till you are a captain it would be a great matter. Say nothing to any one on the matter."

Mrs Hodson had gone to the hill station of Marri, about 140 miles from Peshâwar. Here in the middle of September Hodson was " enjoying a little holiday from arms and kutchery up in the cool with Susie." In the same letter he declares that the whole upper part of the Punjâb is mountainous. "If you draw a line from Peshâwar, through Rawal Pindi, to Simla or Sabâthu, or any place marked on the maps thereabouts, you may assume that all to the north of that line is mountain country. . . . The Peshâwar valley is a wide open plain lying on the banks of the Kabul river, about sixty miles long by forty broad, encircled by mountains, some of them covered with snow for eight or nine months of the year. Yuzafzai is the north-eastern portion of this valley, embraced between the Kabul river and the Indus. Half of Yuzafzai (the 'abode of the children of Joseph ') is mountain, but we only hold the level or plain part of it. Nevertheless, a large part of my little province is very hilly. In the north-east corner of Yuzafzai, hanging over the Indus, is a vast lump of a hill called 'Mahabun' (or the 'great forest'), thickly peopled on its slopes, and giving shelter to some 12,000 armed men, the bitterest bigots which even Islam can produce. The hill is about 7800 feet above the level of the sea. This has been identified by the wise men with the Aornos of Arrian, and Alexander is supposed to have crossed the Indus at its foot. . . . 
"Poor Colonel Mackeson, the Commissioner at Peshâwar (the chief civil and political officer for the fronticr), was stabbed a few days ago by a fanatic while sitting in his verandah reading. The fellow was from Swât, and said he had heard that we were going to invade his country, and that he would try to stop it, and go to heaven as a martyr for the faith. Poor Mackeson is still alive, but in a very precarious state, I fear."

Mackeson lingered only a few days. The death of such a man, said Lord Dalhousic, "would have dimmed a victory." In the summer of 1850 he had succeeded George Lawrence as Commissioner of Peshâwar. The blow which prematurely closed his career opened to his successor, Herbert Edwardes, the road to achievements yet more splendid than any which had marked his brilliant past.

In the same month of September Hodson was saddened by the death of his friend James Thomason, in his fiftieth year, at the moment when one of the highest prizes open to a Company's servant, the governorship of Madras, had come within his grasp. "His death," wrote Hodson on October 15, "is an irreparable loss to his family and friends, but it will be even more felt in his public capacity. He had not been ill, but died from sheer debility and exhaustion produced by overwork and application in the trying season just over. Had he gone to the hills all would have been right. I cannot but think that he sacrificed himself as an example to others. You may imagine how much I have felt the loss of my earliest and best friend in India, to whom I was accustomed to detail all my proceedings, and whom I was wont to consult in every difficulty and doubt." 
Of Thomason's public eareer every one may allow, with Lord Dalhousie, that if even he "liad left no other memorial of his public life behind him, his system of general vernacular education, which is all his own, would have sufficed to build up for him a noble and abiding monument of his earthly career."

Not long after Hodson's return to his Guides he heard that his wife was about to become a mother. Riding hard all night from Peshâwar to Rawal Pindi, he was just in time to greet the arrival of the little stranger, and to see that all was well with Mrs Hodson before returning to his post near Peshâwar.

Before the end of November Hodson was once more leading his Guides in a short but brilliant campaign in the hills between Peshâwar and Kohât. The Bori Afridis were threatening to block the passes that lay between the two stations, and it became necessary to teach these persistent raiders that we could beat them on their own ground. On the moruing of November 29 a select force of Europeans, Guides, and Gurkhas, was led out by Brigadier Boileau from camp at Adizai to dislodge the enemy from the heights which formed their outer line of defence. ${ }^{1}$ Thanks to the quick turning movement carried out by Hodson's infantry, this preliminary task was soon accomplished. From the valley beyond rose a steep wall of rocks and crags, at the foot of which were three Bori villages.

Up these forbidding crags swarmed Hodson's dashing Guides and 'Turner's sturdy little Gurkhas,

1 The force comprised a mountain train, 400 of her Majesty's 22 nd Foot, 200 of the 20th Native Infantry, 400 of the 66th Gurkha Regiment, and 450 of the Guides. 
driving the enemy from rock to rock, and finally holding them at bay for several hours, while the regular troops were employed in sacking and burning the villages below. This work over, the whole force about 3 P.M. began falling back to its former halting-ground. To retire in the face of a foe now numbering more than 2000 was a task hardly less diffieult than the previous advance. "The withdrawal of the Guides and Gurkhas," says an admiring eyewitness, "was most exciting, and none but the best officers and the best men could have achieved this duty with sueh eomplete suecess. Lieutenant Hodson's taeties were of the most brilliant description, and the whole force, having been once more reunited in the plain, marehed out of the valley by the Torana Pass, which, though farthest from the British camp, was the shortest to the outer plains." ${ }^{1}$ Here they were joined by the Chief Commissioner, Sir John Lawrenee, who had watehed the whole affair from a neighbouring height.

He, too, had nothing but praise for the victors. "We had a splendid little foree," he writes to Lord Dalhousie. "The Afridis fought desperately, and the mode in which the Guides and Gurkhas erowned the heights which eommanded the villages was the admiration of every officer present. These are, indeed, the right sort of fellows. Our loss is eight men killed and twenty-four wounded. The men got no water and suffered a good deal. I think this expedition is calculated to do mueh good. The Bori valley has not been entered by an enemy for many hundred years, I believe, and the prestige which will

1 From the 'Lahore Chronicle' for December 3, 1853. 
attend the affair will be proportioned to the success of the operation." 1

How largely this success was owing to Hodson's leadership may be seen from Colonel Boileau's official despatch: "To the admirable conduct of Lieutenant Hodson in reconnoitring, in the skilful disposition of his men, and the daring gallantry with which he led his fine corps in every advance, most of our success is due; for the safety of the whole force while in the valley of the Tillah depended on his holding his position, and I had justly every confidence in his vigilance and valour."

This praise was duly indorsed by Sir William Gomm, who begged the brigadier to express to Lieutenant Hodson "my particular thanks for the great service he rendered the force under your command, by his ever-gallant conduct, which has fully sustained the reputation he has so justly acquired for courage, coolness, and determination."

Before Christmas Hodson and his wife were again together in camp at Mardân, thirty-three miles north-east of Peshâwar, where Hodson among his other duties was engaged in building a fortified cantonment for the officers and men of the Guide Corps.

"I wish you could see your little granddaughter," he writes to his father on January 2, 1854, "being nursed by a rough-looking Afghan soldier or bearded Sikh, and beginning life so early as a dweller in tents. She was christened by Mr Clarke, one of the Church missionaries who happened to be in Peshâwar. ... My second in command, Lieutenant Godby, was stabbed in the back by a fanatic the other day

1 Bosworth Smith's 'Life of Lord Lawrence.' 
while on parade, and has had a wonderful escape for his life.

"You would so delight in your little granddaughter. She is a lovely good little darling; as happy as possible, and wonderfully quick and intelligent for her months. I would give worlds to be able to run home and see you, and show you my child; but I fear much that, unless I find a "nugget,' it is vain to hope for so much pleasure just now. Meantime I have every blessing a man can hope for, and not the least is that of your fond and muchprized affection."

Writing to his wife a few days afterwards, he reported Godby as out of danger, and himself as having "been all day busy inquiring into the perpetrators and abettors of the deed, and have decided on seizing one of the principal chiefs of Yuzafzai and sending him into Peshâwar. The murderer was a servant of this Khader Khan, and certainly did not come of his own idea. I shall have plenty of circumstantial evidence at least against him."

On May 1 he tells his father that little Olivia had just recovered from a severe attack of fever. "You would so delight in her little baby tricks and ways... We look forward with intense interest to her beginning to talk and crawl about. Both she and her dear mother will have to leave for the hills very soon, I am sorry to say. We try to put off the evil day, but I dare not expose either of my treasures to the heat of Yuzafzai or Peshâwar for the next three months. . . . The young lady already begins to show a singularity of taste-refusing to go to the arms of any native 
woman, and decidedly preferring the male population, some of whom are distinguished by her special favour. Her own orderly-save the mark!-never tires of looking at her 'beautiful white fingers,' nor she of twisting them into his black beardan insult to an Oriental, which he bears with an equanimity equal to his fondness for her. The cunning fellows have begun to make use of her too, and when they want anything, ask the favour in the name of Lilli Bâbâ (they cannot manage 'Olivia' at all). They know the spell is potent."

After a five-o'clock cup of tea Hodson and his wife were wont to go out riding together for a couple of hour's. "You can understand," Mrs Hodson writes on April 15, "something of the delight of galloping over the almost boundless plain in the cool fresh air (for the mornings and evenings are still lovely), with the ground now enamelled with sweet-scented flowers, and the magnificent mountains nearest us assuming every possible hue which light and shadow can bestow. On our return to camp W. hears more reports till dinner, which is sometimes shared by the other officers or chance guests. When we are alone, as soon as dinner is over, the letters which have arrived in the evening are examined, classified, and descanted on, sometimes answered; and I receive my instructions for next day's work in copying papers, answering letters, \&c."

After a lively description of her husband's labours as a hard-worked overseer in the building of his fort, Mrs Hodson goes on to say:-

"By way of variety we have native sports on great holidays - such as throwing the spear at a 
mark, or nazabaze, which is, fixing a stake of twelve or eighteen inches into the ground, which must be taken up on the spear's point while passing it at full gallop, or putting an orange on the top of a bamboo a yard high, and cutting it through with a sword at full speed. W. is very clever at this, rarely failing, but the spears are too long for any but a lithe native to wield without risking a broken arm. The scene is most picturesque: the flying horsemen in their flowing many-coloured garments, and the grouping of the lookers-on, make me more than ever regret not having ready pencil-power to put them on paper.

"The weather has been particularly unfavourable to the progress of the fort, so that we are still in our temporary hut and tents. Of course we feel the heat much more so domiciled. W. is grievously overworked; still his health is wonderfully good, and his spirits as wild as if he were a boy again. $\mathrm{He}$ is never so well pleased as when he has the baby in his arms."

This sweet companionship lasted on till the first days of June, when mother and child were packed off on the inevitable summer visit to the Marri Hills. "It is a sad necessity," writes the husband, " and the curse of Indian life, this repeatedly recurring separation; but anything is better than to see the dear ones suffer. I am fortunately very well, and as yet untouched by the unusual virulence with which the hot weather has commenced this year."

He hoped to rejoin his wife and child in September, and accompany them back to their new home"for by that time I trust that my fortified cantonment will be ready, and our house too." 
But the happy prospect was soon to be fatally overcast. On June 26 Hodson was summoned from Mardan by tidings of the dangerous illness of his little daughter. He found her in a sinking state, but the little flame of her life still flickered on for a fortnight longer. On the morning of July 10 "she breathed her soul away, so gently that those watching her intently were conscious of no change. The deep agony of this bereavement I have no words to describe. We had watched her growth, and prided ourselves on her development with such absorbing interest and joy; and she had so won our hearts by her extreme sweetness and most unusual intelligence, that she had become the very centre and light of our home life, and in losing her we seem to have lost everything."

About ten days later Hodson was hurrying back alone to Mardan, while his wife remained at Marri until October; for he dared not take her back with him at such a season, in her then state of health. "It is very sad work to part again under these circumstances, but in this wretched country there is no help for us."

"I am alone now," he writes on September 17, "having none of my officers here save the doctor. But the border is quiet, and except a great deal of crime and villainy, I have not any great difficulties to contend with. My new fort to hold the regiment and protect the frontier is nearly finished, and my new house therein will be habitable before my wife comes down from Marri. So after two years and a quarter of camp and hutting, I shall enjoy the luxury of a room and the dignity of a house."

Before the end of October Hodson and his wife 
had entered into possession of their new home within the fort which Hodson had worked so hard to get completed. "We have, for India," he writes on October 31 , "a very pretty view of the hills and plains around us. Above all, the place seems a very healthy one. To your eye, fresh from England, it would appear desolate from its solitude, and oppressive from the vastness of the scale of scene. A wide plain, without a break or a tree, thirty miles long by fifteen to twenty miles wide, forms our immediate foreground on one side, and an endless mass of mountains on the other."

They had just heard by telegraph of Lord Raglan's victory over the Russians at the Alma. "We are in an age of wonders. Ten months ago there was not a telegraph in Hindustan, yet the news which reached Bombay on the 27th of this month was printed at Lahore, 1200 miles from the coast, that same afternoon."

Two of Lord Dalhousie's greatest services to India were a cheap uniform postage and an efficient telegraph system. The latter, in his own words, "may challenge comparison with any public enterprise which has been carried into execution in recent times among the nations of Europe, or in America itself."

On November 16 Hodson reports the commencement of negotiations between the Indian Government and the Amir of Kâbul, whom we had let severely alone ever since the failure of his last attempt to regain possession of Peshâwar. Hodson looked askance at the new policy which Colonel Herbert Edwardes had been among the first to promote. "One thing," he writes, "is certain, that 
the commencement of negotiations with us is the beginning of evil days for Afghanistan. In India we must either keep altogether aloof or absorb. All our history shows that sooner or later connection with us is political death. The sunshine is not more fatal to a dew-drop than our friendship or alliance to an Asiatic kingdom."

Hodson's views on this matter were shared by such men as John Lawrence, Abbott, Nicholson, and Outram. In spite, however, of many grave objections to any alliance with a native Power, it was fortunate for India that the policy proposed by Edwardes received the sanction of the GovernorGeneral. On March 20, 1855, was signed at the mouth of the Khaiber Pass, by John Lawrence and a son of Dost Muhammad Khan, the treaty by which the Amir of Kâbul agreed to become "the friend of our friends and the enemy of our enemies,"-the treaty which left the door open for a closer alliance whenever circumstances might seem to call for it. 


\section{CHAPTER XI.}

\section{UNDER A CLOUD. 1854-1856.}

As early as March 1853 John Lawrence, the new Chief Commissioner for the Punjâb, had written to Mr Courtenay, Lord Dalhousie's private secretary: "Hodson is, I believe, very unpopular, both in the Guides and with military men generally. I don't know exactly why this is. It cannot be that he has got promotion too early, for, though a young soldier, he is almost a middle-aged man. $\mathrm{He}$ is an ofticer of first-rate ability, and has received an excellent education. He is gallant, zealous, and intelligent, and yet few men like him. It is the case of the famous Dr Fell, whom the young lady did not like, but could not tell why she did not do so."

The process of giving a dog a bad name seems in Hodson's case to have begun within a very few months after his appointment to the command of the Guides. It is easy enough to call a man unpopular, but the question remains, how and whence the umpopularity may have arisen. A just judge, an able magistrate, or an active police officer is not likely to be much of a favourite with the criminal classes; nor will he always endear himself 
greatly even with people of his own class and calling. Hitherto, at any rate, Hodson appears to have been far from unpopular with those who knew him, whether personally or by common repute. In the 'Calcutta Review' for October 1852 Sir Richard Temple had said that "Lieutenant Hodson, marvellously attaching the Guides to himself by the ties of mutual honour, mutual daring, and mutual devotion, has on every opportunity proved that the discipline of a public school and subsequent university training are no disqualification for hazardous warfare, or for the difficult task of keeping wild tribes in check." The enthusiastic greeting which Hodson was afterwards to receive at Delhi from the men he had once commanded bore ample witness to the warmth of their affection for their former leader.

It is certain, however, that his promotion to a command so widely coveted by men of higher standing gave sore offence not only to one or two officers in the Guides, but to several others who decmed their own claims stronger than his. So bitter was the enmity displayed towards him by his adjutant, Lieutenant Turner, that in April 1854 that officer, greatly to Hodson's relief, was transferred to a regiment of Punjâb cavalry. But the stories he had meanwhile set on foot to Hodson's prejudice must have found their way to the Chief Commissioner many months before. In August 1853 John Lawrence writes to Hodson with regard to the general feeling of the Guides: "You must not be hurt at what I say, for I do it simply and solely for your own good. You may depend on it that neither the European nor the native officers 
are as razi (contented) as they might be. I have heard it from half-a-dozen clifferent quarters. At Lahore I have heard it talked of by several parties. I have heard it direct from Peshâwar, and direct from Calcutta. There may have been faults on their part, and the discipline may not have been altogether what it ought to have been. But sudden changes are best avoided. . . . If right men go wrong, people will blame you. I don't think that Pathans can bear a very strict system of drill and setting up at any time. For all these reasons, therefore, I would introduce my reforms very slowly and carefully, carrying them out in a way as little rexatious as possible." 1

In seeking to enforce his own views of military discipline, and to make his regiment as fit as possible for the work required of it, Hodson may have mored too fast in a manner too ruthless to please some of his official superiors. In the letter from which I have just quoted John Lawrence takes him to task for his rough treatment of one of his native officers: "I heard that you addressed Fathi Khan as Fathi Khan Mazîl (turned out); this was sufficient to set such a chap all of a blaze." This Fathi Khan may have been a daring soldier; Hodson looked upon him as one of those black sheep with whose services he would do well to dispense. Lawrence himself had described him to Lord Dalhousie as "a perfect devil when his blood is up, and this is very often. At such a moment he would murder his nearest and dearest relative or friend." Even Lumsden, for all his kindly tact and easy-going ways, had sometimes found that retired

1 Quoted by Bosworth Smith. 
freebooter very hard to manage. Under Hodson's more masterful rule it was not long before Fathi Khan and several other of the native officers were weeded out of the Guides in order that their places might be filled by trustier men.

He appears also to have annoyed his English subalterns in various ways, especially by getting rid of many Pathans and Afridis on whose merits they had pinned their faith. Stories to his diseredit found their way to the Chief Commissioner, who had never looked with favour on his appointment to the Guides. In May 1854 he writes to his brother, Sir Henry Lawrence, "I am in great tribulation about Hodson of the Guides. I don't know what to make of him. His courage and ability are unquestioned. I could exeuse his not getting on with his subalterns, for a man like Lumsden would spoil most men under him, at least for any other commander. Lumsden also seems to have left the accounts in great disorder, and Hodson has not gone about getting them right. . . Now I hear that all the European people dislike him, and that mischief may get up there. . . . To me, personally, he has always been amiable and most courteous, but I would give a good deal to see him elsewhere, for I fear a row." 1

It is clear from this letter that John Lawrence had been judging from hearsay rather than actual evidence on some of the points to which he refers. As far back as Deeember 1852 Hodson had written to his wife, "I am very busy here unravelling the confusion left by Lumsden." And we have seen how in a previous letter he had spoken of his

1 Bosworth Smith's 'Life of Lord Lawrence.' 
arduous efforts to organise and arrange in concert with his adjutant the economical details of the regiment. ${ }^{1}$

Among Hodson's enemies at this period none of his own household was to be numbered. In the words of his stepson, Major-General Mitford, he was " most kind to his servants, \&c. His bearer, Khudâ Baksh, was with me for a short time, and was then with my mother till she left India in March 1859. He was then made an inspector of the new Oudh Police, and frequently came to make his salaam and talk of his old master, which he did with the musual mixture of admiration and affection displayed by all the good natives who ever came under him. His personal orderly, Nihâl Singh, is another instance of the loving devotion he inspired. . . . While I was in Hodson's Horse I frequently profited by this. The men never called me anything but Chota Sahib, and it was by that title that they seated me on the Gadi at Amritsar when I was leaving India. It was done in memory of their old leader."2

The illness and death of his little girl marked the beginning of rery troublous times for Hodson himself. In his twofold capacity of soldier and civilian he had done things which brought him into collision with his official chiet's. His zeal for justice upon those who had plotted the death of Mackeson, and the murderous attack on Lieutenant Godby, had led him to seize and imprison a border chief named Khadar Khan, one of whose servants had dealt the blow which cut short Mackeson's career.

By Hodson's orders Khadar Khan's property was

1 See cliap. $x$.

2 Letter from Major-General Mitford. 
formally attached, and the chief himself held for several months in close arrest, pending his trial in the Commissioner's Court. In spite of the evidence which Hodson brought against him, the prisoner was acquitted. Nevertheless, Hodson's belief in Khadar Khan's guilt, a belief in which he did not stand alone, remained unshaken. "Since Khadar Khan has been out of jail," he writes, "there has been a renewal of the former state of uneasiness and excitement, and his people and emissaries are most active in intrigue. Tell Godby to look out for his friend, if he is really at Marri, and to remember that whatever Major Edwardes or any one else may say to the contrary, Khadar Khan, and no one else, was the author of the attack on him last December."

Major Edwardes reported the case to Lord Dalhousie as one of wrongful imprisonment, for which he could see no fair excuse. Acting upon Edwardes's version of the affair, the GovernorGeneral in the course of 1855 directed that Lieutenant Hodson should not again have any civil command in Yuzafzai. In reporting the matter to the Court of Directors, Lord Dalhousie said : "Lieutenant Hodsou's case has been lately before me. It is as bad as possible, and I have been compelled to remand him to his regiment with much regret, for he is a gallant soldier and an able man." In their letter approving the Governor-General's decision the Court of Directors decreed that Hodson should never again be employed in any civil capacity whatever.

As early as March 3, 1855, Hodson had been made aware of the fate in store for him by a private letter from the Chief Commissioner himself :- 
"My dear Hodson,--Since I last wrote to you I have received a letter from Government saying that you are not to resume command of the Guides, nor to have charge of Yuzafzai, and that your future employment will depend on the result of the court of inquiry. However disagreeable these tidings might be to you, I think you would prefer knowing them than waiting in suspense.-Yours truly, "John Lawrence." 1

The court of inquiry to which John Lawrence here refers had meanwhile been dealing with matters of far graver purport to Hodson's character than the wrongful imprisonment of a Pathan chief.

On September 8, 1854, Hodson had just heard from Major Macpherson, then military secretary to John Lawrence, that "there is to be a court of inquiry on the Turner affair or on me-I hardly know which. I am sorry for it in one sense, for these courts are vexatious and troublesome things, and it will give me much trouble; but as all is as clear as possible, I do not fear the result in the least-in fact, I would court inquiry rather than avoid it." 2 It appears that Turner, in spite of Hodson's peremptory orders, had refused to sign some regimental rolls on the ground of his disagreement with the remarks appended by his commanding officer. The letter in which Turner complained of Hodson's high-handed conduct was pronounced by Major Macpherson to be so "disgraceful to the writer that he dared not characterise it." This, however, was but one of many charges which

1 Papers supplied by Miss Hodson.

2 Letter to Mrs Hodson. 
Turner persisted in laying before the Chief Commissioner.

Hodson, for his part, was ready and eager to confront his accusers. "Pray impress," he wrote, "upon John Lawrence's mind that I am not in the smallest degree disposed to shrink from the strictest inquiry into any act of mine in the command of the Guides. I am much to blame for letting things go the length they did without bringing up - but that was good-natured folly, and neither dishonest nor unsoldier-like. It is true that I am annoyed at the trouble and bother of courts of inquiry, but nothing more; and if John Lawrence would come to overhaul everything connected with my command, I should be infinitely satisfied, and you may tell him so."

After a delay of sereral months the court of inquiry sat for the first time at Peshâwar in December 1854. Hodson had been ordered to make orer the command of the Guides to Lieutenant Godby, and to remain at Peshâwar during the sitting of the court. Among the charges which the court had to deal with were gross negligence and persistent falsification of accounts in matters specially concerning the command of the Guides.

The delay in assembling the court of inquiry had given time for the growth of many stories more or less untrue, but all alike hurtful to Hodson's good name. In the words of the Rev. C. Sloggett, afterwards chaplain of Dagshai, "There is no doubt that young Turner talked about all these things [his charges against Hodson] very freely in the Peshâwar society, and that the stories to Hodson's prejudice were eagerly caught up and circulated because of his 
general unpopularity." Of the causes which $\mathrm{Mr}$ Sloggett points out in detail mention has been made already; but one of them may here be emphasised in Mr Sloggett's own words: "He was a man of considerable attainments; a fair scholar; possessed of information above the average; and he was older than almost any one of his standing in the army. He was in this way superior to most of his fellows, and being at the same time naturally sarcastic and fearless, he would say and do things which galled men to the quick and made them hate him. Add to this the envy caused by his rapid rise owing to Sir Henry Lawrence's notice of him, and his unpopularity is accounted for. When, then, the committee of inquiry was ordered, and the members of it were at last all collected at Peshâwar,--some of whom arrived days or weeks before the whole could assemble in those days of slow and tedious travel, - these became infected with the prevailing prejudice to such a degree that they believed him guilty before the court assembled at all, and actually took possession of his regimental papers and accounts. Moreover, the native munshi and accountant, true to his national character, joined in and inflamed the stories against the fallen man." 1

The spirit in which some of Hodson's accusers conducted their case may be gathered from the fact that a regimental order published to the corps of Guides called upon all who had claims or complaints against their commandant to bring them forward without delay. This fact alone would account for the great number of witnesses, all native, who appeared before the court. "It is difficult to

${ }^{1}$ Quoted from a letter addressed to the Rev. G. H. Hodson. 
imagine," says a well-informed writer in "Blackwood,' " a course of procedure more grossly unfair or irregular, especially in India. . . . A similar order issued to a British regiment would probably have no effect except to arouse indignation at such means being resorted to in order to obtain evidence against a man already under a cloud. But with Orientals, or at least with the inferior classes of Orientals, the case is different. They have no compunctions whatever about hitting a man who is down; on the contrary, the knowledge that an officer had incurred the displeasure of his superiors, and had been suspended in consequence from his official position, would be the signal for every snivelling wretch who had a grudge against him to strive for a foremost place in throwing mud at him. . . Under such circumstances would Herbert Edwardes, would John Nicholson, have escaped scatheless?" 1

In this connection one cannot help recalling the language in which Macaulay characterised a similar process employed by Philip Francis against his great opponent Warren Hastings. "An Indian Government," says that brilliant essayist, "has only to let it be understood that it wishes a particular man to be ruined, and in twenty-four hours it will be furnished with grave charges, supported by depositions so full and circumstantial that any person unaccustomed to Asiatic mendacity would regard them as decisive. It is well if the signature of the destined victim is not counterfeited at the foot of some illegal compact."

"It must be remembered," says Major Reynell 1 'Blackwood's Magazine' for March 1899. 
Taylor, in his careful and exhaustive report of February 13, 1856, "that Lieutenant Godby, who had, I believe, been called upon to ascertain all claims that existed against Lieutenant Hodson with the regiment, gave public notice that all who had them to make must speak then or be silent afterwards. It is certain, therefore, that every one who thought he had a chance of gaining by coming forward did so; and it is a very important point in the case that it should be seen that there were no real complaints to be made on the score of pay."

The court, of which Colonel Halkett Craigie, C.B., was president, sat all through December 1854, and into the middle of the following January, hearing and recording a mass of evidence which, as events showed, was either wholly false or essentially worthless in its bearing on the character of the man accused. While the court was taking time to consider its verdict a cheering letter reached Hodson from Dr Lyell at Ghazipur. "When we parted," writes the good doctor, "I little thought that, notwithstanding all the quarrelling, any one would have had the audacity to bring such charges as you are now accused of against you. We all have our faults, and you, no doubt, have yours, but nothing shall ever persuade me that a man of your stamp has been guilty of what is alleged against you. I am sure any one who knows you would much sooner believe them to be a tissue of lies contrived by those rascally niggers to ruin you; so cheer up, old fellow, and for any sake do not abandon yourself to melancholy. . . . I have no doubt that though the odds seem against you, the malice of your enemies will be defeated, and that 
you will emerge from the cloud they have raised around you with untarnished reputation."

In this connection I may insert part of a letter which Lord Napier wrote in 1884 to the Rev. G. H. Hodson :-

"In March 1855, on visiting Peshâwar, I found the case of your brother under discussion at Sir J. Lawrence's headquarters. Feelings were very strong against him, and the loss of his appointment considered so certain that I feared the decision had been already made. I immediately sought your brother, and found him quite unconscious of his danger, and confident of clearing himself of the accusations brought against him.

"On his showing me his accounts, I saw they were all in Persian, liable to any misconstruction which an ill-disposed interpreter might place on them, and I urged him to translate them into English.

"He said it would take a fortnight, and I therefore rode back to Sir J. Lawrence's camp and asked him to allow that time for translating the accounts. To this he gave consent, which I carried at once to Hodson.

"By working day and night he accomplished the translation in the time.

"When it is remembered that on his being suspended, notice was given to every complainant to come forward against him, any one who knows the material contained in the Guides knows that there were men who might have had enmity to gratify, or hope of positive advantage in bringing accusations before the court of inquiry."

The proceedings of the court of inquiry had been 
conducted in so rambling and loose a manner as to elicit a very sharp rebuke from the Judge AdvocateGeneral, who returned the papers to Colonel Craigie with a request for some definite opinion upon the matters which his court had been directed to consider. The court of inquiry thereupon reassembled in July, and after hearing Godby's evidence, proceeded in Hodson's absence to record their opinion that the accounts of the Guides as laid before it by Lieutenant Hodson were most unsatisfactory.

On this occasion the accused officer had not been heard in his own defence. Being unable to prepare a full written statement within the time allowed him, he had asked leave to attend the court in person and submit his accounts for their inspection. To this request no answer was given, and the result, as Hodson himself declared, was that he had been "the subject of an inquiry at which I was not present, and of proceedings of the nature of which I am ignorant save by report." ${ }^{1}$

Meanwhile Hodson had pleaded again and again for a more searching inquiry into the accounts of the Guides than that which the court had been misconducting. In the summer of 1855 he sent to the Chief Commissioner his demand for a courtmartial. On learning from John Lawrence that his letter had been mislaid he repeated his demand.

"My dear Lawrence," he writes in October,- " I send herewith the copy of my letter asking for a court-martial which you desired. Since I wrote it Turner has started for Bombay. I trust this will

${ }^{1}$ Letter to Colonel H. Tucker, C.B., Adjutant-General, September 14,1855 . 
not prevent my wish for a fair trial being granted. My accuser's were not called on to substantiate their assertions.

"The burden of disproof, proverbially an arduous task, was thrown upon me. At the same time the court, by rejecting my accounts, absolutely deprived me of the means of replying satisfactority to the false accusations brought against me. This could not again occur. Taylor's examination, backed by the court of inquiry suggested by the commanderin-chief, will remove all doubt from the accounts and afford me the materials for clearing myself.

"I have been cruelly misrepresented in other ways. Many things have been told you of me, and have doubtless influenced your judgment of my case, which would be either disproved or explained by inquiry.

"All I ask for is a full and public examination of the whole case or allegations against me. I do not fear the result. I trust you will obtain such an examination or trial for me from Government." I

The Taylor to whom this letter refers was Major Reynell Taylor,- " the Bayard of the Punjâb,"who had made his mark as one of Henry Lawrence's men in the second Sikh war, and had afterwards done good work as Deputy Commissioner of Bannu. $\mathrm{He}$ had lately returned from furlough in time to take over, at Dalhousie's bidding, the temporary command of the Guides. In the autumn of 1855 John Lawrence instructed him to examine and report upon Hodson's alleged misdealings with the regimental chest. Reynell Taylor set himself man-

1 Letter supplied by Miss Hodson. 
fully to carry through a task which at the outset he did not greatly relish. Turner had gone to Bombay, where he died in the following January. But Godby was at hand to help Taylor in overhauling the regimental books, and to point out the discrepancies, blunders, and omissions which seemed to tell against his former commandant.

It was truly a tangled skein which Reynell Taylor essayed to unravel. Day after day, with Hodson at one elbow and Godby at the other, he toiled through the chaotic mass of documents, English and Persian, which professed to show forth the sums received and disbursed by Hodson himself from month to month for nearly two years on account of the Guide Corps. ${ }^{1}$ The scrutiny which thus began at Mardân in August 1855 ended only in the last days of October.

On November 2 Taylor wrote to inform the military secretary that he had completed the examination of the accounts. "Lieutenant Hodson is very anxious, as his accounts have been publicly challenged, that they should be finally examined and reported on by an officially appointed court of inquiry, Najaf Ali to be present." This man was a regimental munshi who bore Hodson a special grudge, and had been one of his principal accusers. "As some of Najaf Ali's assertions," continues Taylor, "are capable of very clear disproof from the retrenchment papers in the office, I do not think it likely that his attendance will be procured without the assistance of the civil authorities. . . . I have,

1 It was not till March 1853 that Hodson took over the sole management of the accounts from his adjutant, Lieutenant F. M'C. Turner. 
in company with Lieutenant Godby, and with considerable labour, gone through the whole, item by item, and am quite satisfied that all is correct, . . . and all will be set right without difficulty."

In the course of November Taylor sat down to write a full and detailed report on the case which he had so patiently investigated. This careful and conscientious piece of work, a copy of which will be found in the Appendix, ${ }^{1}$ was completed on February 13,1856 , and forwarded at once to the Chief Commissioner. He began by declaring that the result of his examination of Lieutenant Hodson's accounts had been "quite satisfactory." After detailing through many pages a clear and impartial statement of the facts disclosed by his researches-of the manner in which the accounts had been kept before Hodson assumed command; the difficulties with which a commandant of the Guides had to contend, owing to his multifarious duties and the many services demanded of his troops, - - he pointed out the further complications arising from the delays and irregularities of the accounts department, and the efforts made by Hodson to deal with all these complications to the best of his power.

Speaking of the accounts when Hodson entered on his command, Taylor shows that "everything was known to be in the main correct, but the whole unbalanced and undetailed, and it must be recorded that he did not, on first obtaining command of the Guides, formally examine and take charge of the accounts. He had long been connected with the regiment, and knew all the difficulty and confusion

${ }^{1}$ See Appendix A, p. 356. 
that had been caused in its payment by a long period of ubiquitous service, during which its numerous detachments had been paid by the various officers to whom they had been temporarily attached, causing a constant and most troublesome system of adjustment from the headquarters, which latter were also usually on the move, and the commanding officer obliged to take frequent advances from political or civil treasuries."

"Such is the account," wrote Taylor towards the close of his report. "I may briefly sum up my opinion by saying that I believe it to be an honest and correct record from beginning to end. It has been irregularly kept, but every transaction, from the least to the greatest, has been noted in it, and is traceable to the individuals concerned; for it must be remembered that while we have been sitting in committee on the accounts at Mardân, nearly every man mentioned in the transactions of the chest has been present with the regiment, and throughout the inquiry I have found Lieutenant Hodson's statements borne out by the facts of the case, while in some instances, where doubts had been engendered by a want of knowledge of details, they were removed by working through the minutiæ of the account."

In his closing paragraph Taylor says that "Lieutenant Godby, who assisted me throughout the laborious examination of the accounts with a wish to understand them himself and do Lieutenant Hodson every justice, appends a certificate to this statement, to the effect that he is perfectly satisfied with regard to the correctness of the whole account."

Orer the result of Taylor's report no one rejoiced 
more sincerely than Hodson's old friend Colonel (afterwards Lord) Napier. "The result," he wrote, "of Major Taylor's laborious and patient investigation has fully justified, but has not at all added to, the confidence that I have throughout maintained in the honour and uprightness of his conduct." 1 Nor was Robert Montgomery less cordial in his acceptance of Taylor's finding. "To me the whole report seemed more satisfactory than any one I had ever read; and considering Major Taylor's high character, patience, and discermment, and the lengthened period he took to investigate every detail, most triumphant. This I have expressed to all with whom I have conversed on the subject."

Hardly had Taylor set to work on his report when he wrote to the Chief Commissioner in December 1855 , suggesting that as so much publicity had been given to the previous court of inquiry which had reported unfarourably to Hodson, a similarly public court should again assemble to consider the results of his own investigations. To so reasonable a suggestion the authorities turned a deaf ear. It is true that the Chief Commissioner yielded at one time to Taylor's urgency, and advised the commander-inchief to grant the further inquiry which Taylor and Hodson agreed in desiring. But Sir William Gomm held to his own view that neither a court nor a committee of inquiry was necessary, since Major Taylor was willing to grant Lieutenant Hodson a full acquittance on all points connected with his accounts. The Chief Commissioner seems to have concurred in this view.

The whole matter was then laid before the 1 Quoted in 'Blackwood's Magazine' for March 1899. 
Government of India, and this was the answer forwarded by Colonel Birch to the AdjutantGeneral on December 22, 1855: "I am directed to acquaint youl, for the information of the commander-in-chief, that the Most Noble the GovernorGeneral in Council concur's in opinion with his Excellency that further proceedings on the point [of Hodson's accounts] are unnecessary, and his lordship in Council would accordingly allow Lieutenant Hodson to receive the acquittance, and thus close this harassing and painful business."

The final decision upon Hodson's case was thus reported to the Court of Directors by the new Governor - General, Lord Canning, on March 13, 1856 :-

"Your honourable Court will observe that we have felt compelled to place Lieutenant Hodson at the disposal of his Excellency the commander-inchief.

"After haring giren our attentive consideration to all the circumstances connected with this case, we have, in concurrence with the opinion of his Excellency the commander-in-chief, General Sir W. Gomm, K.C.B., decided that as Major Taylor, the officiating commandant of the corps of Guides, was willing to grant an acquittance to Lieutenant Hodson on all points connected with his accounts, further proceedings in the matter were unnecessary, and we have accordingly allowed that officer to receive the acquittance, and have thus closed this case."

By this time Taylor's full report had been laid before the Chief Commissioner, Sir John Lawrence, who forwarded it in due course to Simla. No 
action, however, seems to have been taken by the Indian Government beyond a brief note by one of the secretaries, and the briefer comment of a member of Council. It is almost certain that the report was never shown either to the Governor-General or the commander-in-chief. In short, as a trustworthy correspondent assures me, "it was filed and put away, nor was seen again apparently by any one till I had it dug out." 1

This chapter may fitly close with the following passage from the article to which I have already referred: "All the world knew that a court of inquiry had sat to examine Hodson's accounts,-all the world knew that Hodson was removed from the command of the Guides; but the world did not know, and to this day does not know, that the second fact was in no way consequent on the first. It is not known that (as was written by Colonel Macpherson, military secretary to the Punjâb Government) 'the military court of inquiry had nothing whatever to say to, and was in no way concerned with, the removal of the late Major (then Lieutenant) Hodson from the command of the Guides'; and again, 'In so far' as the court of inquiry was concerned, Major Hodson, had he survived, might perhaps have commanded the corps of Guides to this day.' Nor is it generally known, except by hearsay, how extraordinarily convincing a proof of Hodson's innocence of all the charges affecting his honour is Taylor's detailed report." 2

1 Private letter of September 9, 1899.

2 'Blackwood's Magazine' for March 1899. 


\section{CHAPTER XII.}

WAITING FOR BETTER TIMES. 1856-1857.

IT is needless here to speculate on the hidden causes which baffled all Reynell Taylor's efforts to win for Hodson a public and impartial re-hearing of the case which he himself had gone through so carefully with a single eye for the truth. In the virtual suppression of his final report we may see the fitting sequel to the previous injustice. Hodson's character had been cleared of all reproach by one of the noblest and most capable officers in the Company's service, who had himself been somewhat prejudiced against the accused by the stories at that time current at Peshâwar.

"The investigation by Reynell Taylor was complete and searching, occupying as it did many months," wrote Lord Napier to the Rev. G. H. Hodson in 1884. "No man of higher honour or ability could have been chosen for such a duty, high-minded, pure in character, painstaking, and indefatigable.

"That Hodson's full acquittal from the inquiry was not at once accepted and acknowledged, I considered then, and consider still, a grievous wrong. Your brother was left for many months exposed to 
all the discredit of accusations made against him, and greatly exaggerated by rumours, while his judges' farourable verdict was reserved. To this course I attribute the prejudice against him on the part of many who listened too easily to stories to his discredit.

"Though not agreeing with your brother in all things, I never doubted his honour and integrity, and I maintain my full belief in them now. Those who thought otherwise might have left undisturbed the grave of a gallant soldier who had fought so bravely and successfully for his country." 1

In common justice to both the officers specially concerned, the result of Taylor's private but official inquiry into Hodson's alleged misuse of public moneys ought to have been made at least as widely known as the charges laid before Colonel Craigie's court. But in spite of 'Taylor's exculpatory verdict, the mischief wrought by official reticence was allowed to reap its inevitable harvest.

It was known that Hodson had been removed from the command of the Guides, but it does not seem to have been generally known that the cause of this removal was to be found, not in his dealings with the regimental accounts, but only in his highhanded treatment of Khadir Khan. It is not surprising, therefore, that many of those who bore him no personal grudge should have accepted that darker version of the facts which his enemies were prompt to circulate, and that even Taylor's character for shrewdness and impartiality should have been called in question by those who had never studied his report.

1 Hodson of Hodson's Horse. 
It seems also clear that to the same cause may be ascribed that further crop of stories which in after-years represented Hodson as a past-master in the art of enriching himself at other people's expense.

In January 1856, while Hodson and his wife were staying at Peshâwar, they were cheered by a visit from her son, young Reveley Mitford, now a retired major-general, who had come thither on leave, pending the result of his application to be transferred from the 9th Native Infantry to the 3rd Bengal Europeans, then stationed at Agra. Hodson and his stepson often acted as gallopers on field-days to Brigadier (afterwards Sir Sydney) Cotton. On one occasion, writes General Mitford, "Hodson wanted to have a talk with the officer commanding Fort Michni, and I rode out with him and had tiffin at the fort, where I myself commanded in 1877. We stayed rather late, and did not leave till sundown. There was then only a track between Peshâwar and Michni, thirteen miles, frequently crossing dry nullahs and running through tracts of brushwood and scrub. We were approaching one of these nullahs when I called Hodson's attention to some sparks on the opposite bank; he at once said, 'Keep quiet and follow me.' We turned off at right angles, and immediately three shots were fired at us, and I heard for the first time the 'ping' of a bullet. 'That's all right,' said Hodson, 'now we know where they are.' We crossed the nullah lower down and regained the track by a circuitous route. All he said about it was, 'Don't tell your mother-it will only make her anxious.'"

In the spring of the same year Mitford marched 
down with the Hodsons to Ambâla. "At Lahore," adds my informant, "he took me to see many of the Sikh sirdars, who seemed devoted to him. Old Tej Singh lent his four best mules to 'horse' the ghâri to Amritsar. On arriving at Ambâla I left them to join my regiment at Agra." Hodson himself made his way to the hill station of Dagshai, and quietly resumed his place as regimental subaltern in the 1st Bengal Fusiliers. In passing through Ambâla he had been "much gratified by an unexpected visit from $\mathrm{Mr}$ Charles Raikes, one of the Punjâb Commissioners, who was passing through Ambâla on his way to take a high appointment at Agra. I had no personal knowledge of him, but he came out of his way to call upon me, and express his sympathy and appreciation of (what he was pleased to call) my high character.

"He said much that was encouraging and pleasing, which I need not repeat. It served pleasantly, however, to show that the tide was turning, and that in good men's minds my character stood as high as ever."

It must not be supposed that a man of Hodson's stamp would accept without a struggle the sentence passed upon him by the Indian Government in respect of the Khadir Khan affair. In the midst of his efforts to clear himself from blame concerning the regimental accounts of the Guides, he had consulted one at least of his friends as to the best means of obtaining redress for what he honestly considered a grievous wrong. The answer he received from Robert Montgomery in November 1855 was not encouraging: "I do not think you can do anything regarding Khadir Khan's case. The 
Supreme Court would not interfere in a public and official representation made to the GovernorGeneral and accepted by him. You could not appeal to me. ${ }^{1}$ You might appeal to the Court of Directors if you consider you have been unfairly dealt with. In this country you cannot succeed, and there is no use in your trying. To the Court you can alone go; but I do not say whether you ought or not. I an sincerely glad to learn from your extract what Major Taylor thinks of your accounts. It is, indeed, a triumph for you, and ought to go far in clearing you with your superiors. You have passed through a severe ordeal, and I hope better times are in store for you. I saw your father's death in the papers, and can well believe how much you feel his loss."

The death from cholera of his father, the good old Archdeacon of Stafford, had occurred some weeks before at Riva, whither he had gone for a month's rest and change of air. "The blow," he wrote to his sister, "was overwhelming; coming, too, at a time of unprecedented suffering and trial, it was hard to bear up against. What a year this has been! What ages of trial and of sorrow seem to have been crowded into a few short months! Our darling babe was taken from us on the day my public misfortunes began, and death has robbed us of our father before their end. The brainpressure was almost too much for me, coming as the tidings did at a time of peculiar distress. . . . The whole, indeed, is so peculiarly sad that one's heart seems chilled and dulled by the very horror of the calamity."

1 Montgomery was then Judicial Commissioner for the Punjâb. 
Hodson's health, which had been severely tried by the pressure of his recent troubles, soon began to recover itself in the bracing air of a station 7000 feet above the sea. "This is a great thing," he writes on April 8, "but it is very hard to begin again as a regimental subaltern after nearly eleven years' hard work. However, I am very fond of the profession, and there is much to be done and much learnt, and under any other circumstances I should not regret being with English soldiers again for a time. Every one believes that I shall soon be righted, but the 'soon' is a long time coming."

Among those who received him with special kindliness was the officer commanding his regiment, Colonel John Welchman, who had led the lst Fusiliers with honour through all the fighting and hardships of the second Burmese war. His sympathies had already been won in Hodson's favour by the letter which Colonel Robert Napier had addressed him from Ambâla a few days before Hodson reached Dagshai. It is worth inserting at full length :-

"My dear Colonel Welchman,-I have great pleasure in meeting your request, to state in writing my opinion regarding my friend Lieutenant Hodson's case. Having been on intimate terms of friendship with him since 1846 , I was quite unprepared for the reports to his disadvantage which were circulated, and had no hesitation in pronouncing my utter disbelief in, and repudiation of, them as being at variance with everything I had ever known of his character. On arriving at Peshâwar in March 1855 I found that Lieutenant Hodson had been undergoing a course of inquiry before a special military 
court, and on reading a copy of the proceedings I perceived at once that the whole case lay in the correctness of his regimental accounts; that his being summoned before a court, after suspension from civil and military duty, and after an open invitation (under regimental authority) to all complainants in his regiment, was a most unusual ordeal, such as no man could be subjected to without the greatest disadvantage; and notwithstanding this, the proceedings did not contain a single substantial case against him, provided he could establish the validity of his regimental accounts; and that he could do this I felt more than confident.

"The result of Major Taylor's laborious and patient investigation of Lieutenant Hodson's regimental accounts has fully justified, but has not at all added to, the confidence that $I$ have throughout maintained in the honour and uprightness of his conduct. It has, however, shown (what I believed, but had not the same means of judging of) how much labour Lieutenant Hodson bestowed in putting the affairs of his regiment in order. Having seen a great deal of the manner in which the Guide Corps has been employed, I can well understand how difficult it has been to maintain anything like regularity of office, and how impossible it may be for those who remain quietly in stations with efficient establishments to understand or make allowance for the difficulties and irregularities entailed by rapid movements on service, and want of proper office means in adjusting accounts for which no organised system had been established. The manner in which Lieutenant Hodson has elucidated his accounts since he had access to the 
necessary sources of information appears to be highly creditable. I have twice had the good fortune to have been associated with him on military service, when his high qualities commanded admiration. I heartily rejoice, therefore, both as a friend and as a member of the service, 'at his vindication from most grievous and unjust imputations.' And while I congratulate the regiment on his return to it, I regret that one of the best swords should be withdrawn from the frontier service.Yours very sincerely,

R. NAPIER." 1

The warmth and clearness of Napier's pleadings on behalf of his old comrade impelled Colonel Welchman to give Hodson the post of quartermaster to his regiment. About this time, however, he had contrived to dislocate one of his ankles by a fall from the roof of a lower room in his house.

"I am just able," he writes on July 31 to the Rev. F. A. Foster, " at the end of upwards of fifteen weeks, to walk with the aid of a stick and discard my crutches. The constant recumbent attitude was not provocative to writing, and there was much which I was bound to attend to, being a regimental staff officer now with a great deal of responsibility. I can give you very little good news as far as I am concerned, I grieve to say. Although the result of the inquiry which I so long demanded in vain into my regimental finance accounts of the Guide Corps was pronounced to be 'triumphant,' no notice whatever has been taken of it by Government. The powerful hostility of the Punjâb Government, which provoked and invited the attack upon me, has been

1 Hodson of Hodson's Horse. 
too strong to allow the most ordinary justice to be done me as yet, though public feeling (as far as there is any such thing in India) has been manifested most strongly and in a very gratifying manner in my favour. What the result may be eventually it is impossible to foresee! My ruin in the meantime is absolute and complete. Two years ago I was in the most envied position on the frontier -commanding a distinguished regiment, which I had helped to raise and form, and which I had myself instructed, and governing an important district; and I was in receipt of a hardly earned (but honourably earned) income of $£ 1200$ a-year. I am now a regimental subaltern on $£ 300$, or rather $£ 250$, a-year! And all this without fault of mine, but simply from the bitter enmity of one man whose official position gave him the long-sought opportunity of gratifying his rage.

"However, I trust I am too much of a soldier to permit myself to be subdued by reverses, or to sit down and fret over the irremediable past. There is much to do-some good, I trust, to be effected-and much to be learnt in this regiment, and I am not sorry, per se, to have the opportunity of being more amongst English soldiers than I have been of late years. I do not say, however, that I do not feel the reverse most keenly. It is a great comfort, though, to feel that I have nothing to be ashamed of, nothing to look back upon I would wish concealed from my friends or the world. Of course I admit that there are many things in which I might with present experience have acted differently, perhaps more wisely and more well. To which of us does it happen on reviewing his past life to say, "Were I to live over' 
the past ten years again, I would do precisely as I have done, untaught by the past'? But one thing I can say, that I have acted to the best of my powers, for what I believed to be the true interests of those committed to my charge, without selfishness or self-seeking, and that I never sacrificed what I believed to be my duty to any private feelings or considerations whatever. The blow has been, as you may conceive, a very bitter one for my darling wife: she naturally feels the reverse most acutely, and coming as it did upon the terrible grief we had to bear in the loss of our only babe, her life has been terribly embittered, nor has her health escaped uninjured. For myself, I have to be thankful for good health, and that I am quartered in a healthy hill climate near Simla."

In the latter part of September he was getting a little stronger upon his ankle, but still unable to do more than walk about the house.

On November 6 he writes of his yearning for a visit home: "But I am obliged to check all such repinings and longings, and keep down all canker cares and bitternesses, and set my teeth hard, and will earnestly to struggle on and do my allotted work as well and cheerfully as may be, satisfied that in the end a brighter time will come."

He still caught at every opportunity of trying to get justice done him by the Punjâb Government. But the following letter from Captain Richard Lawrence closed the door to all further efforts in that direction :-

"November 20.

"My dear Hodson,-I duly laid your letter before the Chief Commissioner, and he desires me to 
intimate to you that he objects to again address Government regarding your case, as he does not see how he could do so with propriety. I should have been glad had it been in my power to assist you in this matter."

In spite of his maimed ankle and of mental worries which might well have soured the sweetest nature, he set himself to discharge his regimental duties with a zeal and an energy which elicited the warmest praise from his commanding officer. On January 18, 1857, Colonel Welchman addressed the following appeal to the adjutant-general of the army :-

"I consider it a duty, and at the same time feel a great pleasure, in requesting you to submit, for the consideration of his Excellency the commanderin-chief, this my public record and acknowledgment of the very essential service Lieutenant Hodson has done the regiment at my especial request. On the arrival of the regiment at Dagshai I asked Lieutenant Hodson to act as quartermaster. I pointed out to him that, mainly owing to a rapid succession of quartermasters when the regiment was on field-service, the office had fallen into very great disorder; ... . and that he would have to restore order out of complicated disorder, and to organise a more efficient working system for future guidance and observance. To my great relief and satisfaction, Lieutenant Hodson most cheerfully undertook the onerous duties: he was suffering at the same time severe bodily pain, consequent on a serious accident, yet this did not in any way damp his energy or 
prevent his most successfully carrying out the object in view. . . . It is impossible to do otherwise than believe that this officer's numerous qualifications are virtually lost to the State by his being employed as a regimental subaltern, as he is fitted for, and capable of doing great justice to, any staff situation ; and I am convinced that, should his Excellency receive with approval this solicitation to confer on him some appointment suited to the high ability, energy, and zeal which I fear I have but imperfectly brought to notice, it would be as highly advantageous to the service as gratifying to myself. An officer whose superior mental acquirements are fully acknowledged by all who know him; who has ably performed the duties of a ciril magistrate in a disturbed district; whose knowledge of engineering has been practically brought into play in the construction of a fort on the north-western frontier; whose gallant conduct in command of a regiment in many a smart engagement has been so highly commended, and by such competent authorities,-is one whom I have confidence in recommending for advancement: and in earnestly, yet most respectfully, pressing the recommendation, I plead this officer's high qualifications as my best apology. . . . -I have, \&c., J. Welchman, Lieut.-Col.

Commanding 1st Bengal Fusiliers."

The 1st Fusiliers had gone down to Ambâla to take part in the winter camp of exercise under Brigadier-General Johnstone, commanding the Sirhind Division. In appending his counter-signature to Welchman's appeal, the Brigadier-General begged " to accompany Colonel Welchman's letter with a 
testimony of my own to the high character of the officer in question.

"Rejoining his regiment as a lieutenant, from the exercise of an important command calling daily for the display of his energy, activity, and self-reliance, and frequently for the manifestation of the highest qualities of the partisan leader or of the regular soldier, Lieutenant Hodson with patience, perseverance, and zeal undertook and carried out the laborious minor duties of the regimental staff as well as those of a company; and with a diligence, method, and accuracy, such as the best trained regimental officers have never surpassed, succeeded in a manner fully justifying the high commendation bestowed on him by his commanding officer. As a soldier in the field Lieutenant Hodson has gained the applause of officers of the highest reputation, eyewitnesses of his ability and courage. On the testimony of others I refer to these, and that testimony so honourable to his name I beg herewith to submit to his Excellency.

"On my own observation I am enabled to speak to Lieutenant Hodson's character and qualities in quarters, and I do so in terms of well-earned commendation, and at the same time in the earnest hope that his merits and qualifications will obtain for him such favour and preferment at the hands of his Excellency as he may deem fit to bestow on this deserving officer."

To an appeal so just, so earnestly worded, no answer appears to have come from Sir William Gomm's headquarters. Meanwhile a new hope had dawned for Hodson with the breaking out of war between Persia and the Government of India. 
Could Sir Henry Lawrence help him to retrieve his broken fortunes by means of soldierly service with the army which Outram had been selected to command? His letter to Sir Henry, who had just been appointed Chief Commissioner for Oudh, at once drew forth from his old friend the following answer :-

“Lucknow, March 21, 1857.

"The day I received your letter I answered it, but have my reply still in my desk, as I feared it might raise undue hopes. The fact is, I doubt if any man could help you just now, and were I to be refused once it might prevent me helping you hereafter. I have therefore also kept back a chit [Anglice, note] I wrote to Colonel Birch about you, recommending you for Persia. If the campaign lasts I will try and get you there, as I know no better sword than yours. I should think that either General Outram or Jacob would appreciate you."

Early in April Hodson was back again in Dagshai, whence on the 7th he wrote to his brother: "Your letter written this day three months reached me at Ambâla, at our mildest of Chobhams, ${ }^{1}$ in the middle of February, and deserved an earlier reply; but I have been taken quite out of the private-correspondence line lately by incessant calls on my time. Regimental work in camp in India with European regiments, no less than in quarters, is contrived to cut up one's time into infinitesimal quantities, and keep one waiting for every other half-hour through the day. I had more time for writing when I commanded a frontier regiment and governed a proI At Chobham, in Surrey, was held the first camp of exercise in 1854. 
vince! These winter camps are very profitable, however, and not by any means unpleasant; and as Ambâla was very full, we had an unusual amount of society for India, and some very pleasant meetings. I was too lame to dance, but not to dine and take part in charades or tableaux and so forth, and so contrived to keep alive after the day's work was over. I got some kudos and vast kindness for performing the more strictly professional rôle of brigade-major to one of the infantry brigades, and had excellent opportunities of learning the essential, but so seldom taught or learned, art of manœuvring bodies of troops. My service has been so much on the frontier and with detached corps that I had previously had but small opportunities for the study."

In the same letter he goes on to describe the result of his first interview with General Anson, the new commander-in-chief: " $\mathrm{He}$ is a very pleasantmannered and gentlemanly man, open and frank in speech, and quick to a proverb in apprehension, taking in the pith of a matter at a glance. As I always thought, it turned out that Major 'Taylor's report had never reached the commander-in-chief, and they had only the old one-sided story to go upon. I explained the whole to him, and as he had already very kindly read the papers relating to the matter, he quite comprehended it, and begged me to give him a copy of Taylor's report, when he would, if satisfied, try and see justice done me. I trust, therefore, that at last something will be done to clear me from all stigma in the matter. As soon as that is done he will give me some appointment or other, unless Government do it themselves."

The opportunity for which he was so anxiously 
waiting was at that moment very near at hand. The shadows of a great sepoy mutiny were already falling over the land: "We are in a state of some anxiety owing to the spread of a very serious spirit of disaffection among the sepoy army. One regiment (the 19th of the line) has already been disbanded, and if all have their dues, more yet will be so before long. It is our great danger in India ; and Lord Hardinge's prophecy, that our biggest fight in India would be with our own army, seems not unlikely to be realised, and that before long. Native papers, education, and progress are against keeping 200,000 native mercenaries in hand."

In the latter part of April Hodson went up to Simla for the purpose of pleading his cause with the commander-in-chief.

On the 22nd he writes to his wife-

"I am just come back from hunting about ever since breakfast and seeing the big-wigs too late for to-day's post, but I will begin this before it be too late to see.

"I found an invitation for to-night to dinner awaiting me from General Anson. I have seen Colonel Curzon, and he says that though the general has not yet read the memorandum or report, yet he will do so while I am here, and see me also before I go down again.

"He will mention to the general my plan of going to Calcutta, and says there can be no doubt but that the general will say 'Go.'

"I have since seen Colonel Chester (our adjutantgeneral), the way having been kindly smoothed for me by $\mathrm{Mr}$ Sloggett. ${ }^{1}$ His mind was a blank ${ }^{1}$ Then military chaplain at Dagshai. 
regarding the whole affair, having never heard a word about it owing to his absence in England at the time. He only knew that I had lost my appointment-was most kind and interested, and listened to my résumé of the case. He has promised to read all the papers, and asked for Taylor's report (which of course he had never heard of) and my memorandum, both which I have given him, with Colonel Napier's letter. He has the usual high opinion of Taylor, and was much satisfied to hear Montgomery's opinion. You see at present all goes well. Chester, I should add, very strongly advises the Calcutta plan, and says Lord Canning is a most just man, and would not, if he knew it, allow an injustice to be continued."

It had now, in fact, become Hodson's fixed intention to go down to Calcutta and lay his case in person before the Governor-General. "There were clearly three courses open to me, ' $a$ la Sir Robert Peel': 1st, suicide; 2nd, to resign the service in disgust and join the enemy; 3rd, to make the Governor-General eat his words and apologise. I chose the last. The first was too melodramatic and foreign; the second would have been a triumph to my foes in the Punjâb,-besides, the enemy might have been beaten! I have determined, therefore, on a trip to Calcutta."

Meanwhile he had had another interview with General Anson at Simla. "Nothing," he wrote to his brother, "could have been more satisfactory. He was most polite, eren cordial, and while he approved of my suggestion of going down to Calcutta to have personal explanations with the people there, and evidently thought it a plucky 
idea to undertake a journey of 2500 miles in such weather (May and June), yet he said that I had better wait till I heard again from him, for he would write himself to Lord Canning and try to get justice done me.

"I do trust the light is breaking through the darkness, and that before long I may have good news to send you, in which I am sure you will rejoice."

It was fortunate for Hodson, and indeed for all India, that by Anson's advice he waited on at Dagshai until the answer from Calcutta should reach the commander-in-chief. "I should undoubtedly have been murdered at some station on the road," he afterwards said. "The answer never came. It must have been between Calcutta and Aligarh when disturbances broke out, and was, with all the daks for many days, destroyed or plundered."

Hodson's opportunity had come at last: how gloriously he rose to it the reader will learn in the following chapters. 


\section{CHAPTER XIII.}

THE GREAT MUTINY-FIRST WEEKS OF THE SIEGE OF DELHI. MAY-JUNE.

Among Hodson's staunchest friends at this period was the Rev. C. Sloggett, chaplain of Dagshai. As early as April 1857 Hodson had laid before the rev. chaplain a written statement of his case which embodied Reynell Taylor's report. Mr Sloggett was so greatly impressed by the force and clearness of this document that he offered to show it to his "dear friend Colonel Chester," with whom he was going to spend a few days at Simla.

"He kindly looked over it," says Mr Sloggett, "at my earnest request, and while doing this the judge advocate-general, Colonel Keith Young, came into the room and took part in our conversation. He too, like the many men who have made the reputation and greatness of our Indian Government, was possessed of the highest honour and integrity, and at first he spoke to me with scorn respecting the case. The whole matter, he said, had passed under his own review ere it had been submitted to Government, and the verdict of the court was amply justified by the evidence produced. But here Colonel Chester interposed by telling him of this 
new light thrown upon it, and I left them to go through it together. When they had done so they were evidently much impressed by it. Colonel Chester promised to show it at once to the commander-in-chief, General Anson, and Keith Young thanked me very warmly for bringing it under his notice. From that time Keith Young became one of Hodson's warmest friends, and General Anson was prevailed on by both of them to give him another appointment. Then, of course, the idea only was that he should write on the matter to Lord Canning, which I believe he did; but the letter was lost in transmission through the sudden outbreak of the rebellion.

"It was, I think, just a week after I spoke to them that the Mutiny broke out at Meerut, and for months afterwards there was no direct postal communication with Calcutta. General Anson, therefore, gave Hodson a staff appointment on his own responsibility, and he soon justified the selection, for it is doubtful if there was another man in the whole army who could have supplied his place." 1

The hour, indeed, was drawing very near when every Englishman from Peshâwar to Calcutta would learn with incredulous surprise the first tidings of a successful sepoy rising in one of the most important stations of Upper India. When news of the murderous outbreak at Meerut on May 10 was first flashed up and down the telegraph wires, it seemed hardly credible that such a thing could have happened in a cantonment guarded by two strong European regiments and several batteries

${ }^{1} \mathrm{Mr}$ Sloggett's letter to the Rev. G. H. Hodson, 1882. 
of artillery. But worse still was to come, for on May 11 the mutineers from Meerut had entered the imperial city of Delhi. In a few hours all Delhi was up against our helpless countrymen, who little dreamed that not a hand from Meerut would be stretched forth to succour them. English men, women, and children were cruelly butchered within the palace itself, within sight or hearing of the old king, who owed to our forbearance all the dignities and comforts he still enjoyed. Before sunset all Delhi was in the hands of the mutineers.

Soon after nightfall of that sorrowful Monday the weary watchers by the Flagstaff Tower, on a rocky ridge that ran between the city and the cantonments, set out in scattered parties, by carriage, on horseback, or on foot, along any road that might lead them far away from the sight of their blazing bungalows and the yells of ruffians thirsting for more Farangi blood.

As soon as the tidings of this twofold tragedy reached Simla the commander-in-chief issued orders for the prompt despatch of the white troops that garrisoned the hill-stations of Kussowlie, Dagshai, and Sabâthu. Hodson marched with his regiment down to Umbâla, where Anson himself arrived on Nay 15, in order to collect a force strong enough to act promptly against the mutineers. In that moment of supreme danger William Hodson came once more to the front. On the 16th Anson made him assistant quartermaster-general to the force which he himself was preparing to lead to Delhi. $\mathrm{He}$ empowered Hodson to raise 1000 irregular horse, placed him at the head of the Intelligence Department, and sent him on to Karnâl for the 
purpose of restoring communications between that place and Meerut.

In addition to this latter task Hodson was intrusted with special despatches from General Anson to the officer commanding at Meerut, of whose movements nothing had been heard since the outbreak of May 10.

After arranging matters at Karnâl he started for Meerut on May 20 at the head of a troop of Sikh horse supplied by the loyal Rajah of Jhind. Seventy-two hours later he was back again in Karnâl telegraphing to his chief that "I had forced my way to Meerut, and obtained all the papers he wanted from the general there. These I gave him four hours later in Umbâla. The pace pleased him, I fancy, for he ordered me to raise a corps of irregular horse, and appointed me commandant." "

What others thought of this daring ride may be gathered from the following letter, written by an officer in the Meerut garrison: "When the Mutiny broke out our communications were completely cut off. One night, on outlying picket at Meerut, this subject being discussed, I said, 'Hodson is at Umbâla, I know; and I'll bet he will force his way through, and open communications with the commander-in-chief and ourselves.' At about three that morning I heard my advanced sentries firing. I rode off to see what was the matter, and they told me that a part of the enemy's cavalry had approached their post. When day broke in galloped Hodson. He had left Karnâl (seventy-six miles off) at nine the night before with one led horse and an escort of Sikh cavalry, and, as

1 Letter to Colonel Douglas Seaton. 
I had anticipated, here he was with despatches for Wilson! How I quizzed him for approaching an armed post at night without knowing the parole! Hodson rode straight to Wilson, had his interview, a bath, breakfast, and two hours' sleep, and then rode back the seventy-six miles, and had to fight his way for about thirty miles of the distance."

Another officer, writing to his wife, spoke of Hodson's feat as more resembling "a chapter from the life of Bayard or Amadis de Gaul than the doings of a subaltern of the nineteenth century."

It was at Karnâl that Hodson met again his young friend Charles Thomason of the Bengal Engineers, who owed to Hodson's exertions his own timely escape from death at the hands of roving sepoy mutineers.

"I shall not easily forget our meeting," writes General Thomason. "We both felt we had much to say to each other. He evidently knew my story, and after his long ride and many hours' fighting he was not one I felt myself justified in inviting to a conversation. We had had no news as to what had occurred at Meerut on May 10 when the Mutiny broke out, and the anxiety of all those present can well be imagined. Poor Hodson was absolutely stormed with questions. 'Do let me have something to eat first,' was what he said; 'I absolutely refuse to answer any questions till I have had something.' He then vanished for his wash and brush up.

"Meanwhile all were interested in his repast, which was ready for him when he reappeared. Not a word did he say when he sat down with myself at his right hand, nor did there pass between us anything beyond a sign of kindly recognition to myself 
until he had completed his meal. The surrounding company eyed him all this time with, we may say, awestruck countenances. This silence was uninterrupted until suddenly he put down his knife and fork and said, 'Now I am ready for you.' And then followed the awful recital of what had occurred at Meerut on the evening of May 10, told as only Hodson could tell it. There we sat round him with open eyes until he had finished, when some one said in an inquiring tone, 'Well ?' as if he had not already heard enough. ' Well,' replied Hodson, ' here we are; the wires cut north, south, east, and west; not a soul can interfere with us, we have the cracking of the nut in our own way, and here we are as 'jolly as a bug in a rug'! This was William Hodson all over. He could not be cheery over the Meerut recital, but the thought that the reversal of that terrible catastrophe lay with the small band then surrounding him, untrammelled with official routine, was too much for his soldier spirit, and found vent in the above expression.

"How he did his part history will tell. He was the life and soul of the whole force then marching down to Delhi. As a scout, if he has ever been equalled, he has never been beaten. The Delhi force knew well what a debt they owed to him.

"I may here remark that I have entered more into detail as regards my own arrival into Karnâl solely with a view to showing what tools Hodson had to deal with. To judge from the writings of some, one would think that he had had at his beck and command the metropolitan police and the Irish constabulary. No one knew better their failings than did William Hodson, and there is no greater marvel 
in British history than the results which he attained with such tools."

What sort of tools Hodson had to work with may be seen from Thomason's own account of his arrival at Karnâl. The 23rd of May found Thomason's little party of fugitives at the village of Naolanah, on the left bank of the canal, about twenty miles from Karnâl.

"In the morning," writes General Thomason, "some four sowars rode into the village. . . . After some parley one of the sowars handed me a letter addressed to myself, but the handwriting of it was unknown to me. So opening it I found it beginning, 'My dear Charlie,' which naturally excited my curiosity a good deal, until I found at the end 'yours affectionately, W. S. R. Hodson.' . . .

"It was to this effect: "I have heard of you, and wish I knew where to catch you; but I have my hands full, and am here, there, and everywhere, and cannot tell where I may be to-morrow; but on receipt of this don't delay a moment, but push on at once to Karnâl, where the "gathering" is to be. You had better put yourself in the hands of the men by whom I am sending this. Promise anything you like, and the chief will see you through with it, but don't delay. I have done the best I can for you, and wish it could be more.'

"I read the letter and looked at the men, and I confess that an inspection of their faces did not reassure me. I suppose they were emissaries of the Intelligence Department, and perhaps constituted a part of the nucleus of the then future famous 'Hodson's Horse.' However, evidently they believed in W. S. R. Hodson, and so did I, and so off we 
started for Karnâl. Arrived at the canal Choki of Phurlak, twelve miles from Karnâl, we came to grief with an accident. I need not enter into the details of this mishap, because I am writing of Hodson and not of myself. Suffice it to say, it resulted in Mrs Tronson breaking a collar and some rib bones, and I remained behind as a rearguard to take her into Karnâl. With me, much against my inclination, remained Hodson's men. In justice to them, I must say that I should have fared badly without them; but in justice also to myself, and to show that my judgment was not altogether at fault, I must mention that Isa Khan, whose camel I rode with him behind me, was afterwards wounded fighting against us at Delhi. He was taken wounded, tried, and hanged. I need not say more about the adventures of this night than that they fully justified my suspicions as to my companions. However, all's well that ends well; and, marvellous to relate, we arrived alive at Karnâl at one o'clock in the morning, and I was glad to hand over Mrs Tronson to Dr Balfour, and I lay down to sleep with my boots as my pillow on a floor of a room in Mr Le Bas' house, where, what with refugees and others, it was not easy to find accommodation for my full length.

"On arvaking next morning I learned that Hodson was not there, he having gone to open communication with Meerut, seventy-five miles off. . . . I think it was the next day that he returned to Karnâl." 1

After reporting to Anson at Umbâla the result of his mission to Meerut, Hodson returned to Karnâl "fairly dead beat" on the morning of the 25th. On the same day Anson himself arrived at Karnâl. His little force at that time consisted of two brigades,

1 MS. Reminiscences by General Thomason. 
while a third brigade, under Colonel Archdale Wilson, had been ordered from Meerut to join him at Bhagpat. On the very next day General Anson was attacked with cholera, which carried him off before daybreak on the morning of May 27. With his last breath he made over the command to Major-General Sir Henry Barnard, who had only just arrived from Umbâla.

Meanwhile Hodson had already begun, with the help of a few good friends, to enlist recruits for the new regiment of irregular horse which he himself had been selected to command. "I am to raise," he writes, " as many men as I please-2000 if I can get them. The worst of it is, the being in a part of the country I do not know, and the necessity of finding men who can be trusted. Mr Montgomery is aiding me wonderfully. He called upon some of my old friends among the sirdars to raise men for me. Shamsher Singh is raising one troop; Tej Singh ditto ; Imam-ud-din ditto ; Mr Montgomery himself one or two ditto. All these will be ready in about three weeks. Kanh Singh Rosah, my old friend who commanded the Sikh cavalry at Chilianwâla, will be here in a day or two. I have asked to remain assistant quartermaster-general attached to the commander-in-chief. This allows me free access to him at any time, and to other people in authority, which gives me power for good. The Intelligence Department is in my line, and I have for this Sir Henry's old friend, the oneeyed maulvi, Rajab Ali, so I shall get the best news in the country. Montgomery has come out very, very strong indeed, and behaved admirably. The native regiments at Peshâwar have been disarmed. As yet the Punjâb is quiet and the 
Irregulars true. The Guides are coming down here by forced marches."

In the midst of more pressing matters, $\mathrm{Mr}$ George Ricketts, as the following letter will show, was to prove a friend in need to the future commandant of Hodson's Horse: "Hodson asked me to get him as many good men as I could,-a squadron, if possible,-and if possible with their own horses under them, or with sufficient money in their pockets to buy them; but on this point, horse or money, he was not very particular, for, as he said, he could always pick up the horses. It was a curious business: there were the old Sikh ghorcharhas ${ }^{1}$ everywhere, and old artillerymen, too. They were looking every way, certain that sooner or later they would take a hand one side or the other, and were just biding their time, and it was hard to get a beginning. . . . After the first start the men began to come in, and I had a pretty good number to select from; and the test of their riding capabilities was to ride my grey mare, a countrybred, from my house verandah to the compound gate and back. She was a jungli [untamed], 14.3, and used to stand like a sheep until she was mounted bare-back, and then the fun used to begin. She used to fly right and left, and bound in the air, and lumbai [plunge] all down the road, and get almost all of them off sooner or later; and we soon found out those who had ridden before, and no others were accepted." 2

The men thus enlisted were sent down in batches to the camp before Delhi, where Hodson, with the

1 Horse Guards of the old Sikh rule.

2 Letter quoted in 'Blackwood's Magazine,' March 1899. 
help of a few subaltems worthy of their dashing leader, speedily drilled them into serviceable form.

In Sir Henry Barnard, "a fine gentlemanly old man, but hardly up to his work," Hodson gained a war'm friend, always ready to further his own efforts for the public good. Another of his friends, Colonel (afterwards Sir Thomas) Seaton, marched into Panipat on the night of May 27 at the head of his regiment, the 60th Native Infantry, whose loyalty was even then deemed more than doubtful. "I don't envy hin," writes Hodson, " his new command; but he is a good man and a brave soldier, and if any man can get them over the mess, he will do it."

The two men had met for the first time the year before at Dagshai, where Seaton was spending a few weeks with his brother Douglas of the 1st Fusiliers. "During this visit," he writes, "I had the good fortune to make the acquaintance of that true and gallant soldier, Major (then Lieutenant) W. S. R. Hodson. I was much struck with his appearance,-his broad, handsome, manly brow; his clear, bright, and keen eye; his light, active, wiry frame; his pleasing smile; his frank and cordial manner, - little dreaming under what terrible circumstances our acquaintance would ripen into friendship." 1

Some days had yet to pass before Barnard's little force could begin its final move against Delhi. Meanwhile Hodson was working away with his wonted energy at the various duties which had been intrusted to him. On May 28 he "travelled

1 From Cadet to Colonel. By Major-General Sir T. Seaton, K.C.B. Routledge. 
eighty miles, besides heaps of business. I am tired, I confess, for the heat is awful. The treasuries are empty, and no drafts are to be cashed, so how we are to get money I cannot imagine. I ought to have Rs. 1000 a-month as commandant, and we ought to save half towards paying our debts."

On the 30th Hodson had reached Sumalka in company with the 9th Lancers, Money's troop of Horse Artillery, and the 1st Fusiliers. "This regiment," he writes, "is a credit to any army, and the fellows are in as high spirits and heart, and as plucky and free from croaking, as possible, and really do good to the whole force."

On the last day of May the troops above mentioned were encamped at Larsauli, one march nearer Delhi. Here Brigadier Halifax became so ill that Hodson had to place him in his own shigram (a travelling cart) and see him off towards Umbâla. A few hours later he was lying dead at Karnâl. His death seemed to Hodson only the prelude to many more incidents of a like nature. "Before this business ends, we who are, thank God, still young and strong shall alone be left in camp. All the elderly gentlemen will sink under the fatigue and exposure."

Even in those early days of the great sepoy Mutiny the name of Barnard's chief Intelligence officer was already becoming a tower of strength to our anxious countrymen in Upper India. "Would that we had more like him, and some others I could name," says a correspondent of the "Lahore Chronicle' for June 1, 1857. "Men who can be in the saddle fifteen hours out of the twenty-four at this time of the year form a glorious contrast 
to those who, I hear, are still skulking in safety at Simla and elsewhere in the hills."

It was still fondly hoped that the little force which on the first days of June was assembling at Rai would soon make short work of the mutineers in Delhi. "The Meerut folks," writes Hodson on June 2, "have had another fight with the Delhi mutineers, and again beaten them; but this constant exposure is very trying to Europeans. I wish we were moving nearer Delhi more rapidly, as all now depends on our quickly disposing of this mighty sore. I wish from my heart we had sir Henry Lawrence here-he is the man for the crisis. We are all in high spirits; only eager to get at the villains who have committed atrocities which make the blood run cold but to think of. I trust the retribution will be short, sharp, and decisive."

By June 3 Barnard's headquarters joined the camp at Rai, about twenty miles from Delhi. On the 6th the siege-train, which had narrowly escaped seizure on its march from Philôr, and had been wellnigh stopped by a swollen river, came up with the main body, then halted at Alipur, a march beyond Rai. Next morning Sir Henry's little force was strengthened by the column with which Brigadier Wilson had successfully fought his way from Neerut. By that time the troops assembled under Sir H. Barnard numbered about 4000 men, nearly all British, and all trustworthy.

Hodson learned that some 2000 of the rebels had come out of Delhi " and put themselres in position to bar our road. . . . I think I am more than appreciated by the headquarters' people. I had barely finished the word when I was sent for by 
the general, and had a pretty strong proof of the estimation I am held in. He had been urged to one particular point of attack, and when I went into the tent he immediately turned to the assembled council and said, 'I have always trusted to Hodson's intelligence, and have the greatest confidence in his judgment. I will be guided by what he ean tell me now.' So the eroakers, who had been groaning, were discomfited. This is, of course, for your own eye and ear alone, but it is pleasant, as the general has only known me sinee he has now joined the force."

This, like all his letters of this period, was written to his wife, with whom he corresponded daily. These letters, says the Rev. G. H. Hodson, were "written as best they might, in any moments which he could snatch from the overwhelming press of work, sometimes on the field, sometimes on horseback." They were meant for no other eyes than hers, nor would they ever have been published, adds Mr Hodson, "had my lamented brother been alive, as he had the greatest horror of any of his letters appearing in print." 1

At sunrise of June 8 our little foree moved out from Alipur to attack several thousand rebels strongly posted about Badli Serai. A sharp fight ensued; the serai itself and a battery of six guns were earried at the point of the bayonet, and Hope Grant's cavalry completed the rout. That afternoon the victors eneamped along the ridge overlooking the tall red towers and long walls of the Mughal capital. "Here we are safe and sound," writes Hodson, "after having driven the enemy out

${ }^{1}$ Hodson of Hodson's Horse. 
of their position in the cantonments up to and into the walls of Delhi. I write a line in pencil on the top of a drum to say that I am mercifully untouched, and none the worse for a very hard morning's work. Our loss has been considerable, the rebels having been driven from their guns at the point of the bayonet. Poor Colonel Chester killed at the first fire! Alfred Light (who won the admiration of all) wounded, but not severely. No one else of the staff party killed or wounded; but our general returns will, I fear, tell a sad tale. Greville slightly hurt. The enemy's guns captured, and their dispersion and route very complete."

Of Hodson's own share in that morning's work General Thomason has furnished some characteristic details :-

"The general plan of attack was that the advance column under Sir Hope Grant was to cross the canal by one of the numerous bridges, and following along the right bank of the canal to recross at another bridge, taking the enemy on his left flank. The main body in the mean time was to make a frontal attack.

"As the canal officer best knowing the district," I was told off to accompany and guide Sir Hope Grant. I did not quite know what position the enemy had taken up. I knew that Hodson had been reconnoitring in this direction, so I went to him for information. What he told me seemed to place the enemy's position nearer the Ochterlony Gardens than it turned out to be, and the result was as follows: I led Sir Hope Grant past the

1 At the outbreak of the Mutiny he was acting as deputy-superintendent of the Western Jumna Canal. 
bridge by which we should have recrossed the canal to take the enemy fairly on his left flank. We had so far been completely successful in our turning movement. We were, however, brought up by a watercourse in which our guns seemed to be hopelessly stuck, when the report of the first gun of Badli Serai battle broke the silence immediately upon the left. It might have been the morning gun, but for the unmistakable scream of the round-shot directed against our main column adrancing along the Grand Trunk Road. Then came another shot, which, alas! killed two friends of mine, Colonel Chester, adjutant-general, and Captain Russell, 54th Native Infantry, which had mutinied at Delhi. The few sappers that we had with us were struggling to get the guns across the watercourse, but the sound of the guns did more than even our sappers, hard though they were working. 'Horse Artillery to the front!' was the word of command, and over the guns went. It was at this time that I found Hodson at my right, followed by the 9th Lancers, who were escorting the guns. 'Come along, Charlie, the fun has begun!' Away we started, he on a beautiful chestnut and I upon a poor old artillery caster. We rattled along the right bank of the canal till we came to the first bridge, when Hodson said to me, "Will that bridge carry the guns?' 'Can't say,' was my reply, 'and I have no time to calculate,' and so we crossed and found ourselves in the rear of the enemy's position. We now had to go back on the left of the canal, giving it a wide margin in order to get into action. To do so we had to overcome the obstruction of more than one watercourse. We seemed again 
hopelessly stuck in crossing one of these-the battery, or rather the troop, as we called it in those days, of Turner's Horse Artillery consisting of three 6-pounders and three 9-pounders, the latter being apparently immorable.

Geneste of our corps came up at this crisis, and being well mounted, shouted to the gunners, 'Come along!' and took the watercourse at a jump, and after him went one gun. Seeing the success of Geneste's manœuivre, I thought I would try my old artillery caster, and over he went with another gum behind him. I believe somebody else brought over a third gun in the same way, but who it was I cannot say, but within a few minutes we found ourselves just under the serai with all three of the 6-pounders. A pretty warm berth it was, but it beautifully enfiladed the whole of the enemy's position in their rear. There we remained for some time firing our best, with the Lancers supporting the guns, when up rode Hodson by himself. Within two or three hundred yards of us was a body of the enemy's cavalry, and what Hodson was dying to do was to lead the Lancers against them. No one was more anxious to do so than the officer commanding the Lancers, but his orders were imperative to stick by the guns, and Hodson, disappointed in this, started off towards the canal.

"He had gone a very short distance from us when he found himself confronted by one of the enemy with a shield and tulwar. I shall never forget Hodson's face as he met this man. It was smiles all over. He went round and round the man, who in the centre of the circle was dancing more Indico, doing his best to cut Hodson's reins. 
This went on for a short time, when a neat point from Hodson put an end to the performance, and he himself ranished into space.

"I did not see him again until about two o'clock in the afternoon, when we had occupied the ridge, and I met him coming along from the direction of the Sabzi Mandi. He was a picture, and told me he had had real sport, and, looking towards the Jumna bridge, he said, 'Oh, for another Sobraon!'

"He asked me how I had been getting on, and I told him fairly well, but I was very empty,-we had left camp at 1 A.M.,-whereupon he produced from his holsters a biscuit and gave it to me. It was hard eating, for I was thirsty as well as hungry, and had to go all the way to the Najafgarh Jhil drain to get a drink, and, by the way, nearly lost my life at the hands of the Pandies whilst doing so."

In the shelter of that historic ridge our troops were to lie week after week, like a forlorn-hope, in front of a city held by 30,000 rebels-themselves just able, by dint of heroic efforts and unwearied watchfulness, to hold their ground, amidst every kind of danger and difficulty, against repeated onsets from a determined foe.

Next morning the Guides under Captain (afterwards Sir Henry) Daly arrived in Barnard's camp, thus completing their bot-weather march of 580 miles in twenty-two days. "It would have done your heart good," says Hodson, " to see the welcome they gave me, cheering and shouting and crowding round me like frantic creatures. They seized. my bridle, dress, hands, and feet, and literally threw themselves down before the horse with the tears streaming down their faces. Many officers who 
were present hardly knew what to make of it, and thought the creatures were mobbing me; and so they were, but for joy, not for mischief. All the staff were witnesses of this." Colonel Becher, then quartermaster-general, was heard to declare that the greeting which the Guides gave their old commander was quite enough to stultify all the reports of his umpopularity with that corps. Such a greeting, indeed, must speak for itself to every impartial reader of these pages.

Hardly had Hodson finished his hurried scrawl to the wife he left behind him in the hills, when our troops were suddenly called upon to meet an attack from the mutineers against some of our outposts on the ridge. Hodson himself commanded the troops on the British right. Supporting the advance came the gallant Guides, who followed their old leader with a cheer, and "behaved with their usual pluck." Quintin Battye, who commanded the Guide cavalry, fell mortally wounded while leading his men, said Daly, "like a hero." The whilom leader of the Guides was much affected by the warmth of the reception they had now given him twice in one day. "It has produced a great sensation in camp, and had a good effect on our native troops, insomuch that they are more willing to obey their European officers when they see their own countrymen's enthusiasm."

On this occasion Hodson himself had a narrow escape: "The sabre I thought such a good one went the first blow, and the blade flew out of the handle the second, the handle itself breaking in two. I had to borrow a sword from a Horse Artilleryman for the remainder of the day. The Jhind men with me fought like excellent soldiers. The good general 
[Barnard] came up when it was over and shook hands with each of them."

On the morning of the 11th Hodson aided in "the mournful task of carrying poor Battye to his grave. Poor fellow! he had quite won my heart by his courage and amiable qualities, and it is very, very sad his early death. It was a noble one, however, and worthy of a soldier." Young Battye was the first of several brothers who were destined to give their lives to their country. The brave boy had died in the night, with a smile on his lip and a line from Horace on his tongue- "Dulce et decorum est pro patriầ mori."

The camp had just been excited by the arrival of Colonel T. Seaton and the officers of the 60th Native Infantry. That regiment, in spite of all Seaton's efforts, had mutinied the day before at Rhotak, and their white officers had ridden off for their lives to Barnard's camp, saving nothing but the clothes they stood in. "Seaton is with me," writes Hodson, "looking terribly worn and harassed, but he says quite well in health, though disgusted enough."

Seaton himself had not even a coat to his back when he made his report to Sir Henry Barnard. After breakfasting with his kindly old chief he resolved to look up some of his acquaintances who might help him in his immediate need. He soon found the tent of "that noble officer, my lamented friend Hodson. . . . Fortunately for me, he was within. On seeing me he sprang up, grasped my hand, and cordially congratulated me on my escape from the mutineers, assuring me that he had never expected to see me alive again, he too having heard the report that I had been killed. He invited me to share his 
little tent, and got me a good native charpoy (bedstead.)" 1

On the same day Hodson was requested to consult with Greathed, Chesney, and Maunsell of the Bengal Engineers, on the likeliest mode of carrying Delhi by a sudden assault. These four officers drew up a scheme which met with Barnard's entire approval. Hodson, of course, was greatly pleased at the compliment thus paid him by a general who recognised his worth. "Though I am known," he wrote, "to counsel vigorous measures, it is equally well known I do not urge others to do what I would not be the first to do myself. It is a much more serious business than was at first anticipated. Delhi is a very strong place, and the vast resources which the possession of our arsenal has given the mutineers has made the matter a difficult one to deal with, except by the boldest measures. The city should be carried by a coup-de-main, and that at once, or we may be many weeks before Delhi, instead of within it."

That the plan was a very bold one goes without saying, and Hodson himself appears to have been fully alive to the tremendous hazards involved in carrying it out. But the feeling in camp was strongly in farour of an immediate assault before the rebels had time to augment their numbers and strengthen their defences. Colonel Hope Grant assured Sir H. Barnard that he "thought his determination a very wise one; that every day the rebel forces were increasing, and that the longer we delayed the smaller was our prospect of suecess." ?

1 From Cadet to Colonel.

2 Incidents in the Sepoy War. Blackwood, 1873. 
"That this assault would have been successful," says Sir T. Seaton, "there can be no doubt whatever, and it can as little be doubted that the rebels would have fled before us out of the city. But what if they rallied or offered any considerable resistance? The utmost number of troops we could have thrown into the city would have been 3000 men, who would have been swallowed up in its immensity, and a check anywhere would have been destruction, for we should have had no reserves to fall back on."

Meanwhile about daybreak of June 12 our troops were turning out to repel a sortie from the rebels all along their front. "A sharp fight ensued," says Hodson, "which lasted some four hours. The enemy came on very boldly, and had got close to us, under cover of the trees and gardens, before they were seen. However, the troops turned out sharp, and drove them back quickly from our immediate vicinity : they were then followed up, and got most heartily thrashed. They have never yet been so punished as to-day. I estimate their loss in killed alone at 400 , while our loss was comparatively trifling. The Guides behaved admirably; so did the Fusiliers, as usual. Jacob's wing was the admiration of all: one officer (Captain Knox, 75th) was killed and one or two wounded. I do not know how many European soldiers; but, on the whole, the affair was a very creditable one. I am safe and sound still."

In the dark hours of next morning our troops were silently mustering for the assault, which was to be heralded by an explosion of powder-bags at two of the city gates. In another houl some 1800 men might have won their way inside the rebel stronghold; but, by some unaccountable mischance, the 
pickets needed to strengthen the advancing column had not been withdrawn by the time appointed. Day was already breaking, and with the waning darkness waned every hope of a successful surprise.

Hodson, of course, felt " much annoyed and disappointed at our plan not having been carried out, because I am confident it would have been successful. The rebels were cowed, and perfectly ignorant of any intention of so bold a stroke on our part as an assault: the surprise would have done everything. I am very vexed, though the general is most kind and considerate in trying to soothe my disappointment."

"As a scout Hodson's absolute contempt for anything like danger or even risk," says General Thomason, "was simply unique, and of this we had a fair illustration only a few days after we had occupied our position in front of Delhi. . . . There had been pretty heavy fighting in the Sabzi Mandi during the morning of the 12th, and when we got our orders for the attack, Hodson proposed to some six or eight of us Engineers that we should go out and 'take a look round' when towards sunset it became comparatively cool.

"According to appointment we went, most of us without arms and many without anything on our heads. Hodson led the way, and, chatting merrily, took us straight into the Sabzi Mandi. As we went along the narrow street many of the enemy, with muskets and cross-belts, put their heads over parapets on the houses right and left and bobbed down again. Both Champain, who was to be my assistant field Engineer in the coming attack, and Salkeld looked glum as we advanced 
farther and farther, for neither had brought arms, and the former was glad indeed to get one of a brace of horse-pistols which constitued my armament."

As they approached the Mori Bastion Hodson's attention was drawn to an old woman crossing the road in front of him. With the sweetest of smiles he began questioning her about the various roads in that neighbourhood. At length one of the party, says General Thomason, "suggested to Hodson the place was hardly well chosen for a flirtation, whereupon we deliberately returned to camp by the same road, and not a shot was fired at us the whole evening. . . Salkeld, who won his V.C. and lost his life at the Kashmir gate's final assault, told me that he regarded this reconnoitring trip as the maddest one he had ever made, but I am quite sure Hodson looked upon it as a most ordinary event."

By this time, indeed, it was becoming daily clearer that not half-a-dozen regiments only, but the whole of the great sepoy army of Bengal, had been fired with the mutinous spirit provoked by the new musketry drill, which ordained the biting of cartridges greased with the fat of cows and swine. In spite of later attempts to repair the original mistake, nothing could persuade the bulk of our native soldiers that the British Government had not been plotting to make Christians of them all by means of paper smeared with the fat of animals sacred to the Hindus and unclean to the Mohammedans.

As soon as each fresh body of mutineers arrived in Delhi, it was sent forth to receive its baptism of fire from the besieging army. About 5 P.M. of 
the 13th another of these attacks was led by the 60th Native Infantry. The assailants, writes Hodson, "suffered for it as usual, but also, as usual, we lost several good men whom, God knows, we ean ill spare." He himself "had to run the gantlet now and then of a rain of shot and shells with which the rebels belaboured us. Our artillery officers themselves say that they are outmatched by these raseals in aceuracy and rapidity of fire; and as they have unlimited supply of guns and ammunition from our own greatest arsenal, they are quite beyond us in many respeets. I am just returned from a long ride to look after a party of plunderers from the eity who had gone round our flank: I disposed of a few."

Almost daily the rebels attacked some part of Barnard's position. In Hodson's own words, "We are as nearly besieged as the rebels themselves are, and we lose valuable lives in every encounter." Meanwhile, from the 16th to the 20th, he himself was confined to his tent with a severe inflammatory cold.

"Every one is very kind, the general particularly so: he insists on having me in his own tent, as being so much larger than my own, and he takes the most fatherly eare of me. . . . I woke in the night and found the kind old man by my bedside, covering me earefully up from the draught."

By the 20th Hodson was much better, but still very weak. On the previous evening the rebels had assailed our rear with some 2000 men and six guns. After a sharp fight they were chased back with heavy loss to their own lines by the 9th Laneers and the cavalry of the Guides. Colonel 
Becher, quartermaster - general, was shot through the right arm, and Captain Daly was badly hit through the shoulder. "The consequence is," says Hodson, "that I have in effect to see to the whole work of the quartermaster-general of the army; and in addition the general has begged me as a personal favour to take command of the Guides until Daly has recovered. I at first refused, but the general was most urgent, putting it on the ground that the service was at stake, and none was so fit, \&c., \&c. I do feel that we are bound to do our best just now to put things on a proper footing, and after consulting Seaton and Norman, I accepted the command. ... General Barnard has written most strongly in my favour, and has voluntarily pledged himself to get me my majority as soon as ever I am a captain. I confess I feel a little proud at being earnestly requested to take again the command of which the machinations of my enemies had deprived me."

As early, indeed, as June 16 Sir H. Barnard had requested the adjutant-general to bring to the notice of the new commander-in-chief, Sir Patrick Grant, "the assistance I have received in every way from the services of Lieutenant Hodson, 1st Bengal European Fusiliers. Since the arrival of his regiment at Umbâla up to the present date his untiring energy and perpetual anxicty to assist me in any way in which his services might be found useful have distinguished him throughout, and are now my reasons for bringing this officer thus specially to the notice of the commander-in-chief." 1

1 G. W. Forrest's 'Selections from the Records of the Indian Mutiny,' 1857-58. 


\section{CHAPTER XIV.}

THE SIEGE OF DELHI. JUNE-AUGUST 1857.

By June 21 Hodson had so far recovered that he was able to mount his horse and go about his various duties in spite of the bodily weakness which still annoyed him. "God," he said, " has been very good to me, and in nothing more so than in preserving what is most precious to me from the horrible danger and suffering of so many of our poor countrywomen and children." The sight of so many refugee officers wandering about the camp made him the more thankful that his stepson, Reginald Nitford, then serving at Agra with the 3rd Europeans, "was safe from that at least." Pending the arrival of reinforcements from the Punjâb, he felt that nothing more could be done against Delhi, although, like many others, he still cherished the hope that a few days more might "end this business, . . . and so enable a part at least of the force to move on towards Aligarh, and reopen the roads and dâks, and restore order for the time; but when the end will be who can say?"

On June 23, the centenary of Plassy, the rebels made a furious attack with all their available men and guns along the whole of Barnard's position. All 
day the fight went on under a burning sun, which struck down many of our brave countrymen. A prophecy was current among the sepoys that on this day they were destined to overthrow the Faranghi rule. Hodson, of course, was in the saddle nearly all day. His kind old commander, Colonel Welchman, "got an ugly wound in the arm, and Dennis was knocked down by the sun, and numbers of the men; but nothing less than a knock - down blow from sun, sword, or bullet stops a British soldier. How well they fought to-day, and, to do them justice, so did my old Guides and my new Sikhs, while the little Gurkhas vied with any in endurance and courage."

On the following day Colonel Nerille Chamberlain, ${ }^{1}$ the new adjutant-general, arrived in camp, having made over to Colonel John Nicholson the command of that movable column which had already been doing good work in the Punjâb. His presence, said Hodson, "ought to be worth a thousand men to us." To Sir T. Seaton he was "the right man in the right place, for he always advocated in war bold and energetic measures."

The great sortie on June 23 might have gone ill with our brave soldiers but for the fact that some of Hodson's native spies had brought him timely warning of the enemy's intended movement. About that time his friend Colonel Seaton, who had also come under the doctor's hands, had daily opportunities of watching the working of the Intelligence Department. "Spies came in from the city at all times during the day, and in all sorts of disguises, some bearing intelligence by word of mouth, others bring-

1 Now Field-Marshal Sir Neville Chamberlain, G.C.B., \&c. 
ing mysterious little scrolls that had been coneealed in the most inexplicable manner. These were mostly from Rajab Ali's own connections and friends about Court, and some friendly news-writers whose services he had engaged."

It is needless here to dwell on the dangers to which our spies were exposed alike from their own countrymen and the British sentries. Some of them disappeared, says Sir T. Seaton, "but our newswriters escaped detection. I have two of these letters now before me, little scrolls of the finest paper-finer and closer than our tissue paper-two and a quarter inches long by one and a half broad. ... The translation of one scroll fills two and a quarter pages of large blue letter-paper."

Those spies who brought in verbal intelligence had to undergo a rigorous examination both from Hodson and Rajab Ali. After these two had laid their heads together, Hodson himself would put the messenger through a still more searching examination, in order, as Seaton remarks, to separate the corn from the chaff,- - a very necessary process, for however desirous a native may be. to tell the truth, and even where it is his interest to do so, he eannot help embellishing it a little, like the man regarding whom an Irish friend quaintly said, 'Bedad, colonel, the lad tells too much truth.'. . Hodson's aptitude for turning a native inside out and getting at the truth was first-rate. Such a marvellous eapacity required a complete mastery of the language, a thorough appreciation of the native character, and power to seize at once the peculiarities of the individual under examination." 1

\footnotetext{
1 From Cadet to Colonel.
} 
To Hodson's peculiar merits as a leader of irregular horse Brigadier (afterwards Sir J.) Hope Grant, G.C.B., himself a successful leader of cavalry, paid the following tribute in his diary of the siege: "After Major Daly had been badly wounded Hodson was replaced in command. He was a dashing, clear-headed, energetic officer; no man understood or could lead an irregular regiment better, and at such a time his services in the field could not be dispensed with." 1

"He is scarcely out of the saddle day or night," wrote another officer; "for not only has he to lead lis regiment and keep the country clear, but being Intelligence officer he is always on the move to gain news of the progress of affairs and acts and intentions of the enemy.

"Even when he might take rest he will not, but will go and help work at the batteries, and expose himself constantly, in order to relieve some fainting gunner or wounded man."

When the stress of work in camp fell so hard upon our wearied soldiers that the officers had to dispense with the customary salute, "it was remarked," said another officer, " that Hodson never passed down the lines without every man rendering to him that mark of respect. The soldiers loved him as their own. 'There goes that 'ere Hodson,' said a drunken soldier, as he cantered down the lines; 'he's sure to be in everything: he'll get shot, I know he will, and I'd a deal rather be shot myself: we can't do without him.' "

On June 28 Hodson was despatched to Bhagpat on the Jumna, twenty-five miles from camp, to look after matters there, and try to save the boats which

1 Incidents in the Sepoy War. 
had just been abandoned by a panic-stricken officer from the Meerut garrison. He recovered the boats, and "found all quiet in spite of - 's disgraceful flight." On the night of the 29th he rode off again to Bhagpat, accompanied by Shebbeare of the Guides. "We worked like a couple of 'navvies,' passing the two days and one night on the banks of the river without shelter, and almost without food; for we had nothing but a couple of chupatties each, and a small tin of soup and a little tea, which I fortunately took with me."

By the night of July 1 they succeeded in bringing every boat safe into camp. In sending Hodson forth upon the mission thus successfully accomplished, General Barnard had declared that he did so "because I can trust your judgment quite as much as your energy." 1

In the first weeks of July the flow of reinforcements from the Punjâb had raised the effective strength of Barnard's little army to about 6600 men of all arms. Several hundred recruits for Hodson's new regiment were to reach him a few days later from Lahore and Jagraon. Some of his officers were already in camp-amongst them his second in command, Lieutenant Charles M'Dowell of the 2nd Bengal Fusiliers. "He is a gentleman," wrote Hodson, "and only wants opportunity to become a gallant soldier." M'Dowell had a lively wit, a sunny sensitive nature, and a great soul encased in a small frail-looking body. Himself a soldier's son, he had already seen hard fighting at Chilianwâla and Gujarât, and had since come to know and appreciate his future friend and leader.

1 Hodson of Hodson's Horse. 
Another of Hodson's earliest officers, Captain George Ward of the 8th Bengal Cavalry, had served and fought throughout the two campaigns against the Sikhs. Lieutenant D. W. Wise of the 4 th Bengal Lancers had also served throughout the fierce campaign along the Satlaj.

On the evening of July 3 Hodson informed his chief that a large body of rebels had marched past our right flank along the road to Alipur. At 2.30 A.M. of the 4 th a force of all arms, led by the gallant Major Coke, marched out from camp to intercept them on their return to Delhi. While Lieutenant Roberts ${ }^{1}$ felt for the enemy along the main road, Hodson led his Guides along the right bank of the canal. As soon as our guns had driven the enemy from their positions, the cavalry of the Guides, says Sir Henry Barnard, "followed them with the greatest spirit, and succeeded in cutting up some more" of their number. Twice again during that day the rebels came down upon our wearied troops, who had to fight over ground which the recent rain had turned into a mere swamp. "Both men and horses," writes Hodson, "were terribly knocked up towards the end of the day, and could hardly crawl back to camp; and no wonder. I was mercifully preserved, though I am sorry to say my gallant Feroza was badly wounded twice with sabre-cuts, and part of his bridle cut through, and a piece of my glove shaved off; so it was rather close work. My men, who were the most engaged of all, escaped with the loss of one killed and six wounded, and six horses put horsde-combat."

1 Now Field-Marshal Lord Roberts, V.C., G.C.B., \&c. 
During the afternoon of July 5 Sir H. Barnard breathed his last after a few hours' illness. "Cholera then, as ever, was present in the camp," writes Major (now Sir Henry) Norman, "and the death of any one excited no surprise; but no doubt Sir Henry Barnard's attack was due in a great degree to his unsparing exposure of himself to the sum at all hours of the day, and to great mental anxiety." He was "greatly regretted by the whole force, and most so by those who knew him best. Brave, kind-hearted, and hospitable, it is doubtful if he had an enemy." 1

Hodson himself was naturally "much grieved, for no kinder or more considerate or more gentlemanly man ever lived. I am so sorry for his son, a fine brave fellow, whose attention to his father won the love of us all. It was quite beautiful to see them together." "Poor MrDowell," he adds, "is down with fever-a sad loss just now to "Hodson's Horse,' as they call my growing corps."

On the 8th Hodson and his Guides were out again with a force commanded by Brigadier Longfield, whose sappers blew up some bridges, and an aqueduct over the Najafgarh Canal, about eight miles from Delhi, thus cutting the rebels off from the shortest road to our rear, and from one source of Delhi's water-supply.

On the morning of the 9 th a brisk cannonade from the city and the suburbs was followed by the sudden rush of a hundred rebel horsemen upon a picket of Carabineers and Horse Artillery posted to the right of the Mound Battery. Mistaken at first for some of our own Irregulars, they dashed through the 
pickets right into our camp before the mistake had been discovered. In those few moments of panic and confusion nothing but the cool courage of some of our officers and men, aided by the heroic loyalty of a troop of native horse artillery, ${ }^{1}$ could have saved our arms from untold disaster. Half an hour later the discomfited raiders were hastening back to their old lines, leaving thirty-five of their number dead in the British camp.

It was here that Hodson, "certainly the most wide-awake soldier in the camp," as Hervey Greathed wrote of him, found himself for once entirely taken in by the retreating foe. As Hope Grant's cavalry were following up the pursuit they saw a body of sowar's leisurely taking the same direction as themselves. "They were dressed," says Hope Grant, "exactly like our own men, and I could not believe them to be a hostile force; but to make quite sure I sent my aide-de-camp, Augustus Anson, to ascertain their identity, and he brought me back word that they were a detachment of our own cavalry. Captain Hodson also rode up, accosted them, and marched with them for some distance under the impression that they belonged to one of the Hindustani regiments in camp. They entered into most friendly conversation with him, and told him, I think, that they were a party of the 9 th Irregulars. All of a sudden, however, they put spurs to their horses, galloped off like wildfire, giving us the slip completely; and we then dis-

1 The rebel raiders called upon these brave men to join their side: their only answer was to request Major Olphert's gunners to fire through them into the enemy. 
covered for the first time that they were some rebel cavalry." 1

There was much laughter that night at the headquarters mess over this unlucky mistake-laughter in which Hodson himself would certainly have joined, for he was still what Napier had described him in his first campaign with the Guides.

"Affairs at times looked very queer," wrote a distinguished officer, "from the frightful expenditure of life. Hodson's face was then like sunshine breaking through the dark clouds of despondency and gloom that would settle down occasionally on all but a few brave hearts, England's worthiest sons, who were determined to conquer."

It was about this time that Colonel Seaton returned to camp after thirty-six hours of outpost duty under a pouring rain. "On getting into camp," he writes, "I found my own tent pitched, my servants all waiting, clean clothes, washing tackle, a clean breakfast-table, a nice breakfast, and Hodson with a smiling face, waiting my arrival, and enjoying our new mansion." 2

"You know," wrote Seaton afterwards to a friend, "that during the whole of the terrible siege of Delhi we lived together in the same tent, and excepting while on duty, we were never separate. It was there I saw in all their splendour his noble soldierly qualities; never fatigued, never downcast, always cool and calm, with a cheerful countenance and a word of encouragement for every one. I used often to say, "Here, Hodson, is somebody else coming for comfort.'

${ }^{1}$ Incidents of the Sepoy War.

${ }^{2}$ From Cadet to Colonel. 
Recruits for Hodson's Horse were now coming in faster and in greater numbers. "For officers," he writes, "I hope to have permanently M'Dowell, Shebbeare (now acting as my second in command of the Guides, and a most excellent officer), and Hugh Gough of the 3rd Cavalry. . . . I have seven officers attached to the Guides, but two are wounded, and Chalmers is very ill. Young Ellis of the 1st Fusiliers is down with cholera, poor boy."

On the morning of July 14 some 10,000 of the rebels made a series of determined rushes against our right flank. As our fire from the ridge failed to drive them off, a column under Brigadier Showers moved out at 3 P.M. , and after a hot fight among gardens and walled enclosures forced the enemy to withdraw their guns and shelter themselves within the city. Hodson himself, who had just returned from a long day's work with his cavalry in rear of the camp, joined Shebbeare's party of Guides in time to play a conspicnous part in what he described as "one of the sharpest enoounters we have yet had." "Shebbeare," he adds, "got wounded early in the fight, so I led the Guide infantry myself in the skirmish of the villages and suburbs. I charged the guns with some eight horsemen, a party of the Guide infantry, and 1st Fusiliers. We got within thirty yards, but the enemy's grape was too much for our small party. Three of my officers, Shebbeare, Hawes, and De Brett, slightly wounded, and several men; but though well to the front, my party suffered proportionally least.

"Of the Fusiliers who were with us some sixty men were wounded; Daniell's arm broken by a shot, Jacob's horse shot dead under him, Chamberlain shot 
through the arm, little Roberts wounded, and several more. Everybody wonders I was not hit-none more than myself. God has been very merciful to me."

While the Fusiliers and Coke's Punjâbis were driving the mass of the enemy "helter-skelter through the gardens to our right, I went," says Hodson, "with the Guides, Gurkhas, and part of the Fusiliers along the Grand Trunk Road leading right into the gates of Delhi. We were exposed to a heary fire of grape from the walls, and musketry from behind trees and rocks; but pushing on, we drove them right up to the very walls, and then were ordered to retire."

Emboldened by the rearward movement of our troops, the enemy rallied and brought two of their guns to bear on their late assailants. Hodson, however, was covering the retreat. With the help of a few officers and men hastily got together he prepared to stem the onset of a body of rebel horse. He called upon his men to fire into the advancing cavalry. "I got a few men to open fire," he wrote. "My gallant Guides stood their ground like men; Shebbeare, Jacob, Greville, and little Butler came to the front, and the mass of the enemy's cavalry, just as I said, stopped, reeled, turned, and fled in confusion."

For a moment the guns behind them were deserted, and Hodson "tried hard to get up a charge to capture them: we were within thirty paces; twenty-five resolute men would have been enough; but the soldiers were blown and could not push on in the face of such odds, unsupported as we were, for the whole of the rest of the troops had retired. My eight horsemen stood their ground, and 
the little knot of officers used every exertion to aid us, when suddenly two rascals rushed forward with lighted portfires in their hands, fired the guns, loaded with grape, in our faces, and when the smoke cleared away, we found to our infinite disgust and chagrin that they had limbered up the guns and were off at a gallop. We had then to effect our retreat to rejoin the column under a heavy fire of grape and musketry, and many men and officers were hit in doing it. I managed to get the Guides to retire quietly, fighting as they went, and fairly checking the enemy, on which I galloped back and brought up two guns, when we soon stopped all opposition and drove the last Pandy into Delhi.

"My Guides stood firm and, as well as my new men, behaved admirably: not so all who were engaged, and it was in consequence of that poor Chamberlain got wounded; for seeing a hesitation among the troops he led, who did not like the look of a wall lined with Pandies, and stopped short instead of going up to it, he leaped his horse clean over the wall in to the midst of them, and dared the men to follow, which they did, but he got a ball in the shoulder. There is not a braver heart or cooler head in camp." 1

In that day's fighting Hodson seemed as usual to bear a charmed life. Writing to his wife a few days later, he confirms the story of a hair-breadth escape which had just appeared in a Simla newspaper. "The story in the papers about the boot was essentially correct for once, though how they should have

1 "A charge of cavalry was turned by a few musket-shots from a party under Hodson, who always turns up in moments of difficulty." -Greathed's 'Letter's written during the Siege of Delhi.' 
got hold of it I do not know, for I never mentioned it even to you, since it certainly could not be called a wound, though a very narrow escape from one. A rascally Pandy made a thrust at my horse, which I parried, when he seized his tulwar in both hands, bringing it down like a sledge-hammer : it caught on the iron of my antigropelos legging, which it broke into the skin, cut through the stirrup-leather, and took a slice off my boot and stocking; and yet, wonderful to say, the sword did not penetrate the skin. Both my horse and myself were staggered by the force of the blow, but I recorered myself quickly, and I don't think that Pandy will ever raise his tulwar again. I should not liave entered into all these details about self but for those tiresome papers having made so much of it."

On the 16th Hodson took leave of Colonel Welchman, who was sent off on the following day towards Umbâla and the hills. "We are in a nice fix here," writes Hodson. "General Reed is so ill he is ordered away at once; Chamberlain is on his back for six weeks at least; Norman, however, is safe and doing admirably, - were he to be hit, the 'headquarters' would break down altogether. There will be no assault on Delhi yet; our rulers will now less than ever decide on a bold course; and, truth to tell, the numbers of the enemy have so rapidly increased, and ours have been so little replenished in proportion, and our losses, for a small army, have been so severe, that it becomes a question whether now we have numbers sufficient to risk an assault. Would to Heaven it had been tried when I first pressed it!"

On the 17th Major-General Reed, who had so 
lately stepped into Barnard's place, was compelled by failing health to go up to Simla on sick-leave. Before starting he made over his command to Colonel Wilson of the Bengal Artillery, who, not being the senior officer in camp, was promoted by Reed to the rank of major-general. Chamberlain's wound alone disabled him from taking up the command, to which his past services and present standing would have justly entitled him. ${ }^{1}$

On the afternoon of the 18th Hodson was summoned "to take the Guide cavalry down into the suburbs to support some guns, and assist in driving the enemy back into the city. My own men, whose duty was the difficult one of enduring a very hot fire without acting, behaved admirably, and I had the satisfaction of losing only one killed and two wounded, besides a few horses, who generally come off second best where bullets are flying about. My poor Feroza was hit by one, but not dangerously, and I was again most mercifully preserved unharmed."

From this time there was no more serious fighting in the Sabzi Mandi, for our engineers had at last succeeded in clearing away the old serais, walls, and gardens for some distance round the posts held by our pickets in that suburb, while the breastworks connecting these pickets with the crest of the Hindu Rao post on the ridge were also completed and made secure. ${ }^{2}$

When the earliest tidings of the Cawnpore massacres reached camp on the 19th, the consequent

${ }^{1}$ Norman's Narrative. The Chaplain's Narrative of the Siege of Delhi.

${ }^{2}$ Norman's Narrative. 
depression of spirits among our men brought on a fresh outburst of cholera. In order to cheer up his men General Wilson directed that a regimental band should play every morning in the centre of the camp. "This," says Sir T. Seaton, "had a very beneficial effect. The men of different regiments met together and had an hour's pleasant chat, which brightened them up, and was far better for them than sitting in their tents, gloomy and dull, blessing (?) the heat, the flies, and the Pandies, an occupation that was a certain shoeing-horn for cholera."

On the 20th, as Colonel Seaton was returning from a reconnaissance in the Sabzi Mandi, a small body of rebels suddenly began to fire upon his retreating troops. They were even threatening a rush upon his rear, when "the Guides, admirably posted by that excellent officer Lieutenant Hodson, gave them a volley with a cheer, which drove them off precipitately, and I returned to camp without further molestation." 1

On July 23rd, while a column under Brigadier Showers was engaged in driving the enemy back from Ludlow Castle, Colonel Seaton was badly wounded by a musket-ball, which entered the breast and came out at the back, breaking one of his ribs, and thereby causing some injury to one of his lungs. On sceing the condition of his wounded friend, Hodson galloped off at once to camp and got everything ready, including Dr Mactier, for ministering to the sufferer's needs. "Dr Mactier," says Seaton, "told Hodson that I was not on any account to speak or to be spoken to for a week, as my recovery

${ }^{1} \mathrm{G}$. W. Forrest's Selections. 
depended on perfect silence.... I owe as much to Dr Mactier's skill, patience, and kindness as any wounded man ever owed to any doctor."

How much he owed to Hodson's tender nursing was a thing which he could never forget. "He watched and tended me with the affection of a brother; he anticipated all my wants, prevented me from speaking, and carefully excluded every one from the tent." "You know," wrote Seaton, long after Hodson's death, "how he nursed me when I was wounded. I am indebted for my rapid recovery in a very great measure to his care and forethought; and it was whilst lying helpless and feeble I saw that the brave and stern soldier had also the tenderness of a woman in his noble heart. His constant care was to prevent Mrs Hodson from feeling any anxiety that he could save her; so that whenever he went out on any expedition that would detain him beyond twenty-four hours, he invariably asked me, and I used to make it my duty, to write to Mrs Hodson daily, accounting for his absence, and giving such details as I could of his doings."

About this time Hodson consented, at General Wilson's suggestion, to give up the command of the Guides and retain the post of assistant quartermaster-general. He had already found himself overtaxed with too many duties. He would have preferred to lead his old corps into Delhi-" "but it is best as it is. . . The general was very complimentary on my doings while commanding the Guides, and 'trusted to receive equally invaluable services from my new regiment.'"

Before the end of July the adjutancy of his new regiment had been conferred upon Lieutenant now 
General Sir Hugh) Gough, G.C.B. and V.C., in room of Lieutenant M'Dowell, who had hitherto been acting both as adjutant and second in command. Gough was at Meerut when he received the welcome news of his appointment to a corps commanded by a "man whose name had been well known in the Punjâb and frontier campaigns as a sabreur of distinction, the very mention of whom was a proverb and war-cry in the Punjâb as "The Great Hodson." " 1

On reaching the camp before Delhi Gough at once reported himself to his new commandant. He found Hodson sitting booted and spurred, talking to one of his native spies from Delhi. "He looked up with a quick sharp glance, which seemed to go through me,- as he told me afterwards, he 'liked my looks,'-and then said, 'You are just the man I want, Gough; are you fit for a ride?' I promptly said, 'Yes, sir' (though, as a matter' of fact, I was rather beat); and he then said, "Well, come along with me; I am going out for a reconnaissance.'

"I had some breakfast, and we started with a small body of his men, and had a really long ride and a good reconnaissance through the enemy's country. We had no adventures, but I was struck with Hodson's marrellous knowledge of the language and the quick way he seemed to extract all the information he wanted, and his great powers of endurance."

Late that night they returned to camp, after a ride of more than sixty miles. Gough was " glad to be regaled with a good dinner, the best curry-andrice I ever tasted, and a bottle of becr. Although

${ }^{1}$ Sir Hugh Gough's Old Memories. 
Hodson was able to work everlastingly on very little when necessary, at other times he took very good care of the inner man. He seemed much pleased with me during the day, and I slept that night very tired and very happy."

"Since the 23rd hardly a shot has been fired here," says Hodson, writing on the 27 th. "The news-letters from the city mention meetings in the market-place and talkings at the corners of the streets, with big words of what they intend to do; but they (the people) are actually cowed and dispirited, while their rulers issue orders which are never obeyed."

While regretting the absence of any leader with a head to devise or a heart to dare some bold forward movement against Delhi, he admits that "it would require both a wise head and a very great heart to run the risk with so reduced a force as we have here now: 2200 Europeans and 1500 native infantry are all that we now can muster."

On the last day of July the Pandies made an attempt on our position; but nothing came of it, except a long day's work in the saddle for Hodson and his men, who had to watch the movements of a rebel column threatening the British rear. "I have just returned," he wrote that evening, "after some hours of the heaviest rain I was ever out in, drenched to the skin, of course, and somewhat tired, so judge what a comfort a dry flannel shirt must be."

In one of her letters to her husband Mrs Hodson had insisted on the difference between doing one's duty and running unnecessary risks. "But what is one's duty?" asks Hodson in return. "Now I 
might, as I have more than once, see things going wrong at a time and place when I might be merely a spectator and not 'on duty,' or ordered to be there, and I might feel that by exposing myself to danger for a time I might rectify matters, and I might therefore think it right to incur that danger; and yet if I were to get hit it would be said, 'He had no business there'; nor should I, as far as the rules of the service go, though in my own mind I should have been satisfied that I was right. These are times when every man should do his best, his utmost, and not say, 'No; though I see I can do good there, yet, as I have not been ordered and am not on duty, I will not do it.' This is not my idea of a soldier's duty, and hitherto the results have proved me right."

From the afternoon of August 1st until late on the following day the mutineers made persistent attacks along the right front and flank of the British lines. "All night long," says Norman, "the roar of musketry and artillery was incessant. Constantly they came close up to our breastworks, but were always repulsed by the fire of our infantry, aided, when practicable, by grape. Our light mortars, too, played with effect upon the masses below the ridge; but it was not till 10 A.M. of the 2 nd that their efforts began to cease, and they did not altogether retire until 4 P.M."

Meanwhile the heavy rains which had frustrated the enemy's attempts to cut off a British convoy on July 31 were also working a sensible improvement in the health of our troops. By August 3 no fresh case of cholera had been reported in the last four 
days, and our men, says Seaton, "were more cheerful and hopeful." 1

Sickness, however, in other forms was still prevalent. "We have been nearly losing another general," says Hodson. "General Wilson was very ill for a few days, but is now better. He is older, however, by ten years than he was. I like him very much, but the responsibility and anxiety of what is certainly a very difficult position have been too much for him, and he has got into the way of being nervous and alarmed, and over-anxious even about trifles, which shakes one's dependence on his judgment. These men are personally as brave as lions, but they have not big hearts or heads enough for circumstances of serious responsibility. This word is the bugbear which hampers all our proceedings. Would we could have had Sir Henry Lawrence as our leader; we should have been in Delhi weeks ago."

It was not known in camp that Hodson's dear old friend and master had perished at Lucknow a month earlier, "trying to do his duty." " "The loss of such a man at this crisis," says the Rev. J. E.

1 From Cadet to Colonel. Chaplain's Narrative. Greathed's Letters.

2 "On the morning of July 2 a shell burst in Sir Henry's room, not so harmlessly as that which burst there the day before. . . . For two days he lingered with a dreadful wound below the hip, still able at times to issue a few last directions, messages, and commands, worthy alike of a thorough soldier and a guileless Christian. ... . On the 4th of July his great soul fled, the soul of one who, in the words he himself had once suggested for his own epitaph, had al ways 'tried to do his duty.' . . . The very soldiers who were about to bear his body to the grave stooped down one after another to kiss his cold forehead, so deep was the universal sorrow for the death of 'a public benefactor and a warm personal friend.' "-Trotter's 'India under Victoria.' 
Rotton, "was universally lamented as a national calamity. He was not only great, but good as he was great; a man who feared God, and eschewed evil, and wrought righteousness." 1

"Who had known him, and not loved him?" wrote another chaplain, the Rev. J. Cave-Browne. "That heart, gentle as a child's, with all its firethat manner so courteous, so winning of confidence -that form, manly though spare-all the traces of character which endeared him to all who worked with him and under him, and which ennobled him in the memory of that country which he served, and for which he died." ${ }^{2}$

1 Chaplain's Narrative.

2 The Punjâb and Delhi in 1857. 


\section{CHAPTER XV.}

BEFORE DELHI. AUGUST-SEPTEMBER 1857.

Or August 4 the news of Havelock's victorious entry into Cawnpore reached the camp before Delhi. The destruction of Sir Hugh Wheeler and his hapless garrison was also fully confirmed; and Havelock, in Hodson's words, "was too late to save the unfortunate women and children, who were massacred in their prison, before his arrival, by their guards. Such fiends as these our arms have never met with in any part of the world. May our vengeance be as speedy as it will unquestionably be sure!"

On the 6th Hodson had hardly returned from one of his reconnaissances when he found himself ordered on another expedition, from which he did not return until three o'clock of the next morning. "Hodson keeps an Argus-eye on the rear and left flank, and is always ready for an adventurous ride. I am not surprised at Gough liking him ; he has a rare gift of brains, as well as of pluck. The uniform of his men, khaki tunics, with a scarlet sash over the shoulder, and turban, is very picturesque." 1

On the morning of August 8 Nicholson rode into

$$
1 \text { Greathed's Letters. }
$$


camp a few days ahead of the movable column, which under his bold and skilful leading had spread dismay and havoc among the mutineers in the Punjâb. To Hodson he is "a host in himself, if he does not go and get knocked over as Chamberlain did." To the whole camp his coming seemed to herald the first step in some daringly decisive movement against the city which our troops had made a show of besieging for two months past.

On the same day Hodson speaks with just disapproval of the new arrangement by which the infantry of the Guides had been widely separated from the cavalry. The Guides, he held, should not be separated, and "should be kept as much apart as may be from other corps." His own regiment, he adds, "is also in the cavalry brigade, and is very hard-worked. It is bad for a young and unformed corps, but there is such a scarcity of cavalry here that I cannot even remonstrate."

$\mathrm{He}$ had already gained "no small amount of kudos" for having so many fit for duty within two months after the order for enlisting them had first been issued. "I shall have two more troops in with the 52nd [Light Infantry], and Nicholson has given me fifty Afghans, just joined him from Peshâwar, which, added to thirty coming with Ali Reza Khan from Lahore, will complete an Afghan troop as a counterpoise to my Punjâbis."

It may interest the reader to learn that the uniform of "Hodson's Horse" consisted of a khaki tunic, a huge scarlet turban, and a scarlet sash worn over the shoulder, which led to their receiving the nickname of " Flamingoes."

Meanwhile the bridge over the Jumna by which 
reinforcements were continually reaching the rebels resisted all our efforts for its destruction. "Our engineers," says Hodson, "have tried their worst, and failed. I have tried all that money could do, to the extent of 6000 rupees, but equally in vain. So there it remains for the benefit of the enemy."

Before dawn of August 12 a column of all arms, led by the gallant Brigadier Showers, completely surprised the enemy's pickets about Ludlow Castle and the Kudsia Bagh. The rebels fought hard but vainly, and in less than half an hour Ludlow Castle was cleared of every living sepoy. Hodson himself came upon the scene before the fight was over, and carried a message from Coke to the brigadier. "I found Showers himself wounded, and then had to find a field officer to take command, after which I assisted generally in drawing off the men-the withdrawal or retirement being the most difficult matter always, and requiring as much steadiness as an attack."

Four of the enemy's guns were brought into camp as trophies of a success somewhat dearly earned by the loss of more than a hundred slain or wounded. "The return to camp," says Hodson, "was a scene worth witnessing, the soldiers bringing home in triumph the guns they had captured, a soldier with musket and bayonet fixed riding each horse, and brave young Owen astride one gun, and dozens clinging to and pushing it, or rather them, along with might and main, and cheering like mad things."

On the morning of the 14th the Punjâb column, 3000 strong, headed by its glorious leader, John 
Nicholson, marched into camp with bands playing, amid ringing cheers from the force it had come to succour in the nick of time.

Among those who then greeted the war-worn heroes of Trimmu Ghât, Hodson was not to find a place. He had been out that morning on a fruitless reconnaissance, and had hardly begun a hurried letter to his wife when he got his orders to start that night for Rohtak, where a party of mutineers from Delhi were said to be planning fresh mischief against our right rear. With 230 of his own horse, 100 of the Guide cavalry, 25 of the Jhind Horse, and only six European officers, he set off on one of the most daring enterprises which he was ever called upon to carry through. At the end of a week he was to reappear, unhurt himself, and happy in the entire success of a hazardous errand, which delighted Wilson and enhanced his own renown as a consummate cavalry leader.

How hazardous an errand he had undertaken, with what skill, hardihood, and prompt resourcefulness he had discharged it, may be gathered, in part at least, from his own letters and his official report. By noon of the 15th his little force had pushed on as far as Kharkauda.

"Having been informed that a number of irregular cavalrymen, whose homes were in the village, had arrived the day before from Delhi at Kharkauda, I took measures for securing the several entrances to it and attempting their capture, sending a small party of the Guide Corps to surprise and arrest the leading man, named Bashârat Ali, a risaldâr of the 1st Regiment, irregular cavalry. Both objects were accomplished, only two sowars having had time to 
effect their escape before the village was surrounded. I then entered the village with a party of dismounted sowars. From information received from the villagers, I was able to seize several of the mutineer sowars before they had time to arm. A large party, however, took refuge in the upper storey of a house belonging to one of the lambardars of the village, and defended themselves desperately. They were eventually overpowered and destroyed, but not without considerable difficulty and several casualties on our side, Lieutenant H. Gough and seven men being wounded. I subsequently caused those of the captured who were proved, on inquiry, to lave been in the service of Government and to have joined the rebels, to be executed." 1

It was on this occasion that Lieutenant Hugh Gough owed his life to his brother Charles, who was then serving with the Guides. Gough himself had climbed by a ladder up to the roof of the house in which a number of mutineers had taken refuge, while some of his party forced their way inside. "When the enemy made their desperate rush," says Sir Hugh Gough, "I was rather in the forefront of the party awaiting them, and in the mêlée which took place I was forced backwards, and, suddenly making a false step from the roof on to a lower roof about a foot down, fell or was forced on my knees. While thus half falling, one man made a cut at me with his heavy sword, which cut right down my riding-boot. Another was aiming a better-directed blow, when my brother, seeing my danger, rushed forward and attacked the two, killing both, and thus undoubtedly saved my life." ${ }^{2}$

${ }^{1}$ Forrest's Selections.

${ }^{2}$ Sir H. Gough's Old Memories. 
On the morning of the 16th Hodson marched on to Bohar, five miles short of Rohtak. Here he had hoped to "harass à la Cosaque a large party of horsemen and foot, with two guns, who have been moving along from Delhi, plundering the wretched villagers en route, and threatening to attack Hansi. They, however, thought discretion the better part of valour, and hearing of our approach, started off at a tangent before we got near enough to stop them.

"We have been drenched with rain, so I am halting to dry and feed both men and horses, and then we go on to Rohtak."

On the morning of the 17th Hodson moved on to Rohtak, the chief ciril station of the district which bears its name. "On reaching Rohtak," he writes to his wife, "we found the Mussulman portion of the people and a crowd of Irregulars drawn up on the walls, while a considerable party were on a mound outside. I had ridden forward with Captain Ward and a few orderlies to see how the land lay, when the rascals fired and ran towards us. I sent word for my cavalry to come up, and rode slowly back myself in order to tempt them out, which had partly the desired effect, and as soon as my leading troop came up, we dashed at them and drove them helter-skelter into the town, killing all we overtook. We then encamped in what was the kutcherry compound, and had a grateful rest and a quiet night. The representatives of the better-disposed part of the population came out to me, and amply provided us with supplies for both man and beast."

But a yet more trying ordeal awaited Hodson and 
his little force. About 7 A.м. of the 18th he learned that Babar Khan had brought into Rohtak a body of 300 Rangar horsemen, who a few minutes later were seen dashing out from the town towards Hodson's camp, followed by some 900 footmen, armed with swords and matchlocks. A small party of Jhind horsemen coming up at that moment to reinforce Hodson were in time to receive and check the brunt of the rebel onset.

Meanwhile Hodson, who had kept his horses ready saddled, lost no time in turning out his men. With twenty of these he charged the assailants, and drove them back in disorder towards the town. "Directly the whole detachment," to quote from his own despatch, "was ready and formed up, I sent what little baggage and followers we had to the rear under a sufficient escort, and prepared for a further attack. I formed the main body on the road in three lines, the Guides in front, sending a troop out to the right front under Lieutenant Wise, and one to the left under Lieutenant M'Dowell, ready to take the enemy in flank, should they again charge up the roads (of which there are three leading from the town to our position). These movements were covered by skirmishers, and by the excellent fire of the Jhind horsemen armed with matchlocks, whom I desired to dismount and drive back by their fire any part of the enemy who might come from under shelter of the buildings. This service they performed exceedingly well and most cheerfully."

Finding that his ammunition was nearly exhausted, and seeing that nothing could be gained by fighting against walls lined with matchlockmen, 
he "determined to draw them out into the open country behind our position, and endeavour to bring on a fight there."

This perilous manœuvre, on which Hodson may be said to have staked his fame as a great military leader, was carried out with brilliant success. It was a manouvre which would have tasked the steadiness of tried reterans, and two-thirds of his men were little better than raw recruits. But Hodson knew that his untrained sowars could be trusted to go wherever the Guides and his English officers might point the way.

"Everything," he says in his despatch, "turned out as I had anticipated. My men withdrew slowly and deliberately by alternate troops (the troop nearest the enemy by alternate ranks) along the line of the Bohar road, by which we had reached Rohtak, our left extending towards the main road to Delhi. The Jhind horsemen protected our right, and a troop of my own regiment the left. The enemy moved out the instant we withdrew, following us in great numbers, yelling and shouting and keeping up a heavy fire of matchlocks.

"Their horsemen were principally on their right, and a party galloping up the main road threatened our left flank. I continued to retire until we got into open and comparatively dry ground, and then turned and charged the mass who had come to within from 150 to 200 yards of us.

"The Guides, who were nearest to them, were upon them in an instant, closely followed by, and soon intermixed with, my own men.

"The enemy stood for a few seconds, turned, and then were driven back in utter confusion to the 
very walls of the town, it being with some difficulty that the officers could prevent their men entering the town with the fugitives. Fifty of the enemy, all horsemen, were killed on the ground, and many must have been wounded."

"Nothing," he adds, "could be better than the conduct of all concerned. The Guide Cavalry behaved with their usual dashing gallantry, and their example was well emulated by the men of my new regiment, now for the first time engaged with an enemy. They not only remained under fire unflinchingly, but retired before the enemy steadily and deliberately, and when ordered, turned and charged home boldly. It would have been hopeless to expect this but for the magnificent leading and admirable management of the officers in command of the several troops - Captain Ward and Lieutenants $\mathrm{M}^{\circ}$ Dowell, Wise, C. J. Gough, and H. Gough. The difficulty of their task will be appreciated when it is remembered that, with the exception of the Guides, none of the party had been drilled or formed or knew anything of field movements."

That night the rebels clcared out of Rohtak and took refuge in the neighbouring villages. On the 19th Hodson halted at a village on the north side of Rohtak to take in supplies, and to receive a reinforcement of eighty well-equipped horsemen from Jhind, "whom my good friend the Rajah sent as soon as he heard I was coming Rohtakwards. So I have now 400 horsemen, more or less, fresh ammunition having come in this morning, and am quite independent."

Meanwhile a rumour had reached Wilson's camp that Hodson had been driven by superior numbers 
to take refuge within the walls of the jail at Rohtak. The consequent alarm was not shared by the Ciril Commissioner, Hervey Greathed. "I have such confidence," he wrote, "in Hodson's audacity and resource, and it turned out he was skirmishing with the enemy between the jail and another building.

"In the evening a letter came from him describing his position. He had seduced the enemy out into a plain, and then driven them back pell-mell: he then withdrew on the Gohanah road, in the direction of Jhind, and was in communication with the Jhind authorities." 1

With reference to the rumour mentioned above, Hodson "cannot sufficiently condemn the idle tongues and foolish brains that concocted such absurd stories about me in the Rohtak business. We were never in any extremity whatever, nor did I ever feel the slightest anxiety, or cease to feel that I was master of the situation. Danger there must always be in war, but none of our own creating, as the fools and fearful said, ever existed."

On the evening of the 19th he received Wilson's order recalling him to the camp before Delhi. Marching leisurely back, he reached Sonpat on the 21st. On the evening of the 22nd he got a note from General Wilson "desiring me to look out for and destroy the 10th Light Cavalry mutineers from Firozpur. He authorised my proceeding to Jhind, but without going through the Rohtak district. Now, as to do this would involve an immense detour, and ensure my being too late, and consequently having a long and fatiguing march for my

${ }^{1}$ Greathed's Letters. 
pains, I wrote back to explain this, and requested more definite instructions. He must either say distinctly 'do this or that,' and I will do it; or he must give me carte blanche to do what he wants in the most practicable way, of which I, knowing the country, can best judge. I am not going to fag my men and horses to death, and then be told I have exceeded my instructions. He gives me immense credit for what I have done, but 'almost wishes I had not ventured so far.' The old gentleman means well, but does not understand either the country or the position I was in, nor does he appreciate a tenth part of the effects which our bold stroke at Rohtak, forty-five miles from camp, has produced. N'importe, they will find it out sooner or later. I hear both Chamberlain and Nicholson took my view of the case, and supported me warmly."

Meanwhile Charles Thomason was proceeding on duty along the Grand Trunk road "very, very down at the sad news" of the supposed disaster at Rohtak, "when, looking up, I saw some native cavalry coming along the road towards me. I was not at all sure who they were, but went on my way until we met, when, to my delight, I recognised Hodson and M'Dowell chatting jovially together at the head of 'Hodson's Horse.' Mutual salutations followed, something in this fashion: 'Hulloa, William, is that you? I just heard before leaving camp that you and all your men had been annihilated at Rohtak.'

"'Not a bit of it, Charlie,' was the reply; 'you don't catch a weasel asleep, and here, as you see, we are, as merry as grigs. Fact is, Mac and I have 
been playing at William the Conqueror and the battle of Hastings, - and then he told me of the whole fight, now a brilliant page of English history."

On the 24th Hodson arrived in camp, "looking," says Greathed, "as fresh as possible." In this case, however, appearances were deceitful, as the following letter to his wife will show:-

"I returned here this morning very tired and unwell, and not able to write much, for I have been obliged to have recourse to the doctor. I an to have a surgeon attached to my regiment at once, as I represented how cruel it was to send us out on an expedition without a doctor or a grain of medicine. We had eight wounded men, and two officers had fever on the road, and nothing but the most primitive means of relieving them. . . .

"Nicholson has just gone out to look after a party of the eneny with twelve guns, who had moved out yesterday towards Najafgarh, threatening to get into our rear. I wanted to have gone with him; but I was laughingly told to stay at home and nurse myself, and let some one else have a chance of doing good service. This was too bad, especially as Nicholson wished me to go."

Hodson's services on this occasion were warmly acknowledged by General Wilson :-

"Lieutenant Hodson most fully carried out my instructions to my entire satisfaction, and his report will show that the whole of his detachment, both officers and men, behaved throughout in the most gallant and effectual manner.

"It must have been most gratifying to Lieutenant Hodson to find his new regiment so steady 
and staunch in their first engagement with the enemy." 1

To one incident in that memorable ride to Rohtak especial reference must be made, because it supplied a handle for one of those calumnies which pursued Hodson's memory long after his death. Among the prisoners taken at Kharkauda was one Bisharat Ali, a risaldar, or troop commander, of the 1st Irregular Cavalry. This man having been caught, as it were, red-handed in a village full of armed mutineers, was summarily tried and shot. His execution under such conditions excited no surprise or comment in Wilson's camp. "As there was no doubt of his disloyalty, rendered more open and declared by the resistance of his men, who were all of his own regiment, Hodson was quite justified in his action, and the native officer and those with him fully deserved their fate." 2

It is true that Bisharat Ali had lately been decorated with the Order of Merit by Norman's own hands, and that Major (now General) Crawford Chamberlain held strong convictions in favour of his innocence; but it was a time when the bestgrounded belief and the strongest certificates of sepoy loyalty were apt to be wholly stultified by patent facts.

The Rev. G. H. Hodson tells us that Risaldâr Isri Singh of the 19th Bengal Lancers, who had come to England for the Queen's Jubilee in 1887, made the following statement to a general officer with whom he had long been acquainted: "That he lived when young in or near Bisharat Ali's village, and remembered him well, and how he

1 Forrest's Selections.

2 Gough's Memories. 
used to boast that he could make the Sahib-log believe what he chose; that it was notorious that he was a very dangerous character, disseminating rebel doctrines, and preparing to take a leading part in the event of the rebellion succeeding, while keeping ostensibly on good terms with the authorities, and hoodwinking them. Isri Singh had never heard Major Hodson's conduct in shooting him called in question."

"The same officer had been told previously by a native officer of Hodson's Horse, who was present on the occasion, that no one doubted the guilt of the condemned man, and all considered his death a mere act of justice."

It is also true that Bisharat Ali had once stood Hodson's security for a loan from his regimental bank. This loan, however, had long since been repaid, and Hodson was certainly not the man to let past obligations stand in the way of his imperative duty towards a convicted mutincer. As the writer in 'Blackwood' justly remarks, "He was found in the midst of a hotbed of rebels, with whom he was evidently on friendly terms, or he could not have remained there alive; and that too not within a few days or weeks of the outbreak of the Mutiny, but at the end of August, long before which time every soldier who was loyal to the British Government had been summoned to rejoin his regiment. Under these circumstances, and at such a time, any officer who did his duty would have acted as Hodson did." 1

Moreover, at such a crisis no half measures were really possible. Hodson, in truth, had no alterna1 'Blackwood's Magazine' for March 1899. 
tive between dooming his prisoner to instant death and setting him free to plot further mischief against the Government whose salt he had eaten.

In connection with Hodson's work at this period the following letter from an officer who served at Delhi may fitly be introduced :-

"The way Hodson used to work was quite miraculous. He was a slighter man and lighter weight than I am. Then he had that most valuable gift of being able to get refreshing sleep on horseback. I have been out with him all night following and watching the enemy, when he has gone off dead asleep, waking up after an hour as fresh as a lark; whereas, if I went to sleep in the saddle, the odds were I fell off on my nose.

"He was the very perfection of a 'free-lance,' and such an Intelligence officer! He used to know what the rebels had for dinner in Delhi.

"In a fight he was glorious. If there was only a good hard scrimmage he was as happy as a king. A beautiful swordsman, he never failed to kill his man; and the way he used to play with the most brave and furious of these rebels was perfect. I fancy I see him now, smiling, laughing, parrying most fearful blows as calmly as if he were brushing off flies, calling out all the time, "Why, try again now'; 'What's that?' 'Do you call yourself a swordsman?' \&c.

"The way that in a pursuit he used to manage his hog-spear was miraculous. It always seemed to me that he bore a charmed life, and so the enemy thought.

"His judgment was as great as his courage, and 
the heavier the fire or the greater the difficulty, the more calm and reflecting he became." 1

While Hodson was chafing in his tent under the illness which forbade his taking part in Nicholson's famous march against a large body of rebels eager to intercept a siege-train on its way down from Umbâla, the one great leader under whom he would have been proud to serve had beaten "the enemy gloriously at Najafgarh, whither," writes Hodson on the 26th, "he pushed on last evening. He has taken thirteen guns and all the camp equipage and property. Our loss was small for the gain, but two of the killed were officers-young Lumsden of Coke's Corps, a most promising fellow, and Dr Ireland. The victory is a great one, and will shake the Pandies' nerves, I calculate. All their shot and ammunition were also captured. The 1st Fusiliers were as usual 'to the fore,' and did equally well as usual. I am much disappointed at not having been there; but Mactier would not hear of it, as the weather was bad, and I should have run the risk of another attack of dysentery, from which I have been suffering."

There was great rejoicing throughout the camp over the hardest blow which had yet been struck at the Delhi mutineers, by a regimental captain of thirty-four years, who had once more proved his fitness for high command.

On the day of Nicholson's return to camp Hodson welcomed the arrival of two more troops of recruits for his own regiment. "Such an experiment," he says with just pride, "as raising a regiment actually

I Hodson of Hodson's Horse. 
in camp on active (and very active) service was never tried before."

On the 28th he hears that "Havelock has retreated, leaving Lucknow still unrelieved. I cannot understand this, but we have not sufficient information to enable us to judge. After all, Nicholson is the general after my heart."

Towards the end of August the sickness in camp had greatly increased, and on the last day of the month 2368 men were in hospital. "Nothing is going on here of public importance," writes Hodson on September 3, "and everything is stagnant save the hand of the destroying angel of sickness: we have at this moment 2500 in hospital, of whom 1100 are Europeans, out of a total of 5000 men (Europeans), and yet our general waits for this and that arrival, forgetful that each succeeding day diminishes his force by more than the strength of the expected driblets. He talks now of awaiting the arrival of three weak regiments of Gulâb Singh's force under Richard Lawrence, who are marching from Umbâla. Before they arrive, if the general really does wait for them, we shall have an equivalent to their numbers sickened and dying from the delay in this plague spot. 'Delhi in September' is proverbial, and this year we seem likely to realise its full horrors. The train will be here to-morrow or next day, and I hope our general will not lose a day after that."

On September 4 the long train of heavy guns and mortars drawn by elephants, followed by miles of bullock-carts laden with shot, shells, and ammunition of all kinds, was escorted safely into camp by Bourchier's battery and two squadrons of the 
9th Lancers. "The supply of shot and shell," says Greathed, "seems sufficient to grind Delhi to powder." The arrival of those sixty guns, howitzers, and mortars, preceded or followed by a few hundred fresh troops from the Punjâb, Firozpur, and Meerut, filled every heart in camp with the promise of a glorious ending to the toils, struggles, and anxieties of the past three months.

All through that first week of September nearly the whole of Wilson's troops were employed in making ready for the assault which our heavy guns would shortly open against the doomed city, where mutiny and murder had run riot upon that woeful Monday in May. "To-night," says Hodson, writing on the 6 th, "I believe the engineers are really to begin work constructing batteries, so that in two or three days Delhi ought to be taken. If General Wilson delays now, he will have nothing left to take: all the sepoys will be off to their homes, or into Rolilkhand, or into Gwalior." 


\section{CHAPTER XVI.}

THE STORMING OF DELHI. SEPTEMBER 1857.

Nigнt after night from September 7 a fresh battery was traced, erected, and armed with its due proportion of heavy guns, howitzers, and mortars. Each succeeding day a new battery began to pound the walls or hurl its shells among the outworks of the imperial city. On the morning of the 12 th some fifty of our heavy guns and mortars were in full play upon the crumbling walls and bastions, giving the enemy no rest from their deadly hail until the morning of the 14th, when the storming columns were formed up for the final assault.

During that week of intense excitement Hodson spent all his leisure moments among the trenches. An artillery officer afterwards told the Rev. G. H. Hodson that even when his brother might have taken rest he would go instead to work in the batteries, and "exposed himself constantly in order to relieve some fainting gumner or wounded man." 1 From the trenches he would ride out with his men against parties of rebel horsemen, who fled promptly back to the cover whence they had emerged. On the 13th he rejoiced to learn that at Nicholson's

1 Hodson of Hodson's Horse. 
own request he was to accompany the column which Nicholson, after the capture of Delhi, would lead in pursuit of the mutineers. "I am very glad for my own sake," he writes, "that I am to go on, for this place is dreadfully unhealthy, and I feel that I shall certainly be ill if I remain here much longer. In fact, I had made up my mind not to remain if possible, and when Nicholson urged my going on with him I was only too ready to second the motion, for I am able to work and to fight, and I must do so as long as I can."

On the evening of the 13th it was known in camp that Delhi would be assaulted on the morrow, and that one of the storming columns would be led by the all-daring Nicholson himself. "We had been so long sitting before this doomed city," says Sir H. Gough, "in the most trying heat and with apparently fruitless labour, that the immediate hopes of an end gave us all a most pleasurable feeling. Knowing, as all did, that a desperate struggle was at hand, few probably felt anything but intense excitement and delight."

On that same evening Hugh Gough himself happened to have a talk with one of his native ofticers, Risaldâr Mân Singh, a fine old Sikh, who had fought against us both in the Satlaj and the Punjâb campaigns. "We discussed the question of to-morrow's big fight. As the old man was fond of telling the story even to his dying day, to my own boys amongst others, it runs in his words as follows: "Gough Sahib came to me on the day before the assault and said, "Mân Singh, there is going to be a great battle to-morrow, and we are going to take Delhi. Hodson says he will ride to 
Jehannum after the Pandies. I wonder how it will end." I said to Gough Sahib, "Well, sahib, wherever Hodson goes we'll all go"; whereupon Gough Sahib said, "Well, Mân Singh, salaam; then we'll all go to Jehannum together."

"I cannot vouch for the strict accuracy of this story, but one and all of us were prepared to follow Hodson to the very death, and I am sure there was not a desponding heart in the whole force." 1

The morning of that sultry 14th of September dawned upon three columns of British and native foot ready at all costs to fight their perilous way inside the northern face of the great rebel stronghold, which many of their number had been looking at so longingly for more than three months past. Every man there, from John Nicholson down to the youngest private, knew how much depended on the issue of what General Wilson mournfully regarded as a gambler's throw.

"If we fail, we fail;

But screw your courage to the sticking-place, And we'll not fail,"

was the feeling which braced every other heart in Wilson's heroic force, emptying the hospitals of men eager to share in the coming struggle, or at least to relieve their healthier comrades from the work of guarding a half-deserted camp.

Meanwhile a fourth column, composed of Reid's war-loving Gurkhas, the Guide infantry, and a few score of white soldiers withdrawn for the time from picket duty, aided on their right by Richard Lawrence's Kashmir Contingent, was ordered to advance against the Kishnganj suburb, where a

1 Gough's Old Memories. 
strong body of rebels had taken up their post. The advance of this column over very difficult ground, under a galling fire of guns and musketry, was soon checked by the fall of its gallant leader, Major (afterwards Sir Charles) Reid, who was carried off severely wounded from the field. The Kashmiris on the right were driven back in hopeless disorder with the loss of four guns. After some hard fighting the rest of Reid's column fell back to their old positions in the Sabzi Mandi.

By this time - about 7 A.M. - Hope Grant's cavalry, about 600 strong, who had been drawn up that morning along the ridge in front of Delhi, were speeding towards Kishnganj in order to prevent the rebels there posted from re-entering the city and impeding the progress of our victorious troops inside. On taking up their new position they encountered, says Gough, "a most severe fire of round-shot, shrapnel, and grape from the walls, to which we could only reply by an equally determined fire from our guns, of which, I think, we had ten in action." 1

It was then that Hope Grant "saw Brigadier Nicholson on the top of the Mori Bastion leading on his brigade. He called out to me that the fighting was going on well for us in the town, and that he was on his way to attack the Lahore gate and bastion, about 500 yards farther on. Forward he went; but the gate was defended so obstinately that he could not dislodge the enemy; he himself was mortally wounded, shot through the body, and his brigade was obliged to retire."

"A few men," he adds, "of the 9th Lancers who

1 Hugh Gough's Old Memories. 
had learned to serve guns were dismounted; they scrambled up the breach in the Mori Bastion, and directed the abandoned guns with great effect against the rebels, who were at this time advancing to attack us. But the failure at the Lahore Bastion left its defenders at liberty to assume the offensive. They turned a 24-pounder gun against us, and with grape inflicted a terrible loss on our men, who were not more than 500 yards distant. Tombs' troop lost 27 men out of 48 , and 19 horses. Two guns of a battery under Lieutenant Campbell suffered in proportion; the 200 men of the 9th Lancers had 42 men and 61 horses killed or wounded; and the Guide cavalry, which was in support, 15 men and 19 horses." 1

"For more than two hours," writes Hodson, whose own men formed part of Hope Grant's force, "we had to sit on our horses under the heaviest fire troops are often exposed to, and that, too, without the chance of doing anything but preventing the enemy coming on. . . . My young regiment behaved admirably, as did all hands. The loss of the party was, of course, very severe. . . .

"I am most humbly and heartily grateful to a merciful Providence that I was spared."

An officer who was present during this sharp ordeal wrote thus to his wife: "I found time for admiration of Hodson, who sat like a man carved in stone, and as calm and apparently as unconcerned as the sentries at the Horse Guards, and only by his eyes and his ready hand, whenever occasion offered, could you have told that he was in deadly peril, and the balls flying amongst us as thick as hail."

1 Incidents in the Sepoy War. 
To the splendid daring of our Horse Artillery, and the patient courage of the 9th Lancers, Hope Grant's despatch was of course to bear eloquent witness. But his praise was not reserved for them alone. "I have never," he writes, "in the whole course of my life seen so much bravery and so much noble conduct displayed by men as was the case in the brigade I had the honour to command."

Speaking of the native cavalry, he says: "Nothing could be steadier, nothing could be more soldier-like, than their bearing. The Guide cavalry, commanded by Captain Sanford-a most excellent and useful officer on outpost duty - lost one native officer killed, and one non-commissioned officer and fourteen privates wounded. Lieutenant Hodson commanded a corps raised by himself, and he is a first-rate officer, brave, determined, and clearheaded. Lieutenant Watson, commanding the 1st Punjâb Cavalry, Lieutenant Probyn, commanding the 2nd, and Lieutenant Younghusband, the 5th Pânjab Cavalry, are also most excellent officers. I was afterwards joined by Captain Bourchier's battery, which was of great service, and enabled us to hold our position." 1

That 600 horsemen, of whom only a third were British, should have sat unmoved for two long hours under so fierce a hurricane of lead and iron, was a feat of heroic endurance surpassing the famous charge of Cardigan's Light Brigade upon the Russian guns at Balaklava. And this feat, unlike that other, was rewarded with entire success. It was of rital importance that the enemy in Kishnganj should be held in check while our

\footnotetext{
1 Forrest.
} 
storming columns were making good the ground they had won inside the city. "It certainly was a critical time," says Sir Hugh Gough; "but the movement had the desired effect, and heavily as our brigade suffered, it was satisfactory to know that we had done our duty and had borne a good, if passive, share in the day's fighting."

That afternoon Wilson removed his headquarters into that part of Delhi which the columns led by Nicholson, Jones, and Campbell had already won against fearful odds at the cost of many hundred slain and wounded. Nicholson himself lay slowly dying in the tent to which he had been borne outside the city,- -struck down, as Hodson wrote, "at a time when his services were beyond expression valuable." It was there that on the following evening Hope Grant found the hero whom he "had last seen upon the walls of Delhi the day before, vigorous and animated, leading on his men gallantly. . . .

"He was like a noble oak riven asunder by a thunderbolt. As I approached he looked towards me, and in a deep sepulchral voice said, "Who are you ?' I told him, and spoke some kind words to him. He looked again, and after some time, with great difficulty, said, 'I thank you,' and then closed his eyes. It was the last words I heard him speak, and the last time I ever saw him."

On the night of the 14th Hodson's Horse bivouacked about Ludlow Castle, between the city and the ridge. On the 15th, while our troops were making slow but steady progress within the city, Hodson found time to assist at the burial of

${ }^{1}$ Incidents in the Sepoy War. 
the brave Major Jacob, who had fallen in the act of leading his men up the lane where Nicholson was struck down. "He was a noble soldier," writes Hodson, "and delighted us all by his bearing. His death has made me a captain, the long-wished-for goal; but I would rather have served on as a subaltern than gain promotion thus. Greville and Owen are doing well, but I much fear there is no hope for poor Nicholson: his is a cruel wound, and his loss would be a material calamity."

On the 16th he writes again: "I have just returned from a very long and terribly hot ride of some hours to ascertain the movements, position, and line of retreat of the enemy, and I can do no more than report my safety. . . . All is going on well; the magazine was carried by storm this morning with nominal loss, and our guns are knocking the fort and palace about. All the suburbs have been evacuated or taken. I have just ridden through them, and all the enemy's heavy guns have been brought into camp."

In the same letter he speaks of General Wilson as "fairly broken down by fatigue and anxiety,he cannot stand on his legs to-day: fortunately Chamberlain is well enough to go down and keep him straight, and Colonel Seaton also-two good men, if he will be led by them."

By the death of Major Jacob Lieutenant Hodson gained not only his company, but the brevet-majority for which he had so long been waiting, as a reward for his services during the Punjâb campaign.

The next two days were spent in strengthening our front from the magazine to the Kâbul gate. The old Delhi Bank and several strong buildings 
were carried with no great loss, and our mortars played incessantly upon the palace and the old Pathan fort of Selimgarh. "Not above 3000 or 4000 of the rebel troops remained in the city," wrote Hodson on the 17th. "Headquarters are there, and I am going down immediately to take up my quarters with the staff. . . . I am thankful to say Nicholson is a little better to-day, and there appears some hope of his recovery, though a very slight one."

On the following day he wrote: "Poor Nicholson is lying in a terribly dangerous state. I would give a year's pay to know he would recover, so deeply do we feel his loss at a time like this."

On the evening of the 19th the Burn Bastion, which five days earlier had stayed the advance of Nicholson's stormers, was surprised and captured by a party from the Kâbul gate. Early the next morning the Lahore gate and Garstin Bastion were also carried. With the bloodless capture of the palace itself the whole city fell that day into our hands. On the same morning (20th) Hope Grant took all his available cavalry on a reconnaissance to the west of the city. Hodson of course accompanied the brigadier, who had strict orders not to go under fire. "We all marched out," he says, "to the top of the hill on which stands the 'Idgarh,' and thence, from a safe and respectful distance, overlooked the camp of the Bareilly and Nasirabad force, under 'General' Bakht Khan, quondam subadar of artillery." A look through his glass, followed by the sound of a loud explosion, convinced Hodson that the enemy were abandoning their camp. On this fact being confirmed by his own messengers 
he immediately got leave to carry the news to General Wilson.

This he did, "galloping down along the front of the city to see if that was quite clear. I then asked leave to go down through the camp and see what was really the state of the case; and M'Dowell and I started with seventy-five men and rode at a gallop right round the city to the Delhi gate, clearing the roads of plunderers and suspicious-looking objects as we went. We found the camp, as I had been told, empty, and the Delhi gate open: we were there at 11 A.M. at latest, and it was not until 2 P.M. that the order was given for the cavalry to move out, and they were so long about it that when at sunset M'Dowell and I were returning (bringing away three guns left by the enemy, and having made arrangements and collected camels for bringing in the empty tents, \&c.) we met the advance guard coming slowly forward in grand array! We had been on to the jail and old fort, two or three miles beyond Delhi, and executed many a straggler. I brought in the mess plate of the 60th Native Infantry, their standards, drums, and other things. M'Dowell and I had been for five hours inside the Delhi gate, hunting about, before a guard was sent to take charge of it."

On the same day Hodson had been " much shocked (even familiar as I have become with death) by poor Hervey Greathed's sudden death yesterday from cholera: the strongest and healthiest man in camp snatched away after a few hours' illness. . . . What a harrest of death there has been during the past four months, as if war was not sufficiently full of horrors!... None but those who fought through 
the first six weeks of the campaign know on what a thread our lives and the safety of the empire hung, or can appreciate the sufferings and exertions of those days of watchfulness and combat, of fearful heat and exhaustion, of trial and danger. I look back on them with a feeling of almost doubt whether they were real or only a foul dream. This day will be a memorable one in the annals of the empire: the restoration of British rule in the East dates from the 20th September 1857."

"We now ascertained," says Sir Hope Grant, "that Delhi had been evacuated during the night. India was saved; and the fearful struggle which had shaken the nation to its foundation was passing away like a heavy thunder - cloud from before the sun. There was no longer any danger to be apprehended from the Punjâb, and we heard that British troops were fast pouring into Calcutta." 1

Delhi had fallen, and the Punjâb was safe, but the old king himself and all his family, many of whom had taken part in the massacres of May 11, were still at large, and their name alone might be a rallying-point for fresh risings against our rule. Hodson learned that the king had fled with a crowd of followers and kinsfolk to the tomb of his ancestor Humâyun, about five miles from Delhi, on the road to the far-famed Kutab Minâr. Foreseeing the trouble that might ensue from the unhindered escape of Bahâdur Shah, Hodson begged hard for leave to ride after the fugitives and bring the old king back a prisoner, on the only terms that could be granted him,- the lives, namely, of himself, his favourite wife, and her son, Jamma Bakht.

\footnotetext{
1 Incidents in the Sepoy War.
} 
Only after much pleading was he allowed to go forth upon his dangerous errand. "This," writes Hodson, "was successfully accomplished, at the expense of vast fatigue and no trifling risk." $\mathrm{He}$ and his fifty horsemen had to thread their way through miles of ruinous tombs, palaces, and other buildings which marked the site of Old Delhi. About a mile from Humâyun's tomb the road passed under the old Fort, to which the king had first fled for shelter, and which was still thronged with numbers of his adherents. Not a shot, however, was fired on the advancing troop.

On reaching the noble gateway of the wide court, wherein stood the dome-capped glory of the white marble tomb, Hodson concealed his little party in some old buildings hard by. Sending the faithful Rajab Ali and another emissary to negotiate the terms of surrender with the people inside, Hodson himself awaited the issue from his post of observation near the gate. After two hours of the most trying suspense he had ever known, his messengers brought him word that the king would accept the proffered terms if "Hodson Bahâdur" would come forth and repeat with his own lips the promise of the Government for his safety. Thereupon Hodson stepped forward and gave the needful assurance, adding that any attempt at a rescue would be punished by the immediate death of the king. Erelong the train of palkis conveying the royal prisoners and their few attendants passed slowly out of the gate closely guarded by Hodson and his sowars.

The march back to Delhi then began by a longer but less dangerous road, - the longest five miles, as Hodson himself declared, that he had ever ridden. 
For the greater portion of the way his party was followed by a crowd of armed and angry retainers, eager, but yet afraid, to strike a blow on behalf of their captive lord; for they knew that the one Englishman riding there by his side would prove as good as his word on the first sign of an attempted rescue. The English guard at the Lahore gate of the city were only prevented from raising a lusty cheer for the daring Englishman by Hodson's assurance that the old king would regard the honour as intended for himself.

Passing onward through the broad but now deserted Chandni Chauk - the Street of Silversmithsthe party halted at the palace gate, where Hodson made over his royal charge to the new Commissioner, $\mathrm{Mr}$ Charles Saunders, for safe lodgment in their former home. "By Jove! Hodson," exclaimed the admiring Saunclers, "they ought to make you commander-in-chief for this." On arriving at Wilson's quarters to report his success, and to deliver up the royal arms, he was greeted by his general with the gruff remark, "Well, I am glad you have got him, but I never expected to see either him or you again!"

The successful capture of Bahâdur Shah, the ostensible head of the great rebellion, proved the fitting sequel to the heroic struggle in which Nicholson's stormers, seven days earlier, had led the way. Not content even with this brilliant exploit, Hodson urged the general to let him go forth in quest of "the villain princes," who had taken a leading part in the massacres of May. Not until the dying Nicholson had roused himself to urge the need for swift and stern action did Wilson bring himself to 
yield a grudging consent. "But don't let me be bothered with them," he grumbled forth. "I assured him," says Hodson, "that it was nothing but his own order which 'bothered' him with the king, as I would much rather have brought him into Delhi dead than living."

Early on the morning of the 22nd Hodson, with his subaltern M'Dowell and a hundred picked horsemen, started upon his second visit to Humâyun's tomb. "I laid my plans," writes Hodson, "so as to cut off access to the tomb or escape from it, and then sent in one of the inferior scions of the royal family (purchased for the purpose by the promise of his life) and my one-eyed maulvi, Rajab Ali, to say that I had come to seize the Shahzâdas for punishment, and intended to do so dead or alive. After two hours of wordy strife and very anxious suspense they appeared and asked if their lives had been promised by the Government, to which I answered, 'Most certainly not,' and sent them away from the tomb towards the city under a guard."

Hodson then proceeded to the tomb, which was crowded with several thousands of the "servants, hangers-on, and scum of the palace and city." With characteristic boldness he ordered them at once to surrender their arms and baggage. "In less than two hours they brought forth from innumerable hiding-places some 500 swords and more than that number of firearms, besides horses, bullocks, and covered carts called 'ruths,' used by the women and eunuchs of the palace."

Leaving the arms and animals in charge of a small guard, Hodson hastened to rejoin his prisoners on their way back to Delhi. 
"I came up just in time, as a large mob had collected and were turning on the guard. I rode in among them at a gallop, and in a few words I appealed to the crowd, saying that these were the butchers who had murdered and brutally used helpless women and children, and that the Government had now sent their punishment: seizing a carbine from one of my men, I deliberately shot them one after another." "God is great!" was the cry that broke from a multitude of lips, and slowly but quietly the crowd of awestricken Mussulmans melted away.

"I am not cruel," he adds, " but I confess I did rejoice at the opportunity of ridding the earth of these wretches. I intended to have had them hung, but when it came to a question of 'they' or ' us,' I had no time for deliberation."

All things considered, it is hard to see, as I have remarked elsewhere, why this deed of summary justice should have provoked the indignant censures of more than one historian. It might have been best, for certain reasons, had the slaughtered princes lived to undergo a regular trial. But Hodson had gleaned from fairly trustworthy sources evidence which convinced him of their actual guilt. He had been virtually told to deal with them as he thought fit. A man so brave and cool in any crisis was little likely to overrate the danger which threatened his small party from a crowd of angry natives, many of whom bore arms which they had even begun to use. To shoot the princes with his own hand seemed only the natural act of one who saw the danger of a moment's delay, and scorned to shift upon other 
shoulders the risk or the burden of a deed best done at such a moment by himself. ${ }^{1}$

"I heard the whole story," says Sir Hugh Gough, who had not himself been present, "from M'Dowell directly afterwards, and from Risaldâr Mân Singh, and other native officers, and his and their undivided testimony was, that as Hodson with his small escort of only a hundred sabres was approaching Delhi the natives crowded round in such numbers, and made such unmistakable signs of attempting a rescue, that the only step left was their death. As M'Dowell said, 'Our own lives were not worth a moment's purchase." "2

"Strange," wrote Hodson five months later, "that some of those who are loudest against me for sparing the king are also crying out at my destroying his sons. . . . But, in point of fact, I am quite indifferent to clamour either way. I made up my mind at the time to be abused. I was convinced I was right, and when I prepared to run the great physical risk of the attempt, I was equally game for the moral risk of praise or blame. These have not been, and are not, times when a man who would serve his country dare hesitate as to the personal consequences to himself of what he thinks his duty."

There is no doubt, at any rate, that Hodson and his small escort were in imminent danger from the crowd that pressed around them. "All I can say," as Dr Anderson, surgeon to Hodson's Horse, afterwards assured the dead man's brother, "is, that I dressed the wounds of my own orderly, who came back with his ear half cut off."

1 Trotter's India under Victoria.

2 old Memories. 
Before shooting the Shahzâdas-two sons and grandson of the captive king-Hodson had made them strip off their outer garments, not, as some kind people have argued, with a view to plunder, but merely in order to crown the ignominy of their doom. "No one ever thought out here," wrote Sir T. Seaton, "of asking why he stripped the princes, or rather why he made them take off their upper garments. It certainly was not, as the French stupidly assert, 'pour ne pas gâter le butin'; for if the upper corresponded with the nether clothes in which the bodies were laid out, they would have been dear at a shilling the lot. . . Some people ask, 'Why did he shoot them himself?' To this I will reply by another question, 'What would have been the effect on that vast crowd of a single moment's hesitation or appearance of hesitation?"

It is hardly too much to say that the summary execution of the guilty princes-for of their guilt there was no shadow of a doubt-was hailed with unquestioning approval by every Englishman in Upper India. Sir Robert Montgomery's note to the author of what has since been called " a stupid, coldblooded, threefold murder," may be said to have voiced the general feeling of the day:-

"Mr dear Hodson,-All honour to you (and to your 'Horse') for catching the king and slaying his sons! I hope you will bag many more!-In haste, ever yours,

R. Montgomery."

"Three of the Shahzâdas" - to quote from Wilson's own despatch of September 22- "who are known to have taken a prominent part in the atrocities at- 
tending the insurrection, have been this day captured by Captain Hodson and shot on the spot.

"Thus has the important duty committed to this force been accomplished, and its object attained,Delhi, the focus of rebellion and insurrection, and the scene of so much horrible cruelty, taken and made desolate; the king, a prisoner in our hands; and the mutineers, notwithstanding their great numerical superiority and their vast resources in ordnance and all the munition and appliances of war, defeated on every occasion of engagement with our troops, are now driven with slaughter, in confusion and dismay, from their boasted stronghold."

In the same despatch General Wilson especially commends the services of "Captain W. S. R. Hodson, who has performed such good and gallant service with his newly raised regiment of irregular horse, and at the same time conducted the duties of the Intelligence Department under the orders of the quartermaster-general with rare ability and success." 1

Some indeed there were among Wilson's officers who held that the punishment of the princes might have been left to other hands than those of their self-appointed executioner. Sir Hugh Gough, for instance, regrets that Hodson should have placed himself in "a position unworthy of so brave a man. The wretched princes, cowards and miscreants as they were, deserved their fate, and I have always held that Hodson was right in all he did, only excepting that one false step." 2

In his delightful antobiography Lord Roberts 1 Forrest's Selections.

2 Old Memories. 
"was rather startled" on seeing the lifeless bodies of the three princes lying exposed on the stone platform in front of the Kotwâli. On learning how and why they had been thus treated he admitted the justice of their punishment, but regretted that in playing the part of executioner Hodson should have "cast a blot on his reputation," and furnished his detractors with a fresh theme for their invective against a soldier at once so brilliant and so bloodthirsty. "It must be understood," says Lord Roberts, "that there was no breach of faith on Hodson's part, for he steadily refused to give any promise to the princes that their lives should be spared : he did, however, undoubtedly by this act give colour to the accusations of bloodthirstiness which his detractors were not slow to make." ${ }^{1}$

It may be taken for granted that no man with fine feelings-such as Hodson was by birth and breeding -would willingly offer himself for the post of a common hangman. But there may be moments when the best of men is called upon to choose between his finer feelings and his apparent duty to the State. That such a moment had come in Hodson's career is hardly open to reasonable doubt. Sir Hugh Gough, writing afterwards to Hodson's brother, told him "that he heard both from $M^{\circ}$ Dowell and the native officers that it was a 'touch-and-go' affair; that Hodson's own men were wavering; and that nothing but his prompt and decisive action could have saved them." "The increasing crowd," wrote M'Dowell, "pressed close on the horses of the sowars, and assumed every moment a more hostile appearance. 'What shall

${ }^{1}$ Lord Roberts's Forty-one Years in India. 
we do with them?' said Hodson to me. 'I think we had better shoot them here; we shall never get them in.' . . . There was no time to be lost.

"We halted the troop, put five troopers across the road behind and in front. Hodson ordered the princes to strip and get again into the cart. $\mathrm{He}$ then shot them with his own hand. So ended the career of the chiefs of the revolt, and of the greatest villains that ever shamed humanity. Before they were shot Hodson addressed our men, explaining who they were and why they were to suffer death. The effect was marvellous: the Mussulmans seemed struck with a wholesome idea of retribution, and the Sikhs shouted with delight, while the mass moved off slowly and silently."

Writing to his wife on the 25th, Hodson congratulates himself on his success " in destroying the enemies of our race; the whole nation will rejoice, but I am pretty sure that however glad — will be at their destruction, he will take exception to my having been the instrument, in God's hands, of their punishment. That will not signify, however : I am too conscious of the rectitude of my own motives to care what the few may say, while my own conscience and the voice of the many pronounce me right."

In another letter Hodson says: "The execution of the princes could be hardly called one of "unresisting' enemies, since they were surrounded by an armed host, to whom we should have been most unquestionably sacrificed if I had hesitated for an instant. It was they or we, and I recommend those who might cavil at my choice to go and catch the next rebels themselves! . . . I must be prepared to 
have all kinds of bad motives attributed to me, for no man ever yet went out of the beaten track without being wondered at and abused; and so marked a success will make me more enemies than friends, so be prepared for abuse rather than reward. For myself I do not care, and I am proud to say that those whose opinion I value most highly think I did well and boldly."

The able writer in 'Blackwood,' from whom I have before quoted, declares that " a very careful study of existing evidence, as well as personal examination of the locality and distances traversed, lead us to the conclusion that Hodson certainly considered that the success of his enterprise, if not the lives of himself and his men, depended on instant action."

It must be remembered also that Wilson had distinctly begged him not to bring back any more prisoners, for he "would not know what to do with them." 1 Hodson might, of course, have handed them over to the civil power, if it had not become, for himself and his small escort, a question of slaying or being slain. With a bold disregard of fine sentiment and personal responsibility- that bugbear of all weak minds-Hodson proceeded to solve the question in his own masterful and fearless way. On the whole, I think that the impartial reader will be guided to a fair judgment on this matter rather by the concurrent testimony of actual eyewitnesses than by the comments of misinformed or quite unfriendly

1 Colonel Thomas Seaton of the 1st Bengal Fusiliers was present when Hodson reported to the general that he had information of the princes being at Humâyun's tomb, and had asked leave to go and capture them. The general answered, "Go at once and take them if possible ; but for God's sake do not bring them in, if you can help it, for I should not know what to do with them." 
critics. I hope, at anyrate, that he will refrain from branding a deed of stern necessity as "a stupid, cold-blooded, threefold murder."

1 "The only time," says General C. Thomason, "I ever saw Hodson otherwise than cheery was one day when I dropped in on him and found him 'writing his defence,' as he called it, over the matter of the capture of the King of Delhi and the execution of the three princes. Poor fellow, he could not understand being called to account for a feat which must ever stand out in history as unbeaten by any Englishman, which is saying a good deal. . . .

"No one knew better than Hodson all the details of the horrible enormities of which these princes had been guilty in connection with the massacre of the captured English women and children, some days after the actual breaking out of the Mutiny on May 11... .

"But why execute them with his own hand? is the question of ten asked. .. I will give Hodson's own reply to this question as he gave it to me.

"'The blood of the innocent women and children who had been the victims of the ferocity of these scoundrels seemed to cry aloud to me as their countryman sent by Providence to avenge their wrongs; and if I had hesitated for an instant in performing with my own hands what I considered a sacred duty, I should never again have been able to look an Englishman in the face.'

"In common with the rest of us at Delhi, who had no reason to be jealous of him, I have often wondered at Hodson never having been made a V.C. for this, if for no other gallant action. The reply of an old schoolfellow of mine, who knew Hodson well, was, 'I suppose it was because he won it every day of his life." 


\section{CHAPTER XVII.}

FROM DELHI TO UMBÂLA. SEPT.-NOV. 1857.

ON the morning of September 23 Nicholson's great soul passed away from the scene of his last and most glorious achievements. He had lived, indeed, to know that he had not fought and fallen in vain. But in every Indian station a cry of sorrow for the loss of such a leader rang out through the general rejoicing over the fall of Delhi and the capture of its king. In the words of the eloquent historian of the 'Sepoy War,' "Then from city to city, from cantonment to cantonment, went the chequered tidings: Delhi had fallen, the king was a captive-but John Nicholson was dead." ${ }^{1}$ Among those who mourned most deeply the death of such a man at such a moment was Hodson himself: "With the single exceptions of my ever-revered Sir Henry Lawrence and Colonel Mackeson, I have never seen his equal in field or council: he was pre-eminently our 'best and bravest,' and his loss is not to be atoned for in these days."

The fall of the imperial city on the Jumna broke the neck of a wide-raging rebellion before a single soldier of the thousands then on their way from

1 Kaye's Sepoy War, vol. iii. 
England had set foot on Indian ground. But many months of hard toil and frequent fighting had yet to elapse before the hydra-headed monster ceased to breathe. A few days after the capture of Bahâdur Shah the soldiers of Outram, Havelock, and Neill fought their way at a terrible loss into the beleaguered Residency of Lucknow. But it was more than two months before Sir Colin Campbell, the new commander-in-chief, could withdraw the reinforced garrison from their battered defences; and not until four months later was Lucknow itself, the capital of the province which had so long served as the recruiting-ground for the Bengal army, destined to fall after a severe struggle into the hands of its former masters.

Neanwhile there was plenty of work in store for Hodson's Horse. On the morning of the 23rd Hodson came into camp "to see after the march of a detachment of my regiment which is ordered, after half-a-dozen changes, to accompany a movable column which is ordered to proceed towards Agra to-morrow. I am to remain here, and, to tell the truth, the business is so mismanaged that I have ceased to care whether I go or stay. I fancy they find me too useful here. We move down bodily to or near the town to-morrow, and everything is in confusion and bustle."

To his great delight, Lieutenant Hugh Gough was selected by Hodson to command the wing of his regiment ordered to march with Colonel Greathed's column towards Agra. "Colonel Seaton has given up the prize agency in disgust," writes Hodson on the 26th, "and I refused it altogether: he is taking you a real trophy from Delhi, no less than the 
turquoise armlet and signet rings of the rascally princes whom I shot,-not actually worth twenty shillings, but I know they will be prized by you and the dear ones at home." On the 27 th he himself, with the remainder of his Horse, joined the column which Brigadier Showers-" a most gentlemanly person and gallant soldier, but sadly prolix and formal in all his arrangements" - was to lead against the rebels in the adjacent districts of Gurgâon and Rewâri.

On October 1 he rejoices to hear "that the detachment [of Hodson's Horse] under Hugh Gough, who were sent with the column across the Jumna, behaved extremely well in that action at Bolundshur, and have been much praised. I am very glad, indeed, of this: it is a great thing for a new regiment to be successful at a cheap rate in its first encounters; it gives a prestige which it is long in losing, and gives the men confidence in themselves and their leaders. In this affair our loss was trifling, though the cavalry were principally employed. Poor Sarel, 9th Lancers, wounded severely, I am sorry to say."

On the 23rd Hodson begs his wife to "tell he may unhesitatingly contradict the story about the rupees. It was born in Delhi, and was partly the cause of General Wilson's bad behaviour to me. The money, 10,000 rupees, was brought to me late one night by the men, who had been desired (as Colonel Seaton will corroborate) to secure prize property for him and the other agents. We marched at daybreak next morning, and I had only time to make it over to M'Dowell to see it locked up in the regimental chest for safety before we started. 
When I returned, three or four days afterwards, a story had been circulated by the native who had disgorged the coin, that I had kept the money for myself! Of course the very day I returned it was, with heaps of other things, made over to the agents. And so stories go in this world!"

A full account of this very incident was given at the time to Mr Sloggett by one of the prize agents, Major Wriford of the 1st Bengal Fusiliers. On the morning of September 27 twenty troopers of Hodson's Horse had brought from the house of a native banker a bag each of Rs. 500, Rs. 10,000 in all, in exchange for an order signed by Hodson himself releasing the banker from all liability to further search of his premises. The money was safely lodged in the regimental treasure-chest. On learning that this sum had not been duly paid over to the prize agents, General Wilson appears to have assumed that Hodson intended to keep the booty for himself. He ordered Wriford to go with a company of his own men to Hodson's lines, take possession of the regimental chest, and bring it to headquarters. On his way thither Wriford met Hodson, who had just returned to Delhi after an absence of three days. The two men at once proceeded to the general's quarters. On hearing Hodson's report of his recent doings Wilson "burst forth into warmest acclamations of praise. "If I had many like you,' he said, 'we should soon see the country settled quietly down.' Hodson's reply was, 'Now, sir, I beg you to place me under arrest,' at the same time unbuckling and laying down his sword.

"The general, astonished, asked what he meant, 
when he alluded to the order just before given to Wriford. 'Oh,' said the general, 'I had forgotten all about it: yes, I am very sorry, but I was obliged to issue it, because you had signed a release from search to the banker, which no one knew anything about, save that you must have had 10,000 rupees for giving it.' Hodson opened his sabretasche and held out the order for him to do this signed by the general, and then he showed the second order which had taken him off an hour after on the emergent expedition from which he had that moment returned. The general expressed the deepest contrition; said he believed his mind was going-he could remember nothing from hour to hour, and so on; asked Hodson to forgive him and take up his sword again and continue to give him the benefit of his invaluable services. But (Wriford continued in his story to me) 'would you believe it? This thing is still brought up against him. Some men envy and dislike him so much they really don't care what they say.'

The amount of petty jealousy provoked by Hodson's latest achievements was indeed, as he tells his wife, "beyond belief. The capture of the king and his sons, however ultimately creditable, has caused me more envy and ill-will than you would believe possible, but I have had too much experience of humanity during the last few years to care for envy now ; and conscious as $I$ am of my own rectitude of purpose at least, however I may err in judgment, I go on my way rejoicing."

Before the end of October Showers's column had got through a good deal of useful, if not very 1 The Rev. C. Sloggett's letter to the Rev. G. H. Hodson. 
glorious, work. Four or five forts, including those of Kanaud and Jhajar, about sixty guns, seven or eight lakhs of rupees, and plenty of other prize, fell into the brigadier's hands. Hodson and his ubiquitous troopers scoured the country to the south and west of Delhi, giving the disaffected no rest. In the intervals of other work their bold leader wrote daily to his wife a lively record of each day's proceedings.

On the 2nd of October he tells her that he had "remained behind the force for a day in order to settle the business and pay up and discharge my Intelligence establishment. . . . I feel quite a free man now. I have no work to do but my regiment; though, truth to tell, that is quite enough for one man, even with so able and willing an assistant as M'Dowell. I do not reckon on much fighting where we are going, and the weather is now getting very tolerable. The country we are going into is much healthier than Delhi, and I expect much benefit from the change of air and quiet marching. After our return I shall get away, if but for a week; and then my anxiety is to join Napier, wherever he may be."

On the 3rd he speaks of the brigadier as "marching at his favourite pace of six miles in five hours." "I grieve daily," he adds, "in all bitterness for poor Nicholson's death. He was a man such as one rarely sees,-next to dear Sir Henry, our greatest loss."

On the afternoon of the 4th, while the column halted at Gurgâon, he is ordered to go and "punish some refractory villages a few miles off. ... Tell - the swords I have kept are beautiful, and 
historically most valuable. It was like parting with my teeth to give up those I did to the general: I should not have cared so much if he had done anything towards the winning them. It will be something hereafter to wear a sword taken from the last of the House of Timour, which had been girt round the waists of the greatest of his predecessors."

On the 6th he writes from Rewâri that "Tulsi Ram bolted yesterday, and left only an empty fort and his guns behind him: in good hands it would have given us considerable trouble, and he was eridently a clever fellow, and had adroitly and promptly contrived so as to be first in the field, should our power have ceased. We found extensive preparations, and large workshops for the completion of military equipments of all kinds, guns, gun-carriages, gunpowder, accoutrements, and material of all kinds. He had already done much, and in a couple of months his position would have been so strong as to have given him the command of all the surrounding country, as well as the rich town and entrepôt of Rewâri, close to the walls of his fort.

"At the same time he was prepared, if we won the day, to profess that he had done all this solely in our interests and to preserve the district for us from the Gujur depredators. This is now his line of defence. Showers yesterday sent to tell him that if he would come in and give himself up, as well as his guns and arms, he should be treated on his merits. This he would not do, and has eventually sealed his fate by bolting. The extent of his warlike preparations is too obviously the result 
of his really hostile, rather than of his professedly friendly, intentions."

From his letter of October 7 it appears that Hodson had drawn no pay, either for his work as assistant quartermaster-general or for his new regiment, except "an advance of $£ 500$ for current expenditure. I have as yet been able to get no pay abstracts passed; and indeed such is the confusion of all things, from the want of some central authority, that no one knows where, or by whom, we are to be paid; so I have to draw money for my men 'on account,' to be settled hereafter: as yet, however, I take care that it shall not exceed a third, or at utmost half their pay, to be safely within the mark. Men and horses cannot live on 'nothing a-day and find themselves,' and any regular officework is utterly impossible while we are kept so perpetually in the saddle. It is rather hard on a new regiment, ' raised on service,' and a little hard on their commandant too, but all will come straight in the end, I doubt not."

On the 11th he reports everything perfectly quiet about Rewâri: "The weather is really cold in the mornings; we shall all improve by the change, though fever is very prevalent amongst the natives. The Europeans are gaining strength daily."

Writing from Dâdri on the 16th, he speaks of the Nawâb of Jhajar as making his submission to Brigadier Showers: "So not a shot will be fired, for all the swarms of irregular cavalry have dispersed to their homes, or rather to the hills and jungles, for shelter and security. Colonel Greathed's column has reached Agra, and there had a fighta regular surprise, our people being attacked while 
at breakfast! However, the enemy were thoroughly thrashed eventually, and lost camp and guns. Poor French of the Lancers is the only officer whose name I have heard as killed."

A report had just reached him from Simla that Mrs Hodson had "got some magnificent diamond rings, \&c., taken at Delhi. This is rather good, considering the only rings I sent you were the princes', and not worth twenty rupees altogether, and the only 'diamonds' were in that little brooch I bought from a sowar more than a month before Delhi was taken. So much for the veracity of your good-natured friends at Simla!"

$\mathrm{He}$ likes M'Dowell "increasingly - he is so thoroughly honest and gentlemanly, and brave as a lion. In Wise, too, I am fortunate; and Wells is a fat, good-tempered, willing-to-work schoolboy. We do very well, indeed, together, and I have profited by past experience (and perhaps the natural result of increased age and knowledge of the world), but things are very different now from then."

On the morning of the 19th the force of cavalry under Colonel Custance of the Carabineers took possession of Kanaud, "one of the strongest forts I have seen, with fourteen guns, some very heary ones, and five lakhs of rupees, which, alas! is to be considered Government, not prize, property. I was only out of my saddle for one hour yesterday, from one in the morning till sunset, and then only to get some cold food under a tree! But I an quite well and strong, much better than I was at Delhi; and as Colonel Custance and his officers are remarkably agreeable gentlemanlike people, we have had the most really pleasant days since leaving Delhi." 
On the next day Hodson received "a very nice and welcome letter from Grant, dated Calcutta, 5th September. He had had a long talk about me with Mr Talbot, who told him that General Anson's representations had done much good, and that it was admitted on all hands that my exculpation in re the Guides was complete, and that no higher or more flattering testimonials were ever seen; so that, please God, I shall be righted at last,- and justice is all I want."

At Karnaud the column halted for several days. Hodson himself was not sorry for the rest. "My men and horses were beginning to suffer. I had this morning thirty-eight men and forty-three horses sick! My ankle gives me so much pain that I have been forced to take to a small pony to ride even about camp, so as to avoid walking even for fifty yards. I believe it will be good for a sick certificate."

During the halt at Karnaud a certain Khuda Baksh brought into Hodson "untold money and bullion which he digs up, and is very indignant because I insist on its being handed over as prizemoney.

"The detached state of this regiment is enough to ruin it. Three troops are at Agra, or thereabouts, under Hugh Gough; the sick and depot at Delhi, and portions of five troops here; but it seriously increases the difficulty of managing a totally new regiment, and it is hardly fair either to the men or to the commanding officer. I have remonstrated, but I suppose with very little effect, as I have had no answer. I trust, indeed, I may get all together and go towards Oudh." 
On the 29th Hodson was back again in Delhi, "safe and well, but very tired." On his arrival he went straight to call upon General Penny, who had lately taken over the command from General Wilson. General Penny at once granted him the leave for which he had already applied, to visit his wife for a few weeks at Umbâla, whither she had come down from Simla for the cold weather just setting in.

The hours that intervened before his departure from Delhi were mainly spent in arranging for the despatch of his regiment to Meerut. He was feeling sadly in need of rest. "I have been overstrained and over-laboured," he writes on October 30 , "and I want repose. When I get our prizemoney I hope to realise Rs. 40,000, and if so, I shall be able to pay all our debts, and a great burden will be off my heart. I shall feel quite free and young again in heart when all is clear."

The passage just quoted furnishes of itself a convincing answer to the charges of wholesale plunder which Hodson's enemies have continually brought against him. But calumny was soon to find a fresh weapon of attack connected with the incident which I have now to mention.

Among the booty which Hodson had helped to capture were some 1600 head of horned cattle. He at once reported to Brigadier Showers the result of his successful foray. "What in the world am I to do with them?" exclaimed the puzzled brigadier; "it would take half my force to convoy them back to Delhi." " Well, sir," replied Hodson, " will you sell them to me and let me take my chance?" Never had the brigadier been more relieved, as he 
afterwards told Lord Napier, than he felt at the offer thus made to him. He agreed to let Hodson buy the whole lot at two rupees four annas a head. The purchase-money, which Hodson paid over to the prize agent, amounted to Rs. 3491. Under an escort of his own sowars the cattle with their drivers were sent off to Delhi, where the cattle were sold at a very handsome profit.

Out of the proceeds, says the Rev. C. Sloggett, Hodson bought at Umbâla for 1200 rupees a house "which, just before the Mutiny and a few months after, was worth Rs. 15,000, for which I believe he ultimately sold it. At first, however, his wife lived in it, and in grateful remembrance of the mode of its aequisition they bestowed upon it the name of the Cowhouse." The name, in fact, was given as a joke by Hodson himself, who appears to have been in high glee at the result of his lucky speculation.

"Not many weeks elapsed," continues Mr Sloggett, "ere many of the residents had left, and were succeeded by others who, though they knew of Hodson, knew nothing of the circumstances which had enabled him to purchase so large and fine a house, and so the rumour grew and spread that one who was known to have been in debt a short time before must have 'looted' largely ere he could have become the possessor of so valuable a house." 1

Lord Napier's testimony to the truth of a story told by Brigadier Showers needs no corroboration. It may, however, be worth noting here that the late Sir Donald Stewart, who had served on the general staff during the siege of Delhi, declared

1 Rev. C. Sloggett's letter to Mr Bosworth Smith. 
that "there was nothing secret or underhand in the transaction."

On November 2 Hodson rejoined the wife whom he loved so tenderly, with a love which frequent separation and the whirl of engrossing cares, perils, and distractions had served only to deepen and sanctify. No lover could have expressed himself more fervently than he had lately done upon hearing of Mrs Hodson's narrow escape from imminent destruction during one of her rides about Simla. "I am indeed," he writes on October 27, "most humbly and earnestly grateful to the good God who has so mercifully spared what was so infinitely more precious to me than life itself, ${ }^{1}$ and I do feel how entirely our hearts should be filled with gratitude to Him for the bountiful mercies which we mutually and individually have experienced at His hands during the past year-the preservation of us both from such perils; my re-employment in an honourable position; my ability to do such good service to the country at such a crisis; the preservation of health in such a time of exposure; my complete, though tardy, vindication from unjust charges; my almost assured freedom from debt,all these mercies are almost more than my full heart can bear. May God crown all other blessings by granting us a safe reunion!"

On the day after his arrival he writes home to his sister: "I was happy enough to get back here yesterday night and find my wife well, and all but recovered from the effects of her frightful accident-

1 The horse on which his wife was riding missed his footing, fell down a precipice, and was killed. In the act of falling Mrs Hodson saved herself, and almost by a miracle escaped without serious hurt. 
the most wonderful escape, perhaps, from imminent peril ever recorded. I take the first holiday I have had since the 15th May to write a few lines to you, my dearest sister, to say what deep and real pleasure and comfort your letters bring to me, amidst danger and toil and fatigue; and how cheering it is to feel that, come what may, I am sure of your loving sympathy and constant affection. I received yesterday your letter of the 4th May, and could not but be most forcibly struck with the contrast between my circumstances individually and those of the country then and now. No one will rejoice more than yourself at the sudden change, and at the tolerable success which has been permitted to my labours."

Only a fortnight after this happy reunion his leave was cut short by an order to rejoin his regiment on active service.

"We march at once," he writes on the 15th, "to join Sir Colin Campbell and the army assembling at Cawnpore for the reconquest of Lucknow.

"I am getting on famously with my regiment: men of good family and fighting repute are really flocking to my standard, and before the end of the year I hope to have 1000 horsemen under my command.

"I had a letter the other day from - at Calcutta, from which I learn that at last the truth is beginning to dawn on the minds of men in power regarding me. They now say that my remonstrance will be placed on record for preservation, ' not for justification, which is fully admitted was not required,' and that 'no higher testimonials were ever produced.' 
"How much I have to be thankful for, not only for restored position and means of future distinction, but for safety and preservation during this terrible war, and for my dear wife's escape."

One or two pleasing incidents in that brief period of domestic happiness have been thus described by a lady visitor at the Cowhouse: "When at Umbâla, on ten days' leave, in November last, the wounded and convalescent Guides (his old corps) were all day straying into the compound simply to salaam the sahib. And if, when lingering on the steps or in front of the study door, they were questioned what they wanted, their answer would be, 'Nothing; they liked to look at the sahib.' And so they hung about his steps, and watched like so many faithful dogs. Especially there was an Afghan boy (he had once been a slave) whose very soul seemed bound up in the master who had rescued him from his degraded position, and for whom every service seemed light. He would watch his master's movements with a look of very worship, as if the ground were not good enough for him to tread." 


\section{CHAPTER XVIII.}

\section{FROM UMBÂLA TO FATHIGARH.} NOV. 1857-JAN. 1858.

Towards the end of the same month his old friend Colonel Seaton was instructed by General Penny to take charge of an immense convoy about to be despatched from Delhi on the road to Cawnpore, or wherever he might find Sir Colin Campbell. A small force of all arms-absurdly small for a convoy reckoned to cover some eighteen miles of groundwas assigned to him for this purpose. For the success of such a morement Seaton felt that the means of obtaining correct information on all essential points was absolutely necessary. He therefore requested General Penny to let him have Major Hodson and his regiment of horse, instead of the cavalry corps that had been detailed for that duty.

"'But,' urged the general, 'Hodson's corps is not so strong as —'s nor anything like so well mounted.' 'I know that, sir, quite well; but as the safety of the convoy - the whole success of the expedition - will depend mainly on getting accurate information of the enemy, I wish to have Hodson, for I know well that if any man in the world can get it, he is the man. He is indefatig- 
able-a soldier of the highest class; I have unbounded confidence in him, and would rather have him than 500 more men.' The general on hearing this at once acquiesced, and at the same time authorised me to organise an intelligence department." "1

On December 10, after four days of forced marches, Hodson's Horse were encamped some fourteen miles from Aligarh. "We joined the column this morning," writes Hodson, "and march on to Aligarh to-morrow. . . . We have a frightful convoy and crowd, but I hope not for long. The headquarter people, Colonels Keith-Young, Becher, and Congreve, are with us. It is said that our friend Napier is to be adjutant-general of the army -delightful if true. I have only just got my tent up, and it is nearly dark, so I can only say that I an safe and well."

Early the next morning the column reached Aligarh. "Everything perfectly quiet in the neighbourhood," was Hodson's report, "and no large gathering of Pandies anywhere near. There is a small party at Khasganj, and I hope we may be lucky enough to find them, but I doubt their waiting for us. Meantime we are to march down the Trunk Road, halting here to-morrow. I cannot get over our parting - each separation seems a greater wrench than the last. . . . I have 596 sabres with me now, 50 more coming from Delhi, besides the 140 with Gough-not so bad that."

On the following day he hears from Agra that the ladies, together with the sick and wounded from Lucknow and Cawnpore, have been sent down

${ }^{1}$ From Cadet to Colonel. 
to Allahabad, and the Gwalior Contingent beaten. "The commander-in-chief," he adds, "is at Cawnpore, and troops will be assembling there, enough to put down all opposition and open the road to Calcutta. We march to-morrow morning from hence, leaving the impedimenta behind here until we can ascertain that the road is clear: when it is so, all will move on. We have fifteen guns, mostly 9 -pounders, with our small but compact force."

On the 13th he writes from Jalâli: "Your letter enclosing our darling sister's found us lying in the dust, with a pea-soup atmosphere of fine sand all around, discussing hot tea and eggs, just as I had returned from a recomnaissance to the front in virtue of my being big eye and ear of the camp. Apropos of the newspapers, Arthur Cocks [the Civil Commissioner] tells me that the 'Friend of India' has apologised for its strictures on my conduct in re the Shahzâdas; so let that satisfy you, for nothing I could write, or my friends for me, could ever be half so effectual as the 'Friend's' voluntary amende. I intended to have written much to-day, but I was waked at 3 A.M., marched soon after, and with the exception of the dusty breakfast (cheered by my letters), I was in the saddle till half-past 2 P.м. Then regimental business, washed and dressed, then threw myself on my bed for half an hour till dinner, after which we get to bed as soon as we can, and up again at 3 A.M., so there is not much time for what I want to do of private matters. There's a history of a day in camp."

On the morning of the 14th Seaton's column reached Gangêri, about thirteen miles from Khas- 
ganj, between which place and Kuchla on the Ganges large bodies of rebels were said to be encamped. Hodson was at once sent off with a few of his troopers and Seaton's orderly, Najor Light of the Bengal Artillery, to report on the enemy's strength and whereabouts. Seaton had just finished his breakfast when Light came galloping back. "Captain Hodson desires me to tell you, sir, that the enemy's cavalry are advaneing in force on both flanks." Seaton at once ordered his bugler to sound the alarm. In a few minutes the whole force were under arms, and the cavalry, with the guus, were trotting forward from either flank towards a village, beyond which the rebels were advancing to the attack. As our troops moved forward over broken ground, dotted with tufts of tall grass, " the enemy's infantry," writes Seaton, "appeared on the ridge, and their guns began to open on us. The fire of the enemy's guns, subdued by Bishop's battery, had slackened and almost ceased, when Wardlaw, seeing his opportunity, charged and eaptured them. Hodson at the same moment threw his regiment against the enemy's right, and they were driven in confusion from the field, the whole body fleeing precipitately.

"The rebels, completely and utterly routed, abandoned their last gun and two ammunitionwaggons; their infantry threw away their arms, hid themselves in the fields and ravines, or continued their flight headlong over the country." 1

Hodson himself speaks of the magnificent eharge made by the 6th Carabineers and 9th Lancers. "I grieve to say, however, that they paid most dearly

1 From Cadet to Colonel. 
for their splendid courage. All their officers went down. Captain Wardlaw, Mr Hudson, and Mr Vyse, all killed, and Head, of the Lancers, badly wounded. The infantry were not engaged at all. We attacked their flying cavalry and footmen on the left, and made very short work of all we could catch. I lost a fine old riscldâr, our dear old friend Muhammad Reza Khan's brother. None of my officers hurt; but my horse (Rufus this time) got a cut."

Hodson had made good use of his opportunity, " his course," writes Colonel Innes, "being marked for many miles by killed and wounded, amongst whom were twenty-three of his own troopers. The captured guns were brought into camp, and it was nearly 3 P.M. before our troops were able to resume their breakfast." 1

In his despateh to Major-General Penny on December 15 Colonel Seaton paid the following tribute to the services of Hodson's Horse and its dashing leader: "The general will see by the list of casualties that Captain Hodson's newly raised body of horse was not backward, and rendered excellent service. It could not do less under its distinguished commander, whom I beg particularly to mention to the major-general as having on every possible occasion rendered me the most efficient service, whether in gaining informatiou, reconnoitring the country, or leading his regiment."

Before sunset of the 14th a strong party of Hodson's Horse were again in the saddle, pushing on to Bilram, whence they returned some hours

1 Innes's History of the Bengal European Regiment, now the Royal Munster Fusiliers. 
later with such tidings as they could gather by the way. Hodson reported that straggling parties of the rebel cavalry had passed through Bilram, "and that the headman of the place would give us next morning all information concerning the troops of mutineers in Khasganj." 1

Marching on the 15th towards Khasganj, Seaton learned from the people at Bilram that "the rebels had hastily evacuated Khasganj, part of them crossing the Ganges at Kuchla ferry, distant about sixteen miles, and part pushing on to Patiâli, distant twenty-five miles in the direction of Fathigarh, where there was a large force assembled, with a numerous artillery, all under the command of the Hakim, the hereditary commander-in-chief of the Nawâb of Farokhabad."

"It was fortunate for us," he remarks, "that the rebels had evacuated Khasganj. It is a large town, filled with strong well-built brick houses, and outside of it there were extensive old gardens surrounded by earthen walls many feet thick, perfect small forts-quite formidable field-works they would have made. In these gardens, which were filled with large old trees and a wilderness of shrubs and bushes, the rebels had encamped; and if they had defended them at all manfully they would, to say the least, have given us some trouble. Against a contingency of this kind, however, I was well provided, having heavy guns and mortars, and two companies of sappers."

The morning of the 17th saw Seaton's crowning success against the rebels at Patiâli. "The enemy," says Hodson, "had the boldness to await our

\section{Seaton.}


arrival here in great foree and partly intrenched. We attacked them soon after 8 A.M., they firing aimlessly at us as we advaneed, our guns coming into play with fine effect. I then dashed into their camp with my regiment, Bishop's troop of Horse Artillery actually charging with us like cavalry fairly into their eamp! We drove them through camp and town, and through gardens, fields, and lanes, capturing every gun and all their ammunition and baggage. We pushed on for six or seven miles, and read them a terrible lesson. The Carabineers and my men alone must have killed some 500 or 600 at least, all sowars and fanaties. We wound up by killing the Nawâb, who led them on his elephant, after a long ehase and an ingenious struggle, in which he was fairly pulled out of his howdah."

Hodson owned to feeling very tired after eleven hours spent in the saddle. He was, however, "delighted with our day's work on Seaton's account. We have captured thirteen guns and entirely dispersed the enemy. He ought to be made a K.C.B. for this." 1

"I was not very strong," says Seaton, "and nothing but the exeitement kept me up through a hard day's work, such as apparently lay before us, and then only with the help of an easy-paced horse, placed at my disposal by my thoughtful and noble-hearted friend Hodson."

In his despateh of Deeember 18 Colonel Seaton again begged Major-General Penny to bring Major Hodson "and his great and important services to the special notice of the commander-in-ehief."

1 He was made a K.C.B. for his services in the Mutiny. 
After a halt of three days at Patiâli the column returned to its former camping-ground at Suhawir. On the 22nd it marehed on to Khasganj. As it neared that place Arthur Cocks, the active Commissioner, rode up to Seaton and told him that a notorious traitor, Jowâhir Khan, a pensioned risaldâr, who had fought against us at Patiâli, had returned to Khasganj with one of his sons, who had been wounded in the previous fight. Calling up Hodson, the brigadier sent him off with a troop of his regiment to seize the traitor.

"In five minutes that intelligent and energetic officer was off at a sharp trot, which he soon increased to a hand-gallop. As the column neared Khasganj Hodson eame out to meet me. His salutation was, 'I've got him, eolonel. We rode in at a gallop and surrounded his house, burst open the door, found the son and killed him; and the traitor himself, trying to eseape, jumped over a wall into the arms of one of my men.' Jowâhir Khan was no ordinary traitor. He had served our Government long, and was not only enjoying the pension of a riscldar, but the emoluments derived from the Order of British India, of which he was a member."

On the next day he was arraigned before a military court and condemned to death by being blown away from a gun. The sentence was carried out that evening. "Blowing away from a gun," as Seaton remarks, "is an awful-looking death, but it must be almost painless-one sharp pang and all over. It makes a great impression, however, on the speetators, and creates a greater thrill of horror than any other mode of execution." ${ }^{1}$

1 From Cadet to Colonel. 
The captured guns were sent off to Aligarh under charge of Major Eld. On arriving at Etah on the 24th Seaton learned that the Rajah of Mainpûri, who had been raising troops and casting cannon, had now declared his independence, and was blocking the highroad through his dominions. By a series of bold and skilful manœuvres Seaton speedily outwitted his new foe.

"On approaching Mainpûri," says Seaton, "we caught a distant glimpse of the enemy's position away to our left; so, getting the eavalry to make a demonstration as if we were going to form across and march by the road, and to make as much dust as possible, I quietly moved on with the artillery and infantry, our march being concealed by some mounds, a small village, and the nature of the ground. As we approached the stream we came in full view of the enemy, who had been firing at the dust ereated by the cavalry. Immediately they saw us well on their left there was a tremendous hubbub and great confusion, which was increased tenfold when the artillery, dashing through the stream, opened fire and raked their whole front.

"In a few minutes the gunners limbered up, crossed the river again a quarter of a mile lower down, and got into their rear; for the stream, making a sharp turn, ran at right angles to their flank. The enemy were so thoroughly cowed by our prompt and determined onset that they fled at once, followed by the whole of the cavalry and artillery."

Marching on with his guns and infantry towards the Rajah's stronghold, Seaton found it already evacuated. Of the eight guns captured in the ad- 
vance, six were reported good and serviceable, and most of these had evidently come from the foundry in the fort. In the fort itself was " a perfect gunfoundry, models and moulds for casting brass guns, contrivances for boring, melting-furnaces, and quantities of metal."

Meanwhile Hodson's Horse had ridden in pursuit of the flying foe. "We had to ride hard to overtake them," he writes on the 27 th. "They Hung away their arms, and became simple villagers with astonishing rapidity: it would have done credit to the stage. No one hurt but two of my sowars. We have got all their guns, and the Doâb is clear now to Fathigarh."

Writing home to his sister on Christmas Day, Hodson speaks of the fatality which still prevents their spending that anniversary together:-

"My heart is full of deep and earnest prayer for you and all my loved ones, and I try to hope that our next Christmas may be spent at home.

"We march to Karauli to-morrow, and shall be at Mainpûri on the 27 th, there to halt for a few days until the convoy is collected and we can hear from the commander-in-chief. We have just heard that Mayhew is the new adjutant-general, and Norman deputy. This last is a splendid thing, and shows Sir Colin's determination to put the right man in the right place, in spite of all the red-tape and seniority systems in the world! I can hear nothing of our dear friend Napier, but I suppose he is with Sir James Outram."

During the halt at Mainpûri Seaton learned that Sir Colin Campbell had reached Gursahaiganj, on his march to Fathigarh. 
"As Hodson volunteered to open communication with him, I furnished him with despatches, and sent him off on the 30th, accompanied by Lieutenant M'Dowell, and escorted by a small party of his regiment. The chief was reported to be forty miles from Bewar. On the morning of the 31st I marched to Bowgong, and in the evening one of Hodson's sowars rode in to say that Captain Hodson and Lieutenant M'Dowell had left part of their escort at Bewar and had gone on to Chibramau, where they had left the remainder of it and ridden on alone; that after they had left, a body of the rebel cavalry had entered the town, surprised the escort, and cut it up; and that the gentlemen had not since been heard of! Although I knew that Hodson and M'Dowell were two of the most wide-awake officers in the army, I could not but feel very uneasy about them; so I sent off about one hundred of the sowars under an officer, and marched myself an hour before daybreak next morning.

"Every one felt uneasy, for Hodson's brilliant qualities as a soldier had made themselves felt by all. So when at daybreak a sowar rode up and reported that he had returned safe to Bewar, the relief from anxiety was felt by all in camp." I

Leaving fifty of his men at Bewar, fourteen miles from Mainpûri, Hodson sped on with the remainder some fourteen miles farther, to Chibramau. There he left the remaining twenty-five, and pushed on with M'Dowell alone to Gursahaiganj. But the end of their ride was not yet, for there they learned that the commander-in-chief had that day marched some fifteen miles farther to Miran-ke-Serai. "This,"

1 From Cadet to Colonel. 
writes M'Dowell, "was very annoying, but there was no help for it. So we struck out as fast as we could, the more so as we heard that the enemy, 700 strong, with four guns, was within two miles of us."

About 4 P.M., after a ride of fifty-five miles through hostile country, Hodson and M'Dowell reached the camp of the commander-in-chief. Hodson "found him wonderfully fresh and well, and met with a most cordial and hearty welcome from him, General Mansfield, and in fact from all. Bruce and Mackimnon all fat and well. Hope Grant was most cordial. I was much pleased with all I heard and saw; the sight of the sailors and the Highlanders did my eyes and heart good. Such dear wild-looking fellows as these jack-tars are, but so respectful and proper in conduct and manner.

"Our dear Napier is wounded, I grieve to say, though, thank God, not badly, and is left behind at Cawnpore. . . . Sir Colin was very complimentary, and my men, under Gough, have won great distinction and universal praise. I rejoiced to see my old friend Norman in his proper place, the de facto adjutant-general of the army; and Hope Grant has done everything admirably."

"This ride," says Sir Hugh Gough, "was a most gallant achievement, though only one of Hodson's many gallant deeds. It was a ride for life; and yet when he reached the chief's camp he was as cool and calm as if he had only ridden from one brigade to another. 'This cool insouciance was one of Hodson's great characteristics: whether in the heat of action or sitting at mess, he always seemed the same-nothing appeared to put him out. . . 
He had a wonderful knowledge and command of the native language, and was a thorough master of all the various idioms, phrases, and accents peculiar to the different districts through which we were campaigning; and by this knowledge, and his own keen commanding way of applying it, he was able to obtain the surest and best information. Sir Colin was much pleased at the result of his ride, and the opportunity of obtaining from such a reliable source the information he was so anxious to gain." 1

Hodson was closeted for some time with Sir Colin Campbell, who invited him and M'Dowell to dinner in his tent.

During that afternoon-to quote the words of a sergeant in Sir Colin's old regiment, the 93rd Highlanders-" a man of my company rushed into the tent calling, 'Come, boys, and see Hodson! He and Sir Colin are in front of the camp: Sir Colin is showing him round, and the smile on the old chief's face shows how he appreciates his companion.' I hastened to the front of the camp, and was rewarded by having a good look at Hodson; and, as the man who had called us had said, I could see that he had made a favourable impression on Sir Colin. Little did I then think that in less than three short months I should see Hodson receive his death-wound, and that thirty-five years after I should be one of the few spared to give evidence to save his fair fame from undeserved slander." 2

On entering the chief's tent M'Dowell "found Hodson seated by Sir Colin, and carrying on a most

1 Old Memories.

2 Forbes-Mitchell's Reminiscences of the Great Mutiny. 
animated conversation with him. We had a very pleasant dinner, and at 8 P.M. started on our long ride back." They reached Gursahaiganj without an incident, and were half way thence to Chibramau when they were hailed by a fakeer to whom Hodson had given alms on his former journey. From the grateful Brahman they learned that the twenty-five sowars left by Hodson at Chibramau had been attacked by a party of rebels and driven away with the loss of several of their number. He had reason also to believe that some of the rebels were lurking about the road, in the hope of intercepting the two Englishmen.

"We deliberated," says M'Dowell, "what we should do, and Hodson decided we should ride on at all risks. 'At the worst,' he said, 'we can gallop back; but we'll try and push through.' The native came with us, and we started. I have seen a few adventures in my time, but must confess this was the most trying one I had ever engaged in. It was a piercing cold night, with a bright moon and a wintry sky, and a cold wind every now and then sweeping by and chilling us to the very marrow. Taking our horses off the hard road on to the side where it was soft, so that the noise of their footfalls could be less distinctly heard, we went silently on our way, anxiously listening for every sound that fell upon our ears, and straining our sight to see if behind the dark trees dotted along the road we could discern the forms of the enemy waiting in ambush to seize us."

As they drew near Chibramau the guide whispered, "They are there," pointing to a garden in a clump of trees in front. "Distinctly we heard 
a faint hum in the distance. . . Slowly and silently we passed through the village, in the main street of which we saw the dead body of one of our men lying stark and stiff and ghastly in the moonlight; and on emerging from the other side, dismissed our faithful guide, with directions to come to our camp-and then, putting spurs to our horses, we galloped for our dear life to Bewar, breathing more freely as every stride bore us away from the danger now past. We reached Bewar at about two o'clock A.M., and found a party of our men sent out to look for us. Our troopers had ridden in to say they had been attacked and driven back, and that we had gone on alone, and all concluded we must fall into the hands of the enemy. We flung ourselves down on charpoys and slept till daylight, when our column marched in, and we received the hearty congratulations of all on our escape."

The two men had ridden ninety-four miles since six o'clock on the morning of the 30th, Hodson himself having ridden seventy-two miles on one horse. "We astonished the headquarter people not a little," he says. A few hours later on the morning of the 31st Seaton's column marched into camp at Bewar.

Some days afterwards Seaton ascertained that the horsemen from whom Hodson had so narrowly escaped belonged to a body of insurgents that had just been dispersed by Brigadier Walpole's operations along the banks of the Jumna. Unable to cross that river, they had resolved to try and make their way across the Ganges into Oudh. How dangerous was the road along which Hodson and M'Dowell had ridden may be gathered from the 
fact that many of the spies who carried letters from one or another of the columns moving along the Doâb were either killed by the way or failed to reach their destination.

It was fortunate also for Hodson that the rebels had refrained from attacking him on his first ride through Chibramau. "We rode in at one end of Chibramau in the morning," says M'Dowell, "they rode in at the other. They saw us, but we did not see them, as we were on unfavourable ground. Thinking we were the advanced guard of our column, they retired hastily to a village some two koss off. Meanwhile Hodson and I, unconscious of their vicinity, rode on. They sent out scouts and ascertained that only twenty-five of our sowars were in the village, upon which they resumed their march, sending a party to eut up our men, and, I suppose, to wait for our return."

In a hurried letter to his wife on New Year's Day of 1858 Hodson writes: "M'Dowell wrote you a capital account of our expedition to Miran-keSerai, which you will get before this reaches you. He is game to the backbone, but he has not the physical stamina for such an adventure as that. I am sorry to say I lost three of my men killed and four wounded, and my horse, saddle, and bridle (English) were lost. I wish you could coax Captain Swinton out of that horse he got of General Anson's : life, and more than life, sometimes depends on being well mounted."

It is pleasant to know that the faithful fakeer, whose timely information had saved the two officers from almost certain death, was handsomely rewarded, and obtained a post in the public service. 
On the morning of January 2 Seaton himself, in company with Light and Hodson, rode over to the chief's camp near Gursahaiganj, on the road to Fathigarh. "The chief," says Seaton, "had forced the passage of the Kali Nadi, and we came in for the tail of the fight, for there were still dropping shots in every direction." "We did not get back," writes Hodson on the 3rd, "until two this morning, very weary and tired, and now comes an order, just as I am sitting down to write, for my regiment to march at once to join the chief's camp near Fathigarh; so I am again reduced to the mere announcement that I am safe and well. I have just heard that the rebels have bolted from Fathigarh." 


\section{CHAPTER XIX.}

\section{FROM FATHIGARH TO CAWNPORE. JANUARY-MARCH 1858.}

AFTER a night march of twenty-five miles Hodson and his sowars joined Sir Colin Campbell on January 4 at Fathigarh, which was found abandoned as he had foretold. "Our troops," he writes, "are all concentrating here, not a shot having been fired."

Three days later Seaton's column marched into camp. After more than three months of detachment duty, Gough's squadron had now rejoined its regimental headquarters, while its gallant leader returned, not without some natural regret, to his old position as adjutant of Hodson's Horse. Hodson was greatly pleased with the smart appearance of the squadron, " and gave us," says Gough, " considerable kudos for our maintenance of the good name of the regiment, accounts of which he had heard from the commander-in-chief. He had been a little annoyed with me for not having kept him more fully acquainted with all we had been doing, and I had been slack in sending in the usual official information; but I often had not the means of so doing, and even in those days I fear I was not over-fond of 'writing.' However, any little feeling 
of anger on his part soon vanished in his pleasure at finding we had brought anything but discredit on 'Hodson's Horse.'" 1

It was not long, however, before Gough was again to lead his men, in concert with Lieutenant John Watson of the 1st Punjâb Cavalry, on special service about Miran-ke-Serai, in hopes of frustrating the attempt of the infamous Nana Sahib to escape from Oudh into Central India.

Meanwhile on January 6 Hodson himself started on a punishing expedition with a brigade commanded by Colonel Adrian Hope. At Pâlamau, in the Shamsabad district, a great many rebels, including their leader, had been arrested by the civil police and condemned by the Civil Commissioner to death. The doomed men, according to $\mathrm{Mr}$ Forbes-Mitchell, were marched in batches up to a large tree of the banian species, from whose spreading branches they were hanged, a dozen at a time. On the afternoon of the 6th this dismal work began, and by daylight of the next morning 130 men might be seen hanging from one tree.

Then happened an incident which Mr ForbesMitchell has cited in defence of Hodson from the charges of cruelty and bloodthirstiness afterwards levelled at his hero. "During the afternoon of the day of which I write, Hodson visited the squadron of his regiment forming the cavalry of the Civil Commissioner's guard. Just at the time of his visit the Commissioner wanted a hangman, and asked if any man of the 93rd would volunteer for the job, stating as an inducement that all

1 Old Memories. 
valuables in the way of rings or money found on the persons of the condemned would become the property of the executioner. No one volunteering for the job, the Commissioner asked Jack Brian, a big tall fellow who was the right-hand man of the company, if he would act as executioner. Jack Brian turned round with a look of disgust, saying: 'Wha do ye tak' us for? We of the 93rd enlisted to fight men with arms in their hands. I widna' become yer hangman for all the loot in India!' Captain Hodson was standing close by, and hearing the answer, said, "Well answered, my brave fellow. I wish to shake hands with you,' which he did. Then turning to Captain Dawson, Hodson said: 'I'm sick of work of this kind. I'm glad I'm not on duty'; and he mounted his horse and rode off." I

Hodson returned to Fathigarh on the 12th, "not having effected much, though we frightened many, I have no doubt." "A tedious review" on the next day was followed by an interview and a dinner with his chicf. "Nothing," he says, "can be kinder or more cordial than the commander-inchief and General Mansfield."

Next morning Hodson's Horse were encamped on the Ramganga, a confluent of the Ganges, on the road to Bareilly. Here Walpole's brigade, to which he was now attached, stood fast for several days, preparing to force the passage of the river into Rohilkhand. "We have enough troops," he writes, "to eat up Rohilkhand; whether we (i.e., my regiment) partake of the 'finish' in Oudh or not, no one can pretend to foretell."

Meanwhile the plundering propensities of some of

1 Forbes-Mitchell's Reminiscences. 
his men were giving their commander "much occupation and annoyance." The raseals, he complains, "will not discriminate between an enemy's property, which is fair game, and that of the villagers and cultivators of the soil. I have several times been obliged to bring them up with a sharp hand to save myself from discredit. I sent three sowars to-day to the brigadier with evidence and proof enough to hang them, but he begged me to dispose of the matter summarily myself; but as I did not choose to be judge, jury, and hangman all in one, they saved their lives at the expense of their backs, though I believe the punishment was greater to me than to them, for I abhor flogging, and never resort to it but in the extremest cases. Still I must be obeyed by these wild hordes coûte que con̂te; and when reason and argument fail, they must learn that I will not weakly refrain from sterner measures. I am happy to find Sir Colin ready to back me à outrance, so as to maintain discipline."

"I had to go over to see the chief yesterday," he writes on January 19, "and did not return till night. I also saw good Colonel Seaton and Becher, who (the last) starts in a day or two for home and England."

"Our friend Colonel Seaton," he writes on the 23rd, "is to have command of a district to be formed of Aligarh, Fathigarh, Mainpuri, and the post at Miran-ke-Serai. It is a very honourable and important post; but he would prefer, and I for him, a more active command."

From Fathigarh on the 26th Hodson's Horse marched with Adrian Hope's brigade towards Shamsabad against a strong body of rebels who 
held the ford across the Ganges at Suraj Ghat. A sharp fight on the 27 th ended in the capture of all the enemy's guns, four in number, and the slaughter of 300 of their men.

Hodson himself, writing with a pencil in his left hand, thus describes his share in that day's fighting:-

"My usual fortune deserted me on the 27th at Shamsabad, for I got two sabre-cuts on my right arm, which have reduced me to this very sinister style of writing. We had a very stiff fight of it, as we were far in advance of the rest of the troops, and had to charge a very superior body of the mutineer cavalry; but there was nothing for it but fighting, as, had we not attacked them, they would have got in amongst our guns. We were only three officers and about 180 horsemen-my poor friend and second in command, M'Dowell, having received a mortal wound a few minutes before we charged. It was a terrible mêlée for some time, and we were most wonderfully preserved. However, we gave them a very proper thrashing, and killed their leaders. Two out of the three of us were wounded, and five of my men killed and eleven wounded, besides eleven horses. My horse had three sabre-cuts, and I got two, which I consider a rather unfair share. The commander-in-chief is very well satisfied, I hear, with the day's work, and is profusely civil and kind to me. . . .

"I hope to return to Umbâla when this war is over, to be refitted and get my men trained and drilled, which is very necessary. I do hope to be able to get home and see your dear faces once 
more as soon as our great task is accomplished. I want a change after twelve years of work, and I want to try what home and good treatment will do for my ankle, which is very bad; in fact, I am unable to walk a hundred yards without pain. Well, I think I have done pretty well with my left hand. They say I shall be well in six weeks. I say in ten days."

What griered him most was "the loss of poor Mac; he was invaluable to me as a brilliant soldier, a true friend, and thorough gentleman-I mourn as for a brother."

"My regiment," writes Sir Hugh Gough, who arrived with his squadron too late to share in the actual scrimmage, "came in for some very smart fighting, but with some sad results-in the death of Charlie M'Dowell, our second in command, who was killed by almost the first round-shot fired by the enemy, and in Hodson himself being severely wounded twice by sabre-cuts on his arm. My brother (Charles), I heard, had two narrow escapesone from a spent bullet which a rebel sowar had fired point-blank at him; the other from a spearwound, which a man was in the act of delivering when Hodson came up and disposed of his adversary. Altogether they appeared to have had a very rough mêlée, and I was much disappointed in being just too late." 1

On February 1 Sir Colin Campbell began lis march upon Lucknow by way of Cawnpore. It was not until three days later that Hodson found himself free to follow in the same direction. Seaton appears to have felt deeply the parting from his old ${ }^{2}$ Old Memories. 
comrades, and especially from Hodson himself. "All through the siege of Delhi we had shared the same tent, and there was something like a community of goods between us. When I was wounded he had tended me with anxious eare and kindness, and when under my command in the column he had served me with the devotion of a brother, ever ready to further my views to the utmost of his power, never sparing himself where duty was to be done. He was the very perfection of a commander of irregular cavalry -one of those men who, from sound judgment, high courage, strength of constitution, skill in the use of weapons, and intuitive knowledge of human nature, are fitted to be the eyes and ears of an army, or to plan and carry out a bold and dashing enterprise." 1

It was the last time that these two friends were to meet on this earth. On the 5th of February Hodson writes from Jalalabad, on the Grand Trunk Road to Cawnpore: "Nothing can be more favourable than the state of my wounds, and I have felt scarcely any inconvenience from travelling. I am fortunate in having Colonel Burn for a travelling companion-pleasant, intelligent, and warm-hearted. He drives me in his buggy, and we breakfast together al fresco. Fancy the Carabineers of poor Captain Wardlaw's squadron sending a deputation, headed by a sergeant, to say on the part of the men how grieved they were that I was hurt, and to express their hope that I should soon be well and in the field again. I confess these things are more gratifying to me than any mention in despatches."

1 From Cadet to Colonel. 
On the 9th Hodson reached Cawnpore, where he found time to foment his arm, which had become inflamed from the effects of his journey. On the loth Hodson's Horse crossed the Ganges and encamped at Unao with the leading brigades of Campbell's army. "Our friend [Napier]," he say's, " is ehief engineer with the force, and a brigadier to boot. I hope to see him in a day or two." During the halt at this place Hodson sent Hugh Gough back to Cawnpore to bring out arrears of pay for the regiment.

It was now that Gough made his first acquaintance with Colonel Robert Napier, to whom Hodson had given him a letter of introduction. That great soldier received him "with the kindness he never failed to show to me in all the years I knew him and served under him in after-life. . . . He was one of Hodson's greatest friends, and I have always considered this fact a strong proof of Hodson's acquittal of the serious charges brought against him. Napier would never have admitted an unworthy man to his frienckship." 1

Writing home to his sister on the 11th, Hodson tells her not to buoy herself up with the hope of honours for him. "I shall be a brevet-major, and nothing more, I expect. It seems the authorities here never sent home a list of men recommended for honours; and the home authorities have been waiting until they get one. 'Hine illæ laerymæ!' And we shall all suffer by the delay in more ways than one. But we are certainly to have prizemoney, and this with the batta will take us home this'time next year, if not sooner. . . . Dear, dear 1 Old Memories. 
home, sadly changed and contracted since I left it, but home still, and dearer than ever, since the dearest part of myself will accompany me. All old home memories were so vividly revived yesterday by Charles Harland's visit, and an extract he read me from a letter from his brother, describing the enthusiasm of the old people at Colwich [his father's old parish], when the news arrived that the King of Delhi was our prisoner, and how they came to inquire whether it was really their 'Master William' who had done it."

On the 12th he had begun to hold his pen once more in his right hand, and hopes to be again on horseback in a few days.

"The scar on my arm," he tells his wife, "is a very ugly one, and will mark me for life; but then, as I am not a lady to wear short sleeves, it does not signify. . . .

"It will be some days yet before the whole force is collected at Alambagh. Captain Peel has just gone by with his sailor's and their enormous ship guns, 68-pounders! I have little doubt but that Lucknow will be in our hands before another month is over; and theu I shall do my utmost to get my regiment sent back to Umbâla to be formed and drilled, which it wants badly. I only wonder it does as well as it has done. I could hardly take any other appointment, or even go home, until I had completed this task; and I like my regiment, and, what is even more to the purpose, the regiment likes me, and would follow me any and every where, I do believe."

The inflammation of which he had lately spoken turned out to be erysipelas. But "as it is," he 
writes on the 14 th, "I am actually nearer to a total eure than the men (Sikhs even) who were wounded the same day. My abstinence from spirit-drinking has stood me in good stead."

February 16 proved indeed for Hodson a redletter day. He had at last seen his friend Napier, who rode over with Sir Colin Campbell to the eamp at Unao. "He is looking better, but older, than when we parted; but his charming affectionate manner is as nice as ever. God bless him! I do love him dearly, as if he were indeed my boru brother. A note from him arrived while he was here: it had been three days going ten miles! Sir Colin was most kind and cordial, and prophesies I shall soon be lieutenant-colonel. I told him I feared there was small hope of that, unless my majority could be counted as for the Punjâb campaign, as Lord Dalhousie promised, but that it had not been put on record. He immediately said, 'Oh, I'll do that with the greatest pleasure. Let me have a memorandum of your services, and I'll do all I can for you.' They do say I shall have the Victoria Cross ; but I do not believe it."

On the 18th he rode over to Cawnpore to have "a big talk" with Napier. The big talk lasted for two days. On the 20th he returned to Unao, accompanied for part of the way by Colonels Napier and Lugard, the latter of whom had just been appointed to the command of a division as brigadier-general. By that time Hodson had learned that the delay in gazetting him as brevetmajor "was an accident, not owing to the home authorities. It has gone home now, and my name is in it, Sir Colin told me." 
On the morning of the 25th Hodson's Horse had arrived at Alambagh after a "terribly dusty" march of thirty-six miles. It was here, about five miles from Lucknow, that a strong British garrison, commanded by the noble Sir James Outram, had for three months past kept sleepless watch over the morements of many thousand armed mutineers, and had brilliantly baffled every attempt to circumvent, dislodge, or crush them by sheer weight of numbers. Hodson's officers had hardly time to swallow a cup of tea and a poached egg when the order came to turn out against a large body of rebels who were threatening the British flank and rear.

"This," says Sir Hugh Gough, "was my first day in action with Hodson's Horse as a complete regiment. . . When I say a regiment, I might almost call it a brigade, for by Hodson's influence and the magic power of his name recruits from the Punjâb had come flocking in, and I should say we were nearly a thousand strong. We were complete in officers, and altogether made a brave show as we advanced to our work." It was not long before great masses of the enemy were seen moving across our front-all of them mutineers, most of them infantry arrayed in uniform. "Our rapid approach," adds Gough, "had a great effect upon them. They seemed to make no effort to rally and stand, and as we advanced and charged we got well into them, and the whole affair seemed over. The rearmost gun was in our possession, and the enemy, as far as we had encountered them, in full flight."

At that moment, however, owing to the fierceness 
of the charge and pursuit, Hodson's Horse got out of hand and broke into scattered parties. The enemy rallied round their remaining gun, and poured grape and volleys of musketry into their disordered ranks. "Our men, gallant and forward in pursuit or a charge, conld not stand being hammered at a disadvantage. There was a din of shouting and noise, officers doing their best to bring the men up, but all to no effect, and it looked sadly probable that 'Hodson's Horse' would in their turn retreat.

"Hodson at this crisis managed to get a few brave spirits together- not more than a dozen. Well I remember him, with his arm in a sling from his wound at Shamsabad, shouting to the men to follow him as he made an attempt to charge." As Hodson and his adjutant were riding close together, followed by a few of their men, Hodson's charger, badly wounded, came down with him. At the next moment Gough's own horse reared straight up and fell dead. "The fire was most deadly. The range was short, and just suited to the point-blank fire from the smooth-bore musket under which we were exposed, so that nearly every one of our small party was killed or wounded. Fortunately I fell clear of my horse, and catching a sowar's whose rider had just been killed, I speedily mounted, and, as good luck would have it, was able to rally our men to a certain extent, who, seeing our supports coming up (7th Hussars and Military T'rain), now came on with a will, and charging the romaining gun, scattered the enemy in all directions."

While Hodson was still in search of another mount, Hugh Gough led his men in pursuit of 
the enemy to a village covered by trees and low jungle.

"In the ardour of pursuit," he writes, "I had got ahead of my men, when I came upon a couple of sepoys on their way to the village. They had their bayonets fixed, and seeing me unsupported, stood-one in my direct front, and the other on my right. I made for the former; but the one on the right took aim at me as I passed and shot me clean through the thigh, the bullet going through my saddle and my horse, killing her dead. Fortunately I fell clear, though helpless. My opponent was just coming up to finish me off when he was sabred by a trooper of the Military Train.

"The affair was now over. The enemy suffered severely, and were driven back into Lucknow; and we returned to camp, and I was much pleased to think that our men had retrieved their previous discomfiture. Their temporary 'funk' was really due to their having got out of hand after their first charge, and not having time to rally before they had again to face the enemy's heavy musketry-fire. The steadiest cavalry in the world might have found it difficult, and to an absolutely newly-raised regiment the position was a very trying one."

Hodson appears to have been greatly annoyed at the mishap to his brave young adjutant, the blame for which he imputed to some of his native officers. Taking them round to the dooly in which Gough was being carried back to camp, he soundly rated them for being the cause of Gough's wound. 
The wounded man, however, "gladly forgave them all, for they were really gallant fellows, and had shown their good qualities on many a former occasion." 1

Hodson himself had received a sword-cut in the leg, to which at the time he gave no heed, but which seems to have troubled him not a little during the next few days.

On the following day he had "a most pleasant interview" with Sir James Outram. "The brave old warrior greeted me most cordially, professing his satisfaction at having at last met one of whom he had heard so much, \&c., \&c. The pleasure was certainly mutual, for I have long wished to meet him. He made many inquiries about you also, and asked whether you had not been in the hills during the panic and helped the refugees, \&c. How proudly I could answer all his praise in the affirmative! Altogether this good old soldier's compliments were pleasing to me, particularly as he was not one of those who in my time of trouble passed me by on the other side."

Some days later, after the old chief's arrival at the front, Hodson refers to the great fuss which had arisen over the affair of the 25th. Sir Colin had taken just offence at a report that the cavalry had been led by Colonel —, an officer on his staff. "Sir Colin denounced Colonel —_'s 'leading' as 'an insufferable impertinence,' called me up, and asked me before them all, 'Were you present with your regiment on the 25th?' and on my saying 'Yes,' he cried out, 'Now, look here, look at my

1 Old Memories. 
friend Hodson here, does he look like a man that needs "leading"? Is that a man likely to want "leading"? I should like to see the fellow who'd presume to talk of "leading" that man!' pointing to me, and so forth. I nearly went into convulsions; it was such a scene!" 


\section{CHAP'TER XX.}

\section{LAST SCENE OF ALL. MARCH 1858.}

AlL through February 1858 Sir Colin Campbell had been maturing his plans for the final advance on Lucknow, and the reconquest of Oudh and Rohilkhand. From Calcutta, from Agra, from the Punjâb, rast stores of guns, ammunition, food, eattle, medicines, and other necessaries, with many reinforcements of Sikh and English troops, made their way to Cawnpore and other places where portions of the newly-formed army of Oudh lay waiting for the signal to advance. Not until the end of February did the commander-in-chief himself leave Cawnpore to take command of perhaps the finest army that ever in British uniform stepped out on Indian soil.

With the wariness of an old soldier bent on leaving nothing to chance, and patient of delays that fretted the souls of his subalterns and evoked impatient growls from onlookers stirred by the dashing feats of subordinate leaders, Sir Colin Campbell determined to hold his hand until he had brought together the means of crushing out all armed resistance by a ferw well-planted blows.

Hodson writes on the 1st of March: "Nothing 
of public importance is occurring. I am still unable to ride, so I do regimental work. I dined with Sir J. Outram last night. He would quite charm you, and were I not out of love with vanity, would spoil me; but I confess the respectful homage of the soldiers is pleasanter to my spirit than the praise of great men."

On the following day Sir Colin Campbell with a large part of his force marched past the Alambagh, and after a sharp skirmish, in which the enemy lost a gun, occupied the Dilkushâ, a large garden-house and park near the city, almost within range of the enemy's guns. Between Cawnpore and Lucknow were now assembled four strong divisions of infantry, two brigades of Sir Hope Grant's cavalry, three fine brigades of artillery, and one of engineers, making up an army of more than 20,000 men with 120 guns. Outram, of course, commanded the first infantry division, which included Neill's Madras Fusiliers, the 78th Highlanders, and Brasyer's Sikhs. The 93rd Highlanders and the 4th Punjâb Rifles formed part of the second division, commanded by General (afterwards Sir E.) Lugard.

Conspicuous among the regiments of Walpole's division were the 1st Bengal Fusiliers and the 2nd, or Green's, Punjâb Infantry. The war-worn 9th Lancers, Hodson's swarthy Horse, and the dashing volunteer cavalry, formed the pick of Hope Grant's powerful array. The Engineer Brigade might well be proud of such a leader as Robert Napier. In the list of battery commanders the names of Turner, Tombs, Olpherts, Remmington, Middleton, Bishop, recalled many a great deed done before Delhi, or on the road to Lucknow, 
by the soldiers of an arm renowned for matchless services in every field.

On the 4th Hodson had a long talk with Sir Colin at the Dilkushâ, whither his regiment had been ordered by mistake. He found his chief "even more than commonly kind and cordial." "I am not very well," he writes on the 5th. "This leg troubles me, and is the effect of the erysipelas which attacked my arm in consequence of the wounds closing too quickly. The truth is that I lost about a pound and a half of blood when I was wounded, and having had two slight bouts of fever since, I am not so strong as I would be: however, I am getting on, and am dosed with steel, quinine, and port wine ad lib. My arm is pretty well, but the wound opened again partially after the 25th, and I have been obliged to submit to bandages, \&c.; still I hope three or four days will set me all right again."

About this time he had the pleasure of meeting again his old Cambridge friend Osborn Wilkinson, then acting as deputy assistant quartermastergeneral to the Cavalry Brigade. Hodson was anxious about the health of his dear friend Napier, with whom he had breakfasted on the 4 th in the headquarters camp. "I grieved to see that he looked worn and troubled. I fear his health is very precarious."

On the morning of the 6th he moved his men from the Alambagh to a position nearer Lucknow and the Dilkushâ, Sir Hope Grant having placed him in charge of the line of communications with Jalâlabad, the Alambagh, and Sir Colin's camp. "So I had to bring my men up here, half way 
between the two camps, and to make arrangements for ensuring the safety of the roads and protecting the conroys, on which the existence of the army depends. The worst part of it is I cannot ride, and have had for the first time in my life to do outpost duty in a dog-cart! driving across country to post vedettes and pickets, \&c."

On the 8th he is over again in the chief's camp, looking for letters and hoping to see Napier. Failing in both quests, he goes on to breakfast and "a long chat with that pleasantest of persons, Sir Edward Lugard." While there he had a letter from Norman, then adjutant-general, to say that his stepson, Reginald Mitford, had been appointed to do duty with Hodson's Horse. "I can but think he is too young; but if he must see hard service so early, better with me than elsewhere. God grant it may be for his good. ${ }^{1}$ I am looking for the end with an eager longing for rest which I cannot control."

On March 9th he seeks to allay his wife's fears on his behalf by reminding her that "our force extends now round three sides nearly of Lucknowthe extreme right of our position, or rather camps, being at least nine miles from the left; so that engagements occur at one part which those at the other never perhaps hear of till next day! Indeed I have not been on horseback since the 25 th, as I am forced to save myself for emergencies. If anything important occurs, be sure I will send

1 "I never saw him again," writes General Mitford, "as the telegram from the adjutant-general appointing me to Hodson's Horse was followed next day by one from Mansfield (by order of Sir Colin) telling me of his death." 
a telegram somehow. I do hope Hugh Gough will soon be well; I do ill without such a dashing fine fellow.

"The Martinière was taken to-day without loss, except Captain Peel, who, I grieve to say, is wounded."

That evening he dined at the headquarters mess. Among those present was Mr (now Sir William) Russell, the famous war correspondent of the 'Times.' "Our camp dinner," he writes, "was very animated. . . Hodson dined with us at mess. A very remarkable fine fellow - a beau sabreur, and a man of great ability. His views, expressed in strong nervous language, delivered with fire and ease, are very decided; but he takes a military rather than a political view of the state of our relations with India. I should like to see Hodson at the head of his Horse try a bout with the best Cossacks of the Don or Black Sea; not that I would willingly have the fight, but that if it must be, I should be sorry to miss the sight of it." 1

On the morning of Narch 6 had begun the turning movement which the commander-in-chief had rightly entrusted to Sir James Outram, the stubborn defender of the Alambagh. While Sir Colin himself prepared to crash his way forward through a triple line of works, held by some 70,000 sepoys and armed retainers of the great landed chiefs and the titular Queen of Oudh, his trusty lieutenant was to press onward up the left bank of the Gumti, carrying or turning the enemy's defences and blocking their way of escape from that side of the great city.

I My Diary in India. Routledge, 1860. 
Three days later Outram had carried with ease the strong walled enclosure of the Pâdshah Bâgh or King's Garden, and proceeded to rake with his heavy guns the lines of works spreading southwards between him and the Martinière. On the same day, March 9, Sir Colin on his side sent Lugard's division against the first line of works in his front. Without firing a shot the Highlanders and Punjâbis of Hope's brigade stormed the defences of the Martinière, the college founded by a Frenchman in the days of Warren Hastings. Then with another determined rush they clomb up the lofty ramparts lining the canal; and that evening the line of the canal as far as Banks's House was safe in British hands.

The next day Lugard succeeded in storming Banks's House, and made his arrangements for marching to the left of the Kaisar Bâgh, while Outram was bringing his guns and mortars to play upon the same post from his camp across the river, and Hope Grant's cavalry were scouring the plain between the river and the old cantonments.

On the same day Hodson writes: "The mail is come with my majority. The brevet has given general dissatisfaction. Some of the double honours are marvellous; but it should be remembered that these promotions are given sponte sua by the home authorities, no recommendations having gone from hence till lately. I am content myself, having no interest. It proves they perceive I have done something, or I should not have this beginning; and it is satisfactory to find that it is universally considered that I have been shabbily used. Better this by far than to have people lifting up their eyes and saying I had got too much." 
"Immense progress," he adds, "was made yesterday, with not more loss than some eighteen or twenty wounded, and I hear to-day they are going ahead again. Pandy has quite given up fighting, except pot-shots under cover, and runs at the very sight of troops advancing. I stood on the top of the Dillzushâ palace yesterday, and watched the capture of as strong a position as men could wish for (which at Delhi would have cost us hundreds) without the enemy making a single struggle or firing a shot. . . . I expect to see Lucknow taken without being under fire again. Well, it must be confessed that I have had my share of the dangers of the war, and whether I receive honours or not, I have the testimony of my own conscience that I have done one man's work towards the restoration of our power in India.

"I have been occupied to-day in trying to get the Victoria Cross for the two Goughs. Hugh certainly ought to have it." 1

On the fateful March 11 Hodson addressed to his wife the last letter that she was ever to receive from her loyal and loving spouse. Before it reached Umbâla his days on earth were already numbered. The letter ran thus: "Just as I sit down to write comes an order to move our camp towards Alambagh again, Jang Bahâdur having at last arrived with his army and taken up ground between me and the enemy.... If anything occurs I will get Colonel Napier or Norman to send you a service telegram."

In the course of the same day occurred that last meeting between Hodson and Captain Osborn Wilkinson, of which the latter gives the following

${ }^{1}$ Both the brothers did receive the Victoria Cross. 
account: "I had been spending the greater part of an afternoon with him in his tent. His name and fame were on everybody's lips, and he had been recounting to me some of the stirring scenes in his romantic life. It seems to me now as if he must have had some prophetic warning that his end was near at hand, for he gave me several things as keepsakes, and at the termination of our interview, on my remarking that he must be looking forward to some respite from his labours, he solemnly replied, 'Yes, Wilkinson, I shall be glad of some rest.' We then parted, and not many hours afterwards he was summoned to his eternal rest." 1

About noon of the 11th Hodson's regiment was ordered to march at 4 P.M. to the camp of Brigadier Campbell beyond the Alambagh, leaving a squadron behind to co-operate with Jang Bahâdur. Meanwhile Hodson himself started off with two of his orderlies to the headquarters camp to learn how matters were going on within the city. "We were to wait for his return before marching," writes Dr Thomas Anderson, surgeon to Hodson's Horse. "The sore on his leg was then so nearly well that he could ride, but I asked him not to do so, but to drive to the Dilkushâ and there mount his horse, which was to be sent on to wait for him there. This he did, and sent back the dog-cart in which he had driven to the Dilkushâ. In the mean time we tiffed, struck our tents, and sent on our baggage, and were sitting under the shade of some trees waiting for his return. Captain Gough, who commanded, waited till 5 P.м., when he gave the order to march, as otherwise it would be dark before I The Gemini Generals. 
we could reach our new encamping-ground. As it was, it was dark before we reached it. Just as I dismounted, Hodson's orderly rode up to me telling me that his master had been dangerously hit, and had sent for me." 1

Soon after midday, having received his last orders from the commander-in-chief, Hodson walked into the tent of Captain (afterwards General) Hutchinson of the Engineers. "Where is Napier?" he asked of the friend whom he had not met since the Satlaj campaign. Hutchinson replied, "He is in the city, and will probably be taking the Begam Koti this afternoon." At Hutchinson's entreaty his visitor stayed to luncheon.

"I well recollect," writes his host, "the deeply interesting account I led him into of his hand-tohand conflicts. Noticing his large pistol (revolver), I asked him if he could trust it (it was a Colt I think), and told him how a revolver had twice failed me,-once in a cavalry charge with Forbes when the military police mutinied in Oudh in 1857, and once in a mine in Lucknow. He said No, the bullet does not always give sufficient shock to the system to stop a man, and mentioned one case in which though he had shot an assailant through the throat, yet he had after that a stiff sword-fight with him before he could kill him.

"He left me after luncheon to see Napier." 2

In a letter to Mrs Hodson, Napier tells us what happened then:-

"On the morning of our taking a range of palaces called the Begam Koti, I was reconnoitring the

1 MS. letter to Mrs Hodson.

2 MS. letter to the Rev. G. H. Hodson. 
breach whilst the guns were making it practicable, and waiting for the moment when I could send the word for the troops to advance, when your husband suddenly stood beside me and said laughingly, 'I am come to take care of you.' The signal was given for the troops to advance, and we watched their progress and entry into the building. All serious opposition soon ceased, and we followed through the breach into the palace. None of the enemy remained except a few parties shut up in houses, whom our troops were despatching. Your poor husband, Captain Taylor, ${ }^{1}$ and I were together then. I got separated from them in the crowd, and proceeded to push on our advantage. When I returned General Lugard told me that both your husband and Taylor were wounded, and that he was earnestly asking for me.

"I went immediately to Banks's house and found him in a dooly, not suffering much pain. His wound had been dressed, and he had all necessary attendance. I was obliged to leave him to go to the commander-in-chief, but then returned and remained with him till the approach of morning obliged me to return to my duties."

How Hodson came to meet the fatal bullet which cut short his brilliant career may best be told in the words of Mr Forbes-Mitchell, who had just borne his part in the storming of the Begam's palace :-

"By this time we were broken up in small parties in a series of separate fights all over the different detached buildings of the palace. Captain M'Donald being dead, the men who had been on

1 Now General Sir Alexander Taylor, K.C.B. 
picket with me joined a party under Lieutenant Sergison, and while breaking in the door of a room Mr Sergison was shot dead at my side, with several men. When we had partly broken in the door I saw that there was a large number of the enemy inside the room, well armed with swords and spears in addition to firearms of all sorts, and not wishing to be either killed myself or have more of the men who were with me killed, I divided my party, placing some at each side of the door to shoot every man who showed himself or attempted to rush out. I then sent two men back to the breach, where I knew Colonel Napier with his engineers was to be found, to get a few bags of gunpowder with slow-matches fixed to light and pitch into the room.

"Instead of finding Napier, the two men sent by me found the redoubtable Major Hodson, who had accompanied Napier as a volunteer in the storming of the palace. Hodson did not wait for the powderbags, but after showing the men where to go for them, came running up himself, sabre in hand. 'Where are the rebels?' he said. I pointed to the door of the room, and Hodson, shouting "Come on!' was about to rush in. I implored him not to do so, saying, 'It's certain death. Wait for the powder. I've sent men for powder-bags.' Hodson made a step forward, and I put out my hand to seize him by the shoulder to pull him out of the line of the doorway, when he fell back shot through the chest. He gasped out a few words, either 'Oh, my wife!' or, 'Oh, my mother!'-I cannot now rightly remember-but was immediately choked by blood. . . . I assisted to get him lifted into a 
dooly-by that time the bearers had got in, and were collecting the wounded who were unable to walk-and I sent him back to where the surgeons were, fully expecting that he would be dead before anything could be done for him."

"It will thus be seen," he adds, "that the assertion that Major Hodson was looting when he was killed is untrue. No looting had been commenced, not even by Jang Bahâdur's Gurkhas. That Major Hodson was killed through his own rashness cannot be denied; but for any one to say that he was looting is a cruel slander on one of the bravest of Englishmen." 1

It was already dark when a message from the death-stricken hero was brought to Dr Anderson by the faithful orderly Nihâl Singh, who had helped to place his beloved commander in the dooly that bore him to Banks's house.

"I started off at once," says Dr Anderson in the letter already quoted, "with an escort of sowars and the orderly as guide; and your husband's servants and light baggage and bedding followed on the mules. From the great distance, and the darkness of the night, and the difficulty in passing along an extended line of obstinate Gurkha sentries, I did not reach Banks's house, where your husband had been taken, till ten o'clock.

"I found him there on a dooly, with a doctor attending on him, and an orderly. He was perfectly sensible, but sleepy. He recognised me at once, and was delighted to see me, and made me sit down beside him and hold his hands. In a few minutes I relieved the doctor who had remained

1 Reminiscences of the Great Mutiny. 
with him, and made inquiries of him (the doctor) about the nature of the wound and the treatment that had been adopted. The wound was through the liver, the ball having entered between two of the false ribs in front and coming out between two of the same ribs behind, thus entirely avoiding the lungs. I found him very weak, but with a clear firm voice, but cold hands and feet, and suffering a good deal of pain. The pain was much relieved by firm pressure of the hands, and I accordingly sat down beside him, holding his right hand firmly in mine and attending to keeping his feet covered, and every now and then giving small doses of brandy-and-water as his pulse showed he required it."

About midnight Hodson fell asleep. At 1 A.M. on the 12th he woke up, and assured Dr Anderson that he felt much better. So thought his doctor also, for "the bleeding had ceased, his hands and feet were warm, his pulse good, and he suffered much less pain."

He had strength enough to give Dr Anderson a clear account of the circumstances which led to his receiving the fatal wound. He had gone on with the attacking column "as an amateur, but not leading or putting himself conspicuously in danger." The fighting was nearly all over when he and Nihâl Singh entered the courtyard in which some of the sepoys were still lurking. "I wonder if any one is in that room," he said to his orderly. On reaching the door two of the sepoys fired at him from inside. One of the balls struck him, causing for the moment great pain. He staggered back some paces before he fell. Nihâl Singh, he added, took him up in his 
arms and carried him towards a dooly which happened to be near at hand.

"He went on to tell me," says Dr Anderson, "that after he received the first shock of the wound he sent for Colonel Napier, and at once started off an orderly for me. Colonel Napier came at once and sent for Dr Clifford, who came and dressed the wound and left a doctor to watch until I arrived. It took about an hour to tell me all this, and afterwards he became drowsy, and continued half-waking half-sleeping until dawn, when he asked for tea. It was soon procured, and he drank two cups of it and felt very much refreshed. I thought him very much better then, and had hopes of his ultimate recovery provided bleeding did not return."

Unfortunately at 9 A.м. the bleeding returned, accompanied by much pain and increasing faintness. "He rapidly became worse, and at 10 A.M. I told him that there was no hope for him. I sent then for Colonel Napier, who came immediately, and I left them together for a quarter of an hour. He was able to talk, but only very feebly, as his breathing was much affected, and the anodyne remedies I administered had very little effect. Colonel Napier could remain merely a few minutes, as the commander-in-chief sent for him."

Before Napier returned to the side of his dying friend the dooly in which Hodson lay had been removed by $\mathrm{Dr}$ Anderson's orders into an empty room where quiet and privacy could be ensured.

Napier found him in much pain, and evidently weaker than on the previous visit, when Hodson had given him his last loving messages for his wife 
and family. "I feel that I am dying," were the words with which Hodson now greeted him, as the two men clasped hands once more. "I should like to have seen the end of the campaign, and to have returned to England to see my friends, but it has not been permitted. I trust I have done my duty."

"I could have no difficulty," says Napier, "in answering this question, as the voice of every one in the country proclaims it. . . I was grieved to leave him, but it was necessary for me to be at my post, and before I had time to return to him he had gone to his rest, calm and composed at his last hour as he was in the front of danger in battle. I took his ring, and Dr Anderson cut off his hair."

After Napier's departure, writes Dr Anderson, "he continued rapidly becoming weaker, though occasionally talking to me. At one o'clock I saw his end was rapidly approaching, and I asked him to say anything he wished. He said No, he had no message to any one, he had told Colonel Napier all his private affairs, but to send love to his wife and that his last thoughts were of her. 'These were his words."

"All this time," continues Dr. Anderson, "I was stooping by his bedside holding his right hand. He frequently grasped mine and, smiling, said, 'Oh, what pain!' I had my watch in my hand when he last spoke to me; it was a quarter-past one; it was a mere whisper, 'Oh God!' and in ten minutes more, at twenty-five minutes past one o'clock, the sad scene was over. He died most 
quietly, without a struggle; he merely ceased to breathe."

William Hodson died within a week of entering on his thirty-eighth year. The faithful Nihâl Singh wept long and bitterly over his master's body. Many of his troopers cried like children over their dead hero, whom they had loved and worshipped as their ideal of perfect soldiership, the model captain of light horse, the matchless swordsman, the wise yet daring counsellor, the born leader of men who would have followed him anywhither to the death.

On the morning of his death Captain Wilkinson was riding towards the camp of Hodson's Horse when he met one of the Gough brothers, who, "with tears streaming from his eyes," told him of their common loss. "He pointed out the place where he was lying, and on my hurrying there the doctors were engaged in examining his wound. . . As I mourn $\_$ully gazed on his poor lifeless form I could not l. slp contrasting 'the languor of the placid cheek' with the animation and energy and manly vigour that had lit up his handsome and refined features only a few brief hours before, when he was in the zenith of his renown." 1

On the evening of March 12 his body was buried in the garden of the Martinière, at the foot of a clump of bamboos. Conspicuous among those who stood beside the grave while the Rev. Dr H. Smith read the funeral service were the veteran commander-in-chief and all his staff. At the moment when his remains were lowered into the grave Sir 1 The Gemini Generals. 
Colin Campbell himself burst into tears over the loss of "one of the finest officers in the army"the man whom Robert Napier was proud to call friend, to whom Montgomery could find no equal for his rare combination of talent, courage, coolness, and unerring judgment. 


\section{CHAPTER XXI.}

\section{CONCLUSION.}

On the very next day, the 13th, Sir Colin Campbell, writing to the bereaved widow, gave frank expression to the sorrow felt throughout his army at her husband's death: "It is with a sentiment of profound regret that I am compelled to address you, for the purpose of communicating the sad news that your gallant and distinguished husband, Major Hodson, received a mortal wound from a bullet on the 11th instant. He unfortunately accompanied his friend Brigadier Napier, commanding Engineers, in the successful attack on the Begam's palace. The whole army, which admired his talents, his bravery, and his military skill, deplores his loss, and sympathises with you in your irreparable bereavement. I attended your husband's funeral yesterday erening in order to show what respect I could to the memory of one of the most brilliant officers under my command."

"Amidst universal sorrow and regret," wrote Napier himself to Mrs Hodson, "he was laid in his grave near the Martinière. I am going to enclose it with a masonry wall and build a tomb over it immediately. I grieve deeply now that 
I did not object to his entering the palace at all, but you know his forward spirit, and how impossible it was to keep him out of danger. It is God's will, and we must bow submissively."

"A finer or more gallant soldier," says Sir Hugh Gough, "never breathed. He had the true instincts of a leader of men; as a cavalry soldier he was perfection, a strong seat on horseback (though an ugly rider), a perfect swordsman, nerves like iron, and with a quick intelligent eye, indefatigable and zealous, and with great tact. He had the all-round qualities of a good soldier. Great was the grief in 'Hodson's Horse' at the death of their leader, for no man was more loved by his men. To me his death was a sad loss - he had been a kind friend to me from the day I joined him at Delhi. I had been longer with him than any of the surviving officers, and I knew him better than most." 1

Sir Thomas Seaton speaks of his friend's untimely death as "a calamity to our country, and I mourned for him as for a brother. I shall never see his equal." 2

In the letter from which I have already quoted Dr Anderson writes: "In closing this ungarnished account of your dear husband's last moments, allow me to tell you that we who have served with him through so many dangers felt his loss like that of a brother. $\mathrm{He}$ was the influence that kept us together, and since he has passed away from us we have all broken up, and another officer and I are the only two in the regiment that have served with him at all, and I am about to leave also. Had lie lived it would have been otherwise."

1 Old Memories.

2 From Cadet to Colonel. 
It is pleasant to note that even Sir John Lawrence officially pronounced him to be "one of the ablest, most active, and bravest soldiers who have fallen in the present war."

Many years afterwards, when Mr Forbes-Mitchell revisited the scene of those fierce struggles in which his regiment had borne so conspicuous a part, he saw himself once more standing by the grave of Major Hodson. "I found it," he says, "in excellent preservation, with a wall round it and an iron gate to it near the entrance to the Martinière College. This care had been taken of Hodson's last resting-place by his friend Lord Napier of Magdala, and I cut a branch from the cypress-tree planted at his head, and posted half of it to the address of his brother in England." 1

Immediately after Hodson's death a committee of adjustment proceeded in the usual fashion to examine and report upon his personal effects, which had been transferred to the quarters of Colonel Robert Napier. Captain (now Sir Charles) Gough, V.C., K.C.B., had been appointed president of the committee. The results of their proceedings showed that, with the exception of such memorials as a ring, watch, Bible and Prayer-book, and a miniature, which were handed over to the widow, "all Major Hodson's effects were sold by auction, and that the whole, exclusive of his horses, consisting of tents, a gig, camp equipage, guns (one rifle valued at £35), swords, telescope, saddles and bridles, \&c., realised the sum of Rs. 1774 , or less than $£ 170$. The only article found in his possession which could possibly have come under the head of 'loot' was a native

1 Reminiscences of the Great Mutiny. 
ornament of some flat stones set in silver, worth a few rupees at most, which had probably, as would appear from his letters, been bought from a sowar." 1 "The inventory of his effects," wrote Sir Charles Gough many years afterwards, in honest indignation at the revival of former calumnies, "bears witness to the fact he had no loot of any kind in his possession." 2

When the old scandal about the discovery of "vast stores of valuables" amongst Hodson's effects had been thoroughly exploded by Lord Napier and Sir Charles Gough, the slanderers of their dead friend and comrade affirmed that Hodson's trunks had been carefully rifled before they were examined by the committee of adjustment. The authors of this preposterous fable must have forgotten what both Sir

1 Hodson of Hodson's Hor'se.

2 "It was current in camp," writes Lord Roberts, who in common with the whole army had mourned his early death, "and the story has often been repeated, that Hodson was killed in the act of looting. This certainly was not the case. Hodson was sitting with Donald Stewart in the headquarters camp when the signal gun announced that the attack on the Begam Kothi was about to take place. Hodson immediately mounted his horse and rode off in the direction of the city. Stewart, who had been ordered by the commander-in-chief to accompany the troops, and send an early report to his Excellency of the result of the assault, had his horse ready, and followed Hodson so closely that he kept him in sight until within a short distance of the fighting, when Stewart stopped to speak to the officer in charge of Peel's guns, which had been covering the advance of the troops. This delayed Stewart for a few minutes only, and as he rode into the courtyard of the palace a Highland soldier handed him a pistol, saying, "This is your pistol, sir; but I thought you were carried away mortally wounded a short time ago.' Stewart at once conjectured that the man had mistaken him for Hodson. In face they were not much alike, but both were tall, well made, and fair, and native soldiers had frequently saluted one for the other. It is clear from this account that Hodson could not have been looting, as he was wounded almost as soon as he reached the palace." 
H. Daly and Sir C. Gough had stated at the time, that immediately on Hodson's death a guard had been placed over his effects until they were removed to the quarters of General Napier, who has declared that there was nothing in his boxes but what an officer might legitimately and honourably have in his possession.

It is amusing, though not a little sad, to mark the perverse ingenuity with which some of Hodson's detractors have twisted the most harmless incidents of his career into the clearest evidences of wrongdoing. We have seen, for instance, how the Cowhouse affair became transformed into an absurd fable of ill-gotten gains. Not long before his death Hodson had applied to the paymaster, Captain F. C. 'Tombs, for two months' pay for his regiment. General Mansfield, then chief of the staff to Sir Colin Campbell, had sanctioned the application. At Hodson's request the sum of Rs. 60,000 was paid to him in the shape of bills on Calcutta, for which at that time there was a great demand among the up-country bankers. "That they were duly paid," writes his brother, "all allow. ... It is perhaps needless after this to say that it can be proved that no such sum came into the hands of his bankers at Calcutta or was found by his executors."

Nevertheless, a story had been set on foot, and for aught I know is still current, to the effect that Hodson remitted to Calcutta a very large sum, amounting to some thousands of pounds.

With the arrears of pay and batta due to Hodson at the time of his death his executors were enabled to pay off all outstanding claims against his estate. "When this was done," writes the Rer. G. H. 
Hodson, "so little was left that his widow was obliged to apply to the Compassionate Fund for assistance, which was granted after due investigation by the Commissioners, of whom Sir Richard Temple was one, much to the surprise of those who had believed the stories that were circulated to his prejudice."

Shortly after his death Mrs Hodson asked the Rev. C. Sloggett to help her in looking over some of his private memoranda of accounts. "There was one in particular," says that gentleman, "a sort of debtor and creditor account against himself, drawn up, or supplied with its last entry, on the very morning of his being shot. After all that I had heard against him, I was astonished at the smallness of his resources. There was no larger balance than could be accounted for by his profit on the house at Umbâla and his good allowances as commanding a cavalry regiment." ${ }^{1}$

As honorary secretary to the Punjâb Special Fund, Mr Sloggett himself was able to assure the committee of management, consisting of the judicial and financial commissioners, $\operatorname{Mr}$ (now Sir Richard) 'Temple, Commissioner of Lahore, the eivil surgeon, and Mr H. C. Perkins, C.S., that the case of Mrs Hodson was "one which required their liberal consideration." The committee could not but accept the evidence thus supplied by an independent witness. So far, therefore, from having amassed a fortune by persistent plundering, it is absolutely certain that Hodson died without leaving his widow money enough to pay her passage home.

Besides the moderate pension to which Mrs 1 Rev. C. Sloggett's MS. letter. 
Hodson was entitled as the widow of a Company's officer, a special pension was bestowed upon her by the Secretary of State for India in Council "in testimony of the high sense entertained of the gallant and distinguished services of the late Brevet-Major W. S. R. Hodson." In further acknowledgment of those services Queen Victoria herself was graciously pleased to assign to Mrs Hodson a set of apartments in Hampton Court. After her death in 1885 the whole of her property was sworn by her executrix under $£ 400$. So much for the slanders that have dogged the memory of one of the finest soldiers whom England has ever sent forth to fight her battles on. Eastern ground!

After Hodson's death his regiment was attached to the Cavalry Division, and took part in the fruitless attempt to cut off the retreat of the mutineers from Lucknow. "Though its distinguished commandant was dead," writes Sir Hugh Gough, "the regiment continued to maintain its reputation under his successor, Colonel Daly (afterwards Sir Henry Daly, G.C.B.); did gallant service during the remainder of the Mutiny; was subsequently made into three regiments-1st, 2nd, and 3rd 'Hodson's Horse'; and finally, on the reorganisation of the native army, the 1st and 2nd regiments were renumbered and renamed 9th and 10th Bengal Lancers (both these regiments retaining the additional title of 'Hodson's Horse'), whilst the 3rd regiment was disbanded. I do not wish to be invidious, but I have no hesitation in saying that the 9th and 10th (Duke of Cambridge's Own) Bengal Lancers are quite among the pick of the Bengal cavalry of the present day-in each case 
mainly due to the Sikh and Punjâbi element they possess, the result of Hodson's great name and reputation amongst the natives of the Punjâb, whereby he secured the best and most warlike men to his standard." 1

Neanwhile a committee of eminent officers assembled at Calcutta in order to provide some lasting memorial of their glorious brother-in-arms. They decided that it should take the form of a monument in Lichfield Cathedral, which was afterwards erected from the designs of the late $\mathrm{Mr}$ G. E. Street, R.A. On this he is represented as receiving the sword of the King of Delhi.

"It will doubtless excite surprise," as Mr George H. Hodson naturally remarks, "that one whom the commander-in-chief pronounced 'one of the most brilliant soldiers under his command'-one whom all ranks of the army in India reckoned amongst their bravest and most skilful leadersone whom the popular voice has already enrolled amongst the heroes of the nation-one whose name was ' known, either in love or fear, by every native from Calcutta to Kabul,'-should have received during his life, with the exception of a brevet majority (to which he was entitled for services in 1849), no recognition of gallant services and deeds of daring, one-tenth part of which would have covered many of fortune's favourites with decorations." 2

That his services, however, were not forgotten or underrated by his countrymen at home may be seen from some of the tributes paid to his memory by the statesmen and writers of his day. On the 14th April 1859 both Houses of Parliament met to record
1 Old Memories.
2 Hodson of Hodson's Horse. 
a solemn vote of thanks to the Indian army. In the course of an eloquent speech on this occasion the Prime Minister, Lord Derby, made special reference to the two men by "whose premature death India, at all events, has sustained a most serious loss. I allude to two men, both of them models of chiefs of irregular forces, which they themselves had formed and disciplined from among tribes and natives who had not long before been our enemies, over whom by their valour, their rigid discipline, and at the same time by their careful attention to their real wants, comforts, desires, and even prejudices, they had obtained an influence which was all but marvellous, and which enabled them to lead their troops so formed and disciplined into any danger and into any conflict with as much confidence as if they had been British soldiers. One of these men has met a soldier's death, the other, unhappily, has succumbed under labours which were too great even for his vast powers; but it will be long before the people of India, I am sure it will be long before the Punjâb and Sind, will lose the memory of Hodson's Guides and Jacob's Horse."

In the House of Commons Lord Stanley, the new Minister for India, spoke of Major Hodson as one "who, in his short but brilliant military career, displayed every quality which an officer should possess. Nothing is more remarkable in glancing over the biography of Major Hodson that has just appeared, than the variety of services in which he was engaged. At one time he displayed his great personal courage and skill as a swordsman in conflict with Sikh fanaties; he was then transferred to the Civil Service, in which he performed his duties as 
though he had passed his whole life at the desk, afterwards recruiting and commanding the corps of Guides; and, lastly, taking part in the operations before Delhi, volunteering for every enterprise in which life could be hazarded or glory could be won. He crowded into the brief space of eleven eventful years the services and adventures of a long life. He died when his reward was assured, obtaining only that reward which he most coveted-the consciousness of duty done, and the assurance of enduring military renown."

"There was not a man before Delhi who did not know Hodson," remarked the writer of some excellent paper's in 'Blackwood's Magazine'; "always active, always cheery, it did one's heart good to look at his face when all felt how critical was our position. Ask any soldier who was the bravest man before Delhi, who most in the saddle, who foremost? and nine out of ten in the infantry will tell you Hodson, in the artillery as many will name Tombs.

"I once heard one of the Fusiliers say, "Whenever I sees Captain Hodson go out, I always prays for him, for he is sure to be in danger.' Yet it was not only in the field that Hodson was to be valued, his head was as active as his hand was strong, and I feel sure, when we who knew him heard of his death, not one but felt that there was a vacancy indeed in our ranks."

"Major Hodson," wrote the "Times,' "has been from the very beginning of this war fighting everywhere and against any odds wich all the spirit of a paladin of old. His most remarkable exploit, the capture of the King of Delhi and his two sons, 
astonished the world by its courage and coolness. Hodson was indeed a man who, from his romantic daring and his knowledge of the Asiatic character, was able to beat the natives at their own weapons. We could better have spared an older and more highly placed officer."

The impression which Hodson made upon those who knew him intimately may be gathered from the picture drawn of him by the lady from whom I have already quoted:-

"There was an indescribable charm of manner about him, combining all the gentle playfulness of the boy, the deep tenderness of the woman, and the vigorous decision of the soldier.

"His powers of attraction extended even to animals; and it was touching to see his large white Persian cat following him from room to room, eseaping from the caresses of others to nestle by him. I have often watched the pretty creature as he threw himself exhausted with the day's work on an easy-chair or sofa, rubbing himself against his master, whisking the long white tail against his fair moustache, and courting the endearments liberally bestowed. Restless with others, pussy was at rest if established by him.

"At Delhi there was a wild shy little kitten which fled from every one else, but mewed provokingly whenever he appeared-would jump on his knee with all the familiarity of an old friend.

"With his horses he had the same power of domestication. They yielded to the sound of his voice with the instinct that seemed to convey to all that in him they had found master and friend. . . . 
"His joyousness of nature made him the most charming companion. There was a certain quaintness of expression which gave zest to all he said; and yet there was a reverence, too, so that, were subjects graver than usual introduced even by allusion, they at once commanded his earnest response."

"I admired him," writes Sir Charles Gough, "for his gallantry in leading; his abounding energy, activity, and resource in difficulties; his coolness in danger; and his genial, cheerful, and kindly disposition." 1

Many years afterwards a distribution of prizes occurred at the Martinière College, near Hodson's last resting-place. A reference made by the Principal to Hodson of Hodson's Horse as the genius loci, and to the slanderous attacks made upon him, was followed by a speech from General M. Dillon, thus reported in a local newspaper: "As one who knew him in the field, and as one who was intimately associated for many years with the greatest soldier of the time, General Sir Robert Napier, now Lord Napier of Magdala, I am in a position not only to give my own opinion, but to state that General Napier was on the most intimate terms with Hodson during almost the whole of the career of that dashing soldier, and that he had the highest opinion of him. I have no hesitation in characterising the attacks that have been made, in the face too of the verdict of such a soldier as Lord Napier of Magdala, as ungenerous, unwarrantable, and atrocious." ${ }^{2}$

${ }^{1}$ Letter quoted in 'Blackwood's Magazine' for March 1899.

2 Hodson of Hodson's Horse. 
In a letter of October 1885 to General Mitford the same officer writes: "Lord Napier, who had known him in an administrative capacity and in the field, held him in the highest esteem, as did also Sir Henry Lawrence. We know what the army thought of him-I would that there were many like him to lead and set the example which he gave to us."

To the last Lord Napier of Magdala retained his old belief in Hodson's moral worth. Writing to his friend's biographer in November 1883, he says: "I am much obliged for the perusal of your preface to the new edition of your Memoir of your brother. I am now, as I have always been, fully convinced of his honour and integrity." To the same effect Sir James Outram, a man as shrewd as he was generous, had borne his testimony shortly after Hodson's death. "I was a great admirer of Hodson," he wrote to his brother, "and gave no credit to the stories against him."

Among Hodson's warmest admirers was the late George C. Barnes, who, as Commissioner of the CisSatlaj States, had done excellent service from the very outset of the Mutiny. Like many other of John Lawrence's men, he had been strongly prejudiced against Hodson by the stories current after Hodson's dismissal from the command of the Guides -stories founded, as we have seen, upon the virtual suppression of Reynell Taylor's report. His eyes had since been opened to the truth by $\mathrm{Mr}$ Sloggett's timely explanations, who had been invited to meet a large company of officers and civilians at his house.

"In the course of conversation," says Mr Sloggett, 
"having just opened at the table some letters brought in from Delhi, he said, 'So! Hodson has becn at his old tricks again.' I thought it only right to rise and ask for an explanation, and finding that all Mr Barnes had heard of and alluded to were those I have mentioned and one other I will presently explain, I told him and the others present about Reynell Taylor's report, which none of them had heard of; the purchase of the house at Umbâla, and the R.s. 10,000 charge.

"The fourth was as follows: Some two months before Delhi fell he was sent to destroy a small fort which was being armed against us by a native chief. On his way he met another hostile chief with an array of armed men, much outnumbering his own, whom he defeated after a sharp but short conflict. The chief himself was one of the first to fall, shot through the 'heart; and as Hodson returned after the pursuit, over the field, he saw something glitter on the ground and picked up a very beautiful and valuable jewelled ornament, a golden butterfly, soiled and dented by its fall upon the hard ground. This he brought and gave to his wife, who was fond of displaying it, with the dirt still adhering. Afterwards she wore it, and from this the story spread that it had been looted by him at Delhi, where I had seen it two months before the city fell, and knew, for I heard the story confirmed by others, the true account of its possession.

"After giving this explanation Mr Barnes thanked me very warmly, and set himself from that time to make Hodson's acquaintance, and this in such a friendly spirit that he came to be looked upon as one of his best and warmest friends. And not he 
only, but all the men I knew who got intimate with Hodson liked him, and did not believe the many stories to his prejudice-which by others, because of his very reputation, were too often carelessly repeated, and became, however unintentionally, magnified in the repetition. . . .

"And I can say this much, that there was nothing apparently mean or low about him. With all his faults and his arbitrary character, he was a high-minded man, fearlessly outspoken in his judgment of many who were only too likely to have his words brought back to them."

"His faults we have already seen," sums up the able writer in 'Blackwood's Magazine' for March 1899 ; "they were enumerated years before his death by his best friend, Henry Lawrence. But it was to his good points, just those so well set forth by his old subaltern, that he owed the lifelong friendship of such men as Robert Napier, Robert Montgomery, and Thomas Seaton; and to these characteristics too it was that he owed the love and the admiration of his men. As in the corps of Guides, so in his own regiment of Horse he was the object not only of respect but of veneration. To this day the few remaining of those who served under him, and the sons of those who served under him, speak of him by the title given him by the old King of Delhi-Hodson Sahib Bahâdur. His corps of Horse has long since been split up into the 9th and 10th regiments of Bengal Lancers, and the latter has been honoured by receiving the title of Duke of Cambridge's Own; but no matter how they may be officially known, or what titles may be given them,

${ }^{1}$ MS. letter from Rev. C. Sloggett. 


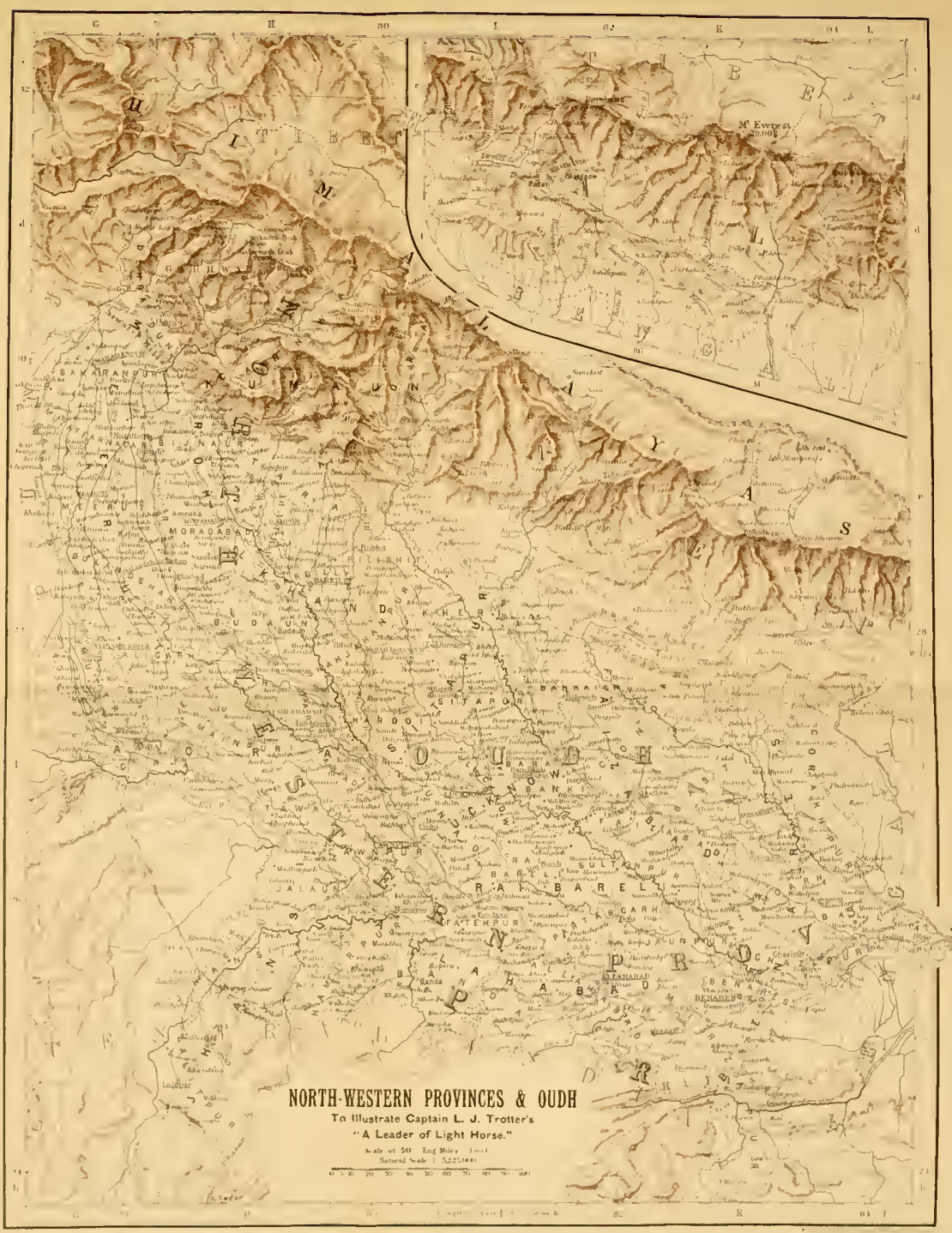



the name which they never forget, and which they most delight to honour, is that of Hodson's Horse."

What more remains to say concerning this great gifted soldier, who had gone through so many crowded hours of glorious life during those twelve years of Indian service, and had died, like his compeer Nicholson, at an age when few men have clearly learned how best to realise the promise of their youth? To such a question no answer need, I think, be given here. The impartial reader of this Memoir will at least be able to judge for himself how far I have failed or succeeded in clearing the fair fame of William Hodson from the obloquy which assailed it during his lifetime, and has continued to blacken and disfigure it ever since his death. 


\section{APPENDIX A.}

From Major Reynell G. Taylor, late Commandant of Guide Corps, to Major J. D. Macpherson, Mily. Secy. to Chief Commissioner, Lahore. Dated Jhelum, Feb. 13, 1856.

SIR,-In accordance with the instructions contained in your letter, No. 3369, of the 10th November, I have the honour to report, for the information of the Chief Commissioner, that the result of my examination of Lieutenant Hodson's accounts has been quite satisfactory.

2. The period embraced is from the 10th of March 1853 to the close of 1854. Lieutenant Hodson succeeded to the command of the Guide Corps at an earlier period than the first-named date; but at that time the accounts were kept by the adjutant, and Lieutenant Hodson first assumed direct management of the regimental accounts on the above date-namely, the 10th of March 1853-on which occasion he received a distinct balance in cash from Lieutenant Turner, and also an open statement showing the sums which he, Lieutenant Turner, believed to be claimable from the chest and due to it: this open statement I shall notice elsewhere.

3. Commencing with the cash balance received from Lieutenant Turner, the accounts were carried on as previously in a general day-book embracing all transactions, written for the first (13) thirteen months by Moonshee Nujjuf Allee, one of the regimental moonshees. As this man subsequently became Lieutenant Hodson's accuser, and strove to throw discredit on his own account, it is 
this period of (13) thirteen months that has required the most careful and sifting examination.

4. From the 4th of April 1854 to the close of the same year the day-book was kept by the other regimental moonshee, Goordeal, and as audited bills for (9) nine months 1853 and January 1854 were only received in February 1854 , and contained a large amount of retrenchments, which had to be gradually adjusted in the subsequent portion of the account, the examination of the records of the remaining (8) eight months could hardly be considered less important than that of the first (13) thirteen; but from the fact of the accounts having been kept in better form, with more collateral books of detail to support and explain them, their scrutiny was more rapidly accomplished.

5. Besides the above current accounts, Lieutenant Hodson, soon after taking command of the regiment, caused a transcript of the available Persian records to be made by one Moonshee Bachee Lall in the Hindi character. This transcript was set about with the express object of obtaining a more correct and detailed knowledge of all previous transactions than was furnished by the accounts which had been kepi first by Lieutenant Hawes (in English) and then by his successor, Lieutenant Turner (in Persian), which, though good records of the receipts and disbursements which had passed through the hands of those officers, were no evidence of the real financial state of the regiment, as they had never been balanced periodically, and when made over furnished no detail of the balance then in hand.

6. It was, then, in the hope of thoroughly clearing the account from end to end, and obtaining a detail of the balance for which he was liable, that Lieutenant Hodson set Moonshee Bachee Lall to work at his transcript of the accounts, and he first wrote out the cash-book kept by Subadâr Peer Buksh, then that by Munawar Allee rnder Lientenant Turner's supervision, then Nujjuf Allee's own, the transcript of which, after being brought up to date, was continued from day to day as a check. 
7. An attempt to complete a khata or balanced account from Peer Buksh's day-book failed, and that the main object of the original effort was unsuccessful is best evidenced by the fact of its not having been yet accomplished; and after Lieutenant Hodson, Lieutenant Godby, and myself have sat in voluntary committee on the accounts for some months, we are unable to give the details of a large portion of the balance of the chest at the close of 1854 , or say whether the money belongs to the former commandant, Major Lumsden, or to Government. The presumption is that to a great extent the former is the case, as that officer is known to have taken less than his due on many occasions. It amounts to this, that Lieutenant Hawes, on making over the accounts to Lieutenant Turner, took his receipt for an actual cash balance of about 4500 rupees, but did not or was unable to furnish him with any detail of it; and you will see that a similar sum remains in the chest as an undetailed balance after a general clearance of the accounts.

S. This was the nature of the account to which Lieutenant Hodson succeeded-everything known to be in the main correct, but the whole unbalanced and undetailed; and it must be recorded that he did not, on first obtaining command of the Guides, formally examine and take charge of the accounts. He had long been connected with the regiment, and knew all the difficulty and confusion that had been caused in its payment by a long period of ubiquitous service, during which its numerous; detachments had been paid by the various officers to whom they had been temporarily attached, causing a constant and most troublesome system of adjustment from the headquarters, which latter were also usually on the move, and the commanding officer obliged to take frequent advances from political or civil treasuries. He knew, from the character of the men that had been connected with the regiment, that everything, as I have said above, must be in the main sound and correct; and having just attained the chief object of his ambition, he felt no inclination to make objec- 
tion and clamour about a state of things which he knew to be, to a great extent, unavoidable, and to which his mind was accustomed.

9. I have tried to describe simply my own idea of the state of feeling under which Lieutenant Hodson omitted to do what was certainly his natural and obvious duty on the occasion of taking command. The omission, of course, rendered him materially responsible for all clear and ascertained claims that might arise; and the result was injurious to him, as it led to sums of money being spoken of as due by the chest, concerning which, from his vague and illdefined knowledge of the balance for which he was really answerable, he was unable to feel certain of his own liability until the whole accounts, from beginning to end, had been examined and balanced.

10. When Lieutenant Hodson did turn his attention to the accounts, he made considerable efforts to understand and make a clearance of them. I do not say but that these efforts might have been more determined and sustained, but the task was not an easy one, and Lieutenant Hodson believed that he would have leisure for its completion.

11. His own accounts meantime continued to be written in one general cash-book, which has proved to have been a correct record of all transactions; but unfortunately this was never balanced periodically, and hence the time and trouble occupied in finally adjusting his account.

12. And here I must remark that Lieutenant Hodson must be considered to have furnished a correct statement of all transactions during the period of his command, when he gave in an English translation of his cash-book in April last. He subsequently prepared a balanced account of the whole period from this cash-book, which was submitted to the Chief Commissioner, and finally sent to me for examination and verification. I caused its dissection, and examined the minutest details of every item, and found some errors and some necessity for rearrangement of the various heads of credit and debit; but this did not in the least affect the correctness of the original day-book, and the two must not 
be confounded. All the labour bestowed on the preparation of a balanced account has only had the effect of thoroughly testing the validity of the original book, and that I consider satisfactorily established. That the task of throwing the whole into the form of a balanced ledger, after a rigid scrutiny of all details, has cost time and trouble in unpractised hands, cannot affect its character as a true record.

13. It was for the correctness of the cash-book that Lieutenant Hodson vouched in his letter to you, No. 43, dated Peshawur, 21st of March 1855, as is clear froin the contents of paragraphs five and six of that letter; but I have good reason (not derived from Lieutenant Hodson himself) to believe that the voucher contained in the latter part of paragraph six above alluded to was subsequently supposed to apply to the summary statement of assets, liabilities, and balance for which you called on him, by the Chief Commissioner's directions, in your letter, No. 142, of the 4th of April 1855, and 151, of the 9th idem, and which being hastily compiled by the moonshees, and taken from the result of their work by Lieutenant Hodson, as stated in the second paragraph of his letter (No.62, dated Peshâwar, 11th of April 1855) forwarding it, proved in a great measure to be incorrect and useless. Should the above misconception have occurred, it may well have told most unfavourably for Lieutenant Hodson, as the appearance of the matter would be that he had promised to furnish an account which should stand any tesi, and subsequently submitted one which was in several points incorrect, and on being addressed by the deputy judge advocate-general on the subject, wrote back declaring that he had never vouched for its correctness.

14. You will know whether this game of cross-purposes really occurred: the probability of its having done so only became known to Lieutenant Hodson at the same time that it did to myself, as he was not present when the abovementioned abstract statement was examined by the court of inquiry. 
15. I shall here briefly enumerate the causes which led to doubt being cast upon the accounts. I believe them all but one to admit of satisfactory explanation by the accounts, and I therefore think it fair to Lieutenant Hodson to notice them in detail.

16. First, Lieutenant Turner, the adjutant of the regiment, expressed a belief that a duffadar, who had taken his discharge, had not been fairly treated concerning a horse purchased from him by Lieutenant Hodson; and further, that the Chunda fund of the regiment had suffered by the same transaction.

17. Secondly, Moonshee Nujjuf Allee asserted that Lieutenant Hodson had in August 1853 taken a large sumabout 3000 rupees-out of the regimental chest for his own purposes, when, from the fact of his pay having been retrenched in the pay-office, he had no funds to draw upon.

18. Thirdly, The same moonshee claimed a sum of (Company's rupees 270) Company's rupees two hundred and seventy as due to him by account from the chest, and also made two other claims on Lieutenant Hodson himself-one for (Company's rupees 65) Company's rupees sixty - five personal pay, and another for (Company's rupees 85) Company's rupees eighty-five on account of stationery, \&c., for the office.

19. Fourthly, The same man insinuated that Lieutenant Hodson had defrauded Government of the pay of deceased men, deserters, dismounted sowars, fines, \&c.

20. Fifthly, Moonshee Nujjuf Allee, when called upon to prove his chief allegation by his own accounts, declared that alterations had been made in the book since it left his hands.

21. Sixthly, Nujjuf Allee's cash-book alluded to proved, when examined before the court of inquiry, to be so full of erasures and corrections that it was pronounced unfit to be received as evidence.

22. Seventhly, It was supposed that there were not funds to cover certain considerable sums of money which it was known should be in the chest. 
23. Eighthly, At the time of the sitting of the court a number of claims were preferred by soldiers and others for sums of money due to them on various accounts, and other miscellaneous matters which appeared to bear unfavourably on the accounts were mentioned before the court of inquiry.

24. I shall notice these eight heads in order as briefly as I can, but it is not easy in a case like this to be concise and intelligible at the same time.

25. First, then, with regard to the case of Feroze Khan, duffadar, with the chief circumstances of which the Chief Commissioner is familiar, I need only report that I have carefully examined the various payments and repayments in the case, and believe them to be correct and true entries.

26. Thus Lieutenant Hodson was to give Feroze Khan, dufjadar, (Company's rupees 150) Company's rupees one hundred and fifty for his horse, or another of equal value.

27. On the 19 th of December Lieutenant Hodson advanced him (Company's rupees 150) one hundred and fifty from his private account when he was proceeding to Chuch to look for a horse.

28. On returning from Chuch unsuccessful Feroze Khan repaid this (Company's rupees 150) Company's rupees one hundred and fifty into the chest, and the sum, instead of being recredited to Lieutenant Hodson, was erroneously credited to Feroze Khan as a deposit.

29. On the 13th of January Lieutenant Hodson paid to Azadgul Khan, duffadar, (Company's rupees 200) Company's rupees two hundred from his private account for a horse purchased from him, and which had previously been made over to Feroze Khan in lieu of the 150-rupee horse taken from him.

30. Feroze Khan took his discharge from the 31st of January, and was paid up in full on the 3rd of March, at which time pay for January had not, however, been received. Lieutenant Hodson on this occasion repurchased the 200rupee horse for the regiment, and advanced the money 
himself, as the Chunda could not buy the horse till pay was received. At this time Feroze Khan received the original sum of 150 rupees standing incorrectly in his name as a deposit in the chest, and another 50 rupees made up as follows: 49 rupees paid to him by Lieutenant Hodson's own servant, and 1 rupee from his private account in the chest. It was the entry of this 49 rupees in a memorandum attached to the payment of 1 rupee on the 3rd of March which the Chief Commissioner drew my attention to as the only item, bad as the state of Nujjuf Allee's book was, that appeared to him really suspicious. I have, therefore, carefully examined this, as well as the previous entries, and though they are as irregular and out of rule as they can be, I cannot under the circumstances, and after having acquired a certain familiarity with Nujjuf Allee's style of book-keeping, regard any one of them as suspicious. The irregularity consists in the subjunction of explanatory notes; but as this appears to have been the moonshee's usual system, and as it is so very natural a one for a man whose natural calling was certainly not that of an accountant to pursue when his chief object was to keep a record that he should himself be able to understand, and when, in all probability, he may often not have fully understood the nature of a payment till some time after it had been made, that I cannot think that the fact of the entries being irregular and explained by notes invalidates their testimony.

31. In the case of the 49 rupees above noted, Lieutenant Hodson's recollection of the matter is, that when Feroze Khan was going he had to receive 200 rupees for the horse. The 150 rupees was paid him from deposit, and Lieutenant Hodson told an orderly whom he believed to have that amount of his in his charge to pay him the other 50 . This last sum, when counted by Feroze Khan, was found to be short by 1 rupee, which Lieutenant Hodson then ordered the moonshee to give him from his account in the chest. The payment of 1 rupee to Feroze Khan from Lieutenant Hodson's private account appears on the same day that 
Feroze Khan received his other balances; and to it is attached a note to the effect that Feroze Khan had really received 50 rupees, 49 of which had been paid by Lieutenant Hodson himself. Nujjuf Allee denied having added this note, but the natives who had condemned his book before the court decided that the handwriting of the note was certainly his.

32. It must be remembered that the duffadar who sold the 200-rupee horse given to Feroze Khan, and another duffadar who eventually received it after Feroze Khan's departure, are present with the regiment, while the whole circumstances of the case are known to so many that there is no room for the supposition that the truth has not been arrived at. Add to this that Feroze Khan himself, when questioned by the court, professed himself quite satisfied as far as his money dues were concerned; for I believe the root of the whole matter to have been that he had no mind to part with his original horse, and that he did not like the higher-priced horse given him in place of it half as well. It appears, however, that Lieutenant Hodson did give him opportunities of saying this if he wished it, but he did not avail himself of them, though perhaps at heart dissatisfied.

33. With regard to the idea that the Chunda fund had suffered by having to purchase a 200-rupee horse instead of a 150-rupee one, which without some explanation might have an injurious effect with those who have no exact knowledge of the working of a Chunda fund, I would put the case thus:-

34. Setting aside the case of a commanding officer, who had better have nothing to do with a transaction of the kind, suppose a subordinate officer to wish to purchase a horse from a sowar in the ranks, and to apply to his commanding officer for permission to do so, he would probably, if he obtained leave, be directed to be careful to give the man a full and fair price for the horse, or an equally good one in its place, would he not then be thought to have done the thing handsomely if he gave a 200-rupee horse in place of a 150 -rupee one? And would not the whole 
transaction be considered to have closed there as far as the subordinate officer was concerned? And if the sowar who had received the 200-rupee horse subsequently took his discharge, and the commanding officer resolved on purchasing the horse for the regiment, no injury would be done to the regimental fund; the lesser and the higher priced horse are both supposed to be worth their money, and each to have their respective value in the marliet, and the commanding officer may of course purchase any horse within the price fixed by Government that he thinks will be an acquisition to the regiment. I hope I have explained my meaning, and that the Chief Commissioner will agree in my view of the case.

35. Sccondly, Nujjuf Allee's chief allegation against Lieutenant Hodson-namely, that he had in August 1853 taken a large sum out of the chest, about 3000 rupees, and in the subsequent months of the year "hundreds of rupees," when, through a retrenchment in the pay-office, he had no funds to draw upon-must fall to the ground before the fact that, owing to the transfer of the regiment from the civil to the military department, so great delay took place in the audit of the pay abstracts of the regiment that a single statement, including eight months' pay of the regiment-namely, from April to November 1853-was only received from the pay-office in February 1854, and those of December 1853 and January 1854 were received a few days later in the same month, making the audit of ten months' pay received at the regiment all in one month.

36. The pay-bills for November and December 1852 and January 1853 were received subsequently even to the above-namely, in April 1854-from the civil anditor; so that the audit of thirteen months was received in the course of three months, though the whole of these months' pay was received in advances from the civil treasury at Peshâwar; and Lieutenant Hodson, like others, received the full amount of his pay, and Nujjuf Allee's own account shows that he never exceeded it. The retrenchment 
spoken of by the moonshee certainly occurred, but it dated from the 29th of August, when Lieutenant Hodson went on leave; and the pay statement and notice of retrenchment only having been received in February 1854, Lieutenant Hodson knew nothing about it till that date. His pay was only then held in abeyance for a confirmation of his leave.

37. With regard to the three sums claimed by Nujjuf Allee, two claims seem to have been grounded in truth and were settled. The third, for a sum of 270 rupees, would not, I think, be gained in a civil court; but were it so, the money would have to be recovered from Dr Lyell, to whom it has been paid, and to whom it appears to have been due by account.

38. Nujjuf Allee's fourth allegation sounds serious; but it amounts to this, that proper records of the estates of deceased men and deserters and of fines had not been kept up, so that the money received remained in the undefined balance of the chest, while dismounted sowars had, until orders were received for a different course, invariably received full pay. In both these instances all that can be said is that Lieutenant Hodson had failed to improve upon the hitherto prevailing custom of the regiment. It will be remembered that one of Feroze Khan's causes of discontent, mentioned by him to Moonshee Nujjuf Allee, was that he heard that he was to receive dismounted pay for the time he had been looking for a horse, which had not hitherto been the custom; as it was, I believe he was about the last that received full pay for the period during which he was dismounted under the old system. During Lieutenant Hodson's command the casualties were very few in number. While Nujjuf Allee was in charge of the accounts, (6) six casualties by decease and desertion occurred, and (7) seven instances of fines, some of which latter were remitted.

39. It is hardly necessary to notice the fifth point, as in the only instance in which Nujjuf Allee particularised an entry as not his own, the competent natives who had condemned his book before the court of inquiry decided dis- 
tinctly that the note appended was in his handwriting. In the original payment of 200 rupees for the horse purchased for Feroze Khan, where his repudiation of the note attached might have been of importance, Nujjuf Allee, when questioned by the court, allowed that the explanatory note was his, but asserted that Lieutenant Hodson had no funds of his own in the chest at the time-an assertion sufficiently answered by the refutation of his chief charge.

40. On the sixth head, if Nujjuf Allee's day-book be regarded as a regimental account liable to audit, I can say nothing in defence of it, as it is so cobbled and amended that it is wholly unfit for evidence; but it is an improvement on its predecessor kept by Subadâr Peer Buksh, which was seen by the members of the court of inquiry and impounded by them; and further, taken as a memorandum of all his transactions (which is, I believe, the true light in which it should be viewed), it is a good and welldetailed one, as is evidenced by its having been feasible to prepare a correct balanced account from it.

41. Besides his day-book, Nujjuf Allee also kept up nominal pay distribution rolls, written in his own hand with a steel pen: these have been, at the expense of some time and difficulty, compared with the scattered entries in the day-book and found to correspond throughout. In fact, I found no room for continuing a suspicion of the correctness of Nujjuf Allee's book, and it appears that when it suited him he himself appealed to it as unchallengeable; and further, its genuineness as a record is greatly established by the transcript made by Moonshee Bachee Lall, which was concluded before the period when Nujjuf Allee got into disgrace, of which fact Lieutenant Godby and myself have taken copious evidence.

42. On the seventh point has chiefly hinged the opinion at one time prevalent, that Lieutenant Hodson was a defaulter in account. It was known, in the first instance, that Lieutenant Lumsden had never made use of his command allowance, and therefore that the accumulations of it, amounting to a considerable sum, ought to be in the 
chest. Lieutenant Hodson had also received clothing compensation from the Government for the years 1852-53 and 1853-54, which would amount to Company's Rs. 4000, and yet from the appearance of things there was small hope of the assets of the chest being sufficient to meet these demands; the actual cash balance was very small, the outstanding assets were unknown, and Lieutenant Hodson, when naturally called upon to explain the state of things, conscious of the fact I have before stated, of his having no clearly defined knowledge of the nature of the balance he had received, could only reiterate the conviction, which he had always had, that all was correct and capable of eventual demonstration to be so; but with regard to the account prior to his command, that he could not say positively what sums there were available in the chest on this or that head until all had been sifted and examined from first to last. I confess I do not wonder at the fact of a tribunal of officers used to regular regimental accounts not being as sanguine as Lieutenant Hodson was about the ultimate solvency of the regimental chest; but the excuse I should be inclined to put forward for Lieutenant Hodson is, that under the circumstances of the case the account could not be viewed as a mere regimental one. Large sums had been advanced from the chest for a public work, and other difficulties had occurred so completely out of common course that common rules could scarcely be applied to them.

43. I have before noticed the open statement of recoverable assets and liabilities made over by Lieutenant Turner to Lieutenant Hodson on the 10th of March 1853: this did not profess to be an infallible sketch of the state of things, but an approximation; the result, however, has been that items to the amount of 1001 rupees, umnoticed in Lieutenant Turner's memorandum, were collected, while sums, amounting in all to Company's Rs. 2071, were disbursed in excess of what Lientenant Turner had believed to be due. Thus at the time of the sitting of the court any claims on Lieutenant Hodson, based on the supposed balance made over to him 
when he took up the management of the chest, would have been liable to considerable diminution; but when questioned by the court Lieutenant Hodson had only a general idea that something of the above nature had occurred. He was, however, conscious that he had made no direct disbursements from the various funds for which he was considered liable; and under these circumstances I can easily conceive that his replies appeared uncertain and unsatisfactory-a confidence expressed with apparently no demonstrable ground to support it.

44. The eighth point is the one I have alluded to as not admitting of perfectly satisfactory explanation. Claims on the chest appear to have been numerous, and though many of them were unimportant, and many others not claims at all, it is impossible to resist the impression that Lieutenant Hodson was in the habit of keeping men who had claims on the chest waiting a long time without examining their cases and clearing accounts with them. It is the prevailing impression which I cannot resist; for I cannot think the idea fully borne out by an examination of the cases contained in your letter, No. 188, of the 7 th of December, to the address of the major-general commanding the Peshâwar Division, and those mentioned before the court of inquiry. I have read through the whole of these cases, and wish to notice particularly the following heads:-

45. Out of (64) sixty-four cases in all that were brought to the notice of the court, I find that seven were claims for balances of half-mounting deductions; thirteen were on account of sums due either to individuals or Government, as estates of deceased or deserted men ; thirteen were cases of fines, civil and military; six of pay forfeited and due to Government; and, lastly, only nine were claims by individuals for arrears of current pay or deductions therefrom, which is the point to which I wish particularly to draw attention.

46. The cases of half-mounting balances were peculiar. Lieutenant Hodson stated before the court that with one exception the claimants had never made application to him 
for the money, and further, as the reason of this, that it had not been the custom to pay anything to the Pathans of the neighbouring districts or belonging to countries beyond our border, on account of previous deductions for half-mounting. I do not wish to leave the subject unnoticed, but I must allow that I have not carefully examined this point. I have, however, held conversations with Major Lumsden, Lieutenant Godby, and the pay jemadar on the subject, and the result is a belief that, as a rule, all classes were considered entitled to these balances, but that they were not unfrequently withheld if a man's character was bad, or if he had injured his arms, or asked for his discharge improperly.

47. With regard to estates, the system that had always prevailed in the regiment was that any sums accruing on such accounts were paid into the chest in ordinary course of account, and only paid out again on a clearly established claim by an heir; while all unclaimed sums, though considered to be entirely the property of Government, remained in the undefined balance of the chest. This, in fact, had been the mode in which all money due to Government had been treated in the regiment from the first, and it would have been right to have mentioned this when these cases, and those of forfeited pay, were brought to the notice of the Court.

48. Of the fine cases five were civil, inflicted in due course; three had never been inflicted; and five were military, and had been realised-two from bazaar-men and three from soldiers, if I remember right, from sowars who had brought their horses back from furlough in bad condition. At present, if this happens, a man is put on dismounted pay, which is much the same thing.

49. With regard to the whole number of cases mentioned, I may say that where Lieutenant Hodson's statements in reply refer to the accounts, they are borne out by the facts. Of scenes and events I have no knowledge.

50. But my particular business is with nine cases of claims, or asserted claims, for arrears of current pay or excess deductions therefrom. Of these, four were incorrect, 
and not eventually allowed; two were for sums retrenched in the pay-office; one case had been adjusted previously; in another the money was in deposit in the hands of a native officer; and the ninth was due, and had to be paid, but the claimant failed to prove that he had applied to Lieutenant Hodson for the money.

51. It must be remembered, at the same time, that Lieutenant Godby, who had, I believe, been called upon to ascertain all claims that existed against Lieutenant Hodson with the regiment, gave public notice that all who had them to make must speak then or be silent afterwards. It is certain, therefore, that every one who thought he had a chance of gaining by coming forward did so; and it is a very important point in the case, that it should be seen that there were no real complaints to be made on the score of pay.

52. With reference to this I must mention that Lieutenant Hodson had, under circumstances of really great difficulty, paid up the whole regiment to the end of October 1854, and cleared accounts with every man in it for all the advances that each had received while audit was pending. In doing this the following anomalous occurrence (when judged by ordinary rules) took place-namely, that he paid the regiment for the three months of May, June, and August with August's pay and half June's, aided by a large sum received as reaudits on former abstracts, and completed by a sum advanced from the chest.

53. I must put this in figures, for it will be hardly comprehensible or credible without them.

54. I must first mention that the deputy paymaster in several instances refunded the whole or a part of an abstract into the Peshâwar treasury on account of previous advances reccived for the corps, merely transmitting to the commanding officer the statement and retrenchment paper, by which he learned that whereas, in some former month, he had obtained a loan of Company's Rs. 17,000 from the civil treasury on his own idea of what what was due to the regiment, only Company's Rs. 15,000 had eventually been 
passed, and the balance had either to be recovered in arrears from the men or from the military auditor-general after correspondence and representation, while the abstracts passed for the current pay of the regiment were being refunded by the paymaster direct into the civil treasury in lieu of these former advances.

55. Received by the Guide chest :-

On the 19th June the audited pay abstract for May 1854 was received. Total passed after retrenchments, Rs. 15,637.

On the 25th of July the audited pay abstract for June was received. Total passed after retrenchments, Rs. $15,570.11 .11$.
This whole amount paid into the Peshâwar treasury direct by the deputy paymaster on account of former advances.

Of this Company's Rs. 7849.12.1 paid direct by the deputy paymaster into the Peshâwar treasury.

Balance available on the two months' abstract, Rs. 7720.15.10.

56. The above refunds were not to cover advances for the months for which the abstracts were passed, but on account of transactions of a long prior date. The audited abstract for April 1854, amounting to Company's rupees $20,613.15 .10$, had been in the same way paid direct into the Peshâwar treasury in lieu of advances of the former year; and the regiment being left entirely without pay, Lieutenant Hodson was obliged to get an advance of that sum again from the treasury, and it was to repay this advance for April, and an outstanding balance of former advances, that the above two sums were refunded direct into the Peshâwar treasury from the pay of the regiment for May and June, leaving Lieutenant Hodson half a month's pay with which to pay the regiment for the two months named.

\section{To continue.}

57. On the 22nd of August the audited pay abstract for July was received. Total passed after retrenchments, Company's rupees $17,582.5 .10$, and the money being received in full, was disbursed to the regiment-May and June still remaining unadjusted. 
On the 22nd of September audited abstract for August received in full Rs. 17,2S5 $\quad 8 \quad 3$

Also sums allowed in reaudit to the amount of . . . .

Pis. $30,314 \quad 5 \quad 10$

58. These reandits were the property of the chest, having been recovered after correspondence on account of sums which had been paid from the chest, but audit withheld for a time, while the whole of Lieutenant Hodson's debt to the Peshâwar civil treasury had been refunded indiscriminately from his passed abstracts.

59. This sum, therefore, was available to make good the deficiency in the months of May and June, from the abstracts of which only the balance before-mentioned remained available-namely, Company's rupees . . . . . . . . 7,7201510

Add August's pay and amount received in reaudits with it $30,314 \quad 5 \quad 10$

Total by abstracts . . . . . Ris. $38,035 \quad 5 \quad 8$ Add amount advanced from the

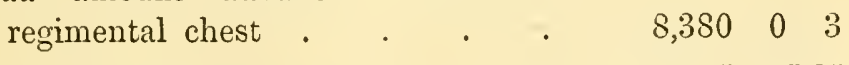

Total amount required to pay the regiment for May, June, and August . . . . . Ps. $46,415 \quad 5 \quad 11$

60. This above loan from the chest was chiefly composed of the pay of the European officers, and the whole was subsequently refunded by repayments on the fort account. Lieutenant Hodson had advanced about (Company's rupees 11,000) Company's rupees eleven thousand in all to the fort works, and eventually repaid it on receipt of assignments from the chief engineer; but a portion of the above sum, due as officers' pay, having been suddenly called for, he was obliged to obtain a loan from the banker of Major Chamberlain's corps for the immediate want, $-\mathrm{a}$ slight 
complication, which led to misconstruction in two instances.

61. The Company's rupees $46,415.5 .11$ was disbursed as follows :-

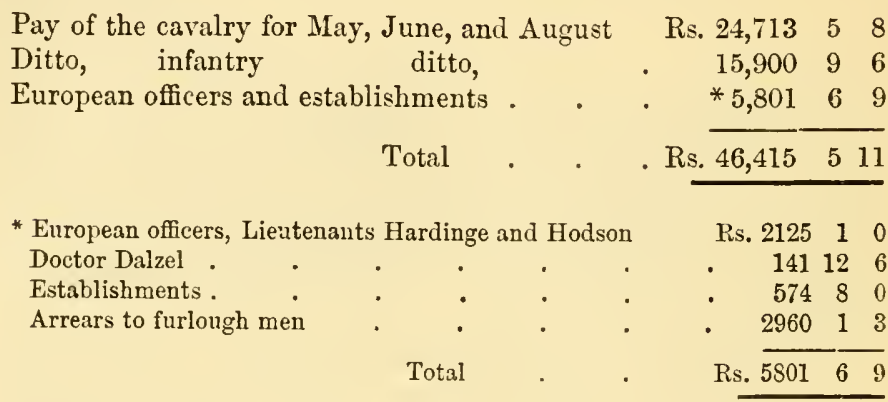

On the 21st of October audited abstracts for September were received in full and disbursed to the regiment. On the 18th of November those for October were received and disbursed.

62. I would draw attention to the dates on which these abstracts were received and audited in all the months I have mentioned, as they are good evidence that the monthly papers were made out and sent off regularly and without delay. During my command I have had difficulty in ensuring the receipt of pay in time to complete the disbursement of one month before the close of the following one.

63. Thus by the expedient above described, and by keep ing the men alive with petty advances, Lieutenant Hodson avoided the necessity of again applying for an advance from the civil treasury, which system, unavoidable under the circumstances, had caused such confusion and difficulty in his accounts; and on the disbursement of October's pay (which took place on the last days of November and the beginning of December) the whole pay accounts of the regiment had been put on a sound footing. The advances previously made as subsistence to the men had been recovered (a necessity which fell heavy on many that had 
forestalled their pay by advances begged from the chest), and the long outstanding difficulties connected with the pay of the regiment had been overcome.

64. It was almost immediately after this that a court was assembled to inquire into Lieutenant Hodson's conduct in the matter of Feroze Khan's horse, and he never rejoined his appointment; but he left the regiment paid up to date, and all the long-pending accounts of the men squared, and though complaints were, as I have before shown, invited, no valid ones were made on the score of current pay or excess deductions.

65 . With regard, then, to the outstanding claims against the chest which Lieutenant Hodson had failed to examine and clear off, it is I think, a fair presumption that as he had with careful endeavour surmounted his chief difficulty, he would eventually have adjusted all minor matters as well; and further, that as there were, as you will see by the balance-sheet, as many and as large sums due to the chest as claimable from it when Lieutenant Hodson's conduct became the subject of inquiry, placing the credits and debits of this nature in juxtaposition considerably softens the unfavourable aspect of the eighth point under notice.

66. I enclose the following papers, which will, I hope, fully explain the nature of the account and the mode of its final adjustment:-

(1) General summary of receipts and disbursements from the 10th of March 1853 to 31st December 1854.

(2) General balanced ledger of the above period.

(3) Statement of balance.

(4) Detail of ditto as far as known.

67. Such is the account. I may briefly sum up my opinion by saying that I believe it to be an honest and correct record from beginning to end. It has been irregularly kept, but every transaction, from the least to the greatest, has been noted in it, and is traceable to the individuals concerned; for it must be remembered that while we have been sitting in committee on the accounts at 
Murdan, nearly every man mentioned in the transactions of the chest has been present with the regiment, and throughout the inquiry I have found Lieutenant Hodson's statements borne out by the facts of the case, while in some instances where doubts had been engendered by a want of knowledge of details they were removed by working through the minutire of the account. At the same time, though the account was faithfully kept, it was not systematically checked; and you will see that several considerable mistakes and miscreditings remain to be corrected. Both Lieutenant Hodson and Dr Lyell have received overcredits in their private accounts which they have to make good, and two sums are found to be due to Major Lumsden and Lieutenant Miller; an item of error in account is due by Moonshee Nujjuf Allee, and several smaller sums due from Goverument on account of pay can only be recovered by special audit.

68. These are the skimmings of an irregular unchecked account of two years' standing. They argue want of system, and are only explicable on the grounds that inquiry broke in while adjustment was in progress; but, on the other hand, I do not for a moment regard them as suspicious, nor would the members of a court of inquiry view them as such, should one eventually be ordered for the examination of the accounts, when the adoption or amendment of this statement would probably form the basis of their report.

69. The explanation is, as I have before shown, that Lieutenant Hodson had only just emerged from his chief difficulty-namely, the confused state of the current pay of the regiment-when he became involved in other troubles which prevented his applying himself to a thorough balancing of the whole account, and without that no clearance could be effected. But this task would have required even from him a large portion of the labour and application which was eventually found necessary for it, though of course he (Lieutenant Hodson) could have taken large 
divisions of the account for granted as correct which we have been obliged to work through step by step; and I do not think it extraordinary that, engaged as he was in other duties, he did not manage to find time for this.

70. A natural course would have been for Lientenant Hodson to have made more use than he appears to have done of his natural assistants - namely, his subordinate officers; and I can answer for one who has been present with the regiment during the period of my command, having had every qualification to render him an efficient assistant; but with regard to this it is fair to mention that in the latter part of 1854 he was a good deal alone, Lieutenant Godby being on leave for several months in the autumn, and Lieutenant Turner having been attached, from July of that year I believe, to another corps.

71. Lieutenant Hodson had civil and political charge of Eusufzye, and had further the building of a large fort to superintend, and the two duties were calculated in a great measure to distract his attention from regimental matters; still I have shown that he certainly did not neglect them, and that the state of the regiment, as regarded the most important item of pay, was healthy, and supported by regular distribution rolls, \&c., while the collateral accounts of Chunda and clothing were fully kept, and had been the subject of care and labour. The accounts of the regiment were made over to Moonshee Goordeal in April 1854, and from that time the vernacular cash-book was kept accurately and clearly. A regular Chunda account, containing every necessary detail, had been kept up from July 1853. From April 1854 regular distribution rolls, containing full details of all deductions and the balance paid to each individual, were regularly kept; also vernacular copies of the pay abstracts with details of retrenchments and deductions in the pay office; also a separate debtor and creditor account, showing each soldier's trausactions with the chest, and the sum deducted from him on account of clothing, accoutrements, \&c. All these books have come 
greatly into employment in making out the account. A monthly balancing of the transaction of the cash-book would have kept all clear.

72. I should mention that where I have alluded to what occurred before the court of inquiry I have drawn my information from Lieutenant Hodson's transcript of the proceedings, which, I believe, he wrote down from the dictation of the deputy judge advocate-general. Any allusion of mine that appears incorrect can be immediately set right by reference to the original papers.

73. This statement has run to a great length; a short one would scarcely have matched the rest of the proceedings in the case. I am aware that I have in one instance noticed a matter (that of the horse purchased from Feroze Khan) which must have been fully examined and reported on by the court of inquiry. As the case, however, involved four entries in the books, the credibility of which it was the main part of my duty to ascertain and report upon, I do not think that there can be impropriety in my noticing it: I am quite unaware of the opinion given by the court on the subject, and therefore I cannot be supposed to be anxious to oppose or amend it. I merely give my own opinion on what has come under my notice, and if $I$ have entered into more details than was actually necessary, I am sure that the fact of Lieutenant Hodson's honesty and honour having been assailed with regard to this regimental account, and my examination of the case having convinced me that there was nothing wliatever in the accounts to afford grounds for the imputation, and, moreover, that he had had most unusual difficulties to contend with, will sufficiently account for my doing my best to show that I have demonstrable grounds for the opinion I have formed.

74. Lieutenant Godby, who assisted me throughout the laborious examination of the accounts with a wish to understand them himself and do Lieutenant Hodson every justice, appends a certificate to this statement to the effect 
that he is perfectly satisfied with regard to the correctness of the whole account.-I have the honour to be, sir, your most obedient servant,

Reynell G. TAYlor, Major,
Late Commandant Guide Corps.

True copy.

Reynell G. TAYlor, Major,

Deputy Commissioner.

From Major Reynell G. Taylor, late officiating Commandant Guide Corps, to Major H. B. Lumsden, Commandant Guide Corps. Dated Jhelum, 13th February 1856.

SIR,-In your demi-official letter of the 31st ultimo to my address you say that from your recollection of my report on Lieutenant Hodson's accounts, which I have read to you at Peshâwar, you think that the tenor of it will convey the impression that you had made over the accounts of the regiment to Lieutenant Hodson in such a state that all his subsequent difficulties were the natural result of it.

2. I take, therefore, this opportunity of saying distinctly that it is very far from my intention to convey the idea that you unfairly bequeathed labour and difficulty to your successor.

3. It is, indeed, very clearly my opinion that one of the chief causes of the difficulties which subsequently occurred was the undefined balance of the chest, which not having been clearly ascertained and set aside at first by Lieutenant Hodson, vitiated the whole of the subsequent accounts; but this view of the case does not affect you : the difficulties you had had to contend with were great and well known, and on leaving you left large balances, both public and private, in the chest, while you believe that all was then intelligible if Lieutenant Hodson had taken pains to master the difficulty at once. 
4. This he certainly did not do, as I have described in my report; and though you may be correct in your memory and belief, you must not quarrel with me if, as I have in the course of this inquiry encountered a good deal of inadequate appreciation of the difficulty of working up arrears of long-unchecked accounts, I still retain an opinion that the task of clear and rapid comprehension might have proved more difficult than you suppose.

5. But all that I wish to point out is, that the task of detailing the large balance of the chest was never accomplished. I have conversed with all the officers concerned, and none of them wished, or pretended to say, that it had been; still this would not have so much signified if Lieutenant Hodson had made strenuous efforts at once, on taking charge, to ascertain the exact amount of this balance, and had set it aside as a distinct item due by him. This he did not do, seeing no urgent necessity for it, and the money came and went as it was paid in or properly called for; and in the end he positively did not know the real sum he was liable for. It is not my intention to defend this, though perhaps carried away by my subject, and thinking of the far worse things that were laid to his charge, I have written warmly in my report as if there was nothing to be quarrelled with. I only contend that all was natural and explicable, and in a great measure brought on by circumstances.

6. There are many things, I am aware, that appear in Lieutenant Hodson's final balance-sheet which are utterly indefensible as matters of regular regimental account, and I have not wished to defend them. At the same time, I do not think it would be right or generous to condemn him for them under the circumstances of the case, considering the efforts he had made to clear the pay accounts, and the way in which he was brought to a sudden stop, after which the adjustment of any items would have been improper and suspicious. The fact of mistakes being worked out in an account by labour and careful examination is satisfactory 
proof of the honesty of the record, though sad evidence of its not having been carefully checked.

7. In forwarding the papers to the military secretary to the Chief Commissioner, I have noted all the items which are, I consider, irrecoverable or doubtful: they include those you allude to. The amount under both heads, however, will not exceed 250 rupees, and the bulk of the balance ought to be realised without difficulty.

8. Now I am going to say what you must know full well -namely, that the task that has employed me more or less during the whole time that I have been with the regiment has been a most uncomfortable one, as it has placed me to a certain extent in the position of a scrutiniser, and in a slight measure condemner, of the acts of men whose services to Government have been greater than my own. I hope I need not say that the duty would never have been entered into as fully as it has but for the hope of assisting a man whose case had been submitted to me, and whom I believe to be to a great extent a victim of circumstances, while I considered his honour clear in all that came under my notice.

9. The whole papers in Lieutenant Hodson's case go in to-day, and a copy of this letter accompanies them.-I have the honour to be, sir, your most obedient servant,

Reynell G. Taylor, Major, late officiating Commandant Guide Corps.

True copy.

Reynell G. Taylor, Major, Deputy Commissioner. 


\section{APPENDIX B.}

THE following correspondence seems to indicate the unkindly spirit in which Major H. Edwardes, the Commissioner of Peshâwar, took up the case of Khadir Khan against his alleged oppressor. It is evident from Hodson's answers to the questions put by Captain Cripps that the Pathân chief of Turu was not the sort of man whose word could be trusted in any dispute with an English officer.

No. 67 .

From Captain J. M. Cripps, A.C., to Lt. Hodson, late in civil eharge of Yusafzai. Dated Mardan, 2nd August 1855.

Sir,-Being at present engaged in investigating the claims of Khadir Khan of Turu to compensation for losses sustained by him to the extent of C. Rs. 15,151.7.3 (exclusive of some bonds for large sums of money) whilst in confinement at Peshâwar, I have to request the favour of being furnished with information on the following points :-

1st, At the time of confiscation of the Khan's property was any person placed in charge of his dwelling-house at Turu and the property contained within it; also, if a list of such property was prepared?

2nd, If any property was taken out of the small house situated within the enclosure around the Khan's estate, the door of which was nailed up?

3rd, If the attachment of the property took place in 
presence of any of the friends or relations of the Khan, and if so, who were they?

4 th, If the cash taken from the house of Shaikh Mian was counted in your presence; and was the Shaikh present at such time?

5th, Were any camels of the Khan's employed in conveying materials to the Fort, and if so, how many and at what rate of hire?

2nd, A few days subsequent to my arrival in Yusafzai I proceeded to Turu, and broke open the door of the small house alluded to in 2nd question. The only property discovered consisted of some shawls and choges much damaged by damp; but in one corner there was a large chest which had evidently been broken open, and the Khan states that in that chest were contained his most valuable jewels, none of which are forthcoming.

3rd, I shall be obliged for any information you can supply regarding the proceedings taken at the time of confiscation, to enable me to arrive at some decision regarding the justness or otherwise of the Khan's claims.-I have the honour to be, sir, your most obedient servant,

J. M. Cripps, A.C.

No. 106.

To Captain Cripps, Asst. Commissioner, Yusafzai. Dated Mardan, Sept. 4th, 1855.

Sin,-I regret that I have been unable to reply earlier to your letter, No. 67, dated 2nd ulto.

I reply to your questions in the order in which they occur.

1st, Khadir Khan's property was not "confiscated" on his arrest. It was attached by my orders, with a view to its safety. His house, cattle, and horses were left in charge of his own family. The acting thanadar of Mardan, Rahmat Ali, was placed with 4 barkandazes at the exterior gateway 
of Khadir Khan's house to prevent any of the live stock or horses or other property being taken away. As far as I recollect, a list of the live stock was made out. This, I conclude, will be among the vernacular file of papers connected with the proceedings.

2ndly, The property contained in the chest in the small house alluded to in your -2nd question and 2nd paragraph was opened in my presence, and the property it contained (consisting of ornaments, a few jewels, and gold and silver trinkets) taken out before me. The whole (together with some books and papers) was taken by me to camp and placed in a box (secured by a letter-lock which could be opened by no one but myself) under the guard at my tents. A detailed list of the contents was made out in my presence and carefully compared by myself, and eventually the whole was handed over by me personally after a strict comparison with the list. This list is, or was, on the file. Thus I am in a position to state with confidence that the whole property so recorded was produced and made over. Wherefore, supposing that the property detailed in the list referred to was restored to Khadir Khan, his statement as to the contents of the chest not being forthcoming must be entirely false.

3rdly, The Khan's brother and son and several of his people were present when the search above mentioned took place, and when the property was removed. The son himself handed over to me some of the books and papers.

4 thly, The cash taken from the house of Shaik Mian was not counted in my presence, but at the tahsil.

5 thly, Some camels of Khadir Khan's were employed on the public works. They were fed, the sowars employed on them were paid regular wages, and pack-saddles, \&c., made up and repaired for them. All such sums were paid out of public works account and charged in my bills. At this distance of time I cannot state numbers or rates from memory. The female and young camels and those unfit for work were left with the family.

2. With regard to your last par., I shall be glad to give 
you information on any point in my power. The attachment was conducted by myself personally to ensure no injury being done or annoyance given to the women of the family. There was scarcely any property of any kind in the place save horses, cattle, and corn, none of which were removed, with the single exception of the contents of the chest already alluded to. If these have been made over to the Khan, together with the live stock, I should unhesitatingly say that he can have suffered no loss of any property which was visible on his estate at the time of the attachment. - I have, \&c., 


\section{APPENDIX C.}

IN his 'Recollections of a Highland Subaltern' (E. Arnold, 1898), Lieut.-Colonel W. Gordon-Alexander gives the following trustworthy account of what happened just after the storming of the Begam's Palace:-

"As I turned round again towards the breach, I noticed two officers, whom I took to be on the staff, clambering over it, and when they reached the bottom on the inside, proceed arm-in-arm to skirt the wall of the platform on which the mosque stood, and, merely glancing at the firing going on in our corner, make for the passage or lane which led to their right. Believing that this lane was bordered by rooms harbouring desperate fellows in concealment, similar to those at the gateway we were then dealing with, I called to a man of my company below to run towards these two officers, one of whom I had just recognised as Hodson of Hodson's Horse, and warn them to be careful. As I was descending the ladder to terra firma a tremendous explosion made me pause and turn round, to witness what was evidently the explosion of the large mine at the breach where the right wing had entered. . . .

"The man I had sent across the court to warn Hodson was the 'funny man' of No. 6 company, called John Dougherty, a Glasgow Irishman. . . . As there was no further need for me in that corner, and my men of No. 6 company were only hanging about waiting for the sepoys penned into the gateway ( $B$ in plan) to be blown up, I called out to them, when I had descended the ladder, to follow me, and doubled across the courtyard after Hodson and his friend. Dougherty, unfortunately, did not catch 


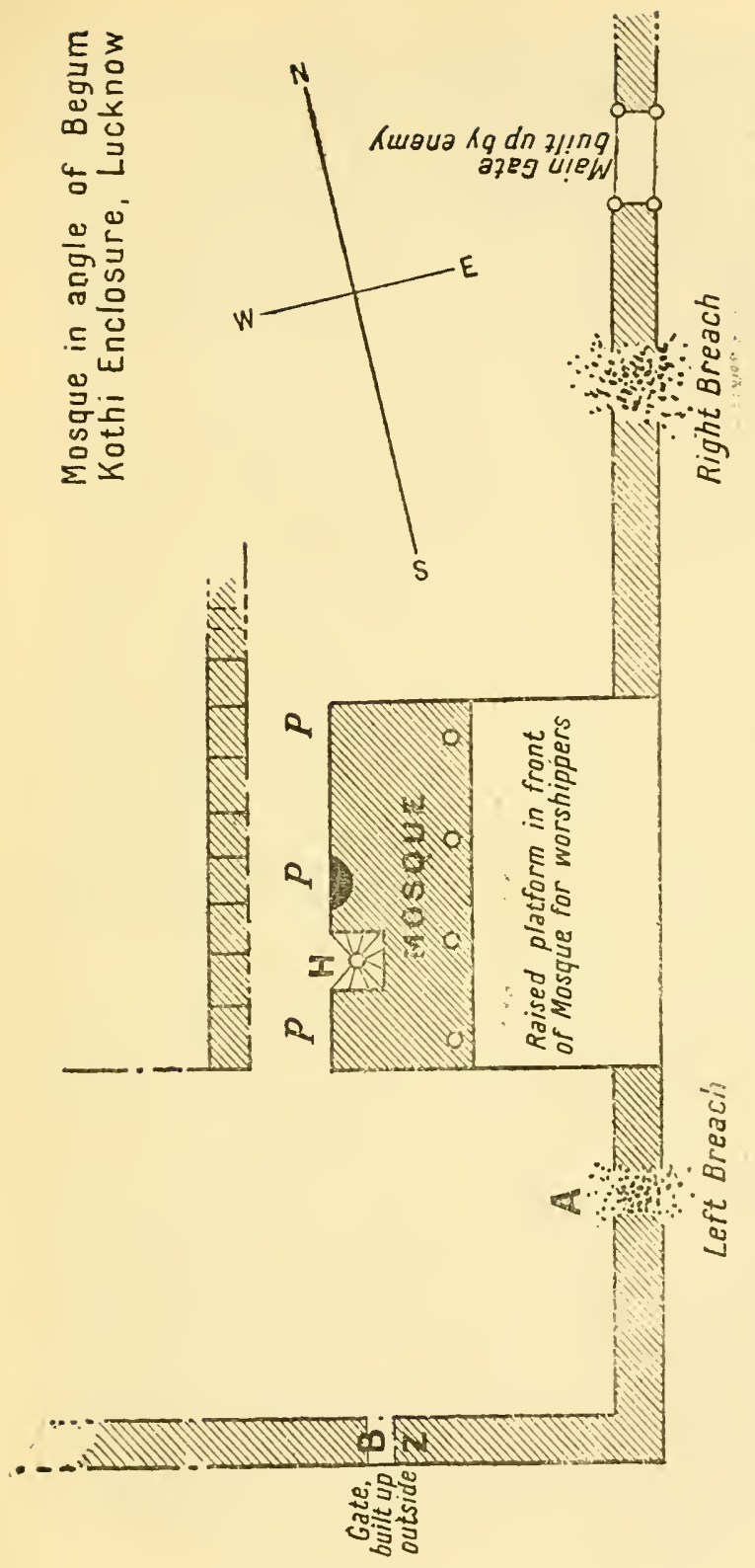

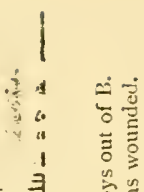

E

E录范

E $习$ . 
them up, and before they had gone many yards down the passage $(P P P)$ which ran along out of our square at the back of the mosque, Hodson turned into the first doorway he came to on his right (the only doorway on that side of the passage), which opened into the foot of a narrow short staircase (marked $\mathrm{H}$ on the plan) leading up into the mosque above. Immediately one or two shots were fired, and Hodson staggered back. Dougherty never stopped, but ran in to the door and pinned the man who shot Hodson with his bayonet before he had time to reload. ${ }^{1}$ There was only one other sepoy in the doorway, and he was bayoneted too; and when they were both hauled out into the roadway I noticed the stair, up which

1 Colonel Malleson, at p. 271 of his fourth volume, thus records Hodson's death: "He had joined the storming-party, had entered the breach with Robert Napier, and had bcen separated from him in the mêlée. $\mathrm{He}$ was not wounded during the storm; but after the breach had been gained, he rushed forward to seek for sepoys who might be concealed in the dark rooms and recesses of the palace." I must here draw attention to the facts, which I can personally vouch for and have recorded in the text, which traverse all the statements put by me in italics in the above quotatiou. Major Hodson did not join our storming-party, and could not have found any position in it if he had; he was in no mêlée, but walked in quietly arm-in-arm with his friend, Brigadier Napier, over the left breach, and therefore "rushed" nowhere.

As Colonel Malleson has recorded in his History his own opinion that the execution by Hodson himself of the "princes of the House of Taimur" was "needless slaughter," I here venture to assert that he would not have found two men amongst the magnificent lieroes of the Delhi besieging force, not three among Sir Colin Campbell's relief and siege of Lucknow force in 1857 and 1858, who would have agreed with him.

As to the unsupported assertion by the author of 'The Life of Lord Lawrence,' Professor Bosworth Smith, that Hodson was "killed in the act of looting in a louse in Lucknow," Mr Smith never answered either my challenge, published in the 'St James's Gazette' and dated May 23, 1883, nor the challenges of other eyewitnesses of Hodson's death which appeared in other London newspapers, including the 'Daily News,' about the same time, denying the base accusation-challenges which certainly called for the production of the evidence upon which such a charge could be based by Mr Smith; or, failing that, for an ample apology for having ventured to make such a charge. Mr Smith ought not only to have admitted that he had been misinformed, but to have apologised for propagating such a slander. He did neither. 
two more of my men mounted step by step, prodding with their bayonets above them till they ascertained there were no more Pandies in hiding there.

"When I re-emerged from the staircase Hodson had been borne away, and his friend, who, I afterwards heard, was our chief engineer, Brigadier Robert Napier, had also disappeared." 


\section{APPENDIX D.}

The following verses by Sir Mortimer Durand, K.C.S.I., appeared in an Indian newspaper shortly after Hodson's death. They have since been quoted by Mr David Ross in his 'Land of the Five Rivers and Sindh.' They are supposed to represent the feelings of an old Sikh warrior, Attar Singh :-

"I rode to Delhi with Hodson : there were three of my father's sons; Two of them died at the foot of the Ridge, in the line of the Mori's guns.

$I$ followed him on when the great town fell ; he was cruel and cold, they said :

The men were sobbing around me the day that I saw him dead.

It is not soft words that a soldier wants; we know what he was in fight ;

And we love the man that can lead us, ay, though his face be white.

And when the time shall come, sahib, as come full well it may, When all things are not fair and bright, as all things seem to-day, When foes are rising round you fast, and friends are few and cold, And half a yard of trusty steel is worth a prince's gold, Remember Hodson trusted us, and trust the old blood too, And as we followed him-to death—our sons will follow you." 


\section{N D E X.}

Abbott, Major James, 77, 92, 134, Bhôts, the, 115, 116.

150.

Agnew, Mr Vans, 65, 66.

Agra, 21, 130, 284, 285.

Alambagh, 318.

Aligarh, 292.

Alipur, 201, 202.

Ali Reza Khan, 237.

Aliwâl, 31.

Amritsar, 95, 107, 112, 123.

Anderson, Dr, 269, 330, 334 et seq., 341 .

Birch, Colonel, 169.

Biyas, the, $\$ 1$.

'Blackwood's Magazine' quoted, $160,168,170,198,249,274$, 349,354 .

Bohar, 241.

Boileau, Brigadier, 142, 144.

Bolundshur, 278.

Bori Afridis, campaign against, 142 et seq.

Bowring, Mr Lewin, 96, 130.

Anderson murdered at Multân, 67. Bradshaw, Colonel, 127.

Anson, General, 185 et seq., 190, Broadfoot, Major, 36. $191,196,197,285$.

Arnold, Dr, 3, S, 110.

Arnold, Mr Thomas, 'Passages from a Wandering Life' quoted, $8,120$.

Burn, Colonel, 314.

Butler, —, 225.

Calcutta, 20, 125 et seq.

Cambridge, 15.

Arnold, Mr William D., 106, 107. Campbell, Sir Colin, 84, 277, 289,

Attock, 93.

Babar Khan, 242.

Baddi-Pind, 88 et seq.

Badli Serai, 202, 204.

Bahâdur Shah, capture by Hodson of, 264 et seq.

Bahâwal Khân, 72.

Bareilly, 40.

$300,302,303,308,311,313$, $317,321,323$ et seq., 339, 340.

Canning, Lord, 169, 187, 188, 190.

Cave-Browne, Rev. J., 235.

Cawnpore, 228, 236, 315, 317, 323.

Chakar river, 64 .

Chamberlain, General Crawford, 248.

Barnard, Sir Henry, 197, 199, 201, Chamberlain, Sir Neville, 135, 208, 209, 214, 219 et seq.

Barnes, Mr George C., 352, 353.

Bashârat Ali, 239, 248, 249.

Battye, Quintin, 207, 208. $216,224,226$ et seq., 237, 246, 261.

Champain, - 211.

Chance, Mr G., 16.

Becher, Colonel, 65, 207, 214, 292, 311.

Bhagpat, 218, 219.

Bhairowal, treaty of, 50 .

Chatar Singh, 78 n., 80, 92.

Chesney, - 209.

Chester, Colonel, 1S6, 187, 189, 190, 203, 204. 
Chibramau, 301, 304, 306.

Chinâb river, $83,91,97$.

Clifford, Dr, 336.

Cocks, Alfred, 293.

Coke, Major, 220.

Congreve, Colonel, 292.

Cotton, Bishop, 9.

Cotton, Sir Sychey, 173.

Courtenay, Mr, 151.

Court of inquiry into charges against Hodson appointed, 157 -delay in assembling, 158method of collecting evidence, 159 et seq. 一the inquiry, 161papers returned by the Judge Advocate-General, 163-court reassembles, $i b$. - its report, $i b$. - Major Reynell Taylor directed to examine Hodson's accounts, 164 -his detailed report acquitting Hodson, 166 et seq.--further public inquiry disallowed by authorities, $16 S$ et seq.

Craigie, Colonel Halkett, C.B., $161,163,172$.

Cureton, Brigadier-General, 83.

Currie, Sir Frederick, 21, 50, 65 et seq., 71, 74, 84, 89, 130.

Curzon, Colonel, 186.

Custance, Colonel, 284.

Dâdri, $2 S 4$.

Dagshai, 174, 184, 188, 191.

Dalhousie, Lord, 73, 74, 91, 99, $105,121,126,139,143,149$, $151,156$.

Daly, Sir Henry, 206, 214, 218, $344,346$.

Daniell, - 224.

De Brett, - 224 .

Delhi, 22 - seized by the mutineers, 191-198 - plan for carrying the city, 209-the scheme breaks through, 211 - storming of Delhi, 256 et seq.-Hodson captures the King, 264 et seq.- seizes and executes the Princes, 267-275256.

Derby, Lord, 348.

Dhulip Singh, 25, 35-mother of, $35,69,73$.

Dick, Sir R., 32.

Dillon, General M., 351 .
Dinanagar, 62, 64, 75, 84, 95 .

Douglas, Captain, 124.

Durand, Sir Mortimer, K.C.S.I., 389.

Edmonstone, Mr G., 122, 126, 133.

Edwardes, Sir Herbert, 48, 61, 68, $71,74,77,96,141,149,156$, 160,382 .

Eld, Major, 299.

Elliot, Sir Henry, 91.

Fathigarh, 307, 308, 310.

Fathi Khan, 96, 153, 154.

Ferozepore, 26.

Firozshah, 27, 29.

Fisher, Major, 83.

Forbes-Mitchell's 'Reminiscences of the Great Mutiny' quoted, 303, 309, 332 et seq., 342.

Forrest's 'Selections from the Records of the Indian Mutiny' quoted, 214, 24S, 259, 271.

Foster, Riev. F. A., 13, 37, 50, 53, $114,120,132,178$.

Gangêri, 293.

Geneste, - 205.

Gilbert, Sir Walter, 26, 32, 39, 43, $99,105$.

Gilgit, 114.

Godby, Lieut., 144, 145, 155, $156,158,161,163,165,167$.

Gomm, Sir William, 130, 144, $168,169,183$.

Gordon-Alexander, Lieut.-Colonel W., quotation from 'Recollections of a Highland Subaltern' by, 386 et seq.

Gough, Lord, 21 et seq., 51, 83, 93, 97, 98 .

Gough, Sir Charles, 240, 244, 313, 329,342 et seq., 351 .

Gough, Sir Hugh, 224, 231, 240, $244,255,257,260,269,271$, $272,277,278,285,302,308$, $313,315,318,319,327,329$, $330,341,346$.

Govindgarh, 79.

Grant, Sir Hope, 202, 203, 209, 21S, 222, 257, 259, 260, 262, $264,285,302,324,325$.

Grant, Sir Patrick, 214. 
Greathed, Colonel, 277, 283.

Greathed, Hervey, 209, 222, 236, $245,247,253,263$.

Greville, - , 203, 225, 261.

Guernsey, 18, 129.

"Guides," the, 57, 58, 68, 69, 75, 100 -Hodson in command, 131 et seq. - removed from command, 156 -court of inquiry, 157 et seq., 172, 198, 206-Hodson takes temporary command, 214, 220, $226,230-237$.

Gulâb Singh, 35, 46, 47, 7S, 115 .

Halifax, Brigadier, 200.

Hardinge, Lord, 21, 28, 35, 36, 50, 139 , is6.

Hariki, 31.

Haripur, 134.

Harland, Charles, 316.

Harland, Rev. E., 3, 126.

Havelock, General, 236, 252, 277.

Hawes, - 224.

Hela, 92.

Herbert, Lieutenant, 93.

"Hodson's Horse," 191, 192, 197, 198, 219, 221, 224, 236, 237, 251, 289, 291 et passim, 346.

Hodson, Rev. G. H., "Hodson of Hodson's Horse" quoted, 2 et passim.

Hodson, IVilliam Stephen Raikes, birth and parentage, 1-early training, 3-at Rugby School, 3 et seq. - Trinity College, Cambridge, 15 et seq.- commission in the Guernsey Militia, 1S-cadet in the East India Company's service, 19-Madras and Calcutta, 20-Agra, 21-appointed to 2nd Bengal Grenadiers, ib. - Delhi, 22-Umbâla, 24-First Sikh war, 25 et seq.--exchanges into 16 th Grenadiers, 32-Lahore, 33exchanges into 26th Sepoys, 36 - the march to Umbâla, 37eriticisms on the conduct of the war, 38 et seq. - his estimate of the native army, 4l-joins lst Bengal Fusiliers at Sabâtha, 42 - beginning of friendship with Henry Lawrence, 43-acconpanies Lawrence to Kashmir, 46 et seq.- -secretary to Lawrence Asylum, 53 et seq. - appointed to the Guides, 58 - on the staff of the Resident at Lahore, 59, 66 -after the Mnltân outbreak, 67 et seq. -Second Sikh war, 77 et seq. - Assistant Commissioner in the Punjâb, 101 et seq. - a trip to Kashmir, 113 et seq. - lis purchase of shawls, 119 et seq.Assistant Commissioner, CisSatlaj states, 122-marriage, 129 -in command of the "Guides," 131 et seq. - enmity towards him, 151 et seq. - the Khadar Khan incident, 155 et seq. - the conrt of inquiry, 157 et serq. - finding of the court, 163--Najor Reynell Taylor's investigations, 164 et seq. - the accounts declared satisfactory, 166-further public inquiry not allowed, 168 et seq.return to the 1st Bengal Fusiliers, 174-Colonel Welchman's appeal, 181-beginning of the hunting, 190-assistant quartermaster-general and Intelligence Officer to Ansou's force, 191empowered to raise 1000 irregular horse, $i b$. - daring ride to Meernt, 192-recrniting for "Hodson's Horse," 197 et seq.-— before Delhi, 201 et seq. -assists in preparing plan for carrying Delhi, 209ronts the rebels at Rohtak, 239 et seq.-Basharat Ali shot, 248 et seq.-storming of Delhi, 254 et seq. - captures the King of Delhi, 264 et seq. - seizes and executes the three Shahzîdas, 267 et seq. - the prize - money calumny, 278 et seq. - with Brigadier Showers, 280 et seq. - charge of looting refuted, 286 et seq.accompanies Seaton's column to Fathigarh, 291 et seq. - action at Gangêri, 294 et seq. - at Patiâli, 296 et seq. - at Mainpûri, 299the Miran-ke-Serai expedition, 301 et seq.--joins Sir Colin Campbell, $30 \mathrm{~s}$ - fighting at Shamsabad, 312-Cawnpore, 315 et seq. - "Hodson's Horse" in 
action, 318 et seq. - Lucknow, 323 et seq.-mortally wounded, 332 - the last scene, 337-tributes to his memory, 340 et seq., 347 et seq., 389-slanderous attacks, 343 et seq., 351 et seq., $387 n$.

Hope, Captain Adrian, 309, 311.

Hudson, Mr, 295.

Hughes, Tom, 11, 12.

Hutchinson, General, 331.

Imâm-ud-din, Shaikh, 46, 48, 197.

Inglis, Sir Robert, 19.

Innes's 'History of the Bengal European Regiments' quoted, 295.

Ireland, Dr, 251.

Iskardo, 114, 117.

Isri Singh, Risaldâr, 248.

Jacob, Major, 224, 225, 261.

Jalâli, 293.

Jalandhar Doâb, 35, 81 .

Jhajar, Nawâb of, 283.

Johnstone, Brigadier-General, 182.

Jowâhir Khan, 298.

Kalallwâla, $S \pm$ et seq.

Kalsi, 115.

Kanaud, 284, 285.

Kanh Singh Rosah, 197.

Kargil, 114.

Karnâl, 191 et seq., 195, 196, 200.

Kashmir, 35, 46 et seq., 113 et seq., 119 et seq.

Kassûr, 33, 59, 61 .

Keith-Young, Colonel, 292.

Khadar Khan imprisoned by Hodson, 155-acquitted by the Commissioner, $156-172,174$.

Kharkauda, 239, 248.

Khasganj, 296, 298.

Khudâ Baksh, 155.

Knox, Captain, 210.

Kussowlie, 121, 124, 130, 191.

Ladâkh, 114.

Lahore, 25, 33, 50, 59, 65, 66, 75, $77,79,80,95,103,106,123$, 174.

'Lahore Chronicle' quoted, 200.

Lake, Lieutenant, 77, 98.
Lâl Singh, 35, 50.

Larsauli, 200.

Lawrence Asylum, the, 52 et seq., 125.

Lawrence, Captain Richard, 180, $252,256$.

Lawrence, Major George, 74, 77, 80.

Lawrence, Sir Henry, 31, 36, 43, $44,46,50,52,54,58$ et seq., s9 n., 95, 101 et seq., 106, 107, 113 et seq., 118, 119, 122, 135, 139, 154, 184, 201, 234, 276.

Lawrence, Sir John, 102, 139, 143, 150 et seq., 157, 162 et seq., 169, 342.

Leh, 116.

Light, Alfred, 203.

Light, Major, 294.

Littler, General, 27, 35.

Llamas, the, 117.

Longa Mal, 72.

Longfield, Brigadier, 221.

Lucknow, 277, 316, 323 et seq.

Ludiâna, 31, 33.

Lugard, Sir E., 317, 324, 326, 328, 332.

Lumsden, Lieut., 251.

Lumsden, Sir Harry, 58, 69, 93, 98, 101, 131, 133, 136, 153, 379.

Lushington, Mr Frederick, 128.

Lyell, Dr, 137, 161.

Macaulay, Lord, 160.

M'Dowell, Lient., 219, 221, 224, $231,242,244,246,263,267$, $269,271,281,284,301$ et seq., $306,312,313$.

Mackeson, Colonel, 134, 141, 155, 276.

Macpherson, Major, 157, 170.

Mactier, Dr, 229, 251.

Madras, 20.

Maharâj Singh, 70.

Mainpûri, 299.

Malleson, Colonel, $387 n$.

Mansfield, General, 302, 310, 344.

Mân Singh, Risaldâr, 255, 269.

Mardân, 144, 148, 165.

Marri, 140, 147, 148.

Marshall, Rev. J. Knox, 120.

Maunsell, —, 209. 
Meerut, 190, 192, 194, 286.

Michni, Fort, 173.

Miran-ke-Serai, 301, 306, 309.

Mitford, Major-General, 155, 173, $215,326$.

Montgomery, Sir Robert, 107, 119, $168,174,187,197,198,270$, 339.

Mudki, 26.

Muhammad Khan, Sultân, 80 .

Mulrâj, 65, 67, 72, 78, 79, 96.

Multân, 65 et seq., 77, 79, 92, 93, 96.

Mutiny, the, 190 et seq.-outbreak at Meerut, 190-the mutineers seize Delhi, 191-before Delhi, 201 et seq.- - storming of Delhi, 254 et seq. - siege of Lucknow, 327 et seq.

Najaf Ali, 165.

Najafgarh, 247, 251.

Napier, Lord, 62, 119, 135, 162, $168,171,176$ et seq., 287, 292, $300,302,315,317,331,336$ et seq., 340, 342, 344, 351, 352.

Napier, Sir Charles, 37, 69, 106, $110,121,139$.

Napier, Sir IVilliam, 18.

Neill, General, 277.

Nicholson, Colonel John, 77, 80, $92,150,160,216,236,239$, $246,247,251,252,254$ et seq., 260 et seq., 266, 276.

Nihâl Singh, 155, 334, 335, 338.

Norman, Sir Henry, 214, 221, 227, 233, 248, 300, 302.

Outram, Sir James, 150, 277, 300, $318,321,324,327,328,352$.

Owen, —, 261.

Pakli, 134.

Pâlamau, 309.

Pathankôt, 107.

Patiâli, 130, 296.

Peel, Captain, 316, 327.

Peel, Sir Lawrence, 21, 129, 130.

Penny, General, 286, 291.

Perkins, Mr H. C., 345.

Peshâwar, 92, 100, 133, 136, 149, 15s, $173,197$.

Philôr, 33, 201.
Pir Panjal Pass, $4 \mathrm{~S}$.

Probyn, Lient., 259.

Punjâb, treaty of peace, 35-treaty of Bhairowal, 50-annexation, 99 .

Radetzky, - 110.

Rai, 201.

Raikes, Mr Charles, 174.

Rajab Ali, 197, 217, 265, 267.

Râmnagar, 80, 83 .

Ram Singh, 94, 95.

Rangar Nagal, 81, 82.

Ranjor Singh, 31.

Rasûl, 96.

Ravi river, 62, 64, 70, 83, 85, 94.

Rawal Pindi, 99, 131.

Reed, General, 227.

Reid, Sir Charles, 257.

Rewâri, 282.

Roberts, Lord, 220, 225, $271343 n$.

Rohtak, 239, 241 et seq.

Rotton, Rev. J. E., 235.

Rulgby School, 3 et seq.

Rupar, 46.

Russell, Captain, 204.

Russell, Sir William, 'My Diary' in India' quoted, 327.

Sabâthu, 42, 46, 191.

Sabzi Mandi, the, 211, 228, 229.

Salkeld, - , 211, 212.

Sanâwar, 52.

Sanford, Captain, 259.

Satlaj, 26, 29, 31, 33, 36, 46, 72, 125.

Saunders, Mr Charles B., 103, 107, 266.

Seaton, Sir Thomas, 199, 20S, 210, $214,216,217,223,229,230$, $261,270,274 n ., 277,278,291$, 294 et seq., 305, 307, 308, 311, 313,341 .

Seniority system, the, 10S, 109.

Seton-Karr, Mr W. S., 4, 129.

Shahdara, 83.

Shahzâdas, capture and execution of the, 267-275.

Shamsabad, 311, 312.

Shamsher Singh, 65, 197.

Shebbeare, of the Guides, 219, 224.

Sherer, Mr John Walter, 7.

Sher Singh, 79, 92. 
Showers, Brigadier, 224, 229, 238, $278,280,282,283,286$.

Sikh War, the First, 21 et seq.Mudki, 26-Firozshah, 27-Aliwâl, 31-Sobraon, 32-end of the war, 33-the treaty, 35, 36 -Hodson's criticisms of the campaign, $3 \mathrm{~S}$.

Sikh War, the Second, 77 et seq.capture of Govindgarh, 79-Rangar Nagal taken, 81 - Kalallwâla, 84 et seq.-Baddi - Pind, S8 et seq.-Miltân surrenders, 93, 96-Chilianwala, 93-victory of Gujarât, 97, 98-annexation of the Punjâb, 99.

Simla, 43, 118, 121, 131, 186, 191.

Singh Mân, 78.

Sloggett, Rev. C., 158, 159, 186 , $189,279,287,345,352$ et seq.

Simith, Professor Bosworth, $387 n$.

Smith, Sir Harry, 31.

Sobraon, 31, 32, 34 n., 39.

Sonpat, 245.

Stanley, Lord, 34S.

Stewart, Sir Donald, 287, $343 \mu$.

Sultanpur, 29.

Sumalka, 200.

Suraj Ghat, 312.

Talbot, Mr, 285.

Taylor, General Sir Alexander, 332.

Taylor, Major Reynell, s0, 161directed to examine Hodson's accomnts, 164-his detailed report, 166 et seq., 356 et seq.$171,175,177,185,187$.

Tej Singh, 29, 39, 47, 197.

Temple, Sir Richard, 152, 345.

Thána, 47, 48 .

Thomason, General C., 17, 193, Ynzafzai, 137 et seq., 140, 156. $195,203,211,212,246,275$.
Thomason, Lieut. -Governor James, $21,41,104,118,121,122,130$, $131,141,142$.

Tibet, 114 et seq.

'Times' newspaper quoted, 349.

Tombs, Captain F. C., 344.

Torquay, 19.

Tulsi Ram, 282.

Turner, Lieut., 133, 152, 157, $158,163,165$.

Umbâla, 24, 36, 40, 130, 174, 182, $185,191,192,286,287,290$.

Unao, $315,317$.

Vyse, Mr, 295.

Walpole, Brigadier, 305, 310.

Ward, Captain George, 220, 241, 244.

Wardlaw, Captain, 294, 295.

Watson, Lieut., 259, 309.

Wazirabad, 97.

Welchman, Colonel, 176, 17S, 181 et seq., 216, 227.

IVells, Lieut., 284.

Wheeler, Sir Hugh, 81 et seq., 94, $108,236$.

Wheler, Colonel, 130.

Whish, General, 77, 79, 92, 96.

Wilkinson, Captain Osborn, 325, 329,338 .

Wilson, General Sir A., 193, 197, 201, 228 et seq., 234, 239, 245, $247,252,253,256,261,263$, $266,267,270,271,274,278$, $279,286$.

Wise, Lient., 220, 242, 244, 284.

IVriford, Major, 279.

Young, Colonel Keith, 189, 190.

Younghusband, Lieut., 259. 
Wobster Family Library of Veterinary Me Cumminas Schonl divetemary Medicin Tufts 10

200 we wero oad

North Graton, MA.01536

Wehs

$\mathrm{Cl}_{1}$ 
